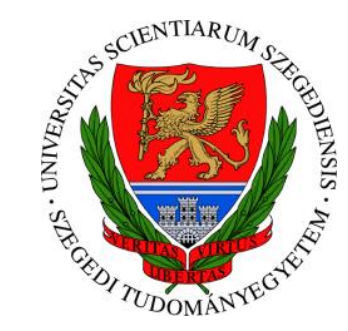

\title{
SZEGEDI TUDOMÁNYEGYETEM
}

Természettudományi és Informatikai Kar

Fizikai Kémiai és Anyagtudományi Tanszék

Doktori értekezés

\section{Oxid alapú összetett fotoelektródok előállítása és vizsgálata}

Varga András Márk

TÉMAVEZETŐ:

Dr. Janáky Csaba

egyetemi adjunktus

Szeged

2019 


\section{Tartalomjegyzék}

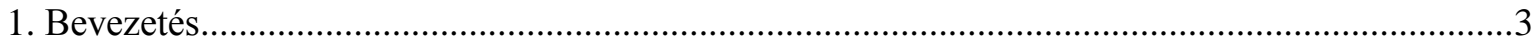

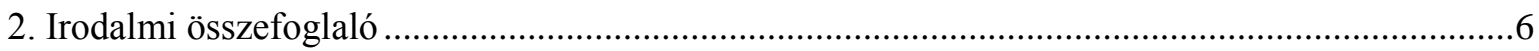

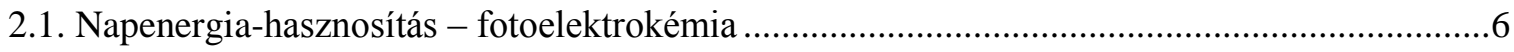

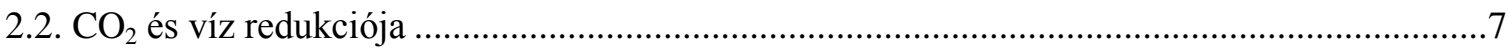

2.3. Fotoelektródokról általában, különös tekintettel a fotokatódokra ............................................

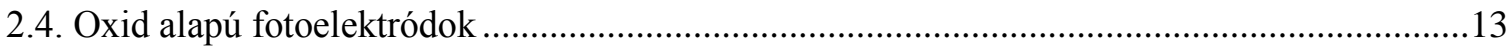

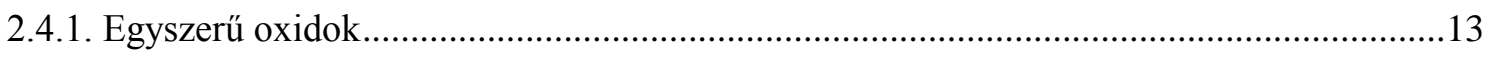

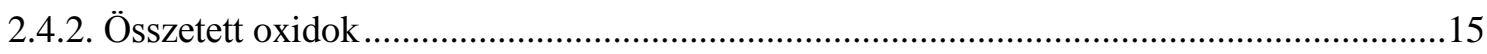

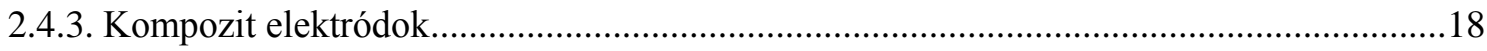

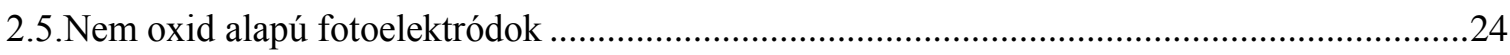

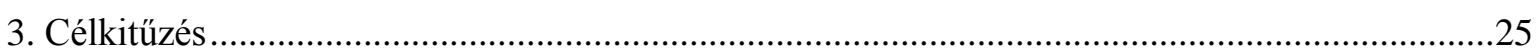

4. Kísérleti módszerek és alkalmazott technikák ……............................................................26

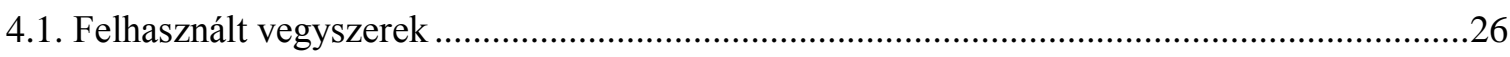

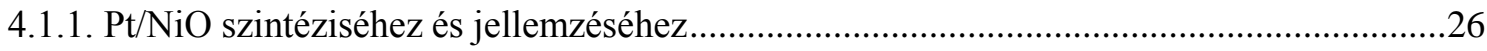

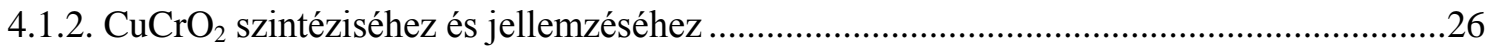

4.1.3. Kétfázisú és ötvözet delafosszitok szintéziséhez és jellemzéséhez....................................26

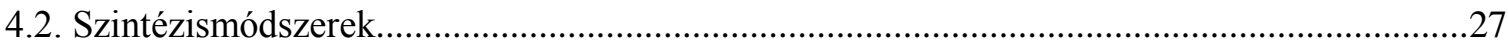

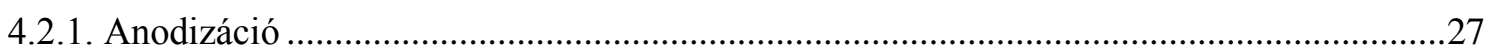

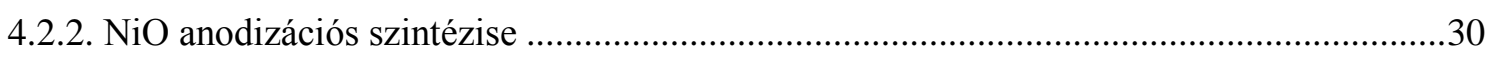

4.2.3. Pt nanorészecskék előállítása a $\mathrm{Pt} / \mathrm{NiO}$ rétegekhez ........................................................... 30

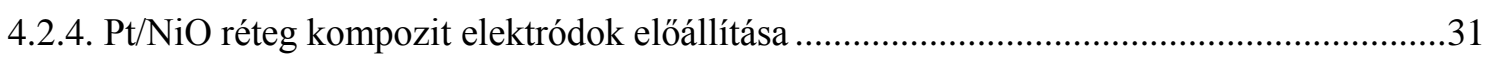

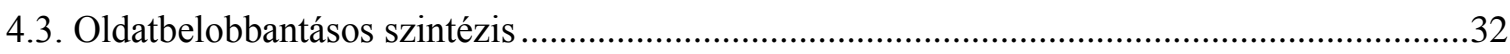

4.3.1. $\mathrm{CuCrO}_{2}$ elóállítása oldat belobbantásos szintézissel ..........................................................

4.3.2. $\mathrm{A} \mathrm{CuFeO}_{2}$, ötvözetek és kétfázisú delafosszit kompozitok elektródok kialakítása..............37

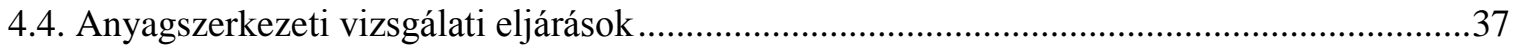

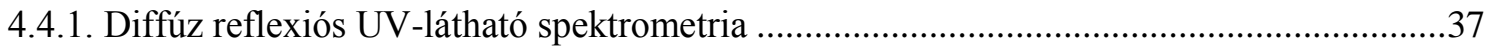

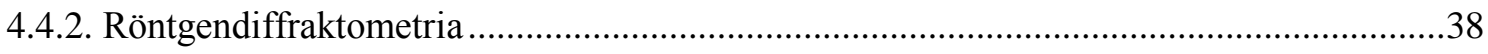

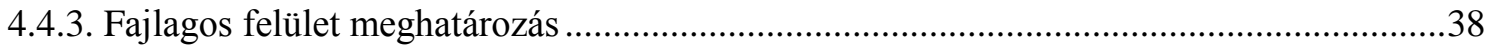

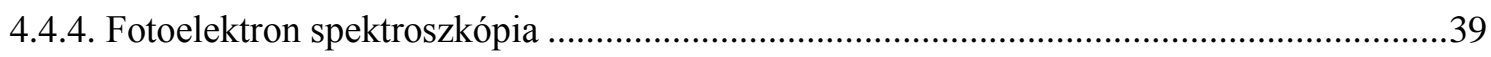

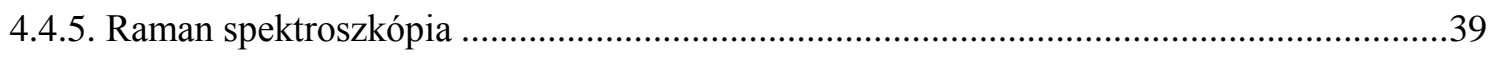

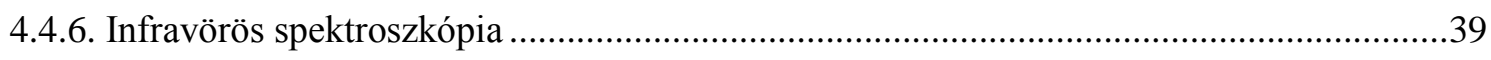

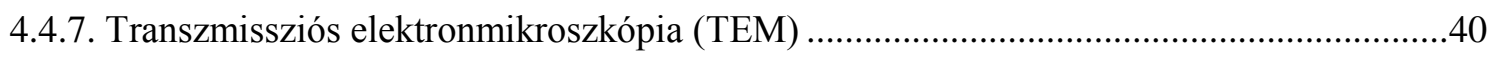

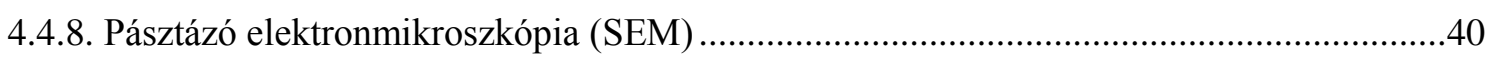

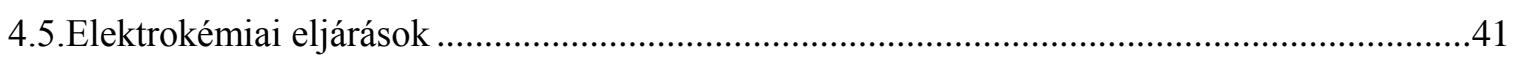




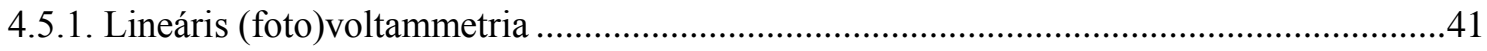

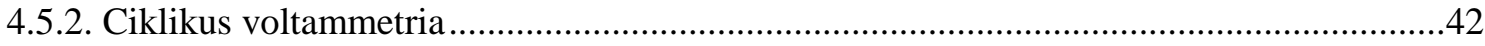

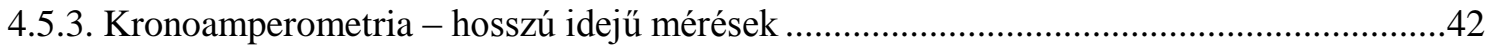

4.5.4. Elektrokémiai impedancia spektroszkópiás (EIS) mérések …….........................................43

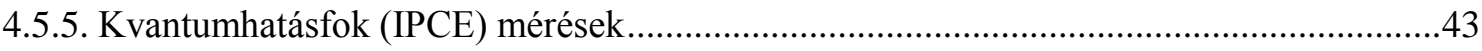

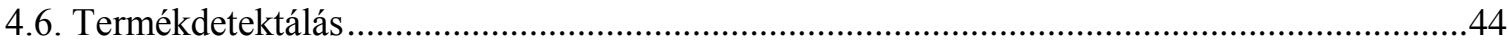

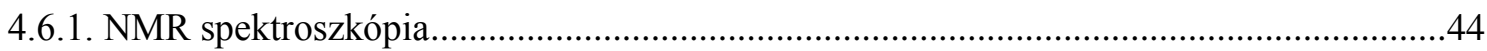

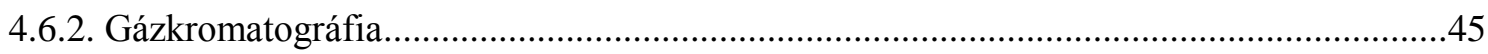

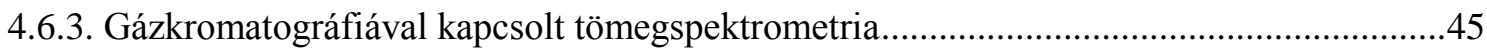

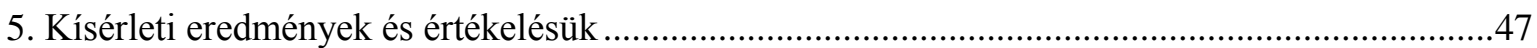

5.1. $\mathrm{NiO}$ és $\mathrm{Pt} / \mathrm{NiO}$ kompozit fotokatód előállítása és jellemzése …................................................47

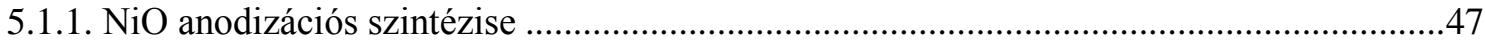

5.1.2. Az alkalmazott anodizációs módszerek összehasonlítása .................................................47

5.1.3. Az optimalizált anodizációs körülmények között készült NiO rétegek morfológiai és

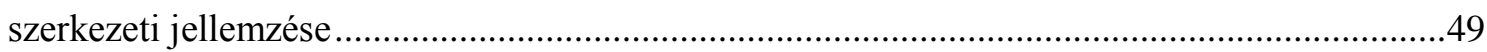

5.1.4. A NiO rétegek elektrokémiai és fotoelektrokémiai jellemzése ..........................................52

5.1.5. Pt/NiO morfológiai és elektrokémiai jellemzése ……………...........................................54

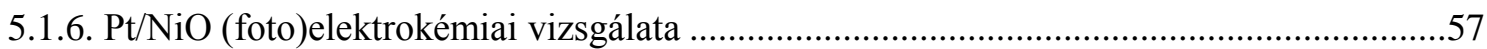

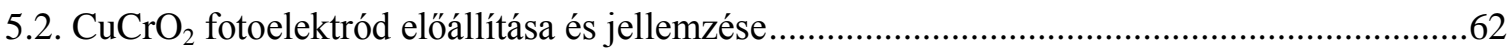

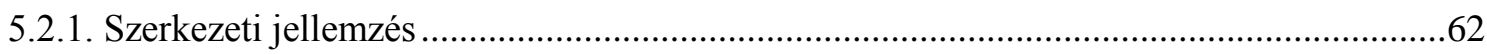

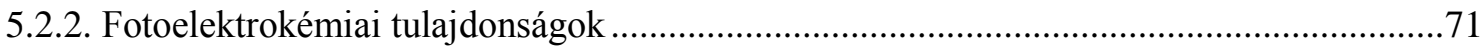

5.2.3. $\mathrm{A} \mathrm{CO}_{2}$ hosszú időtartamú fotoelektrolizise és termékek azonosítása ................................76

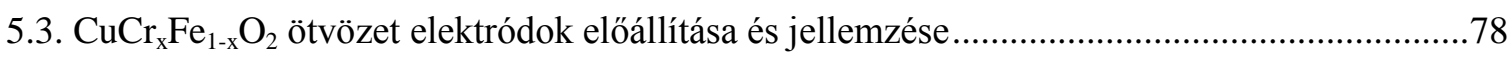

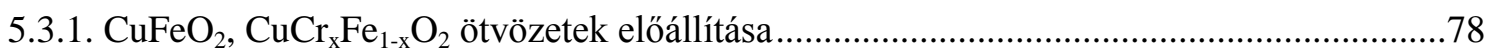

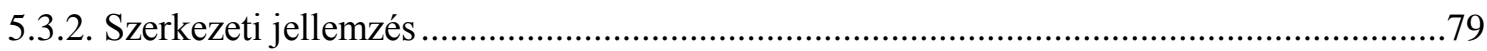

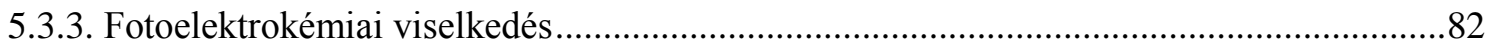

5.4. $\mathrm{CuCrO}_{2}$ és $\mathrm{CuFeO}_{2}$ kétfázisú elektródok elóállítása és jellemzése........................................82

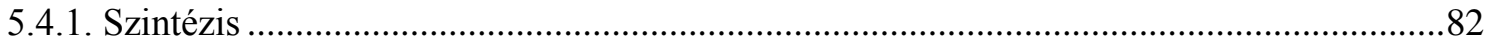

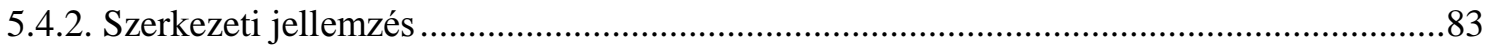

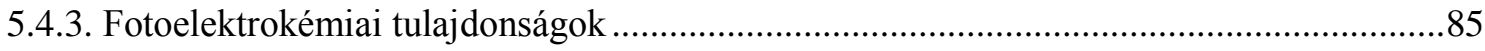

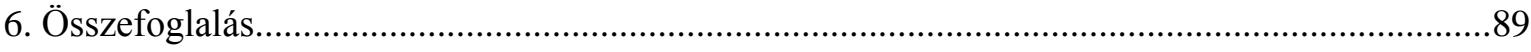

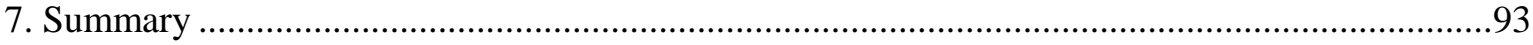

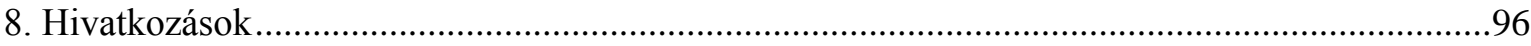

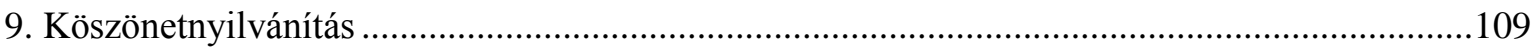




\section{Bevezetés}

A szén-dioxid a szénhidrogének oxidációjának fő terméke. Mivel a szénhidrogén alapú üzemanyagok a világ legfontosabb energiaforrásai, ezért a fosszilis üzemanyagok használata jelentősen növelte a $\mathrm{CO}_{2}$ koncentrációját a légkörben. Jól mutatja a $\mathrm{CO}_{2}$ feldúsulásának egyik hatását, hogy a levegő $\mathrm{CO}_{2}$ koncentrációjának növekedésével együtt a Föld átlaghőmérséklete is majdnem 1 Celsius fokkal emelkedett, alig 100 év alatt [1]. Egyre nagyobb ezért az igény olyan energiahordozók használatára, amelyek nem szennyezik környezetünket - vagy pedig a már légkörben található szén-dioxidból energiahordozókat előállítva, majd azokat energiatermelésre használva szorítják vissza légköri szén-dioxid koncentráció további növekedését.

Egy másik perspektívából nézve, a légköri $\mathrm{CO}_{2}$ egy lehetséges nyersanyagforrás, amely kiválthatja a kőolaj alapú szénhidrogénforrásokat. $\mathrm{A} \mathrm{CO}_{2}$ átalakításából származó szénhidrogéneket energiahordozóként alkalmazva egy mesterséges $\mathrm{CO}_{2}$ ciklus kialakítása válna lehetővé anélkül, hogy több $\mathrm{CO}_{2}$ kerülne a légkörbe. Ennek a mesterséges szénciklusnak legnagyobb előnye az lenne más, még használt energiaciklusokkal szemben, hogy a tárolásuk sokkal gazdaságosabb lenne, mivel a szénhidrogének tárolására kész infrastruktúra áll rendelkezésre [2].

Számos módszer ismert a $\mathrm{CO}_{2}$ redukciójára. Vannak alacsony hőmérsékletü, enzimekkel elősegített módszerek, mint pl. a Calvin ciklus [3]. Ismertek hagyományos kémiai módszerek is. Ezek közül fontos megemlíteni a Sabatier-eljárást, illetve vannak még egyéb, nagy hőmérsékleten és nyomáson lejátszódó folyamatok, melyek terméke többek között: karbamid, karbonsavak, polikarbonátok, vagy metanol [4].

Ezekkel a rendkívül energiaigényes módszerekkel szemben az utóbbi időben egyre inkább előtérbe kerülnek a $\mathrm{CO}_{2}$ hasznosításában az elektrokémiai eljárások [5]. Ezek közül is előreláthatólag a napenergiát felhasználó módszereknek lesz kiemelkedő szerepük. A napenergia az egyik legtisztább, és gyakorlatilag kimeríthetetlen energiaforrás: egy óra alatt körülbelül a Napból a Földre érkező energia mennyisége meghaladja az emberiség egy évi energiaigényét [6]. Problémát a napenergia megfelelő hatásfokú átalakítása, tárolása, valamint a jelenleg használatos technológiák magas ára jelenti. Számos kutató köztük Oláh György, magyar származású Nobel díjas kutató - rámutatott arra, hogy akár egy, a metanolon alapuló energiagazdaság is fenntartható lenne [7]. Éppen ezért kiemelt szerepe van azoknak a $\mathrm{CO}_{2}$ redukciós eljárásoknak, melyek terméke a metanol. A metanol mint alapanyag számos esetben - például kőolajszármazékok előállítására, illetve 
tüzelőanyag cellákban is - felhasználható lenne. Ezen felül a kutatások másik fő nyomvonalát a $\mathrm{H}_{2}$ előállítása adja (például fotoelektrokémiai módszerekkel), mivel azonos tömeg esetén nagyobb az energiasürüsége, mint a szénhidrogéneknek, és elégetésekor nem keletkeznek környezetre káros anyagok [8].

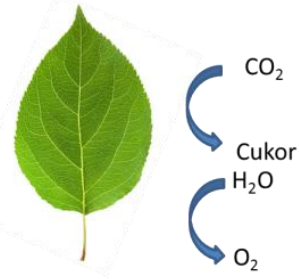

Fotoszintézis

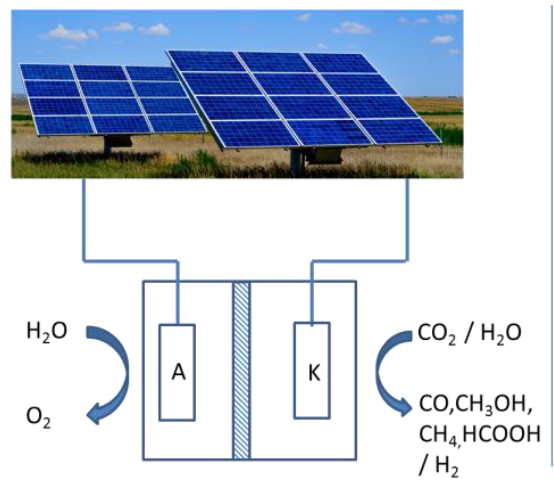

Elektrolízis

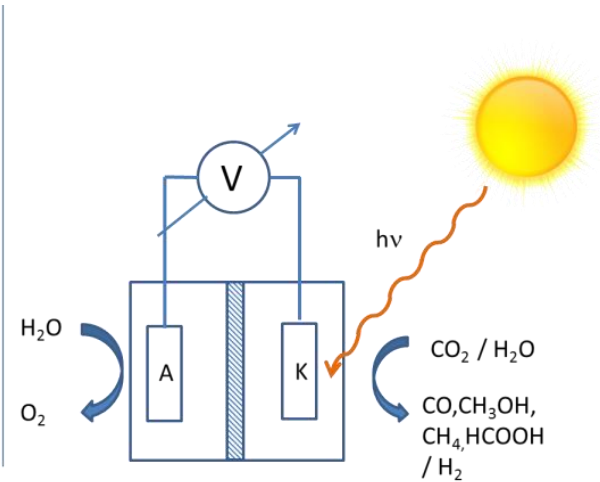

Víz és $\mathrm{CO}_{2}$ redukció félvezető felszínén

1. ábra: A szén-dioxid és a víz redukciójának lehetséges módszerei.

A tüzelöanyagok (olyan anyagok, amelyek kémiai kötéseikben nagy mennyiségü energiát tárolnak) napenergia segítségével történő előállítására jelenleg három fő módszer ismert: a fotokémiai, a napelemek (fotovoltaikus elven müködő berendezések) által termelt villamos energia segítségével végrehajtott és a fotoelektrokémiai módszerek.

Ezek közül a fotokémiai $\mathrm{CO}_{2}$-redukciót tulajdonképpen mesterséges fotoszintézisnek is tekinthetjük. Ennek során, hasonlóan a természetes folyamathoz, egy fotoaktív anyag fény hatására nagy energiatartalmú termékekké redukálja a $\mathrm{CO}_{2}$-ot, miközben a napenergia a kémiai kötések formájában tárolódik.

Ezen kívül lehetséges napelemek felhasználásával tüzelőanyagokat előállítani, a napelemek által megtermelt villamosenergiát a megfelelő elektrokémiai cellában felhasználva a $\mathrm{CO}_{2}$ vagy víz redukciójára (1. ábra). Ez egy technológiai szempontból is vonzó megoldás, mivel a modern napelemek egyre nagyobb hatékonysággal és élettartammal müködnek.

További megoldás lehet, ha a napenergiát nem a napelemeknél megismert módon hasznosítjuk, hanem közvetlenül egy elektród felszínén (1. ábra), egy elektrolit oldatban redukáljuk a szén-dioxidot vagy a vizet a fotogenerált elektronok segítségével. Ehhez ki kell alakítanunk egy olyan félvezető/elektrolit határfelületet, amely alkalmas arra, hogy a napfény hatására töltésszeparáció következzen be, és a redoxi reakció végbemenjen rajta. Megfelelő hullámhosszúságú fény hatására a p-típusú félvezető katód anyagában keletkező elektronok közvetlenül redukálják a $\mathrm{CO}_{2}$-t vagy a vizet, és ezzel párhuzamosan az anódon 
a víz oxidációja megy végbe (a fotogenerált lyukak által). Ahhoz, hogy sikeresen végbemehessen a fotoelektrokémiai redukció, fontos a megfelelő félvezető anyagok megtalálása, amelyek segítségével nagy hatásfokkal, kis energia-befektetéssel, a kívánt terméket nagy szelektivitással vagyunk képesek előállítani (a szelektivitás a $\mathrm{CO}_{2}$ redukció esetén a párhuzamos reakciók miatt fontos).

Tüzelőanyagok közvetlen előállítása során számos anyagot vizsgáltak már, mint például a $\mathrm{Cu}_{2} \mathrm{O}, \mathrm{p}-\mathrm{Si}, \mathrm{FeS}_{2}, \mathrm{GaAs}, \mathrm{InP}$ [9-13]. Azonban ezen anyagok egyike sem tudta beváltani a hozzá füzött reményeket. Míg például a $\mathrm{Cu}_{2} \mathrm{O}$ jó hatásfokkal volt képes redukálni a $\mathrm{CO}_{2}$-t, a hosszú távú stabilitása nem bizonyult megfelelőnek [14,15].

Emiatt napjainkban egyre nagyobb szerepet kapnak az olyan megközelítések, ahol nem egyetlen anyaggal kívánják megoldani a feladatot, hanem két vagy több anyag kombinálásával alakítanak ki fotoelektródokat. Számos megoldás van már arra, hogy különbözö fém-oxidokat kombináljanak egy szerkezetbe [16], illetve kettő vagy több határfelületet alakítsanak ki a félvezetőkből [17]. Ennek hatására számos esetben tapasztaltak már nagyobb stabilitást, illetve a fotoelektrokémiai sajátságok javulását. 


\section{Irodalmi összefoglaló}

\subsection{Napenergia-hasznosítás - fotoelektrokémia}

Az előzőekben említett, napenergiát hasznosító módszerek közül a kutatások egyik nyomvonalát az energiahordozók fotoelektrokémiai cellákban való előállítása adja. A fotoelektrokémiai cellák egy elektrolit oldatba merülő félvezető munkaelektródból és egy (fém vagy félvezető) ellenelektródból állnak. Amennyiben a szerves vagy szervetlen félvezető elektródot megfelelő hullámhosszúságú fénnyel világítjuk meg, akkor az így keletkezett töltéshordozók az oldatban lévő elektroaktív anyag oxidációját és/vagy redukcióját idézhetik elő. Azt, hogy a félvezető milyen hullámhossztartományban aktív, a tiltott sáv szélessége, azaz a vegyértéksáv (legnagyobb energiájú betöltött pálya) és a vezetési sáv (legalacsonyabb energiájú be nem töltött pálya) közötti energiakülönbség szabja meg.

A félvezető anyagok között attól függően, hogy mi a többségi töltéshordozó - negatív töltésű elektron, vagy pozitív töltésű (elektron-)lyuk - megkülönböztetünk n- és p-típusú félvezetőket. Az n-típusú félvezetőkben a vezetési sávhoz közel eső energiájú donornívók találhatóak, ahonnan a vezetési sávba viszonylag kis energiabefektetés hatására az elektromos vezetést biztosító elektronok kerülhetnek. A p-típusú félvezetőkben a vegyértéksávhoz közel akceptor energianívók helyezkednek el, ahova a vegyértéksávból az elektronok ugyancsak viszonylag kis energia hatására is át tudnak kerülni. A p-típusú anyagokban a visszamaradó pozitív töltésü lyukak elmozdulása alakítja ki a vezetést.

Ha egy szilárd félvezető elektrolit oldattal érintkezik, a két fázis eltérő (elektro)kémiai potenciálja a félvezető sávszerkezetének megváltozását okozza a felületi rétegben (kiürülési réteg alakul ki). Amikor a félvezető az elektrolitba merül, akkor általában a Fermi szintje (olyan energiaszint, amelyen a töltéshordozók 50\%-os valószínüséggel megtalálhatóak) és az oldatban található redoxi-aktív anyag redoxi potenciálja nincsenek egyensúlyban. Azért, hogy a Gibbs energiák kiegyenlítődjenek a félvezetőben és a folyadékfázisban, a többségi töltéshordozók az oldatba áramlanak félvezetőből. Ennek hatására a félvezető Fermi szintje és a folyadékfázisban található anyag redoxi potenciája kiegyenlítődik. Ez által a p-típusú anyagok esetében az oldat töltése pozitív, míg a félvezető felülete negatív lesz. A megváltozott energiaviszonyok folytán elektromos tér alakul ki, és ennek következtében sávelhajlás következik be. Egy p-típusú félvezetőt tekintve ez azt jelenti, hogy az elektronok energiája a vezetési- vagy a vegyértéksávban, a félvezető tömbi fázisában nagyobb, mint a határfelületen (2. ábra). Ez a jelenség 
használható fel arra, hogy a p-típusú félvezetőket fotoelektrokémiai redukciós folyamatokban alkalmazzuk [18].

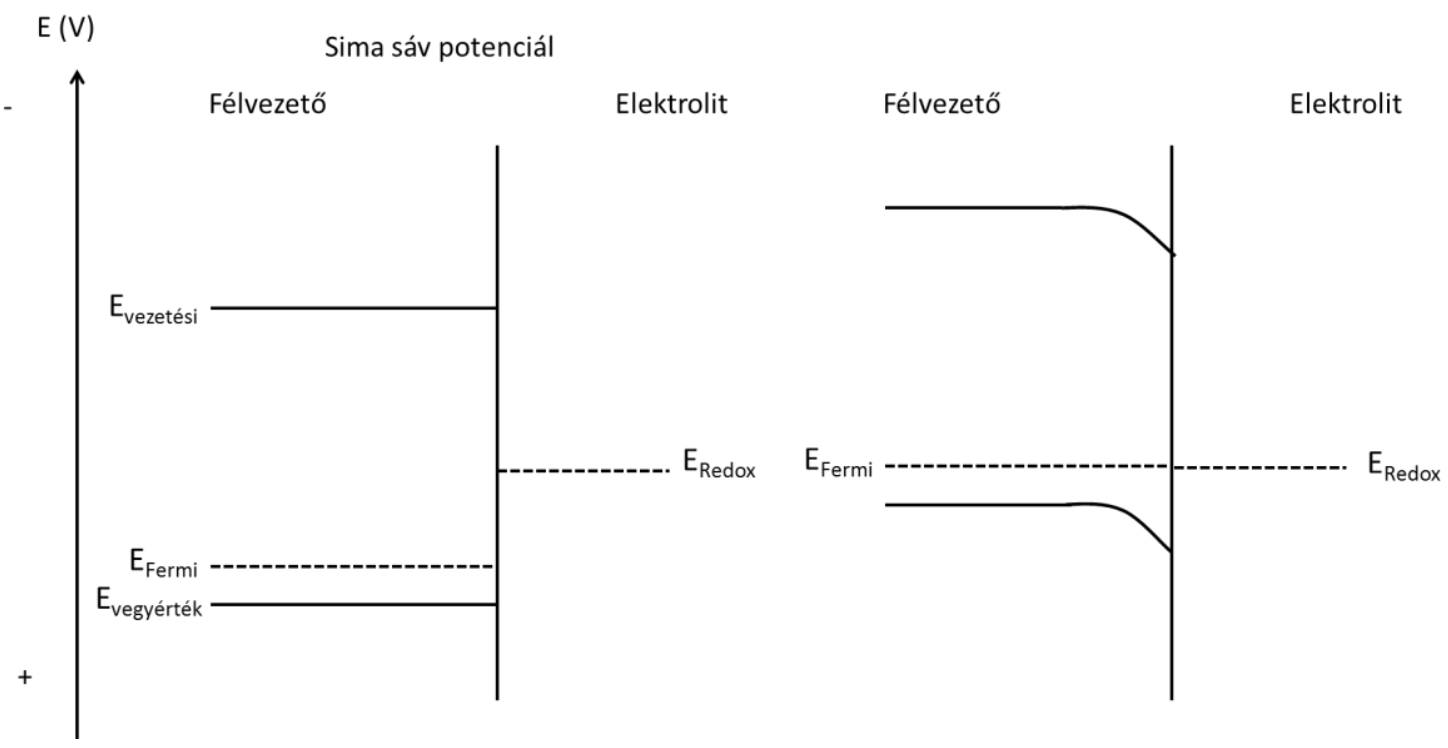

2. ábra: Egy p-típusú félvezető sávelhajlása, miután elektrolit oldattal került kapcsolatba.

Ha a félvezetőt olyan hullámhosszú fénnyel sugározzuk be, melynek energiája nagyobb, mint a tiltottsáv-szélessége, a vegyértéksávból elektronok lépnek át a vezetési sávba, elektron-lyuk párok jönnek létre. A p-típusú félvezetők esetén az elektrolit határfelületen kialakult energiaviszonyok miatt az elektronok a vezetési sávban az elektrolit felé mozdulnak, lehetőséget teremtve ezzel a felületen adszorbeálódott, vagy az oldatban található elektroaktív komponensek redukálására. A vezetési sávban visszamaradó lyukak vándorlása éppen ellenkező irányba, a tömbfázis belseje felé történik $[19,20]$.

A félvezetők fotoelektrokémiai tulajdonságainak jellemzésére gyakran használják a sima sáv potenciált. Ez az a külső potenciál, melynél nincs elektromos tér a félvezetőn belül, vagyis a határfelületen nem történik sávelhajlás. A sima sáv értékét többek között elektrokémiai impedancia spektroszkópiával lehet meghatározni (Mott-Schottky ábrázolás).

\section{2. $\mathrm{CO}_{2}$ és víz redukciója}

Ahhoz, hogy mind a víz, mind a szén-dioxid redukciója végbemehessen, számos feltételnek kell teljesülnie. A következőkben a legfontosabb jellemzőket tekintjük át. 
A víz bontása során két ellentétes folyamat megy végbe: az egyik a víz redukciója, a másik a víz oxidációja. Ennek a két folyamatnak a félcellareakcióit az alábbi módon tudjuk felírni (a potenciálokat a standard hidrogén elektróddal (SHE) szemben feltűntetve):

$$
\begin{array}{cc}
2 \mathrm{H}_{2} \mathrm{O} \rightarrow \mathrm{O}_{2}+4 \mathrm{H}^{+}+4 \mathrm{e}^{-} & \mathrm{E}_{\text {ox }}=1,23 \mathrm{~V} \\
4 \mathrm{H}^{+}+4 \mathrm{e}^{-} \rightarrow 2 \mathrm{H}_{2} & \mathrm{E}_{\text {red }}=0,0 \mathrm{~V}
\end{array}
$$

Ennek a két folyamatnak a végbemeneteléhez $237 \mathrm{~kJ} \mathrm{~mol}^{-1}$ energia szükséges, ami a Nernst-féle egyenlet alapján E = 1,23 V cellafeszültségnek felel meg. Ahhoz, hogy egy félvezetőn végbemehessen egy ilyen folyamat, ahhoz $1,23 \mathrm{eV}$ vagy nagyobb energiájú fotonnak kell elnyelődnie (ez 1000 nm-es vagy kisebb hullámhosszúságú fény elnyelését jelenti).

Mint látható, ebben a reakcióban négy elektronnak és lyuknak kell keletkeznie 2 mol $\mathrm{H}_{2}$ valamint $1 \mathrm{~mol} \mathrm{O}_{2}$ fejlődéséhez. Ideális esetben egy félvezetőn végbemehet mind a két folyamat, amennyiben nagyobb a tiltottsáv-szélessége, mint $1,23 \mathrm{eV}$, a vegyérték sáv pozitívabban helyezkedik el, mint az $\mathrm{O}^{2-} / \mathrm{O}_{2}$ redox pár, valamint a vezetési sávja negatívabban helyezkedik el, mint a $\mathrm{H}^{+} / \mathrm{H}_{2}$ redox potenciál.

A gyakorlat azt mutatja, hogy az ilyen esetekben még számolni kell a túlfeszültséggel, amely a rekombinációs helyekből származó veszteségből, valamint a két félreakció kinetikai gátoltságából fakad. A gyakorlati felhasználásban 1,6-2,4 eV közötti tiltottsávszélességgel rendelkező félvezetők lennének szükségesek, mivel ezek a fény nagy részét képesek volnának elnyelni, és elég nagy energiájúak lennének a keletkezett töltéshordozók. Azonban ilyen ,ideális” félvezetők jelenleg nem állnak rendelkezésre.

A

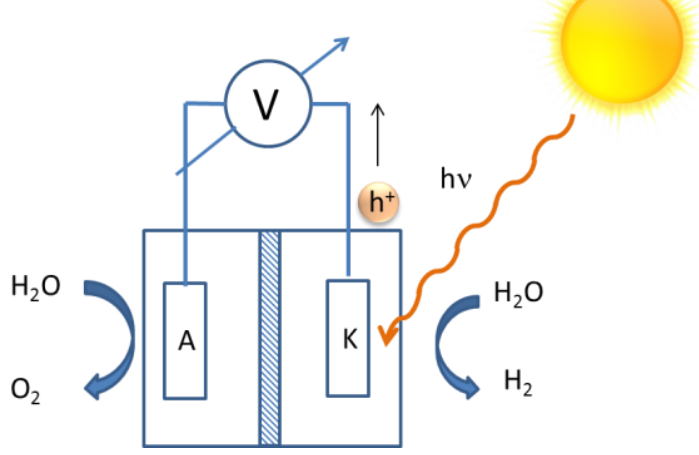

B

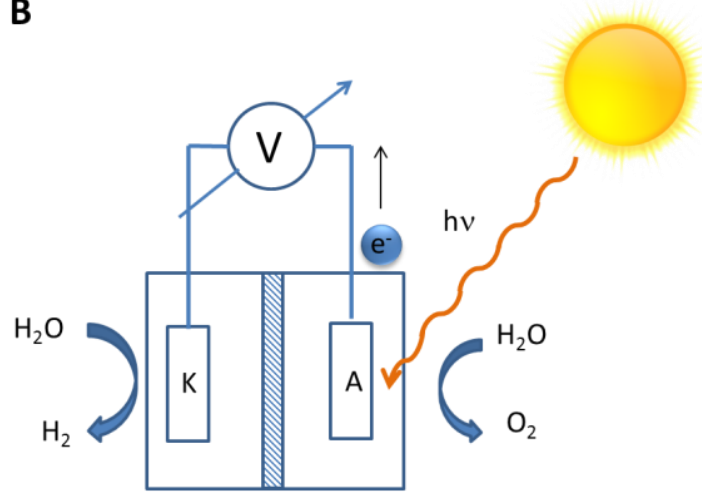

3. ábra (A) Egy p-típusú félvezető felszínén megvalósuló direkt fotoelektrokémiai vízredukció; (B) Egy n-típusú félvezető felszínén megvalósuló indirekt fotoelektrokémiai vízredukció

Gyakorlati alkalmazás során $\mathrm{H}_{2}$ fejleszthető közvetlenül egy p-típusú félvezető felületén (3. ábra A), vagy közvetve egy n-típusú félvezető segítségével (3. ábra B). A 
közvetett $\mathrm{H}_{2}$ fejlesztés során a megvilágítás hatására az n-típusú félvezetőn végbemegy az oxigénfejlödés. Az elektronok az áramkörön keresztül az ellenelektródra érkeznek, amelyen megtörténik a hidrogén-ionok redukciója [21].

A tüzelőanyagok előállításának egy másik fontos reakciója a szén-dioxid redukció. A szén-dioxid egy lineáris szerkezetü, nagyon stabil molekula. Ahhoz, hogy átalakítsuk, 394 $\mathrm{kJ} \mathrm{mol}^{-1}$ energiát kell befektetni. A redoxi potenciál értékek alapján azt lehet mondani, hogy a víz és szén-dioxid redukció mindig versenyben van egymással. Annak érdekében, hogy a $\mathrm{CO}_{2}$ redukciós folyamat minél gyorsabban és szelektívebben végbemenjen, gyakran katalizátorokat használnak. Az 1. táblázatban foglaltam össze néhány lehetséges $\mathrm{CO}_{2}$ redukciós reakció valamint a víz redukciós standardpotenciálját [20]:
Reakció
$\mathrm{E}(\mathrm{V})$

\begin{tabular}{lcc}
\hline $\mathrm{CO}_{2(\mathrm{~g})}+\mathrm{e}^{-} \rightarrow \mathrm{CO}_{2}{ }^{-}$ & $-1,850$ & $(3)$ \\
\hline $\mathrm{CO}_{2(\mathrm{~g})}+\mathrm{H}_{2} \mathrm{O}_{(\mathrm{l})}+2 \mathrm{e}^{-} \rightarrow \mathrm{HCOO}_{(\mathrm{aq})}^{-}+\mathrm{OH}_{(\mathrm{aq})}^{-}$ & $-0,665$ & $(4)$ \\
\hline $\mathrm{CO}_{2(\mathrm{~g})}+\mathrm{H}_{2} \mathrm{O}_{(\mathrm{l})}+2 \mathrm{e}^{-} \rightarrow \mathrm{CO}_{(\mathrm{g})}+2 \mathrm{OH}^{-}(\mathrm{aq})$ & $-0,521$ & $(5)$ \\
\hline $\mathrm{CO}_{2(\mathrm{~g})}+3 \mathrm{H}_{2} \mathrm{O}_{(\mathrm{l})}+4 \mathrm{e}^{-} \rightarrow \mathrm{HCOH}^{-}+4 \mathrm{OH}_{(\mathrm{aq})}^{-}$ & $-0,485$ & $(6)$ \\
\hline $2 \mathrm{H}_{2} \mathrm{O}_{(\mathrm{l})}+2 \mathrm{e}^{-} \rightarrow \mathrm{H}_{2}+2 \mathrm{OH}_{(\mathrm{aq})}^{-}$ & $-0,414$ & $(7)$ \\
\hline $\mathrm{CO}_{2(\mathrm{~g})}+5 \mathrm{H}_{2} \mathrm{O}_{(\mathrm{l})}+6 \mathrm{e}^{-} \rightarrow \mathrm{CH}_{3} \mathrm{OH}_{(\mathrm{l})}+6 \mathrm{OH}_{(\mathrm{aq})}^{-}$ & $-0,399$ & $(8)$ \\
\hline $\mathrm{CO}_{2(\mathrm{~g})}+6 \mathrm{H}_{2} \mathrm{O}_{(\mathrm{l})}+8 \mathrm{e}^{-} \rightarrow \mathrm{CH}_{4(\mathrm{~g})}+\mathrm{OH}_{(\mathrm{aq})}^{-}$ & $-0,246$ &
\end{tabular}

1. táblázat: $\mathrm{A} \mathrm{CO}_{2}$ és víz redukciós potenciál értékei vizes közegben $\mathrm{pH}=7$, vs. SHE [20].

A $\mathrm{CO}_{2}$ egyelektronos redukciója igen negatív potenciálon valósul meg, a molekula átalakulása a gyök anionná rendkívül energiaigényes folyamat. A többelektronos redukciós folyamatok azonban ehhez képest termodinamikailag kedvezöbb körülmények között játszódnak le. Ezen reakciók mindegyike az elektrontranszfer mellett protontranszfert is igényel, így elengedhetetlen protonforrást is biztosítani a reakcióhoz. Ez különösen fontos, amennyiben a reakciót nem vizes közegből hajtjuk végre. Ennek előnye a vizes közegü redukciókhoz képest, hogy a $\mathrm{CO}_{2}$ oldhatósága nagyobb lehet bizonyos nemvizes oldószerekben $[22,23]$.

A termodinamikai nehézségek mellett kinetikai akadályok is fellépnek az egyidejü protonátmenettel járó többelektronos redukciókban, hiszen minden egyes elektrontranszfer során le kell győzni egy aktiválási energiagátat is. További problémát jelent, hogy a $\mathrm{H}^{+} / \mathrm{H}_{2}$ redoxi rendszer standardpotenciálja nagyon közel esik a $\mathrm{CO}_{2}$ redukciós potenciálokhoz, 
ezért mindig számolni kell azzal, hogy a $\mathrm{CO}_{2}$ redukcióval egyidejüleg hidrogénfejlődés is végbemehet, a folyamat hatékonyságának rovására.

A $\mathrm{CO}_{2}$ redukciója megtörténhet közvetlenül a félvezetö/elektrolit határfelületen, ha a fény hatására a vezetési sávba kerülő elektronok képesek közvetlenül az oldatban lévő, illetve az elektród felületén adszorbeálódott $\mathrm{CO}_{2}$ molekulára jutni. Ugyanakkor a gyakorlati megvalósításban négyféle fotoelektrokémiai redukciós eljárást alkalmaznak, amelyeket a 4. ábra szemléltet.
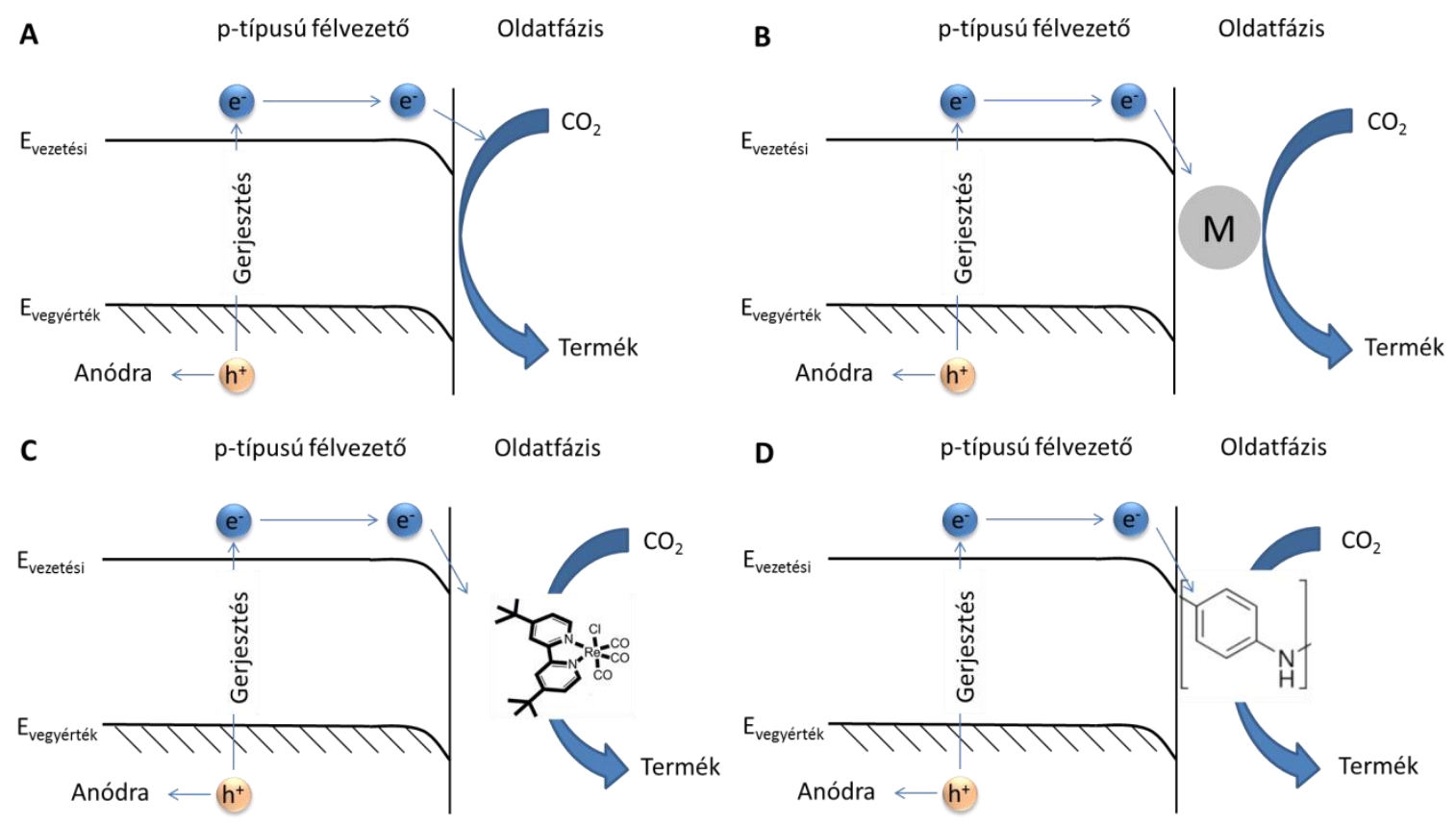

4. ábra: (A) $\mathrm{CO}_{2}$ redukció közvetlenül a félvezető/elektrolit határfelületen; (B) heterogén redukció egy p-típusú félvezetöhöz rögzített heterogén elektrokatalizátor részvételével; $(\mathrm{C}) \mathrm{CO}_{2}$ homogén redukciója egy olyan molekuláris katalizátor segítségével, mely a félvezető határfelületén redukálódott és ez alakítja át a $\mathrm{CO}_{2}$-t; (D) heterogén redukció a félvezető felületéhez kötött molekuláris katalizátor segítségével [4]

Annak érdekében, hogy minél jobb hatásfokú fotoelektrokémiai cellákat hozhassunk létre fontos, hogy minél jobban megértsük a $\mathrm{CO}_{2}$ redukció mechanizmusát. $\mathrm{Az}$ elektrokémiai redukció során a $\mathrm{CO}_{2}$ protont és elektront vesz át az elektród felszínén. $\mathrm{Az}$ bruttó reakció részlépései három nagyobb lépésben csoportosíthatók: (i) a $\mathrm{CO}_{2}$ adszorpciója az elektród felszínén, (ii) a $\mathrm{CO}_{2}$ felszíni diffúziója, a proton és elektron átlépése a $\mathrm{CO}_{2}$-re, (iii) a termékek távozása.

Amennyiben példaként a hangyasav képződésének mechanizmusát vizsgáljuk meg, akkor az első fontos lépés a $\mathrm{CO}_{2}$ adszorpciója a felületén. Az adszorpció során a $\mathrm{CO}_{2}$ és elektród között megosztott elektronok hatására a $\mathrm{C}=\mathrm{O}$ kötés erőssége megváltozik. Többféle feltételezett reakciómechanizmus is létezik. A leginkább elfogadott az, hogy az 
első lépésben egy semleges hidratált $\mathrm{CO}_{2}$ molekula alakul át egy $\mathrm{CO}_{2}{ }^{\circ}$ molekulává vizes közegben. Ezt követően az adszorbeált $\mathrm{CO}_{2}{ }^{\circ}$ reagál egy $\mathrm{H}_{2} \mathrm{O}$ molekulával és $\mathrm{HCO}_{2}{ }^{\bullet}$ fog keletkezni. Ezt követően a $\mathrm{HCO}_{2}{ }^{\circ}$ egy $\mathrm{HCO}_{2}{ }^{-}$molekulává fog átalakulni a nem stabil párosítatlan elektronjai miatt, majd az így keletkezett molekula deszorbeálódik a felszínről (5. ábra).

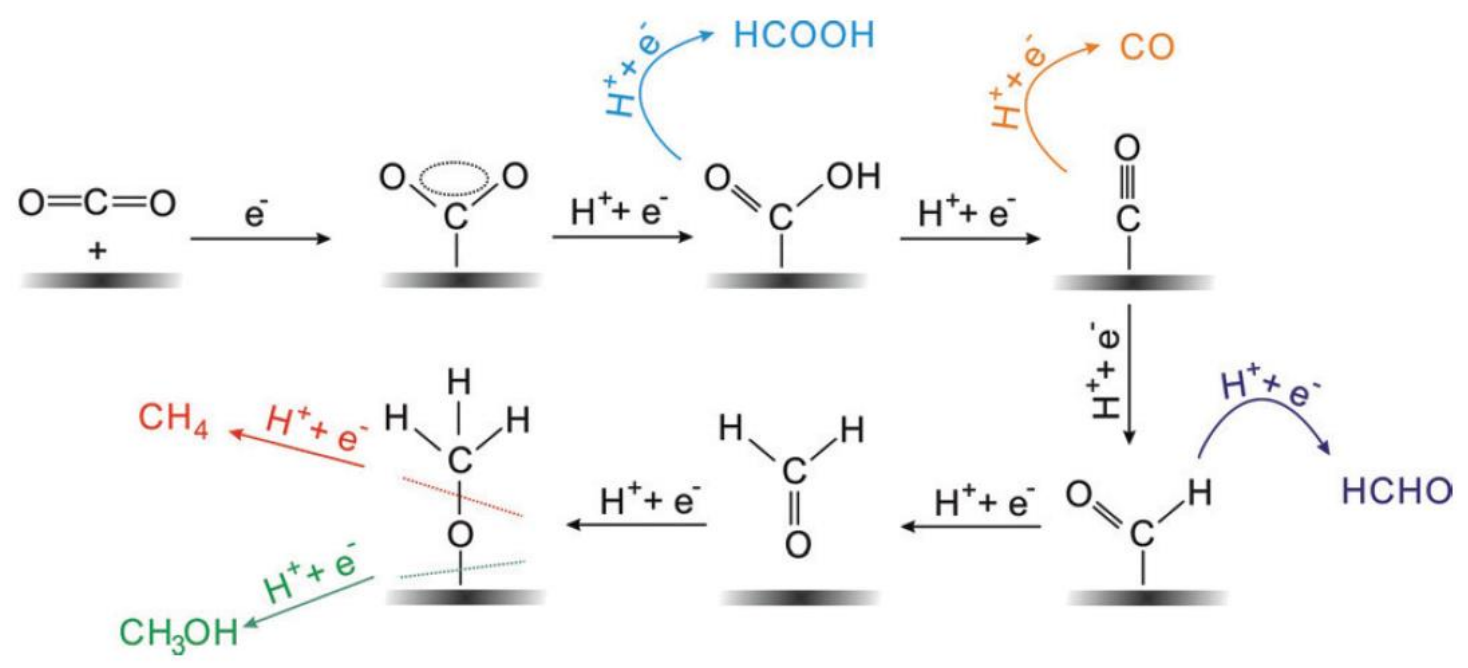

5. ábra: $\mathrm{A} \mathrm{CO}_{2}$ redukció egy lehetséges mechanizmusa [24]

Számos paraméter megváltoztathatja a bemutatott mechanizmust, mint például különböző elektródok, különböző $\mathrm{pH}$. Ennek tudható be, hogy $\mathrm{CO}_{2}$ redukció során számos termék keletkezhet. Amennyiben olyan elektródot választunk, amelyen a $\mathrm{CO}_{2}^{-}$és az elektród közötti kölcsönhatás nagyon erős, viszont a redukciós terméke, a CO erre nem képes, akkor nagyfokú szelektivitást tapasztalhatunk a termékképződés felé. Míg más esetekben, ha már az elektród- $\mathrm{CO}_{2}{ }^{\circ}$ kölcsönhatás sem erős, az anyagon döntően csak $\mathrm{H}_{2}$ fejlödés tapasztalható [24].

\subsection{Fotoelektródokról általában, különös tekintettel a fotokatódokra}

Amennyiben a fotoelektrokémiai reakció során redukciós folyamat megy végbe, akkor ez a fotokatódon játszódik le, amely jellemzően p-típusú félvezető. A továbbiakban ezeknek az anyagoknak néhány fontosabb paraméterét, illetve a gyakorlati alkalmazás követelményeit tekintjük át.

1. A tiltott sáv megfelelő szélessége: Nagyon fontos, hogy a p-típusú félvezető vezetési sávjának negatívabb potenciállal kell rendelkeznie, mint az adott redoxi rendszer elektrokémiai potenciálja. Az is fontos elvárás emellett a félvezetővel szemben, hogy a tiltottsáv-szélessége lehetőleg minél jobban megfeleljen a napsugárzás spektrumának. 
Ennek érdekében olyan félvezetőkre van szükség, amelyeknek a tiltottsáv-szélessége 1,0 2,2 eV közt van. 3,0 eV-nál nagyobb a tiltottsáv-szélesség esetén az anyag csak a nagy energiájú fényt (UV) képes elnyelni, ami limitálja a felhasználást. Ennek kiküszöbölésére egy lehetséges megoldás lehet például festékanyagok alkalmazása, vagy más, kisebb tiltott sávú anyagokkal való kombinálás. Szintén problémát okoz, ha a tiltottsáv-szélessége túl kicsi, mert ebben az esetben a töltéshordozók rekombinációja sokkal jelentősebb lesz, mint széles tiltott sáv esetén.

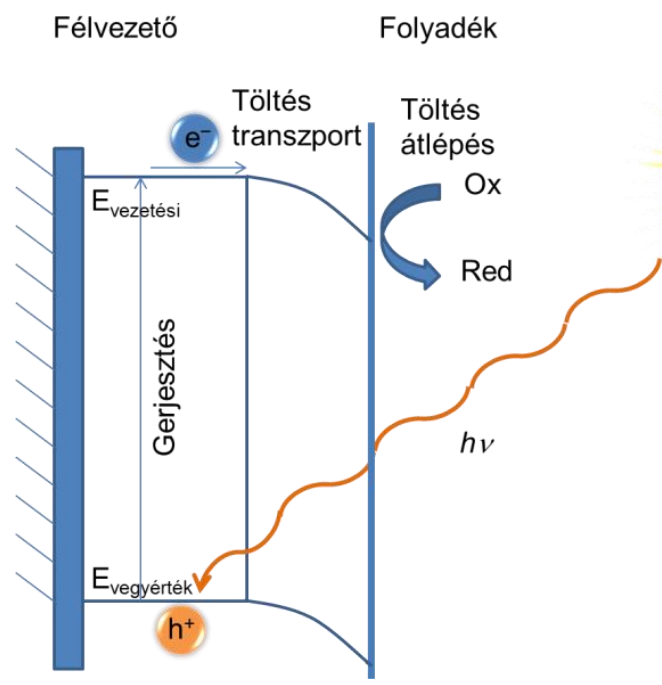

6. ábra: Megvilágítás hatására a fotokatódon lejátszódó legfontosabb folyamatok.

2. Hatékony töltéstranszport a félvezetőn belül: A megvilágítás hatására képződő töltéshordozóknak fontos, hogy rövid időn belül elérjék a félvezetö/elektrolit határfelületet, illetve ezzel egyidejűleg az elektronlyukaknak (vagy elektronoknak) a külső áramkörön keresztül a másik elektródra kell kerülniük. A félvezető határrétegének olyan szerkezettel kell rendelkeznie, melyben a töltéshordozók mozgékonysága nagy, míg a többségi töltéshordozóknak az oldatba való jutása gátolt. A p-típusú félvezetők esetén minél nagyobb az elektronok (n-típusú anyagoknál a lyukak) mobilitása, annál nagyobb a mérhető redukciós (oxidációs) fotoáram. A gyors töltéstranszport eredményeként a rekombináció esélye lecsökken, ami a hatásfok növekedéshez vezethet.

3. Gyors töltéstranszfer a félvezetőről a redukálandó anyagra: A félvezető vezetési sávjának és a redukálandó részecske redoxi potenciáljának relatív elhelyezkedése csupán a fotoelektrokémiai redukció termodinamikai lehetőségét adja meg. Számos olyan rendszer ismert, ahol nem megy végbe a reakció a kinetikai gátlás miatt. Ilyen esetekben megoldást jelenthet mediátor molekulák, vagy elektrokatalizátorok alkalmazása a határfelületen vagy az oldatban, mivel ezek csökkentik a folyamat aktiválási energiáját. 
4. Szelektivitás a kívánt termék irányába: Amennyiben a határfelületen több, egymáshoz közel eső redukciós potenciállal rendelkező anyag van jelen, akkor az egyes folyamatok között versengés alakul ki. A szén-dioxid redukciója során a proton redukció és a $\mathrm{CO}_{2}$ redukciós folyamatok között mindig versengés van.

A szelektivitást a Faraday-hatásfokkal ( $(\xi)$ szokás kifejezni, ami megmutatja, hogy az elektrokémiai folyamat során áthaladt elektronok (töltés) hányadrésze fordítódott az adott termék keletkezésére [20]:

$$
\xi=\frac{\text { Termékekre fordítódott töltés }}{\text { Összes töltés }}
$$

A szelektivitás növelhető a félvezető anyagi minőségének módosításával, bizonyos mediátor molekulák alkalmazásával, az alkalmazott potenciál változtatásával, vagy esetenként specifikus hullámhosszúságú fény alkalmazásával (pl. lézerek alkalmazása).

5. A fotokatód stabilitása: A félvezetőknél fontos szempont a hosszú távú stabilitás, mivel csak a kifejezetten stabil anyagokat lehet felhasználni később ipari alkalmazások során. A félvezetők többféle módon degradálódhatnak, és ezek között megkülönböztetünk kémiai és (foto)elektrokémiai korróziót, valamint fizikai degradációt. Kémiai korrózió során a félvezető anyaga az oldatban található valamilyen komponenssel lép kölcsönhatásba. Elektrokémiai korrózióról akkor beszélünk, ha a redukció során alkalmazott potenciáltartományban a fotoelektród anyagát is érintő elektródreakciók is lejátszódhatnak ( $\mathrm{pl}$. $\mathrm{CuO}$ és $\mathrm{Cu}_{2} \mathrm{O}$ redukálódik elemi rézzé). A fotoelektrokémiai korróziót a megvilágítás hatására keletkező fotoelektronok és lyukak által kiváltott, az elektródot érintő, nem kívánt mellékreakciók okozzák. Ez a hatás főként az n-típusú félvezetőket érinti a felületre kerülő lyukak oxidáló hatása miatt, míg p-típusú félvezetők esetén az elektronok inkább védelmet nyújthatnak oxidatív korróziós folyamatokban (azonban pl. $\mathrm{Cu}_{2} \mathrm{O}$ esetén fotokorrózió lép fel).

\subsection{Oxid alapú fotoelektródok}

\subsubsection{Egyszerü oxidok}

A kutatások során a leginkább tanulmányozott fotoelektród típus az oxidok csoportja. A különböző oxidok sávpozíciói, illetve tiltottsáv-szélessége széles tartományon változik $(1,8-3 \mathrm{eV})$. Ennek köszönhetően gyakorlatilag bármilyen fotoelektrokémiai reakció megvalósítható a megfelelő fém-oxid alkalmazásával. Néhány a kutatások során gyakran vizsgált egyfémes oxid tulajdonságait a 2. táblázat foglalja össze: 


\begin{tabular}{|c|c|c|c|}
\hline Fém-oxid & Félvezető típus & Tiltottsáv-szélesség & Referencia \\
\hline $\mathrm{TiO}_{2}$ & n-típus & $3,0-3,2 \mathrm{eV}$ & {$[25]$} \\
\hline $\mathrm{Fe}_{2} \mathrm{O}_{3}$ & n-típus & $2,1 \mathrm{eV}$ & {$[26]$} \\
\hline $\mathrm{Cu}_{2} \mathrm{O}$ & p-típus & $1,9-2,2 \mathrm{eV}$ & {$[16]$} \\
\hline $\mathrm{CuO}$ & p-típus & $1,4-1,7 \mathrm{eV}$ & {$[27]$} \\
\hline $\mathrm{NiO}$ & p-típus & $3,6 \mathrm{eV}$ & {$[28]$} \\
\hline $\mathrm{WO}_{3}$ & n-típus & $2,6 \mathrm{eV}$ & {$[29]$} \\
\hline $\mathrm{ZnO}$ & n-típus & $3,2 \mathrm{eV}$ & {$[29]$} \\
\hline
\end{tabular}

2. táblázat: A leggyakrabban alkalmazott egyfémes oxidok.

A továbbiakban a p-típusú egyfémes oxid félvezetők jellemzőit fogom áttekinteni. Az egyik legtöbbet tanulmányozott fotoelektród a $\mathrm{Cu}_{2} \mathrm{O} \cdot \mathrm{A} \mathrm{Cu}_{2} \mathrm{O}$ egy olyan félvezetö, amely a szintézis körülményektől függően lehet $n$ - vagy p-típusú félvezető, és már sikeresen alkalmazták katalízisben [30], fotoelektródként [31] és napelemekben [32] is. $\mathrm{A} \mathrm{Cu}_{2} \mathrm{O}$ egy köbös rácsban kristályosodó anyag. A tiltottsáv-szélessége 2,0-2,2 eV között változik, így a látható fény jelentős részét képes elnyelni, valamint a vezetési és vegyérték sáv elhelyezkedése olyan, hogy közrefogja a víz oxidációs, valamint a víz és a $\mathrm{CO}_{2}$ redukciós potenciál értékekeit. Ez termodinamikailag lehetőséget ad $\mathrm{H}_{2}, \mathrm{O}_{2}$ valamint $\mathrm{CO}_{2}$ redukciós termékek előállítására. Számos egyéb oka is van annak, hogy ez az anyag a kutatások központjában áll. Nagy mennyiségben, egyszerü (például elektrokémiai) módszerekkel előállítható $[33,34]$, továbbá nem mérgező. További előnyös tulajdonsága, hogy a nagy tisztaságú $\mathrm{Cu}_{2} \mathrm{O}$ kristály nagyon jó lyukvezető tulajdonsággal rendelkezik [35].

A részecskék méretének és morfológiájának szabályozása is fontos, mivel ezáltal maximálni tudjuk a felszíni reakciók sebességét, hatásfokát [35]. Például bizonyos kristályorientációk a kristályrácsban képesek az elektronok és/vagy az elektronlyukak mozgékonyságát növelni vagy csökkenteni. A kisebb részecskéknek nagyobb felületük lehet, és ez növelheti az aktív felületeket az oxidációs vagy a redukciós folyamatok során. $\mathrm{A} \mathrm{Cu}_{2} \mathrm{O}-b o ́ l$ könnyen kialakíthatóak különböző morfológiájú részecskék [36,37].

$\mathrm{A} \mathrm{Cu}_{2} \mathrm{O}$ hatékony fotokatódként alkalmazható, azonban termodinamikailag nem stabil

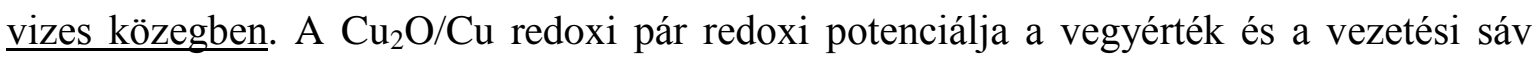
között helyezkedik el, és ezért önmagát redukálja megvilágítás hatására, a következő egyenlet alapján [38]: 


$$
\mathrm{Cu}_{2} \mathrm{O}+2 \mathrm{H}^{+}+2 \mathrm{e}^{-} \rightarrow 2 \mathrm{Cu}+\mathrm{H}_{2} \mathrm{O}
$$

Ennek megakadályozására különböző védőrétegek, például $\mathrm{MoS}_{2}$ [39], $\mathrm{TiO}_{2}$ [40], illetve $\mathrm{Ga}_{2} \mathrm{O}_{3}$ [41] hatását vizsgálták.

Egy másik intenzíven vizsgált p-típusú félvezető a NiO, amely egy környezeti behatásokkal szemben ellenálló, elektrokémiailag stabil, olcsó anyag. Ezen tulajdonságai lehetővé teszik, hogy modell rendszerként is alkalmazható is legyen. A gyakorlati alkalmazások során a festékkel érzékenyített napelemekben [42], elektrokromofórként [43], vízredukciós folyamatokban [43,44] vizsgálták. Szilárd állapotban a nátriumkloridéhoz hasonló lapcentrált köbös rácsban kristályosodik [43]. A NiO tiltottsávszélessége 3,6 eV, így fényelnyelése föként az UV-tartományba esik.

A nikkel-oxid alapú anyagok elektrokróm sajátságokat mutatnak (az optikai tulajdonságok függnek az oxidációs állapottól), mely a különböző nikkel tartalmú fázisok jelenlétéhez köthető. Így különböző hidroxidok, oxihidroxidok és ezek módosulatainak összességeként fordulhat elő, melyek különböző redoxi folyamatokat kísérő $\mathrm{H}^{+}$illetve $\mathrm{OH}^{-}$ cserefolyamatok révén alakulnak egymásba [43]. Ezek a redoxi átalakulások reverzibilisek, így ezen reakciók töltés tárolására is felhasználhatók. A különböző oxidok és hidroxidok hevítéssel is átalakíthatóak egymásba. A hőkezelés hatására elérhető, hogy az egyetlen fázis a kristályos $\mathrm{NiO}$ legyen [43].

\subsection{2. Összetett oxidok}

Az előző fejezetben láthattuk, hogy az egyszerü oxidoknak számos hátrányuk van (pl. széles tiltott sáv, fotokorrózió), amely miatt önmagukban nem teljesítik az összes feltételt, ami egy ideális fotoelektródra jellemző.

Egy lehetséges megoldás, hogy különböző egyszerü oxidokból kiindulva, kétfémes oxidokat alakítunk ki. Ilyenek például az $\mathrm{AMO}_{2}$ összetételü delafosszitok, amelyek egy +1 -es és egy +3 -as oxidációs állapotú fémiont tartalmaznak. Az „A” egy +1 oxidációs állapotú átmeneti fémet (mint például $\mathrm{Ag}^{+}$vagy $\mathrm{Cu}^{+}$) jelöl, amíg az „,M” egy +3 oxidációs állapotú fémion $\left(\mathrm{Fe}^{3+}, \mathrm{Cr}^{3+}, \mathrm{Ga}^{3+}, \mathrm{Rh}^{3+}\right.$ vagy $\left.\mathrm{Al}^{3+}\right)$.

A továbbiakban a réz alapú delafosszitokat fogom részletezni, mivel munkám során ezzel a delafosszit csoporttal foglalkoztam. A réztartalmú delafosszitokat számos módon állították már elő: ezek közül a legfontosabbak a szilárdfázisú szintézis [45], impulzus lézer leválasztás [46], szol-gél módszer [47,48] és a hidrotermális szintézis [49]. Mivel 
azonban ezek nagy energia-befektetéssel járó eljárások, olyan elöállítási eljárásokra is szükség van, amelyek akár szobahőmérsékleten is végbemennek, mint például az elektrokémiai leválasztás [50].

A réztartalmú delafosszitok szerkezetében $\mathrm{M}^{3+} \mathrm{O}_{6}$ oktaéderek csatlakoznak lineárisan $\mathrm{Cu}^{+}$kationokhoz. Attól függően, hogy az egyes részek hogyan koordinálódtak, két kristályforma alakulhat ki: hexagonális $(2 \mathrm{H})$ vagy romboéderes $(\mathrm{R} 3 \mathrm{~m})$ (7. ábra). Fontos azonban megjegyezni, hogy ezen kristályszerkezetek tisztán nem állíthatóak elö, mindig van jelen a másik kristályfázisból. Az összetételt nagyban befolyásolja, hogy a nagy hőmérsékletü szintézist követően milyen sebességgel hül le a delafosszit. Amennyiben a lehülés gyors, akkor az a $2 \mathrm{H}$ formának kedvez, míg a lassú lehülés a R3m szerkezetnek [51].

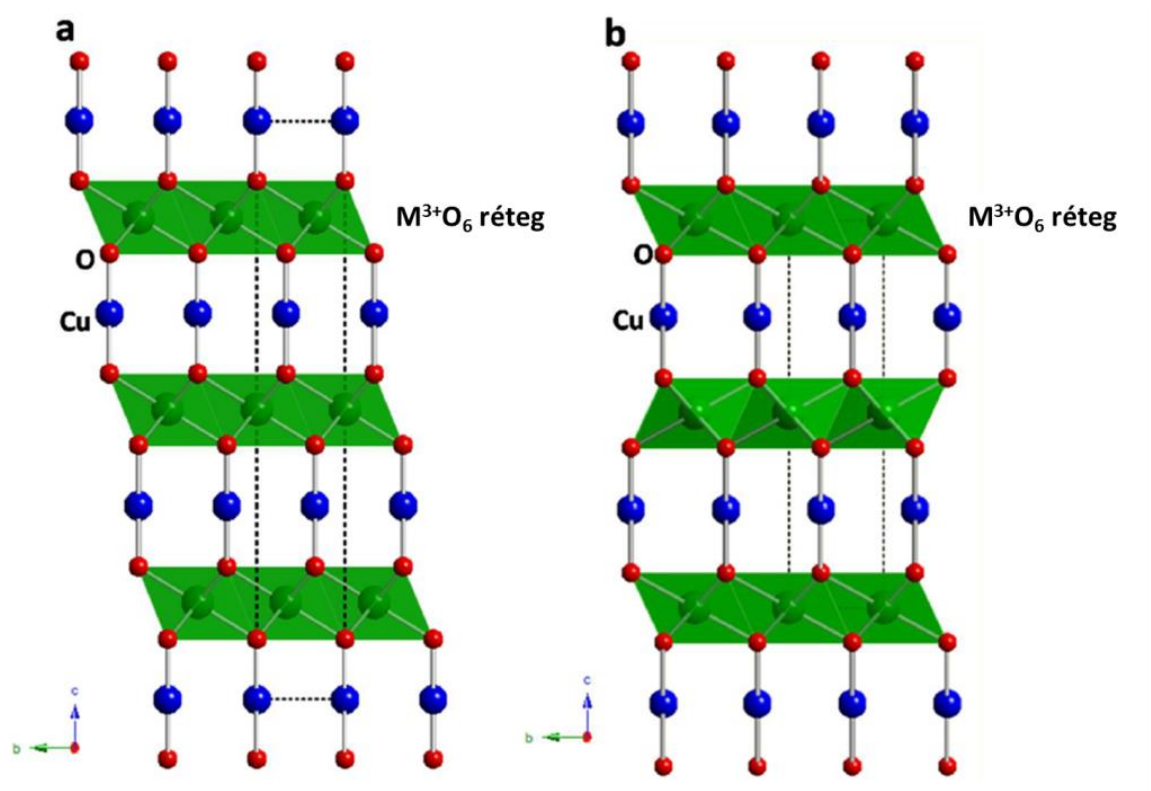

7. ábra: A delafosszitok két jellemző polimorf módosulata: (A): hexagonális $2 \mathrm{H},(\mathrm{B})$ : romboéderes R3m [16].

A delafosszitok sávszerkezetéröl elmondható, hogy más $\mathrm{Cu}^{+}$alapú keverék oxidokhoz hasonlóan a vegyérték sávjukat a $\mathrm{Cu} \mathrm{d}{ }^{10}$, vezetési sávjukat pedig föleg a $\mathrm{M}^{3+}$ fémion $\mathrm{d}$ és $\mathrm{s}$ pályái alkotják. Mivel számos kombináció lehetséges, ezért tiltottsáv-szélességük széles tartományban változik $(1,2-3,5 \mathrm{eV})$, amit a 8. ábra szemléltet [16]. Mivel ezzel képesek lefedni a látható fény hullámhossz tartományát, ezért alkalmazhatóak a napenergia hasznosításban.

A delafosszitok széles pH tartományban stabilak [48], illetve ezen anyagokra nem jellemző a $\mathrm{Cu}_{2} \mathrm{O}$-nál tapasztalt fotodegradáció. A delafosszitoknak a kedvező tiltottsáv- 
szélességük mellett a sávpozíciójuk is lehetőséget biztosít arra, hogy víz, valamint $\mathrm{CO}_{2}$ redukciós folyamatokban vegyenek részt.

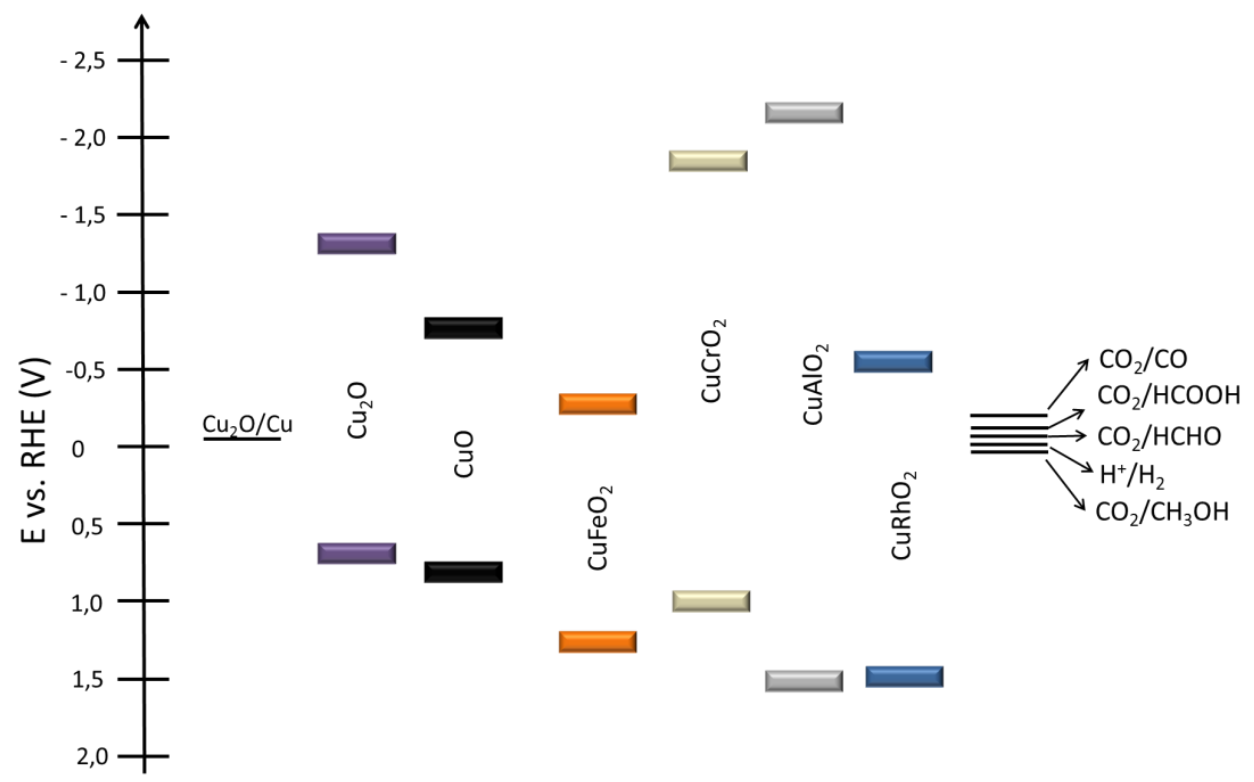

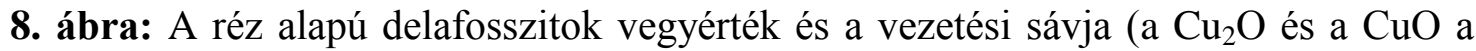
jobb összehasonlítás érdekében van feltüntetve); a fontosabb $\mathrm{CO}_{2}$ és víz redukciós potenciál értékek, valamint a $\mathrm{Cu}_{2} \mathrm{O}$ fotokorróziós potenciálja $[38,50,52-56]$.

Az egyik legintenzívebben tanulmányozott képviselöjük a $\mathrm{CuFeO}_{2}$ [57-60], melynek a látható tartományba esik a fényelnyelése, és alkalmazták már $\mathrm{CO}_{2}$ fotoelektrokémiai redukcióra [50,61]. Az elektrokémiai tulajdonságait Mg adalékolásával javították, melynek eredményeként megnövekedett fotoelektrokémiai aktivitást mutatott [62,63].

$\mathrm{A} \mathrm{CuRhO}_{2}$ [54] és $\beta-\mathrm{CuGaO}_{2}$ [64] delafosszitoknak is a látható tartományba esik a fényelnyelése. $\mathrm{A} \mathrm{CuRhO}_{2}$-t sikeresen alkalmazták víz-redukciós folyamatokban, valamint azt tapasztalták, hogy egy hosszú idejü (8 órás) elektrolízist követően a fotoelektrokémiai aktivitás egy alacsony hőmérsékletű $\left(100^{\circ} \mathrm{C}-\mathrm{os}\right)$ hőkezeléssel majdnem teljesen visszanyerhető [54].

Nagy sávszélességgel rendelkező delafosszitokban az $\mathrm{M}^{3+}$ ion lehet például Sc, Ga, Al, Cr, B. Ezeket az anyagokat föleg lyukvezetőként alkalmazták [65]. Ezen delafosszitok közül pl. a $\mathrm{CuCrO}_{2}$ fotoelektrokémiai aktivitását vizsgálták víz-redukciós folyamatokban [66]. A stabilitását széles pH tartományon tesztelték [48], továbbá vizsgálták különböző fémionok (például $\mathrm{Ni}^{2+}, \mathrm{Cd}^{2+}, \mathrm{Hg}^{2+}$ ) eltávolításra való alkalmazhatóságát fotokatalitikus reakciókban [67], valamint a $\mathrm{HCl}$ átalakítását is [68]. Azokban az esetekben azonban, amelyek során víz redukciós folyamatokban alkalmazták, nem erősítették meg a $\mathrm{H}_{2}$ fejlődést közvetlen mérési technikával. 


\subsubsection{Kompozit elektródok}

Mint azt bemutattam, az egyfémes esetekben az alkalmazott elektródok nem képesek egymagukban teljesíteni az ideális elektróddal szemben támasztott elvárásokat. Azoknál az elektródoknál viszont, amelyek tiltottsáv-szélessége megfelelő volna a látható fény nagymértékü hasznosításhoz (pl. $\left.\mathrm{Cu}_{2} \mathrm{O}\right)$, gyakran fotokorrózióval kell számolni.

Lehetőség van azonban arra, hogy az különböző anyagokat kombinálva kompozit elektródokat hozzunk létre. A kompozitokban az egyes anyagok pozitív tulajdonságai egymást erősíthetik és/vagy a hátrányos tulajdonságok háttérbe szorulását tapasztalhatjuk. Ilyen előny lehet például az, hogy a látható fény nagyobb részét képesek elnyelni.

Számos anyagot használtak már fel kompozit elektródok kialakításához. Az egyik legegyszerübb megoldás, amikor két különböző félvezetőt (lehet két azonos vagy két különböző típusú félvezető) kombinálnak. Ennek számos előnye lehet, mint pl. (i) megnövekedett fényelnyelés, (ii) jobb töltésszeparáció, (iii) a töltés rekombináció visszaszorítása, (iv) valamint a kisebb tiltottsáv-szélességü anyagok fotokorróziójának megelőzése [43].

Az elkövetkezőkben néhány példát mutatok be arra, hogy milyen előnyökkel járhat a kedvező sávpozíciók kialakítása különböző félvezetőkből.

Szén-dioxid redukcióra alkalmaztak már $\mathrm{Cu}_{2} \mathrm{O} / \mathrm{CuO}$ fotoelektródot (9. ábra) [69]. Ehhez először rézlemez felszínére egy $\mathrm{CuO}$ nanostruktúrát készítettek, majd ennek felületére választották le elektrokémiai eljárással $\mathrm{Cu}_{2} \mathrm{O}$-ot. A fotoelektrokémiai szén-dioxid redukció során a termék metanol volt, és az anyagon megnövekedett fotoaktivitást mértek az egyszerű $\mathrm{Cu}_{2} \mathrm{O}$-hoz képest. $\mathrm{A} \mathrm{Cu}_{2} \mathrm{O}$ vezetési sávja a $\mathrm{CuO}$ vezetési sávjánál negatívabb potenciálon helyezkedik el, emiatt a $\mathrm{Cu}_{2} \mathrm{O}$-tól az elektronok a $\mathrm{CuO}$ vezetési sávjába juthatnak. A megnövekedett aktivitás mögött az is állhat, hogy a $\mathrm{Cu}_{2} \mathrm{O}$ közvetlenül a folyadékfázissal is érintkezésben volt, nem csak a CuO-dal, és a megvilágítás hatására a keletkező töltéshordozók közvetlenül a $\mathrm{CO}_{2}$-dal is tudtak reagálni. Valószínüleg ez a két folyamat együttesen járult hozzá a megnövekedett fotoelektrokémiai aktivitáshoz [69]. 


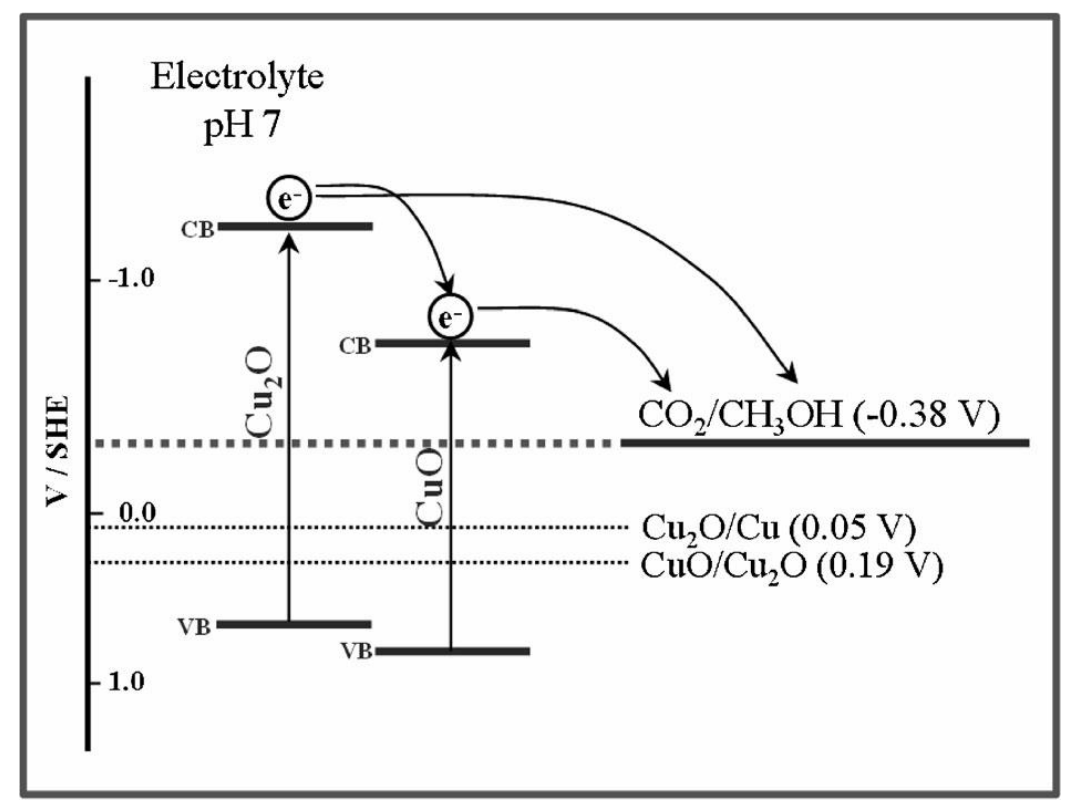

9. ábra: $\mathrm{CuO} / \mathrm{Cu}_{2} \mathrm{O}$ kompozit sávpozíciója és $\mathrm{CO}_{2}$ redukciós folyamata [69]

Egy másik esetben $\mathrm{CuFeO}_{2}-\mathrm{t}(1,45 \mathrm{eV})$ és $\mathrm{CuAlO}_{2}$-t $(3,51 \mathrm{eV})$ kombináltak (10. ábra). $\mathrm{A} \mathrm{CuFeO}{ }_{2}$ mellé azért választották a $\mathrm{CuAlO}_{2}$-t, mert olyan anyagot kerestek, amelynek (i) nagy a tiltottsáv-szélessége; (ii) jó a lyukvezető képessége; (iii) a vezetési és vegyértéksávja pozitívabban helyezkedik el, mint a $\mathrm{CuFeO}_{2}$-nak (ezáltal megelőzhető, hogy a keletkező fotoelektronok visszafelé haladjanak); (iv) valamint a hossztávú stabilitása hasonló, mint a $\mathrm{CuFeO}_{2}$-nak.

A $\mathrm{CuAlO}_{2}$-t először szol-gél technika segítségével állították elő, majd a kész delafosszitot felvitték egy FTO elektród felszínére. A Cu:Fe 1:3 arányú elegyét spincoating technikával vitték fel a felszínre, és egy $650^{\circ} \mathrm{C}$-os hökezelést követően kapták meg a kívánt elektródot. Azt tapasztalták, hogy a fotoelektrokémiai aktivitás körülbelül két és félszer nagyobb volt a hasonló módon előállított $\mathrm{CuFeO}_{2}$-hoz képest oxigénnel telített $1 \mathrm{M}$ $\mathrm{NaOH}$ oldatban [70].

Egy másik tanulmányban $\mathrm{CuFeO}_{2} / \mathrm{CuO}$ kompozitját vizsgálták. $\mathrm{A} \quad \mathrm{CuFeO}_{2}$-ot elektrokémiailag választották le FTO-üveg felületére. Ehhez először a $\mathrm{Cu}$ :Fe prekurzorok 3:1 arányú elegyéből választották le vizes valamint nem vizes (dimetil-szulfoxid) közegből. Ezt követően az elektródokat levegőben hevítették $650{ }^{\circ} \mathrm{C}$ on, amelynek hatására kialakult a $\mathrm{CuFeO}_{2} / \mathrm{CuO}$ rendszer. 

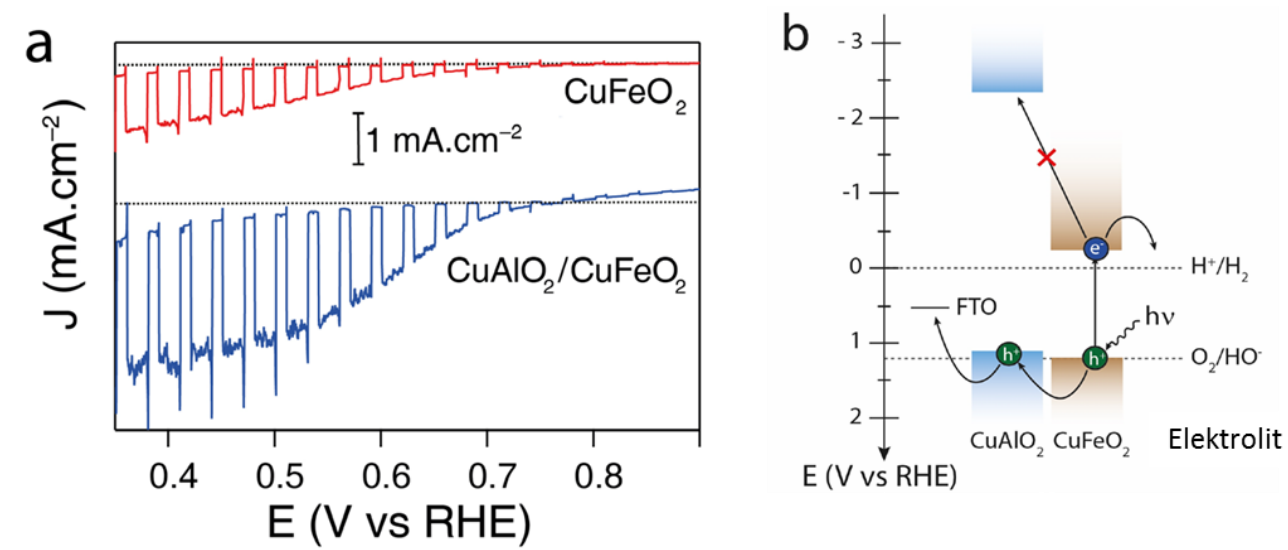

10. ábra: $\mathrm{A} \mathrm{CuFeO}_{2}$ és $\mathrm{CuAlO}_{2} / \mathrm{CuFeO}_{2}$ fotoelektrokémia aktivitása $1 \mathrm{M} \mathrm{NaOH}$-ban (a), és a két anyag sávpozíciója (b) [70]

Azt tapasztalták, hogy a vizes közegből leválasztott réteg jobban teljesített, mint a szerves fázisból leválasztott réteg (a két rétegnek különbözött a morfológiája). A sima $\mathrm{CuFeO}_{2}-\mathrm{hoz}$ képest majdnem kétszer akkora fotoáramok voltak mérhetőek (11. ábra). Az így készült rétegek közel 24 órán keresztül stabilak voltak a fotoelektrolízis során. $\mathrm{A} \mathrm{CO}_{2}$ redukció fő terméke hangyasav volt. Ebben az esetben is megnövekedett fotoaktivitást lehetett elérni kompozit elektródok alkalmazásával [71].
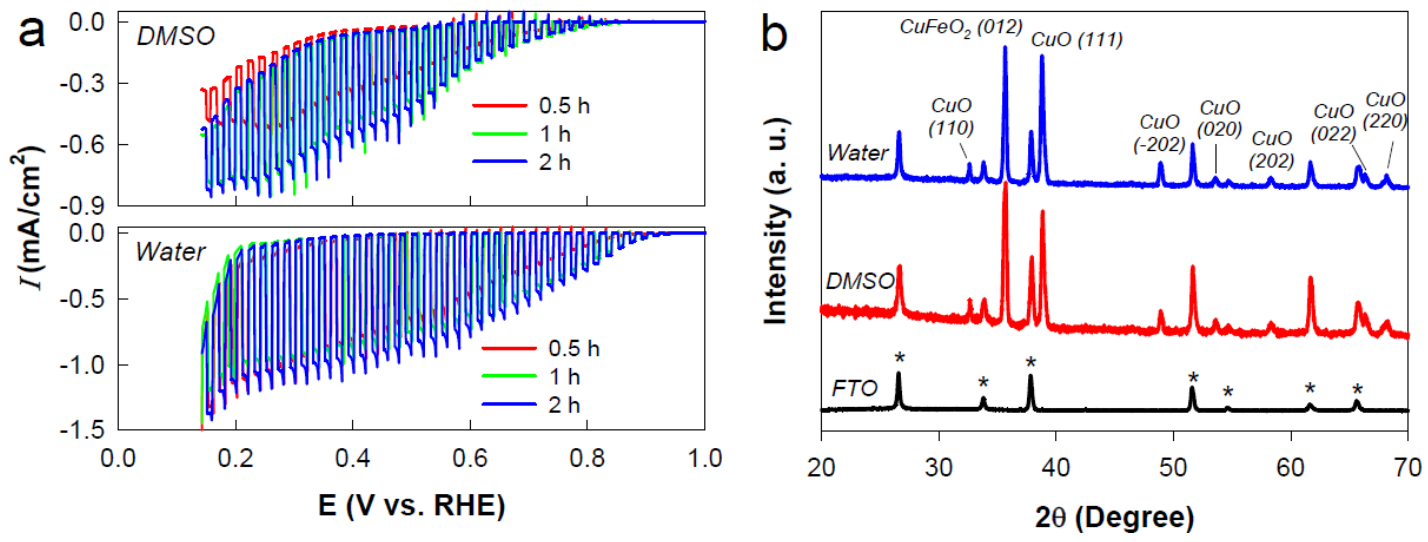

11. ábra: (a) $\mathrm{A} \mathrm{CuFeO}_{2} / \mathrm{CuO}$ rendszer fotoelektrokémiai aktivitása különböző közegekből előállítva (b); a kétfázisú rendszer röntgendiffraktogramja [71].

Az elmondottak összegzéseként a 3. táblázatban foglaltam össze néhány rézalapú kétfémes oxidot és kompozitot, amelyeket már alkalmaztak fotokatódként. Annak érdekében, hogy az egyes fotoelektrokémiai aktivitások összehasonlíthatók legyenek, a potenciálértékeket a reverzíbilis hidrogén elektróddal (RHE) szemben mutatom be. 
3. táblázat: Néhány kiválasztott példa a fotokatódként alkalmazott réz alapú kétfémes oxidokra és kompozitjaikra.

\begin{tabular}{|c|c|c|c|c|c|}
\hline Oxid & $\begin{array}{l}\text { Előállítási } \\
\text { módszer }\end{array}$ & Morfológia & $\begin{array}{l}\text { Elektrokémiai } \\
\text { viselkedés }\end{array}$ & Megjegyzés & Ref. \\
\hline \multirow[b]{2}{*}{$\mathrm{CuFeO}_{2}$} & \multirow[b]{2}{*}{$\begin{array}{l}\text { elektrokémiai } \\
\text { leválasztás }\end{array}$} & $\begin{array}{l}\text { hidratált amorf } \\
\text { fázis }\end{array}$ & $\begin{array}{c}\text { Vízredukció, } \\
0,16 \mathrm{~mA} \mathrm{~cm}^{-2} \\
0,6 \mathrm{~V} \text {-on vs. } \\
\text { RHE }\end{array}$ & $\begin{array}{c}\text { Első példa a } \mathrm{CuFeO}_{2} \\
\text { elektrokémiai } \\
\text { szintézisére. }\end{array}$ & [72] \\
\hline & & vékony-réteg & $\begin{array}{c}\mathrm{CO}_{2} \text { redukció, } \\
0,5 \mathrm{~mA} \mathrm{~cm}{ }^{-2} 0,4 \\
\text { V-on vs. RHE } \\
\text { IPCE } 8 \% 400 \\
\text { nm-nél }\end{array}$ & $\begin{array}{l}\text { A komponensek ebben a } \\
\text { p-típusú anyagban olcsó } \\
\text { átmenetifémek. } \\
\text { Reprodukálható és } \\
\text { skálázható egyszerü } \\
\text { laboratóriumi szintézis. }\end{array}$ & {$[50]$} \\
\hline $\begin{array}{l}\text { Mg-adalékolt } \\
\mathrm{CuFeO}_{2}\end{array}$ & szilárdfázisú & $\begin{array}{l}\text { szivacsos } \\
\text { klaszter }\end{array}$ & $\begin{array}{l}\mathrm{CO}_{2} \text { redukció, } \\
0,5 \mathrm{~mA} \mathrm{~cm}^{-2} \\
0,35 \mathrm{~V} \text {-on vs. } \\
\text { RHE } \\
\text { IPCE } 14 \% 340 \\
\text { nm-nél }\end{array}$ & $\begin{array}{l}\mathrm{Mg} \text {-adalékolt } \mathrm{CuFeO}_{2} \\
\text { elektródon } \mathrm{CO}_{2} \text { - redukció } \\
\text { során hangyasav } \\
\text { keletkezett megvilágítás } \\
\text { hatására. }\end{array}$ & [62] \\
\hline \multirow{3}{*}{$\begin{array}{c}\mathrm{CuFeO}_{2} / \\
\mathrm{CuO}\end{array}$} & \multirow{3}{*}{$\begin{array}{l}\text { elektrokémiai } \\
\text { leválasztás }\end{array}$} & $\begin{array}{l}\text { dupla rétegü } \\
\text { film }\end{array}$ & $\begin{array}{c}\mathrm{CO}_{2} \text { redukció, } \\
0,9 \mathrm{~mA} \mathrm{~cm}{ }^{-2} 0,4 \\
\mathrm{~V} \text {-on vs. } \mathrm{RHE} \\
\text { IPCE } 28 \% 400 \\
\text { nm-en }\end{array}$ & $\begin{array}{l}\text { Megnövekedett fotoáram } \\
\text { a } \mathrm{CuFeO}_{2} \text {-hoz képest. }\end{array}$ & {$[50]$} \\
\hline & & dupla rétegü & $\begin{array}{c}\mathrm{CO}_{2} \text { redukció, } \\
0,9 \mathrm{~mA} \mathrm{~cm}^{-2} 0,4 \\
\mathrm{~V} \text { vs. } \mathrm{RHE} ; \mathrm{STF} \\
1 \%\end{array}$ & $\begin{array}{l}\mathrm{CuFeO}_{2} / \mathrm{CuO} \text { kétfázisú } \\
\text { film, szelektíven } \\
\text { hangyasavat termelt az } \\
\text { oldott } \mathrm{CO}_{2} \text {-ból. } 17 \text { napon } \\
\text { keresztül folyamatosan } \\
\text { termelte a hangyasavat. }\end{array}$ & [71] \\
\hline & & $\begin{array}{l}\text { pórusos- } \\
\text { aggregátum }\end{array}$ & $\begin{array}{c}\mathrm{CO}_{2} \text { redukció, } \\
0,1 \mathrm{~mA} \mathrm{~cm}^{-2} \\
0,22 \mathrm{~V} \text {-on vs. } \\
\mathrm{RHE}\end{array}$ & $\begin{array}{c}\mathrm{CO}_{2} \text { acetáttá redukálódott } \\
\text { nagy Faraday hatásfok } \\
\text { mellett. }\end{array}$ & [61] \\
\hline $\begin{array}{l}\mathrm{CuFeO}_{2} / \\
\mathrm{CuAlO}_{2}\end{array}$ & spin-coating & szemcsék & $\begin{array}{l}\text { Vízredukció, } 2,4 \\
\text { mA cm }{ }^{-2} 0,35 \\
\text { V-on vs. RHE } \\
\text { IPCE } 23 \% 350 \\
\text { nm-en }\end{array}$ & $\begin{array}{l}\text { Gazda-vendég kompozit } \\
\text { elektród. }\end{array}$ & [70] \\
\hline $\mathrm{CuCrO}_{2}$ & szol-gél & szemcsék & $\begin{array}{l}\text { Vízredukció } \mathrm{H}_{2} \\
\text { detektálás } \\
\text { nélkül, } 0,5 \mathrm{~mA} \\
\mathrm{~cm}^{-2} 0,4 \mathrm{~V} \text {-on } \\
\text { vs. RHE } \\
\text { IPCE } 6 \% 350 \\
\text { nm-on } \mathrm{N}_{2} \text {-ben }\end{array}$ & $\begin{array}{l}\text { Figyelemre méltó } \\
\text { fotoelektrokémiai és } \\
\text { kémiai stabilitás. Az } \\
\text { elektród az egész pH } \\
\text { tartományon használható. }\end{array}$ & [48] \\
\hline
\end{tabular}




\begin{tabular}{|c|c|c|c|c|c|}
\hline $\mathrm{CuCrO}_{2}$ & szilárdfázisú & szemcsék & $\begin{array}{l}\text { Vízredukció } \\
0,02 \mathrm{~mA} \mathrm{~cm}^{-2} \\
0,4 \text { V-on vs. } \\
\text { RHE }\end{array}$ & $\begin{array}{c}\mathrm{A} \mathrm{CuCrO} \text { fotoáram kicsi } \\
\text { volt a sötét áramhoz } \\
\text { képest. }\end{array}$ & [66] \\
\hline $\mathrm{CuAlO}_{2}$ & $\begin{array}{l}\text { elektro-kémiai } \\
\text { leválasztás }\end{array}$ & $\begin{array}{c}\text { virág-szerü } \\
\text { három- } \\
\text { dimenziós } \\
\text { aggregátumok }\end{array}$ & $\begin{array}{l}\text { Vízredukció, } \\
1 \text { mA cm }{ }^{-2} \\
\text { 0,4 V-on vs. } \\
\text { RHE } \\
\text { IPCE: } 15 \% 400 \\
\text { nm-on }\end{array}$ & $\begin{array}{c}\text { A galvanizáló oldat } \\
\text { jelentősen befolyásolta a } \\
\text { felületi tulajdonságokat, } \\
\text { kristály szerkezetet, a } \\
\text { fotoelektrokémiai } \\
\text { tulajdonságait a } \mathrm{CuAlO}_{2-} \\
\text { nak }\end{array}$ & [73] \\
\hline $\mathrm{CuRhO}_{2}$ & szilárdfázisú & $\begin{array}{l}\text { pórusos, jól } \\
\text { definiált } \\
\text { kristályok }\end{array}$ & $\begin{array}{l}\text { Víz redukció, } \\
1 \mathrm{~mA} \mathrm{~cm}^{-2} \\
0,17 \mathrm{~V} \text {-on vs. } \\
\text { RHE } \\
\text { IPCE eléri a } \\
\text { 20\%-ot } 350 \mathrm{~nm} \text { - } \\
\text { en }\end{array}$ & $\begin{array}{l}\text { Oxigénnel segített } \\
\text { öngyógyulási folyamat az } \\
\text { elektród/elektrolit } \\
\text { határfelületen. }\end{array}$ & [54] \\
\hline $\mathrm{CuVO}_{3}$ & szilárdfázisú & $\begin{array}{l}\text { mikro-méteres } \\
\text { részecskék } \\
\text { sima } \\
\text { felszínnel }\end{array}$ & $\begin{array}{l}\text { Víz redukció, } \\
0,25 \mathrm{~mA} \mathrm{~cm}^{-2} \\
0,38 \mathrm{~V} \text { vs. } \mathrm{RHE}\end{array}$ & $\begin{array}{l}\text { Kis tiltottsáv-szélességű } \\
\text { félvezető szerény } \\
\text { fotoelektrokémiai } \\
\text { aktivitással. }\end{array}$ & [74] \\
\hline $\mathrm{CuNb}_{2} \mathrm{O}_{6}$ & $\begin{array}{c}\text { oldat- } \\
\text { belobbantásos }\end{array}$ & $\begin{array}{l}\text { pórusos, } \\
\text { aggregátumok }\end{array}$ & $\begin{array}{c}\mathrm{CO}_{2} \text { redukció, } \\
0,15 \mathrm{~mA} \mathrm{~cm}{ }^{-2} \\
0,22 \mathrm{~V} \text {-on vs. } \\
\text { RHE } \\
\text { IPCE } 5.2 \% 460 \\
\text { nm-en }\end{array}$ & $\begin{array}{l}\text { A nanorészecskék } \\
\text { fajlagos felülete nagyobb, } \\
\text { mint a kereskedelmi } \\
\text { forgalomban kapható } \\
\text { mintáknak. Ez tény } \\
\text { kiemeli az } \\
\text { oldatbelobbantásos eljárás } \\
\text { (SCS) fontosságát } \\
\text { nanorészecskék } \\
\text { elöállítására katalitikus } \\
\text { reakciókhoz. }\end{array}$ & [75] \\
\hline$\alpha-\mathrm{Cu}_{2} \mathrm{Ta}_{4} \mathrm{O}_{11}$ & \multirow{2}{*}{ szilárdfázisú } & \multirow{2}{*}{$\mathrm{n} / \mathrm{a}$} & $\begin{array}{l}\text { Víz redukció, } \\
0,2 \mathrm{~mA} \mathrm{~cm}^{-2} \\
0,23 \text { V-on vs. } \\
\text { RHE }\end{array}$ & \multirow{2}{*}{$\begin{array}{c}\text { Különböző fázisa } \\
\text { ugyanannak az anyagnak } \\
\text { jelentös különbségeket } \\
\text { okozhat a } \\
\text { fotoelektrokémiai } \\
\text { aktivitásban. }\end{array}$} & \multirow{2}{*}{ [76] } \\
\hline$\beta-\mathrm{Cu}_{2} \mathrm{Ta}_{4} \mathrm{O}_{11}$ & & & $\begin{array}{l}\text { Víz redukció, } \\
0,7 \mathrm{~mA} \mathrm{~cm}^{-2} \\
0,23 \mathrm{~V} \text {-on vs. } \\
\text { RHE }\end{array}$ & & \\
\hline
\end{tabular}

Egy másik lehetőség kompozit elektródok kialakítására, hogy a félvezető felszínére egy katalizátort választanak le annak érdekében, hogy csökkentsék a túlfeszültséget, illetve a redoxi reakció aktiválási energiáját. Sok esetben a segédkatalizátor segítheti a fotogenerált kisebbségi töltéshordozók hatékonyabb kinyerését a félvezetőből, és aktív felületet biztosítanak a redoxi reakció lejátszódásához [77,78]. A katalizátorok elektrokatalitikus aktivitása egy ún. vulkán görbe szerint változik (12. ábra). Azok az 
anyagok, amelyek közelebb vannak a görbe maximumához, nagyobb aktivitást mutatnak az adott reakcióban. Egy jó elektrokatalizátor képes csökkenteni a folyamat lejátszódásához szükséges túlfeszültséget, illetve növelheti a reakciósebességet.

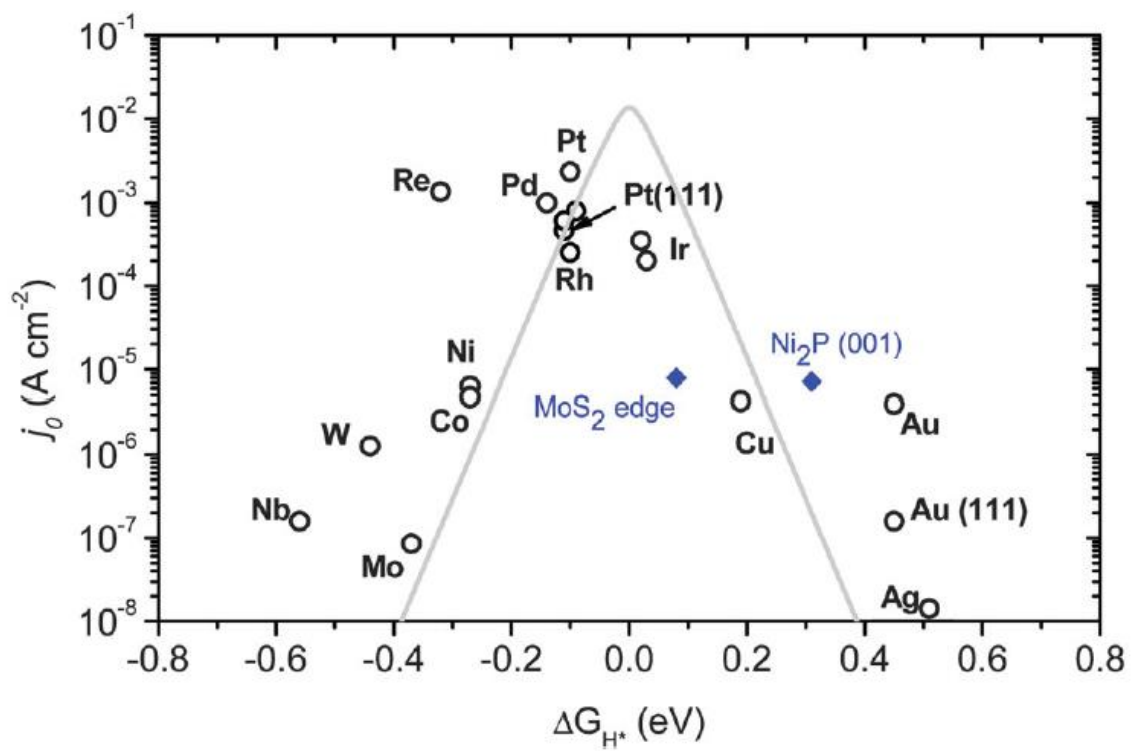

12. ábra: $\mathrm{A} \mathrm{H}_{2}$ fejlesztésre használt elektrokatalizátorok vulkán görbéje [77]

Fontos, hogy segédkatalizátorok használata előtt a stabilitásukat is figyelembe kell venni, mivel előfordulhat, hogy nagy alkalmazott potenciál hatására megváltoznak. Fontos továbbá, hogy más anyagok ne legyenek az elektródok felszínén, mivel ezek mérgezhetik a katalizátort. Figyelmet kell fordítani arra is, hogy megfelelő mennyiségü és vastagságú katalizátort vigyünk fel az elektród felszínére. Ez azért fontos, mert amennyiben túl sok elektrokatalizátor kerül az elektród felszínére, az a fényelnyelést is blokkolhatja.

A vízredukcióhoz általában nemesfém katalizátorokat alkalmaznak, mint például $\mathrm{Pt}$, $\mathrm{Rh}, \mathrm{Ru}$ és Pd. A szoros kapcsolat a nemesfém és a félvezető között Schottky-típusú átmenetet eredményez [78]. Az elektromos mező a Schottky átmenetnél úgy viselkedik, mint egy elektron csapda, ami tárolja a félvezetőről a felszínre érkező fotogenerált elektronokat. A csapdázási képesség nagyban függ a nemesfém kilépési munkájától. A platinának van a legnagyobb kilépési munkája $(6,35 \mathrm{eV})$, és ezért a legjobb választás $\mathrm{H}_{2}$ fejlődést elősegítő katalizátorként [79,80]. 


\subsection{Nem oxid alapú fotoelektródok}

A fotoelektrokémiai redukcióra számos nem oxid alapú anyag is alkalmazható. Ezeknek előnye, hogy a tiltottsáv-szélességük általában kisebb, mint az oxidoknak. Például a $\mathrm{Ta}_{2} \mathrm{O}_{5}$ tiltottsáv-szélessége 3,9 eV, míg ez a $\mathrm{Ta}_{3} \mathrm{~N}_{5}$ esetében $2,1 \mathrm{eV}$. A vegyérték és vezetési sáv pozíciójának elhelyezkedése alkalmassá teszi ezeket az anyagokat arra, hogy víz redukciós, illetve víz oxidációs folyamatokban is alkalmazhatóak legyenek [81].

A nem oxid alapú fotoelektródok egyik legnagyobb csoportja, a fém-kalkogenidek családja. Ezen anyagokban az oxidok helyett szulfidok, telluridok, szelenidek találhatók [82]. Ezeket az anyagokat már sikeresen alkalmazták elektrokémiai [83] és fotoelektrokémiai vízredukcióra [84,85], azonban legtöbbször fémoxidok érzékenyítésére szokták alkalmazni őket [86]. Legnagyobb hátrányuk, hogy vizes közegben történő megvilágítás során gyakran végbemegy fotokorróriójuk. Ennek megakadályozására általában az elektrolithoz valamilyen elektronlyuk elnyelöt adnak (mint pl. $\mathrm{Na}_{2} \mathrm{~S}$ ). Egyes kalkogenidek esetén azonban (mint például a $\mathrm{GaS}$ ) nem kell számolni a fotokorrózióval. Különböző paraméterek megváltoztatásával ezeknek az anyagoknak a tulajdonságait is jelentősen lehet befolyásolni, például CdSe esetén az elektrontranszfer sebességet három nagyságrenddel növelték meg azáltal, hogy csökkentették a nanorészecskék átmérőjét [87].

Manapság a kutatások arra is irányulnak, hogy oxid és nem oxid anyagokból egy új anyagot hozzanak létre. Ilyen anyagok lehetnek az oxinitridek és az oxiszulfidok $[88,89]$. Az oxinitridek esetében a tiltottsáv-szélessége 1,7 - 2,5 eV között változik. Lyukcsapda jelenlétében már használták őket hidrogénfejlesztésre. Ezen anyagoknál az tapasztalható, hogy amikor az oxigének nitrogénre cserélődnek a szerkezetben, akkor a vegyértéksáv helyzete megváltozik, egyre pozitívabb lesz, míg a vezetési sáv helyzete nem változik. Ennek köszönhetően a látható fénynek egyre nagyobb részét képesek elnyelni, miközben redukciós képességük nem változik. Ezen anyagokat már sikeresen felhasználták a víz oxidációs és redukciós folyamataiban, bár a redukciós folyamatok körülbelül egy nagyságrenddel lassabban megy végbe rajtuk, mint a víz oxidációja [90]. A legtöbb esetben az ilyen anyagoknál kis mennyiségü $\mathrm{N}_{2}$ fejlődés is tapasztalható, ami a oxinitridek bomlásához köthető [91]. 


\section{Célkitüzés}

Doktori munkám során olyan p-típusú, oxid-alapú összetett elektródok elöállítását tüztem ki célul, melyek alkalmasak lehetnek víz és $\mathrm{CO}_{2}$ fotoelektrokémiai redukciójára.

Vizsgálni kívántam, hogy miként befolyásolja a félvezető és a ko-katalizátor morfológiája a fotoelektrokémiai folyamat hatékonyságát nanoszerkezetü félvezető/fém fotoelektródok esetében. Ehhez p-típusú $\mathrm{NiO}$ elektródokat kívántunk előállítani anodizáció segítségével. Az így készített pórusos elektródok fotoelektrokémiai aktivitását kívántuk feljavítani különböző méretű és mennyiségü Pt nanorészecskék felületi rögzítésével.

További célunk volt, hogy egy olyan p-típusú összetett oxidot hozzunk létre, amelynek nanostrukturált morfológiája hatékony töltés transzportot eredményez. Ehhez egy olyan összetett oxidot $\left(\mathrm{CuCrO}_{2}\right)$ kívántunk előállítani, amelyet nem alkalmaztak még fotoelektrokémiai szén-dioxid redukciós folyamatokban. Emellett bizonyítani akartuk, hogy az oldatbelobbantásos eljárással (solution combustion synthesis) a szintézismódszerrel közel fázis tiszta anyag állítható elő.

Célunk volt továbbá, hogy az előzőekben előállított $\mathrm{CuCrO}_{2}$-ot egy olyan, látható tartományban fényelnyelő anyaggal kombináljuk $\left(\mathrm{CuFeO}_{2}\right)$ amely alkalmasnak bizonyultak már fotoelektrokémiai $\mathrm{CO}_{2}$ redukciós folyamatban. Vizsgálni kivántuk azt is, van-e annak hatása, hogy ha a két félvezető oxidból egyfázisú-, illetve kétfázisú anyagot hozunk létre. Ezen anyagok tulajdonságait össze kívántuk hasonlítani a kiindulási anyagokéval. 


\section{Kísérleti módszerek és alkalmazott technikák}

\subsection{Felhasznált vegyszerek}

4.1.1. Pt/NiO szintéziséhez és jellemzéséhez

Ni fólia

(99,9+\%, 0,125 mm vastag, Sigma-Aldrich);

$\mathrm{NH}_{4} \mathrm{~F}$ ( $\geq 99 \%$, Sigma-Aldrich);

Etilén-glikol ( $\geq 99 \%$ Sigma-Aldrich);

$\mathrm{KOH}$ $(\geq 86 \%$, Fluka);

Etanol $(\geq 99,8 \%, \mathrm{VWR})$;

2-propanol $(\geq 99,8 \%, \mathrm{VWR})$;

Aceton $(\geq 99,5 \%, \mathrm{VWR})$;

$\mathrm{Na}_{2} \mathrm{SO}_{4}$ (99\%, Alfa Aesar);

$\mathrm{N}_{2}$ gáz $(99,995 \%$, Messer);

Ioncserélt víz (Milli-Q, $\rho=18,2 \mathrm{M} \Omega \mathrm{cm}$ ).

Minden vegyszert további tisztítás nélkül használtunk fel.

A Pt nanorészecskéket az Alkalmazott és Környezeti Kémiai Tanszékről, Dr. Sápi András egyetemi adjunktus kutatócsoportjában szintetizálták és bocsátották rendelkezésünkre.

4.1.2. $\mathrm{CuCrO}_{2}$ szintéziséhez és jellemzéséhez
$\mathrm{Cu}\left(\mathrm{NO}_{3}\right)_{2} \cdot 3 \mathrm{H}_{2} \mathrm{O}$
(99\%, Sigma-Aldrich);
$\mathrm{Cr}\left(\mathrm{NO}_{3}\right)_{3} \cdot 9 \mathrm{H}_{2} \mathrm{O}$
(99\%, Sigma-Aldrich);
$\mathrm{C}_{2} \mathrm{H}_{5} \mathrm{NO}_{2}$
(99,9\%, VWR);
$\mathrm{Cu}_{2} \mathrm{O}$
(97\%, $\leq 7 \mu \mathrm{m}$, Sigma-Aldrich);
$\mathrm{Cr}_{2} \mathrm{O}_{3}$
(Analitikai reagens, Fluka);
$\mathrm{Na}_{2} \mathrm{SO}_{4}$
(99\%, Alfa Aesar);
$\mathrm{NaHCO}_{3}$
(99\%, Reanal);
$\mathrm{N}_{2}$ gáz
(99,995\%, Messer);
$\mathrm{CO}_{2}$ gáz
(99,995\%, Messer);
MilliQ víz
(Milli-Q, $\rho=18,2 \mathrm{M} \Omega \mathrm{cm}$ ).

Minden vegyszert további tisztítás nélkül használtunk fel.

4.1.3. Kétfázisú és ötvözet delafosszitok szintéziséhez és jellemzéséhez
$\mathrm{Cu}\left(\mathrm{NO}_{3}\right)_{2} \cdot 3 \mathrm{H}_{2} \mathrm{O}$,
(99\%, Sigma-Aldrich);
$\mathrm{Cr}\left(\mathrm{NO}_{3}\right)_{3} \cdot 9 \mathrm{H}_{2} \mathrm{O}$,
(99\%, Sigma-Aldrich); 


$\begin{array}{ll}\mathrm{Fe}\left(\mathrm{NO}_{3}\right)_{3} \cdot 9 \mathrm{H}_{2} \mathrm{O} & (99 \%, \text { Sigma-Aldrich); } \\ \mathrm{C}_{2} \mathrm{H}_{5} \mathrm{NO}_{2}, & (99,9 \%, \text { VWR }) ; \\ \mathrm{Na}_{2} \mathrm{SO}_{4}, & (99 \%, \text { Alfa Aesar }) ; \\ \mathrm{NaHCO}_{3}, & (99 \%, \text { Reanal }) ; \\ \mathrm{N}_{2} \text { gáz } & (99,995 \%, \text { Messer }) ; \\ \mathrm{CO}_{2} \text { gáz } & (99,995 \%, \text { Messer }) ; \\ \text { Ioncserélt víz } & (\text { Milli-Q, } \rho=18,2 \mathrm{M} \Omega \mathrm{cm}) .\end{array}$

Minden vegyszert további tisztítás nélkül használtunk fel.

\subsection{Szintézismódszerek}

\subsubsection{Anodizáció}

A félvezető elektródok előállításának számos módja van, azonban a leggyakrabban alkalmazott módszerek általában nagy idő- és energiabefektetést igényelnek. A kutatások során ezért olyan előállítási módokat próbálnak előtérbe helyezni, amelyek gyorsak, valamint szobahömérsékleten is véghezvihetők. Ilyenek lehetnek az elektrokémiai eljárások, amelyek közül anodizációval könnyen lehet nanostrukturált fémoxidokat létrehozni. Ez egy olyan eljárás, amely során a fémoxidnak megfelelő tiszta fémlemezt egy kiválasztott komplexképző elektrolit oldatában elektrokémiailag oxidálva, a komplexképződés és az oxidképződés versengése nanopórusos fémoxid félvezetőt alakít ki [92,93]. Ennek a technikának nagy előnye, hogy a rétegképződés közvetlenül a fém felületéből történik.

$\mathrm{Az}$ anodizáció két- és háromelektródos elrendezésben is megvalósítható. A cella munkaelektródjaként a már előzetesen megtisztított fém funkcionál, míg ellenelektródként egy inert fémet, például platinaelektródot használhatunk. Az eljárás végezhető akár az áramerősség, akár a feszültség szabályozásával. Az előbbinél azonban a feszültség folyamatos változása miatt mellékfolyamatok is végbemehetnek. A tapasztalat szerint a mintákat általálban hőkezelésnek vetik alá annak érdekében, hogy az elkészült rétegek minél inkább kristályosak legyenek, valamint, hogy az előállítás során esetlegesen bekerült szennyeződéseket eltávolítsák.

Ezzel a módszerrel különböző morfológiájú anyagokat lehet elöállítani, amelyek lehetnek például nanopórusos [94], nanoszálas [95,96] vagy nanocsöves [97] szerkezetek. Mivel eltérő körülmények nagyon különböző szerkezeteket eredményeznek, ezért fontos, 
hogy a szintézis körülményeit optimalizáljuk a kívánt struktúra kialakulása érdekében. A kialakuló szerkezetre a következő paraméterek vannak döntő befolyással $[98,99][100]$ :

- az elektrolit $\mathrm{pH}-\mathrm{ja}$,

- víztartalom (nem vizes közegü leválasztás során),

- ellenion anyagi minősége, koncentrációja,

- hőmérséklet,

- a komplexáló anyag,

- az anodizáláshoz alkalmazott feszültség és időtartam,

- az anodizációs feszültség eléréséhez szükséges sebesség.

Számos anyag alkalmazható komplexálóként, de a legtöbbször valamilyen F-tartalmú anyagot használnak. Amennyiben nem alkalmaznánk komplexáló anyagot az anodizáció során, akkor egy kompakt réteg alakulna ki, viszont rendezett nanostruktúra nem. Az oxidképződés lehetséges lépéseit az alábbi egyenletekkel írható le:

$$
\begin{gathered}
\mathrm{M} \rightarrow \mathrm{M}^{\mathrm{z}+}+\mathrm{ze}^{-} \\
M^{z+}+\frac{z}{2} \mathrm{H}_{2} \mathrm{O}=\mathrm{zH}^{+}+\mathrm{MO}_{\bar{z}} \\
\mathrm{M}^{\mathrm{z}+}+\mathrm{z} \mathrm{H}_{2} \mathrm{O} \rightarrow \mathrm{M}(\mathrm{OH})_{\mathrm{z}}+\mathrm{zH}^{+}+\mathrm{M}(\mathrm{OH})_{\mathrm{z}} \rightarrow M O_{\frac{z}{2}}+\frac{z}{2} \mathrm{H}_{2} \mathrm{O}
\end{gathered}
$$

Ezzel a folyamattal párhuzamosan komplexképződés következik be, valamint az ellenelektródon $\mathrm{H}_{2}$ gáz fejlödése tapasztalható [101]:

$$
\begin{gathered}
\mathrm{M}^{\mathrm{z}+}+\mathrm{y} \mathrm{F}^{-} \rightarrow\left[\mathrm{MF}_{\mathrm{y}}\right]^{(\mathrm{y}-\mathrm{z})-} \\
\mathrm{z} \mathrm{H}_{2} \mathrm{O}+\mathrm{z} \mathrm{e}^{-} \rightarrow \frac{z}{2} \mathrm{H}_{2} \uparrow+z \mathrm{OH}^{-}
\end{gathered}
$$

A fém felületén különböző hibahelyeken kezdődik meg az anodizációs folyamat. A komplexképző ágens ezeken a hibahelyeken kezdi el komplexálni az oxidálódó fémet. Az anodizáció előrehaladtával az állandó oxidképződéssel együtt ez a folyamat pórusok kialakulásához, majd pedig azok növekedéséhez vezet (13. ábra). Némely anyagnál a pórusos szerkezet tovább alakul, és jól definiált nanocsövek jöhetnek létre, pl. $\mathrm{TiO}_{2}$ esetében $[102,103]$. 


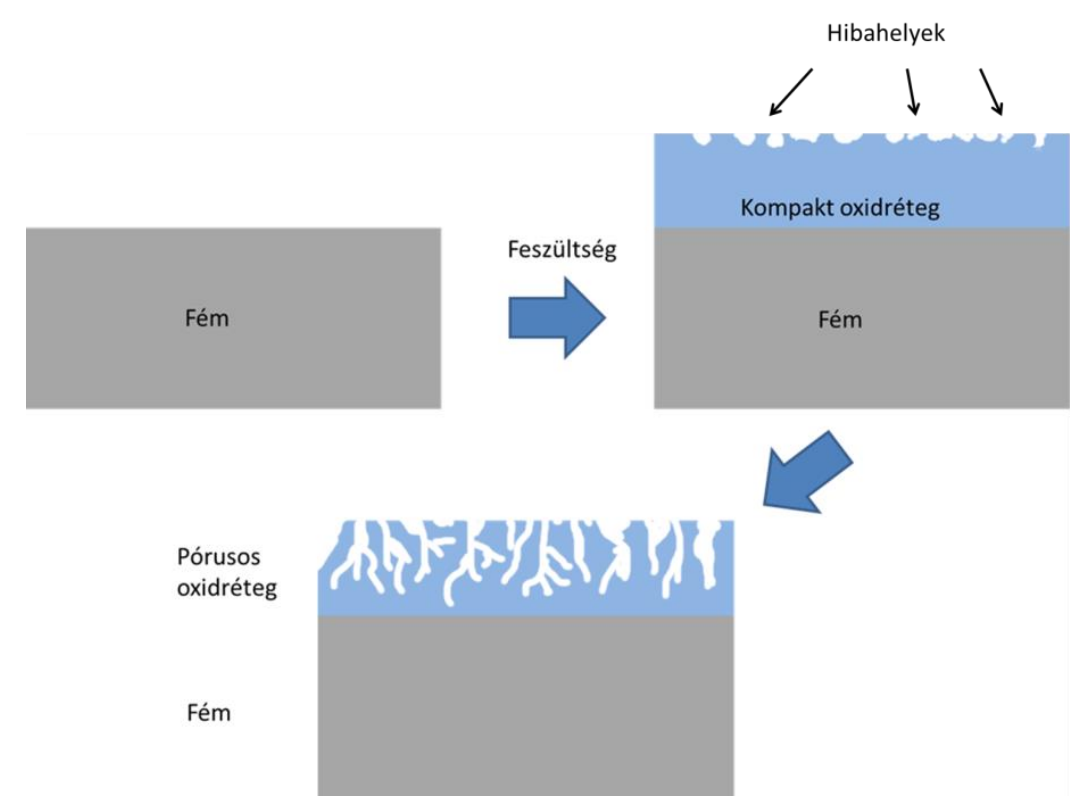

13. ábra: Az anodizáció során végbemenő folyamatok.

Anodizáció során a megszokott elektrokémiai kísérletekhez képest nagy feszültségeket alkalmaznak a megfelelő vastagságú oxidréteg létrehozásához. Nagyobb feszültségek alkalmazásakor vastagabb réteg alakul ki. Az alkalmazott feszültség az elektrolit közegétől függően változhat: amíg vizes közegben $1-30 \mathrm{~V}$ is elegendő lehet, addig szerves közegekben akár 5-150 V között is változhat a szükséges feszültségérték. A szerves közegü szintézis során azért van szükség nagyobb feszültségértékre, mert az ilyen oldatok elektromos vezetése kicsi. A feszültség azért is fontos paraméter, mert a rétegvastagság mellett a pórus átméröjét is befolyásolja, mivel nagyobb feszültség esetén nagyobb az elektrokémiai hajtóerő.

A szakirodalomban gyakran alkalmaznak szerves közegü szintéziseket, mivel rendezettebb szerkezeteket lehet létrehozni bennük. Amennyiben nanocsöveket állítanak elő, azok felszíne simább lesz. Ez azért lehetséges, mert a szerves közegek a víztől eltérő viszkozitással rendelkeznek, illetve hangolható a víztartalmuk. A víz jelenléte nélkülözhetetlen az oxidképződéshez, illetve a képződött komplexált vegyület feloldásához, ami lehetővé teszi a gyorsabb maratási folyamatot. 


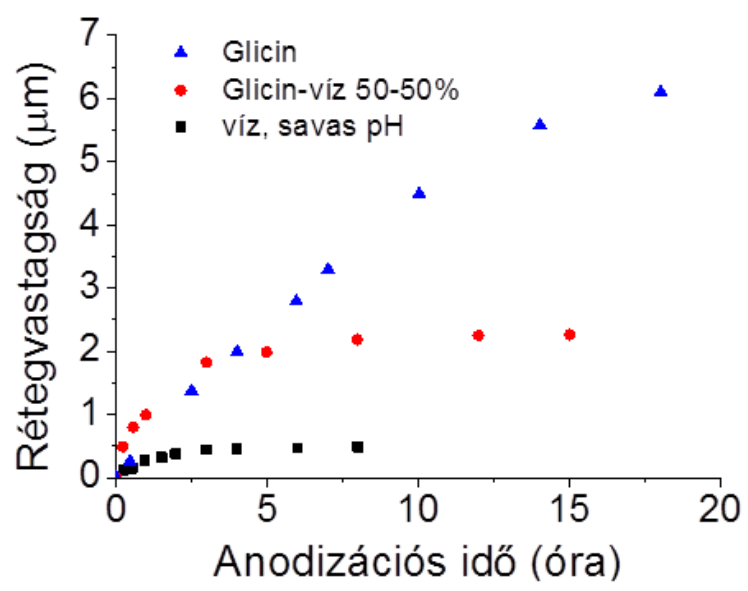

14. ábra: $\mathrm{A} \mathrm{TiO}_{2}$ anodizációja során alkalmazott anodizációs idő és a különböző közegek hatása a rétegvastagságra [101].

\subsection{2. $\mathrm{NiO}$ anodizációs szintézise}

$\mathrm{Az}$ anodizáció előtt a nikkel fóliákat tükörsimára csiszoltunk finomabb érdességü szilícium-karbid csiszolópapír segítségével. Annak érdekében, hogy minden szerves szennyeződést eltávolítsunk a felületről, három különböző oldószerben tisztítottuk a csiszolt lemezeket (egyenként 5 percen keresztül, ultrahangos kádban): acetonban, 2propanolban és ioncserélt vízben.

Az anodizációt kételektródos elrendezésben hajtottuk végre, a Ni fóliát anódként, a $\mathrm{Pt}$ ellenelektródot katódként használva. A nikkel fóliát a szintézis során egy $\mathrm{O}$-gyürüvel szorítottuk le, a fém $2,27 \mathrm{~cm}^{2}$ felületen érintkezett az elektrolittal. Az anodizációt különböző feszültségeken hajtottuk végre, programozható Voltcraft PSP 1803 áramforrás segítségével, valamint a folyamatot egy digitális multiméterrel (Keithley 2000) követtük. A berendezést egy egyedileg készített LaBVIEW programmal vezéreltük.

$\mathrm{Az}$ anodizációt követően a minták felszínéröl a visszamaradt elektrolitot óvatosan lemostuk ioncserélt vízzel, majd a réteget $\mathrm{N}_{2}$ áramban megszárítottuk. Azért, hogy elérjük a kívánt kristályosságú NiO-t, az anodizált mintákat különböző ideig (1-4 óra) különböző hőmérsékleteken (300-600 $\left.{ }^{\circ} \mathrm{C}\right)$ levegő atmoszférában hőkezeltük. A felfütés sebessége $10{ }^{\circ} \mathrm{C} \min ^{-1}$ volt (Thermo Scientific Heraeus K114 kemence).

\subsubsection{Pt nanorészecskék előállítása a $\mathrm{Pt} / \mathrm{NiO}$ rétegekhez}

A különböző méretű nanorészecskék előállításához $\mathrm{NaOH}$-ot és polivinilpirrolidont $\left(\mathrm{M}_{\mathrm{w}}=29000\right)$ oldottak fel etilén-glikolban platina prekurzorral együtt $\left(\mathrm{H}_{2} \mathrm{PtCl}_{6} \cdot \mathrm{xH}_{2} \mathrm{O}\right.$ vagy platina (II) acetilacetonát). Ezt követően a keveréket $160-200{ }^{\circ} \mathrm{C}$ fokra melegítették fel olajfürdőn, és a hőmérsékletet 10 perc és 2 óra közötti ideig tartották argon atmoszférában. 
A Pt nanorészecskéket öt különböző méretben állították elő: 2,0 $\pm 0,4 ; 4,8 \pm 0,7 ; 7,2 \pm 0,8$; $8,6 \pm 1,3$ és 12,3 $\pm 1,4 \mathrm{~nm}$ (15. ábra). A nanorészecskéket a szintézist követően acetonnal csapták le, centrifugálták a kapott terméket, majd etanolban diszpergálták újra. Végül a nanorészecskéket többször átmosták hexánnal, centrifugálták, és használat előtt újra diszpergálták etanolban. A Pt szuszpenziók pontos koncentrációját ICP-MS (Agilent 7700x típusú ICP-MS spektrométer) mérésekkel határoztuk meg [104]. A nanorészecskék föleg gömb alakúak voltak, azonban oktaéderes részecskék is megfigyelhetőek voltak a viszonylag nagyobb méretü nanorészecskéknél.

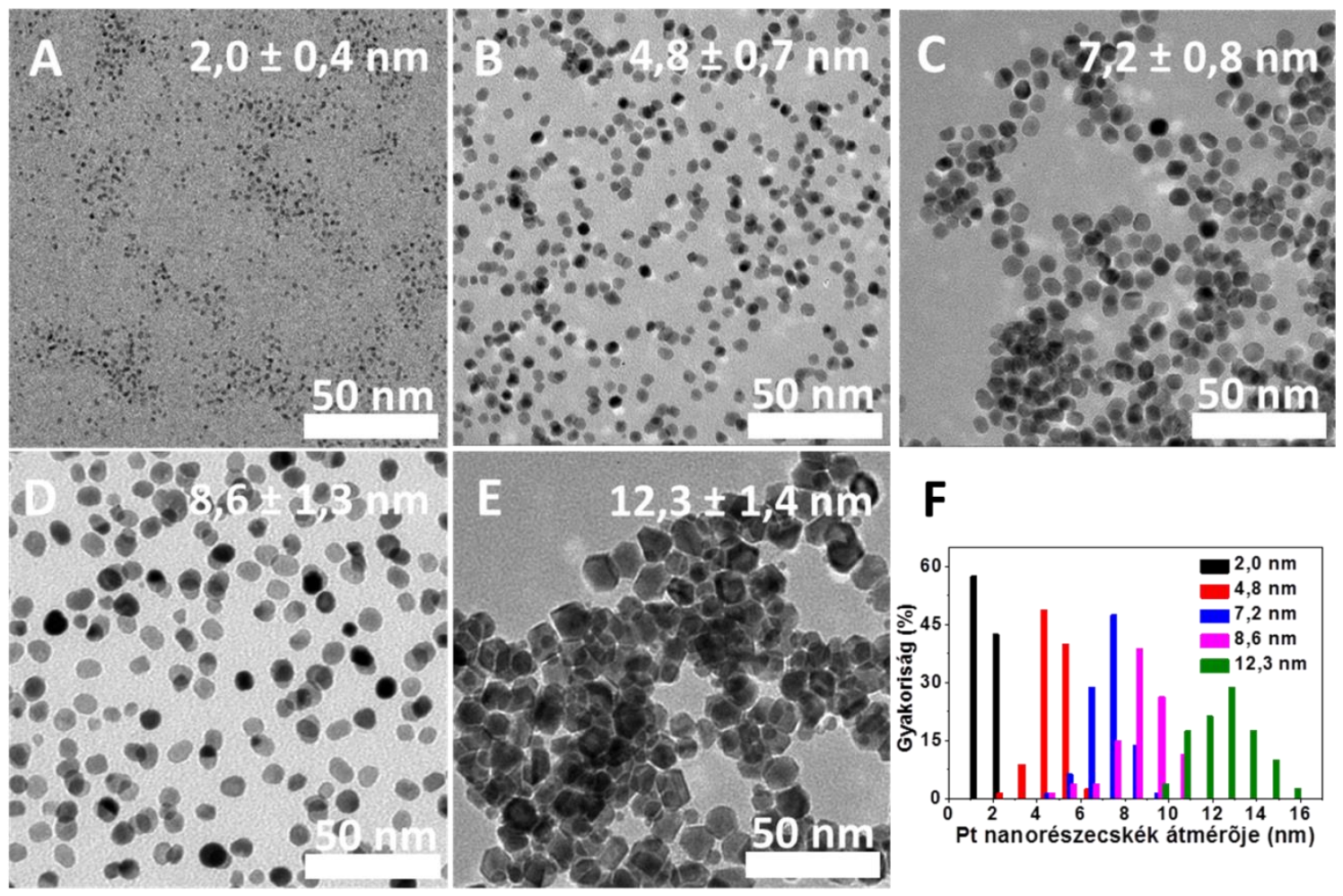

15. ábra: (A-E) A TEM képek a különböző méretű Pt nanorészecskékröl; (F) Az egyes nanorészecskék méreteloszlása.

\subsection{4. $\mathrm{Pt} / \mathrm{NiO}$ réteg kompozit elektródok előállítása}

Az előzőekben készített $\mathrm{NiO}$ mintákat négy darabba vágtuk. A négyből egyet megtartottunk, mint referencia, míg a maradék hármon Pt nanorészecskéket rögzítettünk. A különböző méretü Pt nanorészecskék etanolos szuszpenzióit 60 perc ultrahangozást követően cseppentettük a fözőlapon $65^{\circ} \mathrm{C}$-ra elömelegített $\mathrm{NiO}$ minták felszínére. A kísérleteinket minden méretü $\mathrm{Pt}$ esetén vizsgáltuk a $\mathrm{NiO}$ rétegekre felvitt $\mathrm{Pt}$ mennyiségének hatását (három különböző mennyiség 1,0 - 4,0 $\mu \mathrm{g} \mathrm{cm}^{-2}$ tartományban). Azért, hogy minél jobb legyen a kölcsönhatás a NiO és Pt között, valamint, hogy 
eltávolítsuk a polivinilpirrolidont a Pt felszínéröl, a Pt/NiO kompozitokat $300{ }^{\circ} \mathrm{C}$-on hőkezeltük levegőn, két órán keresztül. A felfütés sebessége $5^{\circ} \mathrm{C} \mathrm{min}{ }^{-1}$ volt.

\subsection{Oldatbelobbantásos szintézis}

Számos módszer ismert félvezetők előállítására, mint például a szol-gél, szilárd fázisú és hidrotermális eljárások. Ezen módszerek azonban nagy energia- és/vagy időbefektetést igénylő eljárások. Az oldatbelobbantásos eljárás (angol szakirodalomban solution combustion synthesis, SCS) azonban egy gyors és energiahatékony szintézismódszer. Ennek lényege, hogy valamilyen fémsót (pl. nitrát, szulfát, karbonát), amely oxidálószerként viselkedik, feloldunk valamilyen szerves üzemanyaggal (pl. glicin, karbamid, hexametiléntetramin), amely redukálószerként viselkedik. Ezt követően az elegyet (enyhén) melegítve az oldószer elpárolog. Amikor a reakcióelegy eléri a két komponens reakciójának lejátszódásához szükséges hőmérsékletet, akkor egy, akár 3000 ${ }^{\circ} \mathrm{C}$-os lánggal járó, önfenntartó, exoterm folyamat megy végbe [105]. A szintézist követően általában szilárd kristályos anyagot kapunk.

Az eljárás előnye, hogy az egyes anyagok a reakció előtt alaposan elkeverednek, így a szintézis végén homogén terméket kapunk. További előnye az eljárásnak, hogy (i) nagyon gyors (néhány percet vesz igénybe), (ii) nagy mennyiségű gáz keletkezik a reakció során, amelynek hatására finom eloszlású, nagy felületü pórusos anyagot kapunk (iii) nem szükséges drága laboratóriumi felszerelés a szintézis elvégezéséhez, (iv) környezetbarát anyagok is használhatók a szintézishez, (v) más eljárásokkal nehezen előállítható, három és négy fémet tartalmazó oxidok is nagy tisztasággal előállíthatóak [106].Azonban meg kell jegyezni, hogy a szintéziselegy térfogata, valamint a szintézishez használt olvasztótégely dimenziói hatással vannak a reakcióra, és ezáltal befolyásolni tudják a végső termék összetételét [107,108].

A lehetséges fémsók közül leginkább a nitrátokat használják annak köszönhetően, hogy a $\mathrm{NO}_{3}{ }^{-}$-nak jó az oxidáló képessége, valamint ezen anyagoknak jó a vízoldhatósága, és alacsony a bomlási hömérsékletük is [109]. A lehetséges üzemanyagok közül legtöbbször karbamidot vagy glicint alkalmaznak. Ez annak köszönhetö, hogy az $-\mathrm{NH}_{2}$ csoportok aktivitása nagyobb, mint az $-\mathrm{OH}$ csoportoknak, és még aktívabb, mint a - $\mathrm{COOH}$ csoportoknak. A karbamid két aminocsoportot tartalmaz, míg a glicin csak egyet. A glicin esetén további előny, hogy tartalmaz egy - $\mathrm{COOH}$ csoportot, ami nem a reaktivitást, hanem a komplexálódást segíti, így javítva a fémsók oldódását [110]. 
A végtermék szerkezete és/vagy felületi tulajdonságai nagyban függenek attól is, hogy milyen üzemanyagot használunk a szintézis során. Aszerint is csoportosíthatjuk a belobbantásos reakciókat, hogy lánggal vagy láng nélkül mennek végbe, amelyek jelentősen különböznek intenzitásukban. A reakciók során különböző gázok, mint pl. $\mathrm{NO}_{2}$, $\mathrm{HNCO}, \mathrm{NH}_{3}, \mathrm{CO}$ stb. keletkezhetnek nagy mennyiségben.

A belobbantásos eljárásokban használt szerves üzemanyag molekuláknak a következő tulajdonságokkal kell rendelkezniük:

- általában vízben oldhatónak kell lennie, azonban szerves oldószerek is alkalmazhatóak a szintézishez.

- komplexáló ágensként kell müködnie. A fém-üzemanyag együtt egy új prekurzort alkothat.

- olvadáspontjának $250{ }^{\circ} \mathrm{C}$ alatt és gyújtási hőmérsékletének pedig $500{ }^{\circ} \mathrm{C}$ alatt kell lennie.

- Az üzemanyag lehetőleg a szintézis alatt teljesen el kell, hogy bomoljon, és nagy mennyiségü gázt kell, hogy termeljen. Ez különösen azért fontos, mert ez a katalizátorok szerkezeti tulajdonságainak javítását eredményezheti [111].

Ha a szintézis során az általában használt karbamidnál vagy hidrazinnál nagyobb molekulatömegü üzemanyagot alkalmazunk, mint például glicin vagy citromsav, akkor a szintézist követően az üzemanyagból esetlegesen szénszennyeződés maradhat vissza a termék felszínén, amelyet csak utólagos hőkezeléssel lehet eltávolítani. A tervezés során a legegyszerübben úgy tudjuk figyelembe venni a visszamaradó szénszennyeződés mennyiségét, hogy megvizsgáljuk az adott üzemanyag oxigén/szén $(\mathrm{O} / \mathrm{C})$ arányát. Ezt az $\mathrm{O} / \mathrm{C}$ arányt az üzemanyag teljes oxidációja során képződő termékek oxigén-, illetve széntartalma alapján lehet kiszámolni. Ezt ábrázolva redukáló vegyérték függvényében, akkor a 16. ábrán látható sorrendet kapjuk. Az oxigén/szén arány ismerete azért különösen fontos mivel csökken a redukáló vegyérték növelésével. Ez alapján arra a következtetésre jutottak, hogy a kis redukáló vegyértékkel rendelkező üzemanyagok (pl. a karbamid) az oxidáló atmoszférának kedveznek a reakció során. Ennek köszönhetően az ilyen anyagoknál kisebb az esély arra, hogy szénszennyeződés maradjon vissza [112].

A belobbantás entalpiája és a redukáló vegyérték közötti lineáris összefüggést vizsgálva (16. ábra betétábrája) meghatározható, hogy egy adott üzemanyagot felhasználva mennyire lesz exoterm a reakció. 
Ahhoz, az oldatbelobbantásos eljáráshoz a pontos sztöchiometriai egyenleteket meg tudjuk adni, számos folyamatot kellene figyelembe venni. Annak érdekében, hogy könnyebben kiszámolhassuk az egyes prekurzorok és termékek sztöchiometriai együtthatóit, jelentős egyszerüsítéseket szoktak alkalmazni. Ilyen egyszerüsítés során például feltételezzük, hogy a fémek az oxidációs számukkal szerepelnek, a hidrogén +1 gyel, a szén +4-gyel, az oxigén -2-vel és a nitrogén 0 -ás vegyértékkel szerepel a számolások során.

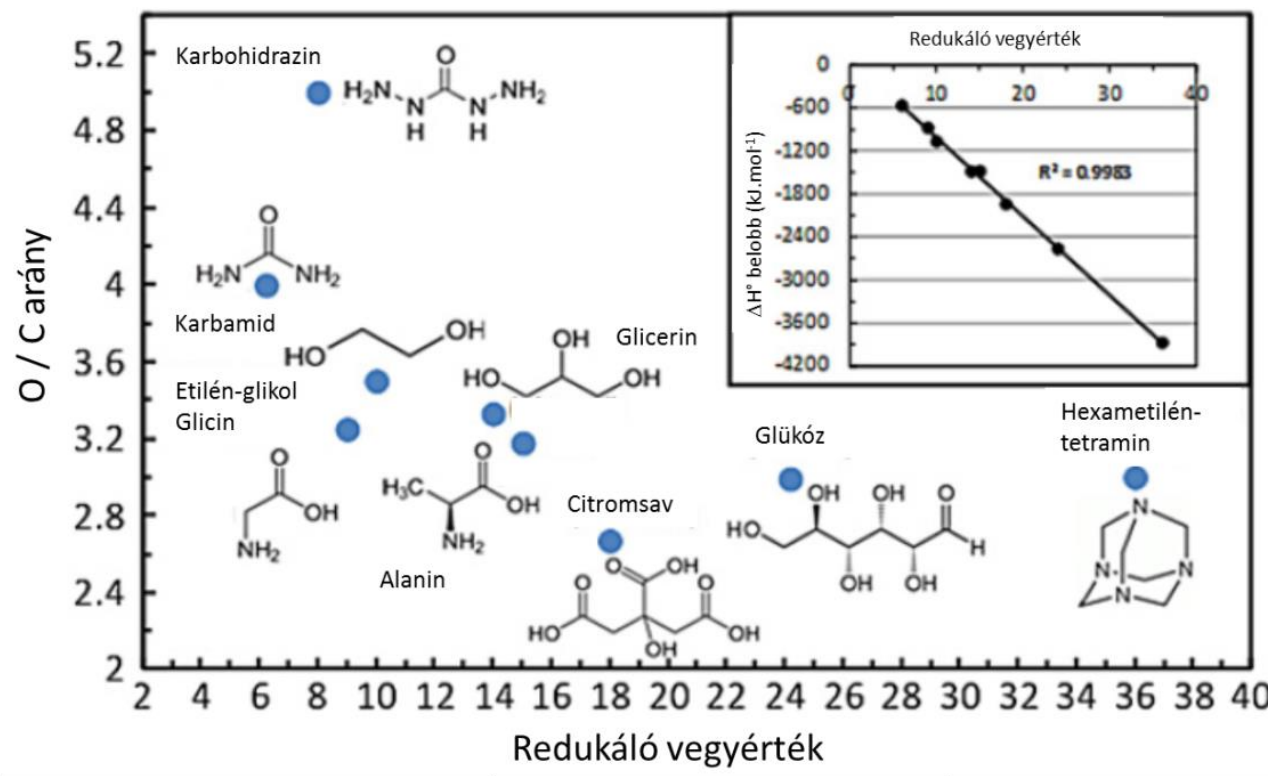

16. ábra: Az oxigén/szén arány a redukáló vegyérték függvényében. A betétábrában az oldatbelobbantási reakció entalpiaváltozása látható a redukáló vegyérték függvényében [111].

Így például a glicin esetén a látszólagos redukáló érték a következőképpen adódik: $\left(\mathrm{NH}_{2} \mathrm{CH}_{2} \mathrm{COOH}\right)(0+2+4+2+4-2-2+1)=+9$. Fémsók esetén az látszólagos oxidáló vegyértéküket hasonlóképpen számolhatjuk, és így megkaphatjuk, hogy a $\mathrm{Cu}\left(\mathrm{NO}_{3}\right)_{2}$-nak az oxidáló értéke -10 és a $\mathrm{Cr}\left(\mathrm{NO}_{3}\right)_{3}$-nak -15 .

Ezt követően használhatjuk az üzemanyag/oxidálószer arány abszolút értékét a 15. egyenlet alapján:

$$
\frac{F}{O}=\frac{\text { Összes vegyértéke az üzemanyagnak }}{\text { Összes vegyértéke az oxidálószernek }}
$$

Ennek az aránynak az ismeretében már rendezhetőek az egyenletek. Azt az arányt tekintjük $\mathrm{F} / \mathrm{O}=1-n e k$, amelynél a szintézis során az egyes reaktánsok sztöchiometrikusan reagálnak. Ennél az aránynál nem szükséges a környezeti $\mathrm{O}_{2}$ jelenléte a reakció lejátszódásához. Amennyiben ez az arány 1-nél nagyobb, akkor üzemanyagban gazdag 
reakcióról, illetve amennyiben 1 alatt van, abban az esetben üzemanyagszegény reakcióról beszélünk. Utóbbi esetben már a környezet oxigénjének jelenléte is szükséges a reakció teljes lejátszódásához. A fenti megfontolásokat figyelembe véve az általunk előállított $\mathrm{CuCrO}_{2}$-ra a sztöchiometriai egyenletet a 16-os egyenlet adja meg:

$9 \mathrm{Cr}\left(\mathrm{NO}_{3}\right)_{3}+9 \mathrm{Cu}\left(\mathrm{NO}_{3}\right)_{2}+26 \mathrm{C}_{2} \mathrm{H}_{5} \mathrm{NO}_{2} \rightarrow 9 \mathrm{CuCrO}_{2}+52 \mathrm{CO}_{2}+65 \mathrm{H}_{2} \mathrm{O}+35,5 \mathrm{~N}_{2}$

Ebben az esetben további egy mol glicint figyelembe kell venni a rendszert leíró egyenletben (25 helyett 26 szerepel az egyenletben), mivel a rendezés alapján oxidációs szám változás következett be. Ezen reakció három különböző lépésben következik be [113]: (i) a $\mathrm{Cu}^{2+}$ és a $\mathrm{Cr}^{3+}$ ionok CuO-t és $\mathrm{Cr}_{2} \mathrm{O}_{3}$-t alkotnak, majd (ii) az oxidok magas hőmérsékleten reagálnak, és $\mathrm{CuCr}_{2} \mathrm{O}_{4}$ spinellt alkotnak, végül (iii) amikor a hőmérséklet $\mathrm{T}$ $=900{ }^{\circ} \mathrm{C}$ fölé emelkedik, akkor a spinell elbomlik $\mathrm{CuCrO}_{2}$-ra és oxigénre (17. egyenlet) [45].

$$
\mathrm{CuCr}_{2} \mathrm{O}_{4}+\mathrm{CuO} \rightarrow 2 \mathrm{CuCrO}_{2}+0,5 \mathrm{O}_{2}
$$

Fontos megjegyezni, hogy ez a levezetés számos egyszerüsítést tartalmaz annak érdekében, hogy a kísérletek elvégzéséhez szükséges számolásokat el tudjuk végezni. A valóságban ez a kép sokkal komplexebb, több mellékreakcióval és a légköri $\mathrm{O}_{2}$ jelenlétével is számolni kell, mint további oxidáns, továbbá különböző összetételü $\mathrm{N}_{\mathrm{x}} \mathrm{O}_{\mathrm{y}}$ gázok is keletkezhetnek.

Ezzel az eljárással állítottak már elő $\mathrm{TiO}_{2}$-ot. $\mathrm{A} \mathrm{TiO}_{2}$ elöállításhoz először a titán izopropoxidot elhidrolizálták, majd az így kapott $\mathrm{TiO}(\mathrm{OH})_{2}$ csapadékot többször átmosták, és tömény salétromsavban feloldották. Így kapták meg a reakcióhoz szükséges Ti( $\left.\mathrm{NO}_{3}\right)_{3}$ prekurzort. Ezt követően többfajta üzemanyaggal (glicin, hexametiléntetramin, oxalildihidrazin) elöállították a $\mathrm{TiO}_{2}$-t. Modell rendszerként a metilénkék bontásához használták fel [114].

Az így elöállított minták fotokatalitikus aktivitását összehasonlították a kereskedelmi forgalomban kapható $\mathrm{TiO}_{2}$-val (Aeroxid P25). Minden oldatbelobbantásos eljárással előállított $\mathrm{TiO}_{2}$ jobban teljesített, mint a kereskedelmi forgalomban kapható minta (17. ábra). Ennek valószínüsíthető oka, hogy egyrészt kisebb $\mathrm{TiO}_{2}$ részecskék keletkeztek (6-9 nm), mint a kereskedelmi mintában (32 nm), és ennek következtében nagyobb felület állt rendelkezésre a metilénkék elbontásához. Másrészt az SCS módszerrel előállított mintáknak kisebb volt a tiltottsáv-szélességük $(2,85-2,98 \mathrm{eV})$, mint a kereskedelmi forgalomban kapható mintáknak (3,1 eV) [114]. 


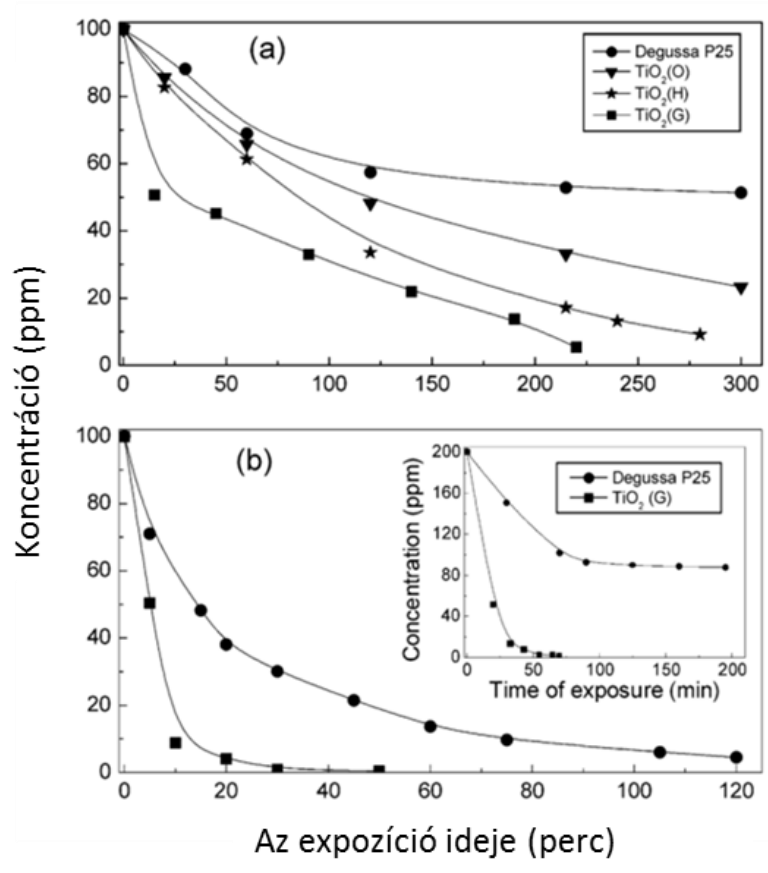

17. ábra: Metilénkék fotokatalitikus bontása az SCS-sel előállított és a kereskedelmi forgalomban kapható $\mathrm{TiO}_{2}$-okon (A) napfény megvilágítás, (B) UV-fény megvilágítás mellett [114].

\subsection{1. $\mathrm{CuCrO}_{2}$ előállítása oldat belobbantásos szintézissel}

A prekurzorok mennyiségét úgy számoltuk ki, hogy a reakció lejátszódását követően

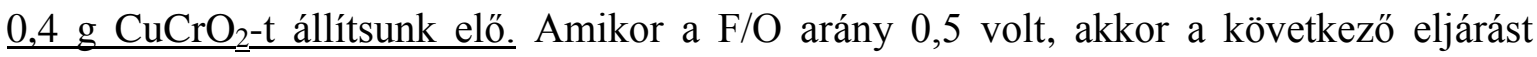
alkalmaztuk: $\mathrm{Cr}\left(\mathrm{NO}_{3}\right)_{3} \cdot 9 \mathrm{H}_{2} \mathrm{O}\left(0,65 \mathrm{~mol} \mathrm{dm}^{-3}\right), \mathrm{Cu}\left(\mathrm{NO}_{3}\right)_{2} \cdot 3 \mathrm{H}_{2} \mathrm{O}\left(0,65 \mathrm{~mol} \mathrm{dm}^{-3}\right)$ és

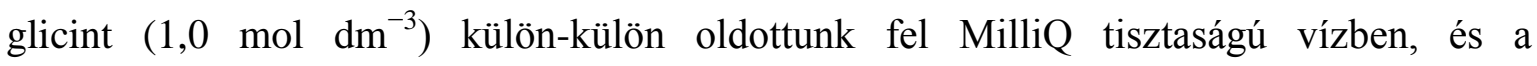
reakcióelegy össztérfogata $4 \mathrm{~cm}^{3}$ volt. Az oldatokat egy kerámia olvasztótégelybe (40 $\mathrm{mm}$ felső átmérőjü és $32 \mathrm{~mm}$ magas) öntöttük össze, majd egy előre melegített főzőlapra ( $\mathrm{T}=$ $350{ }^{\circ} \mathrm{C}$ ) helyeztük, ezt követően a szintézis öt perc alatt végbement. Egy titánhálót feszítettünk az olvasztótégely fölé annak érdekében, hogy megakadályozzuk az anyag szétszóródását a szintézis során. A szintézist követően 85-90\%-os kitermelést értünk el. A mintákat finom porrá őröltük egy dörzsmozsárban, majd desztillált vízzel mostuk az esetlegesen el nem reagált, visszamaradt fémsók eltávolítása céljából. Ezt követően a mintákat szárítószekrényben tömegállandóságig szárítottuk $100{ }^{\circ} \mathrm{C}$-on. Bizonyos esetekben a mintákat Thermolyne 21100 csőkemencében hökezeltük, 400-700 ${ }^{\circ} \mathrm{C}$ tartományon, egy órán keresztül, Ar atmoszférában (Messer, 99,999\%). 


\subsection{2. $\mathrm{A} \mathrm{CuFeO}$, ötvözetek és kétfázisú delafosszit kompozitok elektródok kialakítása}

Az elektrokémiai mérésekhez a szintetizált porokat porlasztva fújás segítségével rögzítettük üvegszén (glassy carbon, GC) elektródokon. Mivel a $\mathrm{CuFeO}_{2}$, az ötvözet, valamint a kétfázisú kompozit kevésbé tapadt az elektród felszínéhez, mint a $\mathrm{CuCrO}_{2}$, ezért a minta felviteléhez olyan szuszpenziót $\left(\mathrm{c}=5 \mathrm{mg} \mathrm{cm}^{-3}\right)$ készítettünk, amelyben izopropanol-víz (50:50 V/V\%) elegyéhez nafion diszperziót adtunk (125 $\mu$ l-t 10 ml-hez). Ezeket a szuszpenziókat 60 percig ultrahang segítségével homogenizáltuk, majd az előbb leírt módon vittük fel a GC elektródok felszínére (kialakított felület: $1 \mathrm{~cm}^{2}$ ). Több ciklusban vittük fel a mintákat 0,$3 ; 0,7 ; 1,0 ; 3,0 \mathrm{mg} \mathrm{cm}^{-2}$ felületi mennyiséget kialakítva. Az elkészítést követően minden elektródot $\mathrm{T}=700^{\circ} \mathrm{C}$-on hőkezeltünk Ar atmoszférában.

\subsection{Anyagszerkezeti vizsgálati eljárások}

\subsubsection{Diffúz reflexiós UV-látható spektrometria}

Diffúz reflexiós spektrofotometriával szilárd minták fényelnyelési sajátságai vizsgálhatóak. Mérés előtt mindig egy referenciaanyag spektrumát kell felvenni, amelynek a vizsgált tartományban teljesen reflektál a felülete. Ehhez általában $\mathrm{BaSO}_{4}$-ot vagy egy csiszolt fémlemezt, polírozott Pt lemezt alkalmaznak. Az általunk vizsgált minta ehhez képest mért reflektanciája az anyag fényelnyelésével hozható összefüggésbe. A diffúzan visszaverődő fény összegyüjtésére integráló gömbök használhatóak, melyek további előnye, hogy úgy vannak kialakítva, hogy a minta felületéről a teljesen visszaverődő fényt is kizárják.

Félvezetők tiltottsáv-szélességének pontos meghatározására használható a Tauc ábrázolásmód. A Tauc ábrázolás meghatározható mind az abszorbancia, mind a reflektancia spektrumból. Előbbinél azonban tudni kell az abszorpciós koefficienst $(\alpha)$. Amennyiben viszont a reflektancia értékeket (R) az egyenlet alapján Kubelka-Munk függvénnyé $(\mathrm{F}(\mathrm{R}))$ alakítjuk, ez az érték arányos lesz az abszorpciós koefficiensével $(\alpha)$ $[115,116]$.

$$
\begin{gathered}
F(R)=\frac{(1-R)^{2}}{2 R} \\
(F(R) h v)^{1 / n}=A\left(h v-E_{g}\right)
\end{gathered}
$$

Ezt követően ábrázolva az $(F(R) h v)^{1 / n}$ értéket a $h v$ függvényében a kapott függvény meredeken csökkenő szakaszára illesztett egyenes, valamint az alapvonalra illesztett egyenes metszetéből határozható meg az anyag tiltottsáv-szélessége. Erre azért van szükség, mert a diffúz reflexiós spektrumok rendelkeznek egy alapvonallal, amely miatt a 
származtatott görbék eltolódnak és így a tengelymetszet nem lesz pontos. A n értéket befolyásolja, hogy tiltott vagy megengedett, illetve, hogy direkt vagy indirekt átmenet jellemző az adott félvezetőre. Az $n=1 / 2$ érték direkt átmenetet, míg az $n=2$ érték indirekt átmenet jelent.

\subsubsection{Röntgendiffraktometria}

A röntgendiffrakciós szerkezetvizsgálat (XRD) az egyik legfontosabb roncsolás mentes módszer a legkülönbözőbb anyagok (folyadékok, porok, szilárd, tömbi minták) kristályszerkezetének meghatározásához. Alapja az anyag és a röntgensugár kölcsönhatása. A röntgensugarak kristályos anyagokon áthaladva elhajolnak (diffraktálódnak), amennyiben hullámhosszuk összemérhető a rácssíkok közötti távolsággal. A szabályos kristályrácson erősítés csak kitüntetett irányokban jelentkezik, egyéb irányokban kioltás tapasztalható. Az erősítés geometriai feltételét a Bragg-féle egyenlet adja meg. A Braggféle egyenlet fejezi ki, hogy milyen összefüggés áll fenn a röntgensugár hullámhossza $(\lambda)$, a rácssíkok közötti távolság $(d)$ és a diffrakciós szög $(\theta)$ között [117]:

$$
n \lambda=2 d \sin \Theta
$$

Az egyenletben $n$ a diffrakció rendjét jelöli. A felvett diffrakció helye függ a röntgenforrás fajtájától. A minőségi információ mellett az anyagot alkotó fázisok aránya is meghatározható. Ehhez az úgynevezett Rietveld felbontást lehet alkalmazni, amely az összes komponens egyedi diffraktogrammját egyszerre figyelembe véve illeszti meg a felvett diffraktogrammot, és az intenzitás arányok alapján megmondható az egyes fázisok aránya.

A röntgendiffraktogrammokat egy Rigaku Miniflex II készülékkel rögzítettük. A NiO esetén az alkalmazott tartomány $2 \theta=20-80^{\circ}$, a delafosszit szerkezetủ mintáknál a $2 \theta=10-80^{\circ}$ volt. Minden esetben $2 \%$ perc pásztázási sebességet alkalmaztunk, és röntgenforrásként egy Cu-katódot $(\lambda=1,5406 \quad \AA)$ használtunk. A Rietveld szerkezetfinomításhoz GSAS [118] programot használtunk az EXPGUI [119] grafikus felülettel.

\subsubsection{Fajlagos felület meghatározás}

Szilárd anyagok fajlagos felülete valamely gáznak a felületen létrejött fizikai adszorpciója és a felületen monomolekulás réteget képező gáz-adszorbátum mennyiségének mérése alapján határozható meg. A fizikai adszorpciót a gáz-adszorbátum molekulái és a vizsgált minta felülete közti másodlagos kölcsönhatások (van der Waals-erők) hozzák létre. Az 
adszorbeált gáz mennyiségét meghatározhatjuk tömeg szerinti, térfogatos vagy folyamatos áramlásos módszerrel. Az adszorpciós valamint deszorpciós izotermák vizsgálatából az anyag fajlagos felülete meghatározható.

A $\mathrm{CuCrO}_{2}$ minták felületét egy Quantachrome Nova 2000 E típusú készülékkel vizsgáltuk. A $\mathrm{N}_{2}$ adszorpciós/deszorpciós izotermáit a BET egyenlettel értékeltük ki.

\subsubsection{Fotoelektron spektroszkópia}

Az elektród anyagának felszíni összetételét és az azt alkotó elemek oxidációs állapotát fotoelektron spektroszkópiával (XPS) vizsgáltuk. Az XPS egy érzékeny felületvizsgáló módszer, mely a vizsgált anyag legfelső 1-10 nm tartományáról ad információt. A röntgen fotoelektron spektrumokat egy PHOIBOS 150 MCD 9 analizátorral felszerelt SPECS készülékkel rögzítettük. A spektrum FAT (Fixed Analyser Transmission), azaz állandó analizátor átviteli módban rögzítettük. A minta ionizációját egy kettős anódú röntgencső szolgáltatta $(\mathrm{Al} \mathrm{K} \alpha \mathrm{h} v=1486,6 \mathrm{eV})$. Az energiaskála kalibrációját a C 1s komponensének kötési energiáját alapul véve végeztük, amelyet a felületi széntartalmú szennyeződéseknek megfelelö 285,0 eV-ra állítottak. Az XP spektrumok felvételéhez a gyártótól kapott (SpecsLab2), míg a kiértékeléshez és ábrázolásához az erre a célra fejlesztett CasaXPS, valamint Origin 8.6 szoftvereket használtuk.

\subsubsection{Raman spektroszkópia}

A Raman spektroszkópia során nem polarizált, monokromatikus fényt használunk a vizsgálandó anyag gerjesztésére, és a rezgési módok változását követjük nyomon. A Raman spektroszkópiai vizsgálatokat egy DXR Raman mikroszkóppal végeztük el. A mérések során 532 nm-es gerjesztő lézert használtunk. A mintáink vizsgálatában az optikai mikroszkópon a 10x nagyítású objektívet használtuk. A lézer teljesítménye $10 \mathrm{~mW}$ volt a $\mathrm{NiO}$ minták esetén, és $3 \mathrm{~mW}$ a $\mathrm{CuCrO}_{2}$ tartalmú mintáknál.

\subsubsection{Infravörös spektroszkópia}

Az infravörös spektroszkópia és a Raman-spektroszkópia is a rezgési módokat vizsgáló módszer. Az infravörös fény energiája olyan tartományba esik, mint a molekulák rezgési és forgási tartománya. Az 500-1500 $\mathrm{cm}^{-1}$ tartomány ujjlenyomat-szerủen az adott anyaghoz rendelhető. Az IR spektroszkópia a Raman spektroszkópiát kiegészítő módszer, melynek segítségével további információkat nyerhetünk az adott rendszerről. Az infravörös spektrumokat egy a Bio-Rad Digilab Division FTS-65A/896 Fourier transzformációs berendezéssel vettük fel, ATR feltéttel (Harrick's Meridian ${ }^{\circledR}$ SplitPea single reflection 
diamond attenuated total reflectance). Minden spektrumot 400 és $4000 \mathrm{~cm}^{-1}$ között rögzítettünk, $4 \mathrm{~cm}^{-1}$ optikai felbontás és 256 interferogram átlagolása mellett.

\subsubsection{Transzmissziós elektronmikroszkópia (TEM)}

A TEM olyan mikroszkóp, amely egy elektronsugár-nyalábot használ a megfigyelendő tárgy kétdimenziós leképezéséhez. Ez a berendezés a mintán áthaladt sugárnyalábot detektálja. A mintát egy nagyon vékony, rostélyra feszített hártyára, az úgynevezett gridre kell felvinni. Ezen mérésekből az elkészített részecskék morfológiáját vizsgáltuk, valamint az elkészített képekből meghatároztuk a részecskeméret eloszlásokat.

A TEM felvételeket egy FEI Tecnai ${ }^{\mathrm{TM}} \mathrm{G}^{2} 20$ típusú berendezéssel készítettük. Mintáinkat az Electron Microscopy Sciences cég által gyártott CF200-Cu típusú rézre feszített szénhártyás rácson (griden) mértük.

\subsubsection{Pásztázó elektronmikroszkópia (SEM)}

A TEM-hez hasonlóan ez a berendezés is elektronsugár-nyalábot használ, amely pásztázza a felszínt, miközben a minta és az elektronnyaláb közötti kölcsönhatásokat detektáljuk. A SEM felvételekből a kialakult rétegek felszíni morfológiáját a $\mathrm{CuCrO}_{2}$, kétfázisú és az övezetek oxidoknak, valamint az anodizált $\mathrm{NiO}$ minták pórusméret eloszlását tudtuk meghatározni. A SEM felvételeket, valamint a minta elemösszetételének meghatározására irányuló elektrondiffraktrometriás (EDX) méréseket a SZTE TTIK Elektronmikroszkóp Laboratóriumában, egy Hitachi S-4700 típusú téremissziós pásztázó elektronmikroszkóppal vettük fel, 10 kV gyorsítófeszültség mellett. 


\subsection{Elektrokémiai eljárások}

\subsubsection{Lineáris (foto)voltammetria}

A lineáris voltammetria lényege az, hogy két potenciálérték között időben lineárisan változtatjuk a munkaelektród potenciálját, és mérjük az áthaladó áram erősségét, így vizsgálva az adott potenciáltartományon lejátszódó elektrokémiai folyamatokat.

A potenciál kezdeti értékét úgy állítjuk be, hogy ott még elektrokémiai reakció ne játszódjon le, majd ezt követően állandó sebességgel változtatjuk a másik határértékig, miközben regisztráljuk az áramot. Amennyiben a mért áram pozitív előjelü (anódos áram), azt valamely, az elektródon rögzített vagy az oldatban lévő komponens oxidációjához rendelhetjük, míg negatív áramok esetén elektrokémiai redukció lejátszódására következtethetünk. A lineáris voltammogramon megfigyelhető csúcsokkal, illetve a mért áramerősség értékekkel fontos információkat szerezhetünk az adott rendszer redoxi tulajdonságairól.

Az elektród megvilágításának szakaszos megszakításával egyszerre végezhetünk megvilágítás melletti, illetve anélküli méréseket az adott mintán. Így egyszerre kapunk információt a sötétben és a megvilágítás hatására végbemenő folyamatokról. A megvilágítás mellett, illetve annak hiányában mért áramerősségek különbsége adja meg a fotoáram nagyságát.

$\mathrm{Az}$ elektrokémiai mérés során referenciaként $\mathrm{Ag} / \mathrm{AgCl} 3 \mathrm{M} \quad \mathrm{NaCl}$ elektródot alkalmaztunk. Minden alkalmazott potenciálértéket átszámoltunk a $\mathrm{pH}$ független, reverzíbilis hidrogén elektródra a következő összefüggés segítségével:

$$
E(\mathrm{RHE})=E_{\mathrm{Ag} / \mathrm{AgCl}}+0.059 \mathrm{pH}+E^{\circ} \mathrm{Ag} / \mathrm{AgCl}
$$

ahol a $E_{\mathrm{Ag} / \mathrm{AgCl} / 3 \mathrm{M} \mathrm{NaCl}}^{o}=0,210 \mathrm{~V} 25{ }^{\circ} \mathrm{C}$-on, és $E_{\mathrm{Ag} / \mathrm{AgCl}}$ a munkaelektród referencia elektróddal szemben mért potenciálja.

Méréseinket $\mathrm{NiO}$ minták esetén $0,2 \mathrm{M} \mathrm{Na}_{2} \mathrm{SO}_{4}$-ban $\mathrm{O}_{2}$-el vagy $\mathrm{N}_{2}$-el telített oldatban végeztük. $\mathrm{O}_{2}$ jelenlétében $-0,1 \mathrm{~V}-+0,6 \mathrm{~V}$ potenciáltartományon (vs. RHE), $\mathrm{N}_{2}$ atmoszférában $-0,4 \mathrm{~V}-+0,6 \mathrm{~V}$ potenciáltartományon $2 \mathrm{mV} \mathrm{s}^{-1}$ pásztázási sebesség mellett vizsgálódtunk.

$\mathrm{CuCrO}_{2}, \mathrm{CuFeO}_{2}$, valamint az ötvözet és kétfázisú mintákat mind $\mathrm{CO}_{2}$-al telített $0,1 \mathrm{M}$ $\mathrm{NaHCO}_{3}$ oldatban, valamint $\mathrm{N}_{2}$-al telített $0,1 \quad \mathrm{M} \mathrm{Na}_{2} \mathrm{SO}_{4}$-ban mértük $-0,4 \mathrm{~V}-+1,0 \mathrm{~V}$ potenciáltartományon $2 \mathrm{mV} \mathrm{s}^{-1}$ pásztázási sebesség mellett. 
A mérések során különböző fényforrásokat alkalmaztunk. UV fényforrásként 300 W-os Hg-Xe lámpát (Hamamatsu L8251), míg napfény szimulátorként Newport LCS100 lámpát alkalmaztunk. A fényforrások az elektródtól $5 \mathrm{~cm}$-re voltak elhelyezve (a fény intenzitás az UV fényforrás esetén $0,69 \mathrm{~W} \mathrm{~cm}^{-2}$, látható esetben $0,2 \mathrm{~W} \mathrm{~cm}^{-2}$ ). A fotovoltamogrammok felvétele során a fényt periodikusan megszakítottuk $(0,1 \mathrm{~Hz})$.

\subsubsection{Ciklikus voltammetria}

A ciklikus voltammetria (CV) az egyik legfontosabb, a redoxi tulajdonságok jellemzésére alkalmas elektrokémiai módszer. A módszer lényege, hogy két végérték között időben lineárisan változtatjuk a munkaelektródra kapcsolt potenciált háromszög függvény szerint, és mérjük az áthaladó áram erősségét. A ciklikus voltammogramon megfigyelhető csúcsok, illetve a mért áramerősség értékek segítségével fontos információkat szerezhetünk az adott elektród redoxi tulajdonságairól.

A különböző $\mathrm{NiO}$ réteget $\mathrm{N}_{2}$-el telített $0,2 \mathrm{M} \mathrm{Na}_{2} \mathrm{SO}_{4}$ oldatban $50 \mathrm{mV} / \mathrm{s}$ pásztázási sebesség mellett vizsgáltuk -0,2 - +1,6 V vs. RHE potenciál tartományon. Minden esetben ötször pásztáztuk végig a tartományt és az utolsó pásztázás eredményét ábrázoltuk.

\subsubsection{Kronoamperometria - hosszú idejü mérések}

A fotoelektrokémiai viselkedés jellemzésére egy másik lehetséges módszer a megvilágítással kombinált kronoamperometria alkalmazása lehet, mivel itt állandó körülmények között tudjuk vizsgálni az adott rendszert. Ennek lényege, hogy a vizsgálandó mintát egy adott potenciálon polarizáljuk, majd megvilágítjuk, és mérjük az eközben áthaladó áram nagyságát. Ezt a módszert egy in-situ termékdetektálással kombinálva képesek vagyunk arra, hogy információt nyerjünk az elektródanyag stabilitásáról, valamint a keletkező termékekről mind a gáz, mind a folyadékfázisban. Amennyiben a mérés során a megvilágítást megszakítjuk, akkor - mint a lineáris fotovoltammetria esetén - információt nyerhetünk az anyag (foto)elektrolízise során végbement változásokról (pl. sötét áram növekedés, fotoáram csökkenés).

A kronoamperometriás mérések során egy kvarc ablakos kétterü cellát alkalmaztunk. A cellatereket egy Nafion 117 membránnal választottuk el annak érdekében, hogy csak proton transzfer valósulhasson meg, és a képződő termékek ne zavarják az ellentétes elektródon végbemenő folyamatot. 


\subsubsection{Elektrokémiai impedancia spektroszkópiás (EIS) mérések}

Az impedancia spektroszkópia során az elektródot egy adott potenciálon polarizáljuk, majd erre szuperponálva egy szinuszosan váltakozó perturbáló feszültséget mérjük az áram nagyságát és frekvenciáját. A perturbálójel frekvenciáját széles tartományon változtatva rögzítjük az impedancia spektrumot. Ha vizsgált rendszer lineárisan viselkedik, akkor az áramváltozás pont ugyanolyan frekvenciájú lesz, mint a potenciál változása, azonban az áram nagysága és fázisa nem feltétlenül lesz ugyanakkora. Ezzel a módszerrel meghatározható egy adott anyag sima-sáv potenciálja, töltésátviteli ellenállása, valamint a határfelületen kialakuló kettősréteg kapacitása.

A mérésekhez egy zárt elektrokémiai cellát alkalmaztunk, amelyben 1,0 $\mathrm{M} \mathrm{Na}_{2} \mathrm{SO}_{4}$ oldatot használtunk a $\mathrm{NiO}$ minták esetén és $0,1 \mathrm{M} \mathrm{NaHCO}_{3}$ oldatot a $\mathrm{CuCrO}_{2}$ minták esetén.

A NiO minták esetén az EIS mérések elött öt ciklikus voltammogramot vettünk fel -0,2 $\mathrm{V}-+1,6 \mathrm{~V}$ potenciál tartományon. $50 \mathrm{mV} / \mathrm{s}$ pásztázási sebességet használtunk annak érdekében, hogy a pórusos elektród átnedvesedjen, valamint, hogy meg tudjuk határozni a Pt nanorészecskék elektrokémiailag aktív felszínének nagyságát. Minden impedancia spektrumot két potenciálon rögzítettünk $(\mathrm{E}=+0,6 \mathrm{~V}$ és $\mathrm{E}=+1,2 \mathrm{~V}), 10 \mathrm{~Hz}$ és $0,1 \mathrm{MHz}$ frekvenciatartományon szinuszos gerjesztő jelet használva (10 mV RMS amplitúdó).

A $\mathrm{CuCrO}_{2}$ esetén az elektrolitot 20 percig $\mathrm{Ar}$ gázzal buborékoltattuk. A sima-sáv potenciál meghatározásához Mott-Schottky analízist végeztünk $(\Delta E=0,05 \mathrm{~V}$ lépésköz, $E$ $=+0,6 \mathrm{~V}-+1,2 \mathrm{~V}$ (vs. RHE)), $1 \mathrm{~Hz}-0,1 \mathrm{MHz}$ frekvenciatartományon, szinuszos gerjesztőjelet használva (10 mV RMS amplitúdó).

\subsubsection{Kvantumhatásfok (IPCE) mérések}

Az IPCE az egyik legfontosabb jellemzési eljárás a fotoelektrokémiai módszerek közül. Azt mutatja meg, hogy a beeső fotonfluxus mekkora része alakul át fotoárammá különböző hullámhosszakon. Az IPCE mérés során a fotoelektrokémiai tulajdonságokat meghatározó három alapvető folyamat együtteséről kapunk információt [120]:

- Foton elnyelése - az elektron-lyuk párok keletkezése a beeső foton fluxus hatására,

- a fotogenerált töltéshordozók vándorlása az elektród/elektrolit határfelülethez,

- és a töltéshordozók átlépése a határfelületen az oldatba. 


$$
\text { IPCE }=\frac{\text { A fotoelektronok fluxusa }}{\text { A beeső fény fluxusa }} \times 100 \%
$$

$\mathrm{Az}$ az IPCE értékeket kronoamperometriás mérések során kapjuk. Egy p-típusú félvezető elektródra egy olyan állandó negatív potenciált kapcsolunk (n-típus eseténpozitív potenciált), amelyen a vizsgált elektródon nem játszódik le mellékreakció, azonban kellően nagy fotoáramok mérhetőek, majd elektródot különböző hullámhosszúságú fénnyel megvilágítjuk. A 22. egyenlet azt írja le, hogy az IPCE megfelel annak a hányadosnak, amelyet a fotoelektronok fluxusának és a beeső fény fluxusának hányadosaként adhatunk meg. Elöbbit a kronoamperometriás görbéken mért fotoáramokból, míg utóbbit az alkalmazott fényforrás kalibrált fényteljesítményéből tudjuk számolni. Az általunk használt elrendezésében a kalibrálásához minden mérés előtt egy Si detektort használtunk.

Az IPCE mérésekből meghatározható legfontosabb paraméterek:

- A hullámhossz tartomány, amelyen a minta fotoaktív.

- A fotoelektrokémiai folyamat hatásfoka, amit a keletkezett fotoelektronok fluxusa és a beérkező fotonok fluxusának hányadosaként adunk meg különböző hullámhosszanként,

- A tiltottsáv-szélesség meghatározása, amennyiben egy lineáris illesztést végzünk az IPCE görbe levágási szakaszára.

- A teljes napfény elektronná való alakításának hatásfoka, amelyet az IPCE görbe integrálásából kaphatunk meg a napfény spektrumát felhasználva.

Az IPCE mérésekhez a Newport által gyártott kvantum hatékonyságmérő elrendezést (QEPVSI-B) használtunk egyterü kvarcablakos cellában, három elektródos elrendezésben. Két hullámhossztartományt alkalmaztunk attól függően, hogy milyen volt az adott félvezető tiltottsáv-szélessége: a) 250-500 nm közötti tartomány a NiO, Pt/NiO esetén és b) 300-600 nm közötti tartomány $\mathrm{CuCrO}_{2}$ esetén. A felbontást $\Delta \lambda=10 \mathrm{~nm}$-en tartottuk. $\mathrm{A}$ méréseket szén-dioxiddal telített $0,1 \mathrm{M} \mathrm{NaHCO}_{3}$-ban vagy argonnal telített $0,1 \mathrm{M} \mathrm{Na}_{2} \mathrm{SO}_{4}$ ban is elvégeztük.

\subsection{Termékdetektálás}

\subsubsection{NMR spektroszkópia}

A mágneses magrezonancia spektroszkópia (NMR) alapelve, hogy a mágneses térben lévő atommagok rezonancia révén rádiófrekvenciás sugárzást nyelnek el. Ezzel a módszerrel 
elsősorban az atommagokat tudjuk vizsgálni, de mivel a magokra az azokat körülvevő elektronok és a többi atom is hatással van, ezért a kémiai kötésekről és a molekulák szerkezetéről is információt ad.

A $\mathrm{CO}_{2}$ átalakítás eredményeképpen keletkező termék minőségi és mennyiségi analízisére NMR vizsgálatokat végeztünk, amelyek során egy Bruker Avance Neo 500-as készüléket használtunk. A $450 \mu \mathrm{l}$ mintához $50 \mu \mathrm{l} \mathrm{D}_{2} \mathrm{O}$-t (nehézvíz) kevertünk. Az $1 \mathrm{D}{ }^{1} \mathrm{H}$ spektrumot úgy rögzítettük, hogy a víz jelét minden esetben WATERGATE vízelnyomási pulzusszekvenciával nyomtuk el.

\subsubsection{Gázkromatográfia}

Gázfázisú minták összetételének vizsgálatának az egyik legelterjedtebb módja a gázkromatográfia használata. A gázminták egy kolonnán haladnak át, amelyen elkülönülnek és a detektorra érkezve észlelhetőek. A kolonnán való áthaladás ideje (retenciós idő, $t_{R}$ ) jellemző az anyagi minőségre. $A$ detektált jel arányos az anyagmennyiséggel, így egy kalibrációt követően minőségi és mennyiségi információt is tudunk kapni a gáz összetételéről. Ez a detektálási módszer különösen előnyös, amennyiben olyan detektorokat használunk, amelyek nagy érzékenységgel egyszerre képesek mérni pl. a $\mathrm{H}_{2}-\mathrm{t}, \mathrm{N}_{2}-\mathrm{t}, \mathrm{O}_{2}$ - $\mathrm{t}$ valamint a szénhidrogéneket. Ilyen detektor pl. a Barrier Ionization Discharge (BID) detektor.

A gázfázisú detektálás egy Shimadzu GC-2010 Plus gázkromatográffal történt, amely egy BID detektorral volt felszerelve. A szétválasztáshoz Shin Carbon ST kolonnát használtunk. A hosszú távú mérés során a mintavétel 30, 60, 90, 120, 180 és 240 perc után történt. A detektáláshoz használt paraméterek a következők voltak: fütési program: $T_{\text {start }}=$ $35^{\circ} \mathrm{C}(2,5$ perc $), \Delta T=20^{\circ} \mathrm{C}$ perc ${ }^{-1}, T_{\text {vég }}=270{ }^{\circ} \mathrm{C}(3$ perc $)$; injektálási hőmérséklet: $\mathrm{T}=150$ ${ }^{\circ} \mathrm{C}$. A vivőgáz lineáris sebességét a nyomás szabályozta, $p_{\text {start }}=250 \mathrm{kPa}(2,5$ perc $), \Delta p=15$ $\mathrm{kPa}$ perc $^{-1}, \mathrm{p}_{\text {vég }}=400 \mathrm{kPa}(7,5$ perc) ; split arány: 10. A vivőgáz hélium volt (Messer, 99,9999\% tisztaság).

\subsubsection{Gázkromatográfiával kapcsolt tömegspektrometria}

Lehetőség van tömegspektrometriát mint detektort alkalmazni, amennyiben egy olyan módszerrel kombináljuk, amely során valamilyen módon ionizáljuk az analizálandó anyagot. Az ionizáció hatására vizsgált anyag fragmentálódhat, amelyek köszönhetően pontosabb képet tudunk kapni a mintába elöforduló anyagokról, valamint lehetőséget ad az izotópjelzett mérések kivitelezésére. Amennyiben ezt a mérőberendezést egy olyan 
rendszerrel kombináljuk, amely nagy hatékonysággal képes szétválasztani az egyes komponenseket, akkor egy nagyon érzékeny analitikai technikához juthatunk. Ennek segítségével képesek lehetünk folyadékminták analízisére vagy izotóp jelzett mérések is kivitelezhetőek.

A keletkezett $\mathrm{CO}_{2}$ redukciós termékek forrásának vizsgálatára szén 13-as izotóppal jelzett méréseket $0,10 \mathrm{M} \mathrm{NaH}{ }^{13} \mathrm{CO}_{3}\left(98 \%{ }^{13} \mathrm{C}\right.$, Sigma-Aldrich) elektrolitban végeztük, amelyet ${ }^{12} \mathrm{CO}_{2}$ gázzal telítettünk. Először az elektrolizáló cellát $35 \mathrm{~cm}^{3}$ ioncserélt vízzel töltöttük fel, majd 30 percen keresztül ${ }^{12} \mathrm{CO}_{2}$-vel buborékoltattuk. Ezután a megfelelö mennyiségű $\mathrm{NaH}^{13} \mathrm{CO}_{3}$ adtunk az előzetesen ${ }^{12} \mathrm{CO}_{2}$-vel telített vízhez, és a cellát teljesen lezártuk. A (foto)elektrolízis előtt az elektrolitot két órán keresztül kevertettük annak érdekében, hogy beálljon az egyensúly a gázfázisban a $\mathrm{CO}_{2}$ és a folyadékfázisban a hidrogén karbonát között. Az elektrolizáló cella katódterében $35 \mathrm{~cm}^{3}$ elektrolit és $29 \mathrm{~cm}^{3}$ gáztér volt. Az elektrolízis során $100 \mu 1$ térfogatú gázmintát injektáltunk egy gázzáró fecskendővel a Shimadzu 2010 GC-MS készülékbe, amely RT $^{\circledR}$-Msieve 5A kolonnával volt felszerelve. A fütési program a következő volt: $50{ }^{\circ} \mathrm{C}-\left(10{ }^{\circ} \mathrm{C} /\right.$ perc $)-110{ }^{\circ} \mathrm{C}-$ $\left(30{ }^{\circ} \mathrm{C} /\right.$ perc) $-150{ }^{\circ} \mathrm{C}$ (3 perc), injektálási hömérséklet: $200{ }^{\circ} \mathrm{C}$, split arány: $50: 1$, nyomásszabályzó mód (50kPa). 


\section{Kísérleti eredmények és értékelésük}

\subsection{NiO és Pt/NiO kompozit fotokatód előállítása és jellemzése}

\subsubsection{NiO anodizációs szintézise}

Három különböző elektrolitot használtunk az anodizációs eljárás során a NiO rétegek előállításához. Az első kettőt a szakirodalomból adaptáltuk: [43,121].

(1. eljárás) Vizes oldat: $0,5 \quad \mathrm{M} \quad \mathrm{NH}_{4} \mathrm{~F}$-ot oldottunk $85 \mathrm{~m} / \mathrm{m} \% \quad \mathrm{H}_{3} \mathrm{PO}_{4}$-ban. $\mathrm{Az}$ anodizációs feszültséget $6 \mathrm{~V}-10 \mathrm{~V}$ között változtattuk, az anodizációs idő 10 perc volt [121].

(2. eljárás) Szerves közeg: 0,5 m/m\% KOH, $5 \mathrm{~m} / \mathrm{m} \% \mathrm{H}_{2} \mathrm{O}$, és $94,5 \mathrm{~m} / \mathrm{m} \%$ etilén-glikol. Az anodizációs feszültséget $40 \mathrm{~V}-60 \mathrm{~V}$ között változtattuk, az anodizációs idő minden esetben 1 óra volt [43].

(3. eljárás) Vegyes közeg: $0,15 \mathrm{M} \mathrm{KOH}, 0,1 \mathrm{M} \mathrm{NH}_{4} \mathrm{~F}$ koncentrációjú etilén-glikol oldat $3 \mathrm{~V} / \mathrm{V} \% \mathrm{H}_{2} \mathrm{O}$ tartalommal. A szintézis során $20-40 \mathrm{~V}$ feszültséget alkalmaztunk 1 órán keresztül.

\subsubsection{Az alkalmazott anodizációs módszerek összehasonlítása}

Az 1. eljárás során az anodizációs feszültség növelésével párhuzamosan fokozatos növekedést tapasztaltunk az állandósult áramban (18. ábra A). Ez a trend a fém egyre nagyobb mértékű oldódásához köthető [43], amely befolyásolja a pórusátmérőket a kapott elektródon [101].
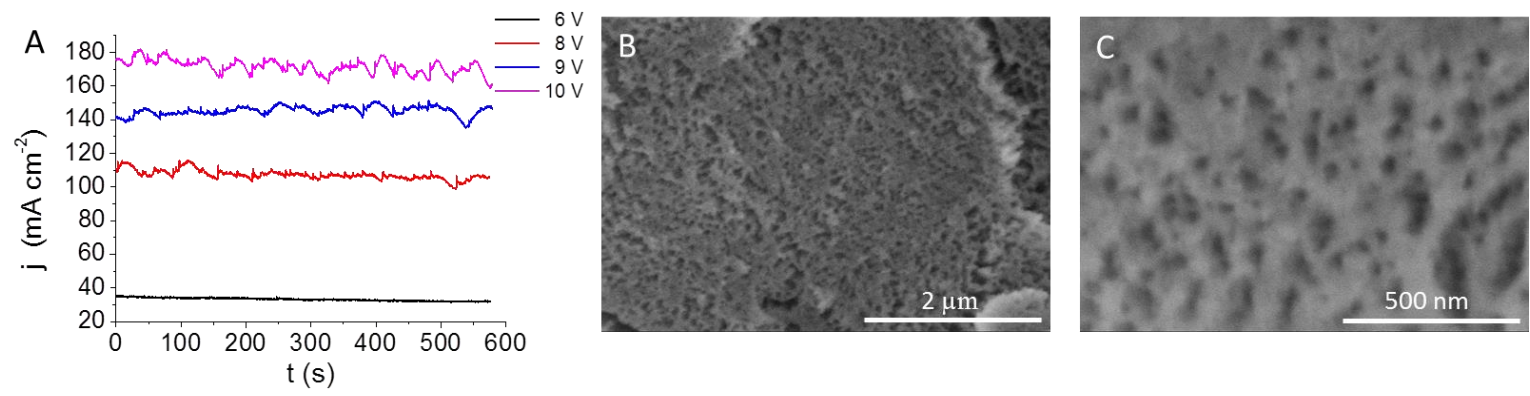

18. ábra: (A) Az alkalmazott feszültség hatása az anodizációs görbékre (1. eljárás); (B, C) SEM felvételek a $0,5 \mathrm{M} \mathrm{NH} \mathrm{N}_{4} \mathrm{~F}, 85 \% \mathrm{H}_{3} \mathrm{PO}_{4}$ oldatban anodizált mintákról (1. eljárás).

A 6 V-on anodizált minták kompakt morfológiát mutattak, nanopórusok kialakulását nagyobb feszültség alkalmazása esetén tapasztaltunk (18. Ábra B és C). Sajnos azonban, ez a módszer fluor és foszfor szennyeződéseket vitt be a szerkezetbe (19. ábra A), amely a hőkezelés hatására a felszíni rétegbe került, rontva azok fotoelektrokémiai aktivitását. Mint 
látható (19. ábra B) mind a két esetben mindössze néhány mikroamperes nagyságú fotoáramot mértünk a vizsgált potenciáltartományon.
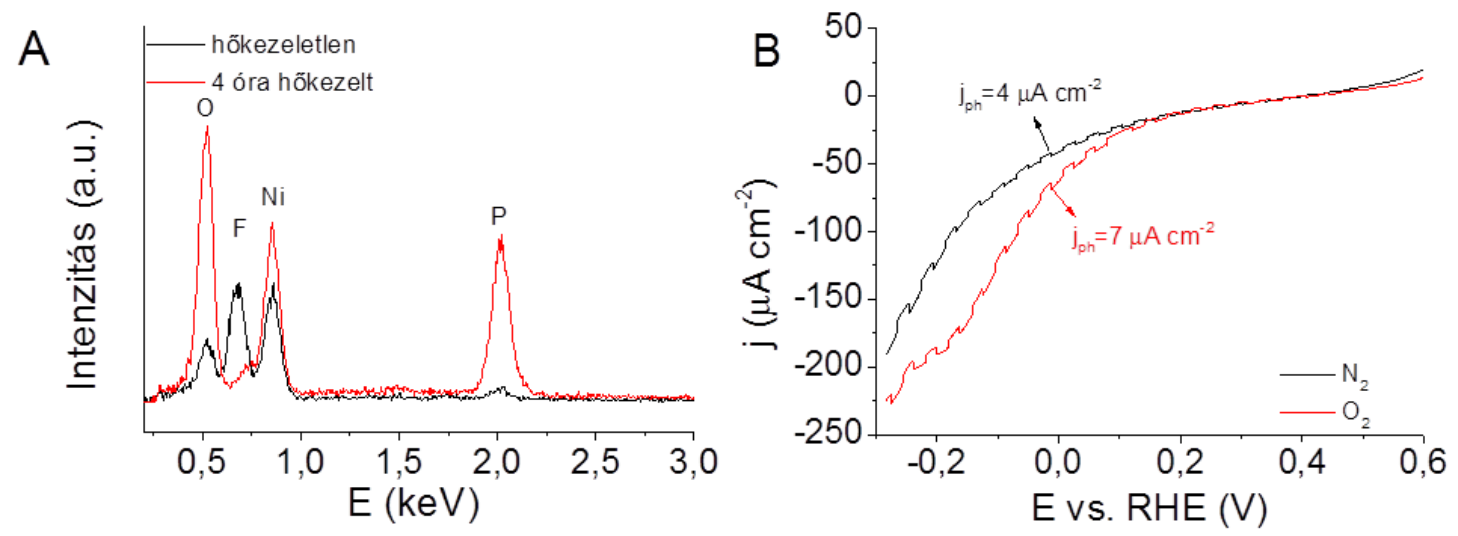

19. ábra: (A) A NiO minták EDX spektruma, (1. eljárással készült réteg), hőkezeletlen és a hökezelt $\left(\mathrm{T}=300{ }^{\circ} \mathrm{C}, 4\right.$ óra) esetben $\mathrm{U}=10 \mathrm{~V}, \mathrm{t}=10$ perc mellett; (B): NiO minta lineáris fotovoltammogramja $\left(5 \mathrm{mV} \mathrm{s}^{-1}, 0,1 \mathrm{~Hz}\right.$ fény megszakítással), 1. eljárás, $\mathrm{U}=10 \mathrm{~V}$, 10 perc szintézis idővel készült. A voltammogrammok $\mathrm{N}_{2}$-el vagy $\mathrm{O}_{2}$-el telített $0,2 \mathrm{M}$ $\mathrm{Na}_{2} \mathrm{SO}_{4}$-ban voltak mérve.

Annak érdekében, hogy elkerüljük a foszforszennyeződés bekerülését a mintába, olyan elektrolitot alkalmaztunk, amely nem tartalmaz foszfát ionokat. Ehhez egy etilén-glikol alapú oldatot használtuk, amelyben komplexáló anyagként $\mathrm{KOH}-\mathrm{t}$ oldottunk (2. eljárás). Ebben az esetben azonban a $\mathrm{NiO}$ réteg marási sebessége túl nagy volt, ami végül a teljes Ni lemez feloldódásához vezetett.

Azért, hogy mindkét hátrányt kiküszöböljük - nevezetesen a foszfát szennyeződést, valamint a túl gyors oldódást -, egy összetett elektrolitot alkalmaztunk. A szintéziskörülmények optimalizálása a következő oldatösszetételhez vezetett: etilénglikolban oldott $0,15 \mathrm{M} \mathrm{KOH}, 0,1 \mathrm{M} \mathrm{NH} \mathrm{NH}_{4} \mathrm{~F}$, valamint $3 \mathrm{~V} / \mathrm{V} \% \mathrm{H}_{2} \mathrm{O}$ (3. eljárás). A továbbiakban ezen szintézismódszer eredményeit mutatom be.

Mivel szerves oldószert használatunk a szintézis során ezért, nagyobb anodizációs feszültséget alkalmaztunk a vizes közeghez képest (a nagyobb oldatellenállás miatt). Ahogy az anodizációs feszültséget növeltük, úgy gyorsabb Ni marást figyeltünk meg. Az anodizációs görbék egy tipikus jellemzője, hogy az anodizációs áramsűrüségeknek van egy maximuma (20. ábra) [122,123]. Ezt a nagymértékü felületnövekedéshez lehet kötni, ami a pórusok kialakulása során jön létre. Amikor a két egymással versengő folyamat (oxid kialakulás és oldódás) eléri az állandósult állapotot, akkor közel állandó áramsűrűség alakul ki az anodizáció során. 


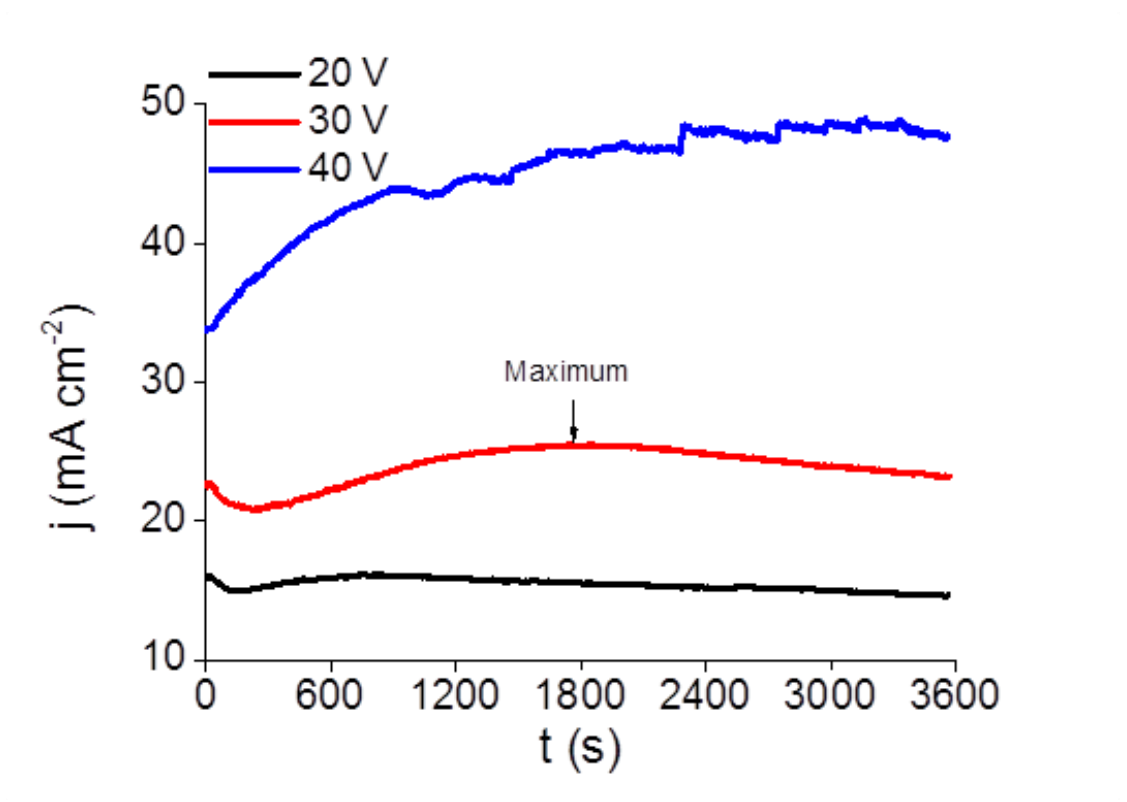

20. ábra: Az alkalmazott feszültség hatása az anodizációs görbére $0,15 \mathrm{M} \mathrm{KOH}, 0,1 \mathrm{M}$ $\mathrm{NH}_{4} \mathrm{~F}, 3 \% \mathrm{~V} / \mathrm{V} \%$ vizet tartalmazó etilén-glikol oldatban (3. eljárás).

\subsubsection{Az optimalizált anodizációs körülmények között készült NiO rétegek morfológiai} és szerkezeti jellemzése

Annak érdekében, hogy tanulmányozzuk a 3. eljárással, különböző anodizációs feszültségeknél készített minták morfológiáját, pásztázó elektron mikroszkóp képeket készítettünk a $30 \mathrm{~V}$ feszültségen anodizált mintákról (21. ábra A). A nanopórusos morfológia minden mintán megfigyelhető volt, azonban a pórusméretek különböztek a különbözö feszültség értékek esetében. Nagy nagyítás mellett szorosan összekapcsolódott nanopórusos szerkezet figyelhető meg. A pórusok méretei a 15 \pm 5 nanométeres (21. ábra B) tartományba esnek, amíg a szemcseméret nagyobb volt ( $20 \mathrm{~nm}$ TEM képek). Ezek a morfológiai jellemzők hasonlóak voltak a fluorid tartalmú elektrolit esetén tapasztaltakhoz (1. eljárás). Minden további kísérletben a minták $U=30 \mathrm{~V}$-on 1 órán keresztül alkalmazott anodizációval készültek. 

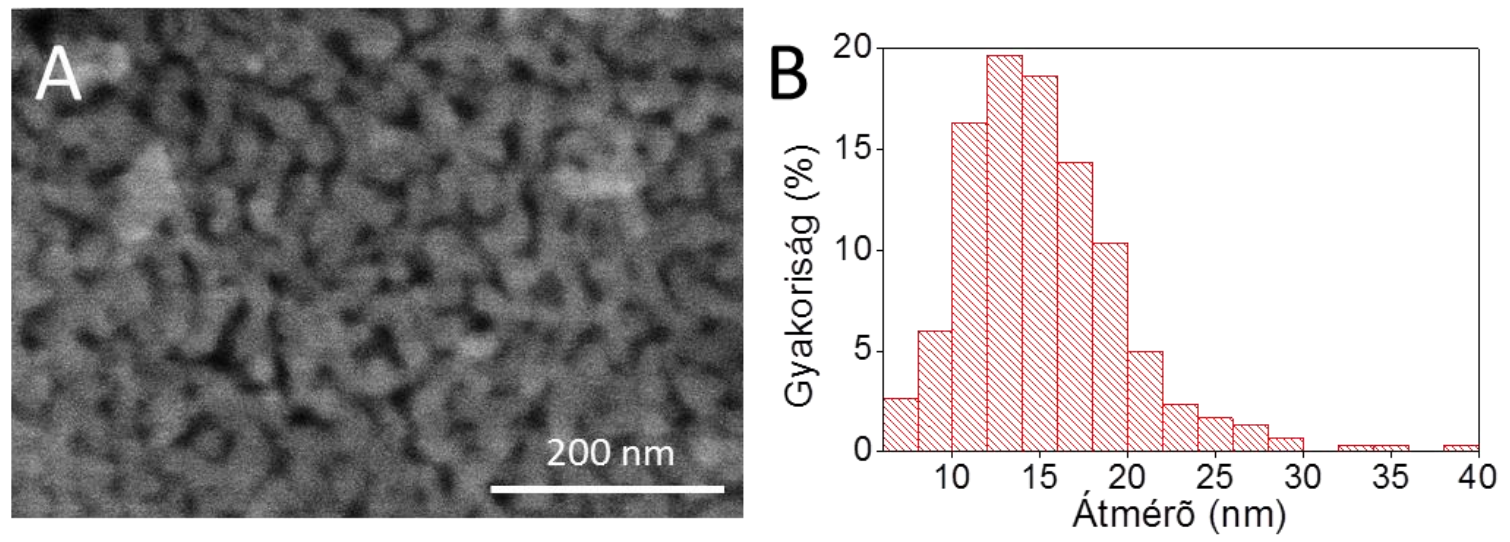

21. ábra: (A) SEM felvétel az $500{ }^{\circ} \mathrm{C}$-on 1 órán kezelt nanopórusos $\mathrm{NiO}$ anódizált mintáról, amelyet $\mathrm{U}=30 \mathrm{~V}-$ on, 1 órás anodizációval állítottunk elő. (B) Pórusméreteloszlás a NiO minta esetén.

Az elektrokémiai anodizáció általában egy amorf oxid kialakulását eredményezi, ezért gyakran egy ezt követő hőkezelési lépés szükséges. Azért, hogy megvizsgáljuk a hőkezelés $\left(300-600{ }^{\circ} \mathrm{C}\right)$ hatását a minták kristályosságára, röntgendiffraktciós méréseket végeztünk (22. ábra). A kereskedelmi forgalomban kapható NiO por diffraktogrammja szolgált referenciaként. A hőkezeletlen minta esetén NiO-hoz rendelhető reflexiók nem voltak megfigyelhetőek a diffraktogrammokon, aminek valószínüsíthetően az volt az oka, hogy a NiO amorf oxidként volt jelent. A Ni fólia éles reflexiói (csillaggal jelöltük az ábrán) jól megfigyelhetőek. $500{ }^{\circ} \mathrm{C}$-nál nagyobb hőmérsékletű hőkezelést követően a $\mathrm{NiO}$ legintenzívebb reflexiói megjelentek (JCPDS \#47-1049) a mintákon. Az átlagos kristálydomén méretet a legintenzívebb (111) diffrakcióból számoltuk ki a Bragg-féle egyenlet segítségével. Erre $\mathrm{d}=22 \mathrm{~nm}$ értéket kaptunk, ami nagyon hasonló volt a TEM képekböl meghatározottakhoz. 


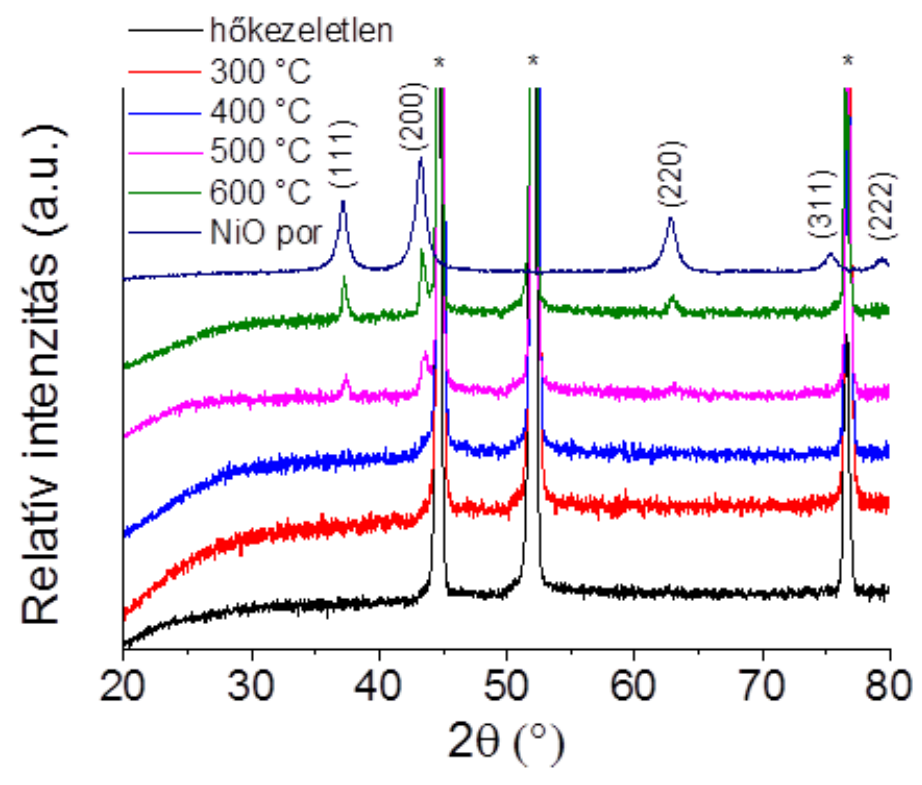

22. ábra: $X R D$ diffrakciók az anodizált $\mathrm{NiO}$ mintán $(\mathrm{U}=30 \mathrm{~V}, 1$ óra), a mintákat 1 órán keresztül hőkezeltük különböző hőmérsékleten, valamint referenciaként a $\mathrm{NiO}$ por szolgál. A láthatóság kedvéért a görbék el lettek tolva egymástól.

A $\mathrm{NiO}$ rétegek részletesebb megismerése érdekében Raman spektroszkópiás méréseket végeztünk (23. ábra). A referencia NiO pornak három Raman aktív vibrációs modusa van, amelyek megfelelnek az egy fononos LO modusnak $\left(\sim 513 \mathrm{~cm}^{-1}\right)$, két-fononos TO + LO $\left(\sim 851 \mathrm{~cm}^{-1}\right)$ és a 2LO-nak $\left(\sim 1048 \mathrm{~cm}^{-1}\right)$. Ezek az értékek jó egyezést mutatnak a szakirodalomban közöltekkel [124]. A hőkezelés hőmérsékletét növelve az LO modus intenzitásának fokozatos növekedése tapasztalható. A vibrációs modus hiányzik a hőkezeletlen minta esetén, de azonnal láthatóvá válik $300{ }^{\circ} \mathrm{C}$-os hőkezelést követően.

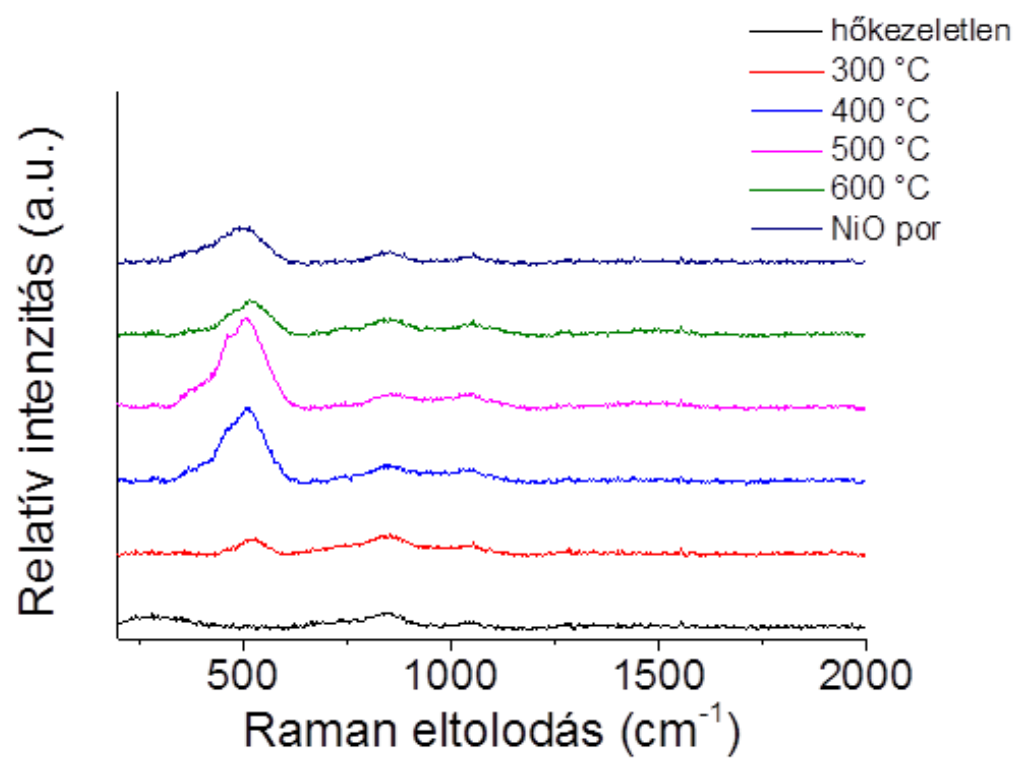

23. ábra: $\mathrm{Az}$ anodizált $\mathrm{NiO}$ mintákra $(\mathrm{U}=30 \mathrm{~V}, 1$ óra) mért Raman spektrumok különböző hőmérsékleten való hökezelést követően. Referenciaként a $\mathrm{NiO}$ port használtunk. . A láthatóság kedvéért a görbék el lettek tolva egymástól. 
Az XRD (22. ábra) és Raman (23. ábra) spektroszkópiás mérések alapján a már kristályos, $500{ }^{\circ} \mathrm{C}$-on hőkezelt mintát vizsgáltuk tovább. Az EDX mérések azt mutatták, hogy ellenben az 1. módszerrel ennél az ejárásnál 1 óra hőkezelést követően sem detektálható fluorid- vagy foszforszennyeződés a mintában (24. ábra). A mintában maradt kis mennyiségü szén szennyeződés eltávolítása érdekében a hőkezelési időt megnöveltük 4 órára.

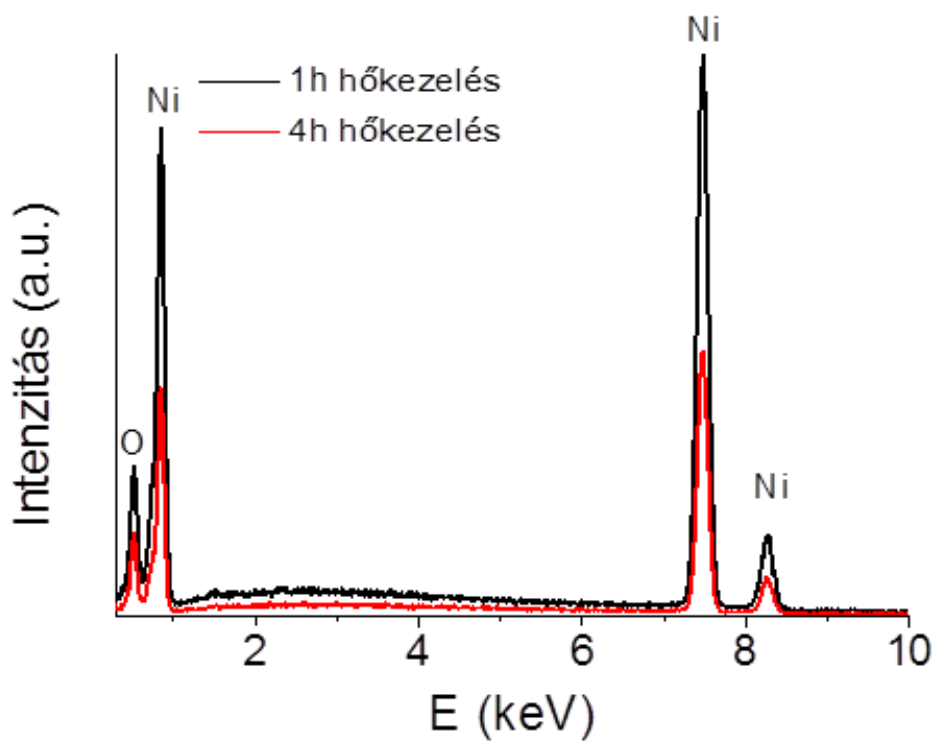

24. ábra: $\mathrm{A} \mathrm{NiO}$ minta $\mathrm{EDX}$ görbéi $(\mathrm{U}=30 \mathrm{~V}, 1$ óra). A mintákat különböző ideig hökezeltük $500{ }^{\circ} \mathrm{C}$-on.

5.1.4. A NiO rétegek elektrokémiai és fotoelektrokémiai jellemzése

A nanopórusos $\mathrm{NiO}$ rétegek elektrokémiai viselkedését ciklikus voltammetria segítségével vizsgáltuk (25. ábra). Referencia mérésként $\mathrm{NiO}$ port rögzítettünk egy üvegszén (GC) elektródra porlasztva fújással, valamint egy kompakt $\mathrm{NiO}$ réteget is vizsgáltunk, amelyet úgy állítottunk elö, hogy az anodizáció során a komplexáló anyagot $\mathrm{Na}_{2} \mathrm{SO}_{4}$-al helyettesítettük.

A NiO voltamogrammján általában két határozott oxidációs csúcsot figyelhetünk meg [125]. Az első $\mathrm{E}=+0,9 \mathrm{~V}$-nál (vs. RHE) a felszínen található hidratált $\mathrm{Ni}(\mathrm{OH})_{2}$ különböző $\mathrm{NiO}(\mathrm{OH})$ fázisokká való oxidációjához köthető (23. egyenlet) [125]. A pontos reakció azonban különböző fázisátmeneteket foglal magában, amelyeket a Bode modell ír le [126]. A második oxidációs csúcs $\mathrm{E}>1,35 \mathrm{~V}$ felett indul el, és ez a $\mathrm{NiO} \mathrm{Ni}_{2} \mathrm{O}_{3}$-dá való alakulásához rendelhető (24. egyenlet) [127]: 


$$
\begin{gathered}
\mathrm{Ni}(\mathrm{OH})_{2} \rightarrow \mathrm{NiO}(\mathrm{OH})+\mathrm{H}^{+}+e^{-} \\
2 \mathrm{NiO}+\mathrm{H}_{2} \mathrm{O} \rightarrow \mathrm{Ni}_{2} \mathrm{O}_{3}+2 \mathrm{H}^{+}+2 e^{-}
\end{gathered}
$$

A mi esetünkben egy kiszélesedett oxidációs csúcs jelenik meg, körülbelül $\mathrm{E}=1,0 \mathrm{~V}$ potenciálon (25. ábra $\mathrm{A})$. Ez a $\mathrm{Ni}(\mathrm{OH})_{2}$ különböző $\mathrm{NiO}(\mathrm{OH})$ fázisokká való átalakulásához köthető. A meghatározott töltéskapacitásokból azt a következtést tudtuk levonni, hogy a nanopórusos minták felülete nagyobb mind a felfújt $\mathrm{NiO}$ nanopor réteghez (3-szoros növekedés), mind pedig a kompakt $\mathrm{NiO}$ réteghez viszonyítva (27-szeres növekedés).
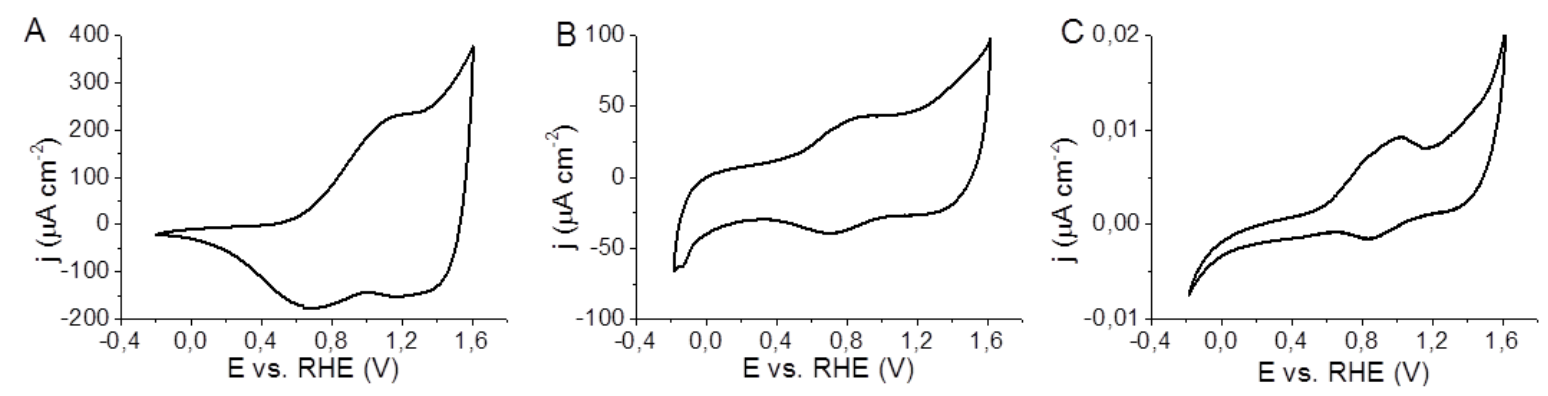

25. ábra: Ciklikus voltamogrammok - $\mathrm{N}_{2}$-vel telített $0,2 \mathrm{M} \mathrm{Na}_{2} \mathrm{SO}_{4}$ oldatban $50 \mathrm{mV} \mathrm{s}^{-1}$ pásztázási sebesség mellett. (A) Nanopórusos $\mathrm{NiO}$ mintánál (B) $\mathrm{NiO}$ por szénüveg elektródon; (C) kompakt $\mathrm{NiO}$ réteg.

Lineáris pásztázó fotovoltammetriás mérésekkel vizsgáltuk a rétegek fotoelektrokémiai tulajdonságait. A megvilágítás hatására katódos áramokat figyeltünk meg minden mintán, ami azt jelzi, hogy a készített minták p-típusú félvezetők. A mérések során az oldatban nem volt áldozati ágens (elektron akceptor), így a megvilágításra adott válasz a víz fotoelektrokémiai redukciójához köthető.

A hőkezelt anodizált mintához képest mind a NiO nanopornak, mind a kompakt $\mathrm{NiO}$ rétegeknek lényegesen kisebb volt a fotoaktivitása (26. ábra). A pormintákon valószínüsíthetően előtérbe került a töltéshordozók rekombinációja a nanorészecskék felszínén, ami nagymértékben meghatározza az anyag fotoválaszát. A kompakt réteg esetén más történik. Bár a részecskék közötti határfelület hiányzik, a fotogenerált töltéshordozókat nem lehet kinyerni az oxid tömbi fázisából (a kis elektromos vezetésnek köszönhetően). Ebből azt a következtetést lehet levonni, hogy az anodizált minták esetén a jobb fotoelektrokémiai aktivitást azért tapasztaljuk, mert egy szorosan összekapcsolódott szerkezet alakul ki, amelyben gyorsabb a töltéshordozók transzportja, ráadásul csak rövidebb utat kell megtenniük, hogy az oldatfázissal találkozzanak. 
Az anyag fényelnyelö-képességét befolyásoló egyik fontos paraméter a kristályosság. Az anodizált mintákat két különböző hőmérsékleten hőkezeltük. A $300{ }^{\circ} \mathrm{C}$-on hőkezelt nem kristályos minta sokkal kisebb fotoáramokat produkált, mint a $500{ }^{\circ} \mathrm{C}$-on hökezelt minták $\left(\mathrm{J}_{\text {foto }}=-80 \mu \mathrm{A} \mathrm{cm} \mathrm{cm}^{-2} \mathrm{E}=-0,1 \mathrm{~V}\right.$-on $)$.
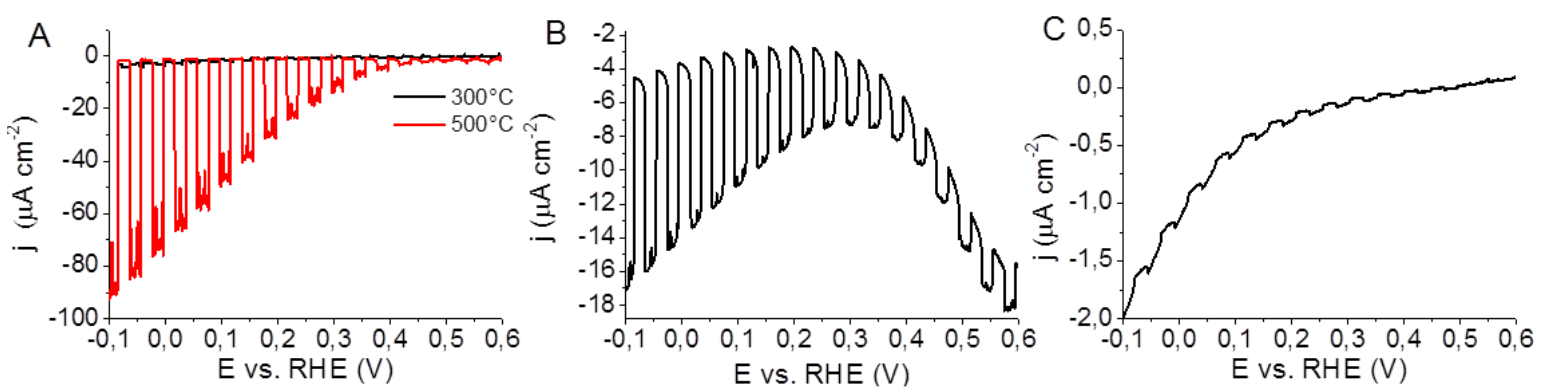

26. ábra: Lineáris pásztázó fotovoltammogramok $0,2 \quad \mathrm{M} \mathrm{Na} \mathrm{Na}_{2} \mathrm{SO}_{4}$-ban $2 \mathrm{mV} \mathrm{s}^{-1}$ pásztázási sebesség mellett, a fényszaggatás frekvenciája $0,1 \mathrm{~Hz}$ volt. (A) Nanopórusos $\mathrm{NiO}$ mintánál (300 és $500{ }^{\circ} \mathrm{C}$-on hökezeltek) (B) $\mathrm{NiO}$ por szénüveg elektródon; (C) kompakt $\mathrm{NiO}$ réteg

\subsection{5. $\mathrm{Pt} / \mathrm{NiO}$ morfológiai és elektrokémiai jellemzése}

A Pt/NiO elektródok morfológiáját vizsgálandó SEM és TEM képeket készítettünk. A $\mathrm{Pt} / \mathrm{NiO}$ elektród SEM képe (7,2 nm-es átlagos átmérővel rendelkező $\mathrm{Pt}$ esetén) összehasonlítva a tiszta NiO-val a 27. ábrán látható. Még nagy nagyítások mellett is a 7,2 nm-es Pt nanorészecskék túl kicsik ahhoz, hogy közvetlenül megfigyeljük ezeket a felszínen, azonban volt néhány különbség, amely jelzi a Pt jelenlétét a NiO réteg felszínén. Először is a felszín simábbnak néz ki a Pt felcseppentése után, mint előtte. Mi több, a felcseppentés hatására a pórusstruktúra is megváltozott: a pórusok mérete lecsökkent, néhány még el is tömődött. Ez azt jelzi, hogy nagy mennyiségü Pt nanorészecske van a pórusokban a $\mathrm{NiO}$ réteg tetején.
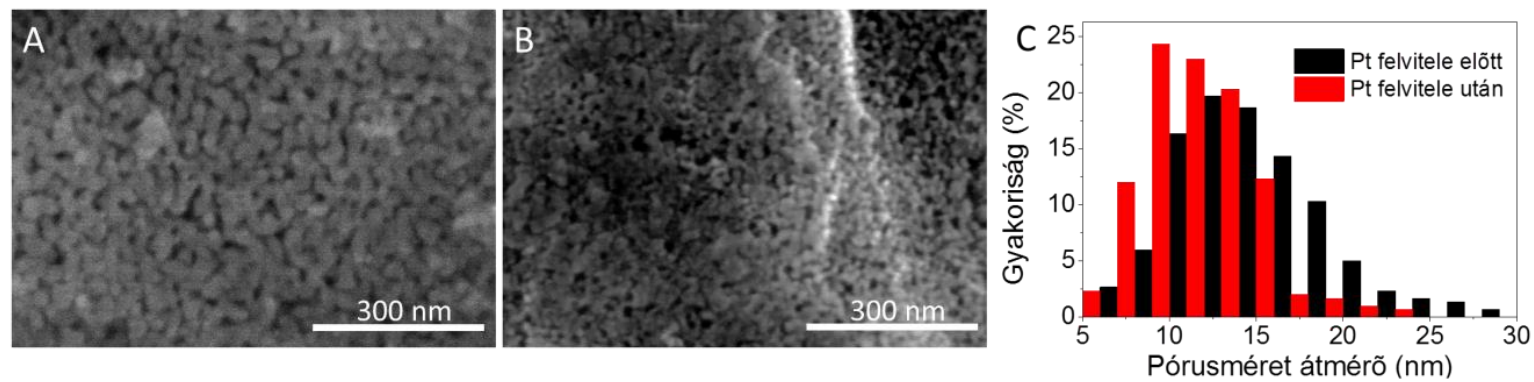

27. ábra: (A) anodizált $\mathrm{NiO}$ film rétegröl, (B) a Pt/NiO kompozitról $(7,2 \mathrm{~nm} \mathrm{Pt})$ készített SEM felvételek és $(\mathrm{C})$ pórusméret eloszlás a Pt felvitele elött és után.

A TEM vizsgálatokhoz a NiO-t eltávolítottuk az elektród felszínéről. A képeken mikropórusos struktúrát tudtuk megfigyelni rajta. Az összekapcsolódott darabok átlagos átmérője $20 \mathrm{~nm}$ körül volt. Ez az érték megegyezik az XRD és SEM mérések 
eredményeivel. A 7,2 nm-es Pt nanorészecskéket tartalmazó Pt/NiO esetében az egyedi Pt nanorészecskéket is meg lehetett figyelni a képeken (28. ábra).

Az elektrondiffraktometriás mérés segítségével beazonosítani lehetett a $\mathrm{NiO}(111), \mathrm{Ni}$ (200), NiO (200), NiO (220), NiO (311) és a NiO (222) kristálysíkjait, valamint a $\mathrm{NiO}$ felületen a középpontos köbös (fkk) nikkel(II)oxidot. A Pt-val dekorált NiO esetén megjelenik a Pt (111), Pt (200) és Pt (311), valamint a felületen középpontos kockás (fkk) platina. A Pt és a NiO közötti kölcsönhatás jobb megfigyelhetősége érdekében a $\mathrm{NiO}$ felszínére megnövelt mennyiségü Pt vittünk fel, amely mintáról nagyfelbontású TEM képet készítettünk. A TEM képek legfontosabb üzenete az, hogy a szorosan összekapcsolódott pórusos NiO-on meg lehet figyelni a Pt nanorészecskét (28. ábra A). Valamint a képeken egymás mellett megfigyelhetőek a Pt (111) valamint a NiO (111) rácssíkjai (28. ábra $\mathrm{B})$.
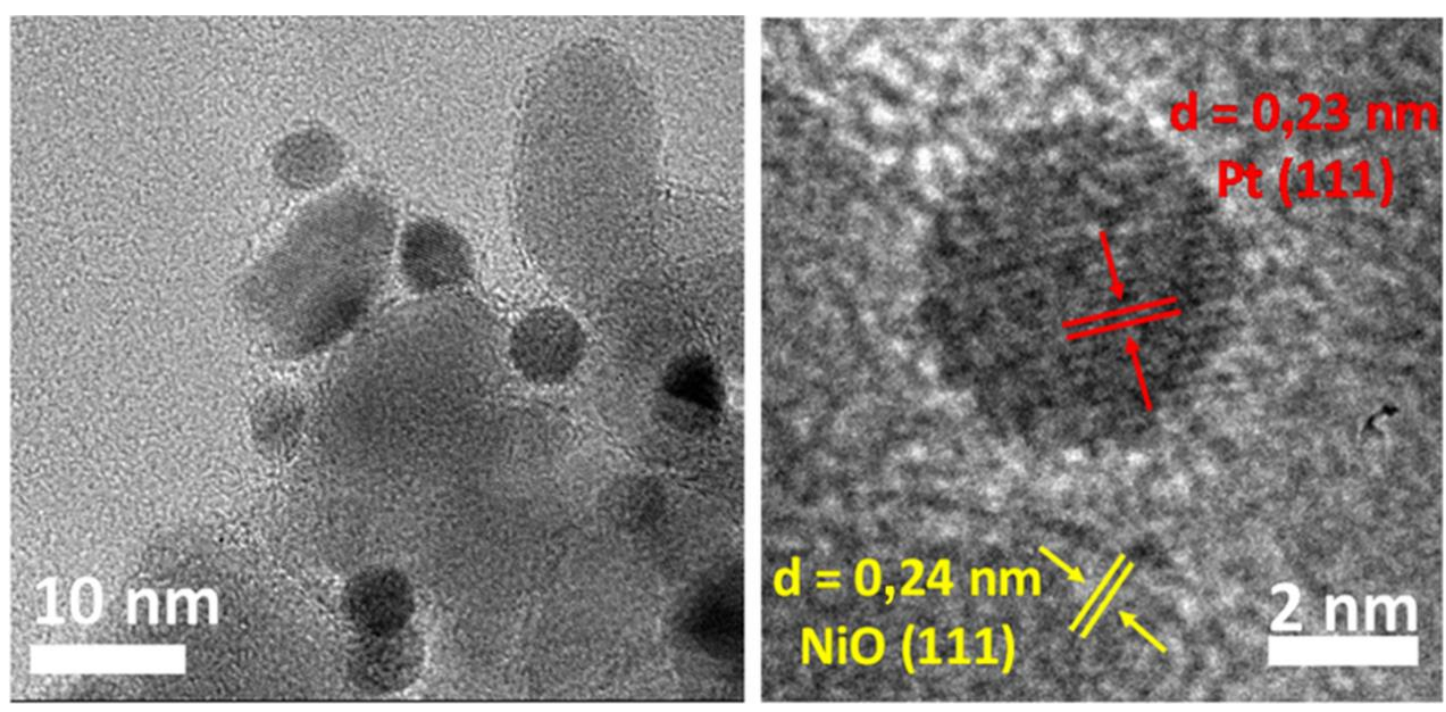

28. ábra: Nagyfelbontású TEM képek a 7,2 nm-es Pt-ról a nanopórusos NiO felszínén.

A NiO elektródon és a felszínre felcseppentett Pt nanorészecskéken röntgen fotoelektron spektroszkópiás (XPS) méréseket végeztünk. A NiO alapú anyagok komplex felületkémiai tulajdonságokkal rendelkeznek, köszönhetően a nem sztöchiometrikus összetételnek és a hidratációnak [128]. A különböző Ni-oxid/hidroxid fajták kvantitatív jellemzése az XP spektrumon nehéz, mivel csak nagyon tiszta referenciaanyagok használata mellett lehetséges [128-130]. Ezért mi csakkvalitatívan kívántuk jellemezni a felszíni tulajdonságokat.

A 29. ábrán a Ni 3p (A), Ni (2p) (B) és az O 1s (C) régiókat mutatom be a 8,6 nm átlag átmérővel rendelkező Pt-val dekorált minta esetén. Mivel nagy átlapolódás van a Ni 3p és a Pt 4f jelek között, ezért a dekonvolúciót a $\mathrm{Ni} 3 \mathrm{p}$ sávokon nem végeztük el. Az 
aszimmetrikus Pt 4f $\mathrm{f}_{7 / 2}$ komponens $(71,2 \mathrm{eV})$ helyzetéböl és a $\mathrm{Pt} 4 \mathrm{~d}_{5 / 2}$ pozíciójából (29. ábra) a nulla vegyértékü (fémes) Pt jelenlétét minden esetben meg tudtuk erösíteni (30. ábra) $[131,132]$.
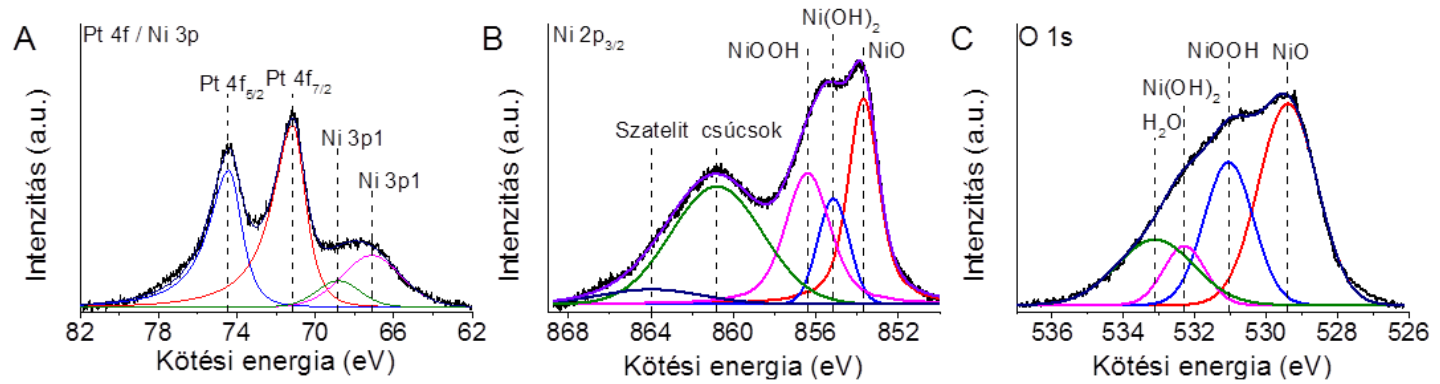

29. ábra: A 8,6 nm-es Pt nanorészecskével dekorált $\mathrm{NiO}$ minta (A) Pt 4f/Ni $3 p$ XP spektruma, (B) Ni 2p $p_{3 / 2}$ XP spektruma, és a (C) O 1s XP spektruma. A felbontott görbéket csak illusztrációként adjuk meg annak érdekében, hogy a változások nyomon követhetőek legyenek. A felbontások nem kvantitatívak.

Kis mennyiségű platina-oxidot $(\mathrm{PtO})$ a $\mathrm{NiO}$ felszínen csak a legkisebb átmérőjű $\mathrm{Pt}$ nanorészecske esetén tudtunk kimutatni (30. ábra). A fö $\mathrm{Ni} 2 \mathrm{p}_{3 / 2}$-on megfigyelhető csúcsokat három összetevővel modelleztük: (i) $\mathrm{NiO}(853,7 \mathrm{eV})$, (ii) $\mathrm{Ni}(\mathrm{OH})_{2}(855,2 \mathrm{eV})$ és $\mathrm{NiOOH}(856,4 \mathrm{eV})$, amelyek jó egyezést mutattak a szakirodalomban közölt eredményekkel [128]. A NiOOH hozzáadása a modellhez az anyag kémiai természetéből fakadt, mivel az elektrokémiai úton növesztett $\mathrm{NiO}$ esetében is kialakul ez a fázis $[43,133]$. A szakirodalomi adatok alapján az $\mathrm{O}$ 1s régióban is az előzőekben felsorolt anyagokat tudtuk azonosítani [128].

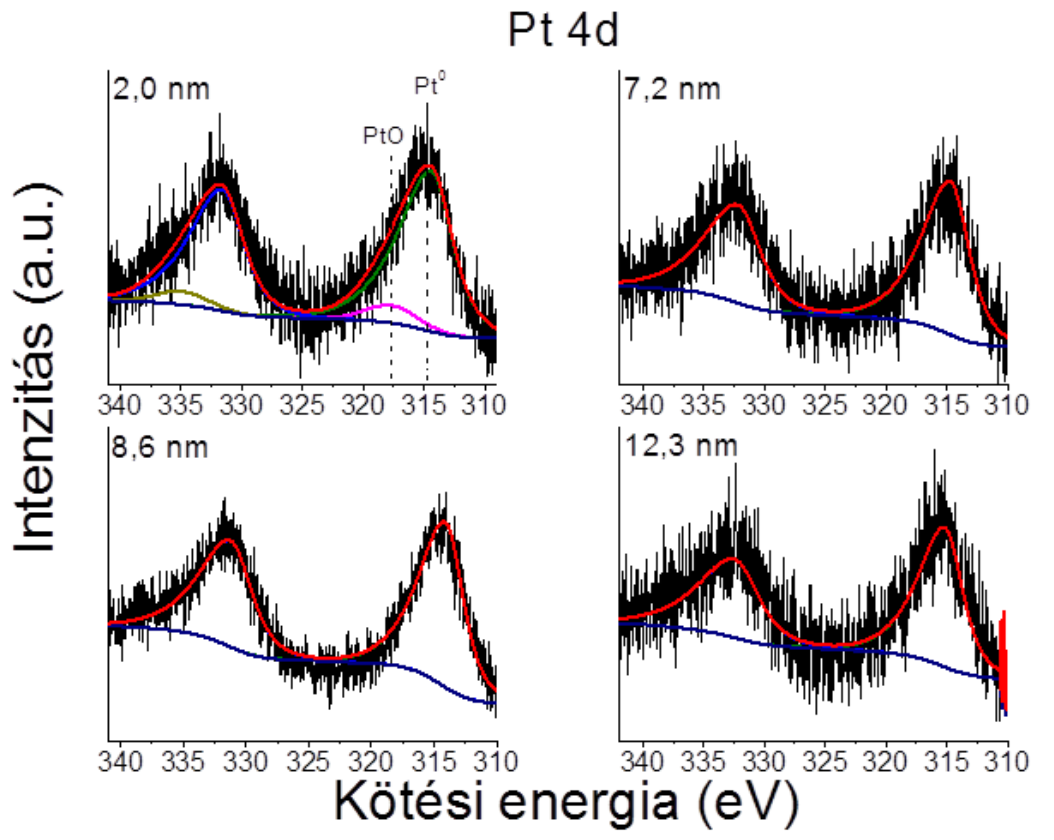

30. ábra: $\mathrm{Pt} / \mathrm{NiO}$ nanokompozitok $\mathrm{Pt} 4 \mathrm{~d} \mathrm{XP}$ spektruma különböző méretű $\mathrm{Pt}$ nanorészecskékkel $\left(2 \mu \mathrm{g} \mathrm{cm}^{-2}\right.$ felületi mennyiség). 


\subsection{6. $\mathrm{Pt} / \mathrm{NiO}$ (foto)elektrokémiai vizsgálata}

$\mathrm{Pt} / \mathrm{NiO}$ nanokompozitok sötét elektrokémiai viselkedésének vizsgálatára ciklikus voltammetriát alkalmaztunk (31. ábra A). Két fő trendet figyeltünk meg hozzáadott Pt hatására: (i) sötét áram növekedés tapasztalható az $\mathrm{E}=-0,2 \mathrm{~V}-0,2 \mathrm{~V}$ potenciáltartományon (ez a felületen rögzített $\mathrm{Pt}$ nanorészecskék elektrokémiai viselkedésének tulajdonítható), valamint (ii) a rétegek töltéskapacitása megnövekedett (az egész potenciáltartományon nagyobb áramok mérhetők).

A lineáris fotovoltammetriás mérések során a $\mathrm{Pt}$ mentes $\mathrm{NiO}$ esetén a sötét áram elhanyagolható volt a vizsgált potenciáltartományon. Amikor a $\mathrm{NiO}$ elektród felszíne Ptval volt dekorálva, a sötétáram fokozatos növekedését figyeltünk meg az $\mathrm{E}=-0,2 \mathrm{~V}-+0,2$ $\mathrm{V}$ tartományon. A fotoáram megindulása (onset-potenciál) $\mathrm{E}=+0,4 \mathrm{~V}$-nál figyelhető meg, függetlenül a Pt nanorészecskék méretétől. Ez a megfigyelés azt jelzi, hogy a nanorészecskék mérete elsősorban a víz megvilágítás nélküli elektrokémiai redukciójának kinetikáját befolyásolja.
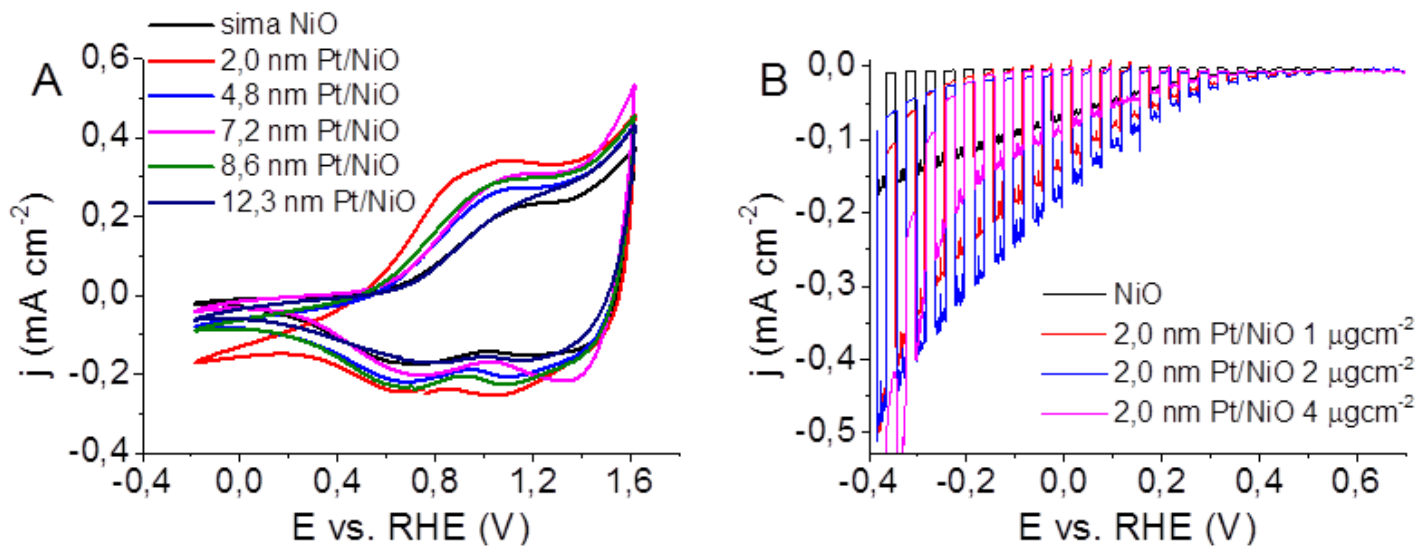

31. ábra: (A) $\mathrm{A} \mathrm{NiO}$ és a $\mathrm{Pt} / \mathrm{NiO}$ kompozit ciklikus voltammogramja $2 \mu \mathrm{g} \mathrm{cm}{ }^{-2} \mathrm{Pt}$ koncentráció esetén,50 $\mathrm{mV} \mathrm{s}^{-1}$ pásztázási sebesség mellett; (B) $2 \mathrm{~nm}$-es részecskével dekorált $\mathrm{Pt} / \mathrm{NiO}$ kompozit lineáris fotovoltammogramja különböző felületre felvitt mennyiség esetén, $\mathrm{N}_{2}$-vel telített $0,2 \mathrm{M}$-os $\mathrm{Na}_{2} \mathrm{SO}_{4}$-ban, $2 \mathrm{mV} \mathrm{s}^{-1}$ pásztázási sebesség, és 0,1 $\mathrm{Hz}$ fényszaggatás frekvencia mellett.

Pozitívabb potenciáltartományon $(\mathrm{E}>0,6 \mathrm{~V})$ nagyobb elektrokémiai aktivitás volt megfigyelhető a Pt-val dekorált $\mathrm{NiO}$ esetén, mint a sima NiO-nál. A NiO elektrokémiai átalakulása átfed a platináéval ezen a potenciáltartományon, a megnövekedett elektroaktivitás a Pt redox csúcsához köthető $[134,135]$. Az elektrokémiai aktvitás a Pt méretével fordítottan változott: az összes tanulmányozott minta közül a 2,0 nm-es $\mathrm{Pt}$ nanorészecskékkel dekorált mintáknak volt a legnagyobb elektrokémiai aktivitása. Ez az adat alapjául szolgált a későbbiekben alkalmazott a fotoelektrokémiai aktivitások 
normálásához, amely megmutatta, hogy a segédkatalizátor tényleges felszíne kulcsfontosságú az összteljesítmény vonatkozásában.

A fotovoltammetriás görbéken majdnem minden esetben (kivéve a legnagyobb $\mathrm{Pt}$ nanorészecskénél) nagyobb fotoáramokat mértünk a Pt-val dekorált NiO esetén, mint a sima NiO-nál (31. ábra B). Ezt a jelenséget a nanokompozitban végbemenő jobb elektronlyuk szeparációnak lehet tulajdonítani, azaz a fotogenerált elektronok élettartama lényegesen hosszabb, miután átléptek a Pt katalizátorra [127]. Azáltal, hogy növeltük a Pt mennyiséget a $\mathrm{NiO}$ felszínén, a fotoáram növekedését tapasztaltuk egy optimális mértékig. A maximum után további Pt felvitel esetén csökkent a fotoáram nagysága az optikai árnyékolás miatt (32. ábra A). A legnagyobb Pt méretnél az árnyékolás effektus még kisebb felvitt mennyiség esetén is jelentős volt, ami negatív irányba befolyásolta a mérhető fotoáramokat.

A Pt nanorészecskék optimális mennyiségének és méretének meghatározásához a felszínen, a sima NiO-nál mért fotoáramokat felhasználtuk minden Pt-val dekorált minta esetén a normáláshoz. A különböző minták esetén a legnagyobb mértékü növekedést akkor értük el, amikor 2,0 és 4,8 nm-es Pt nanorészecskékkel dekoráltuk a NiO rétegeket (32. ábra B).
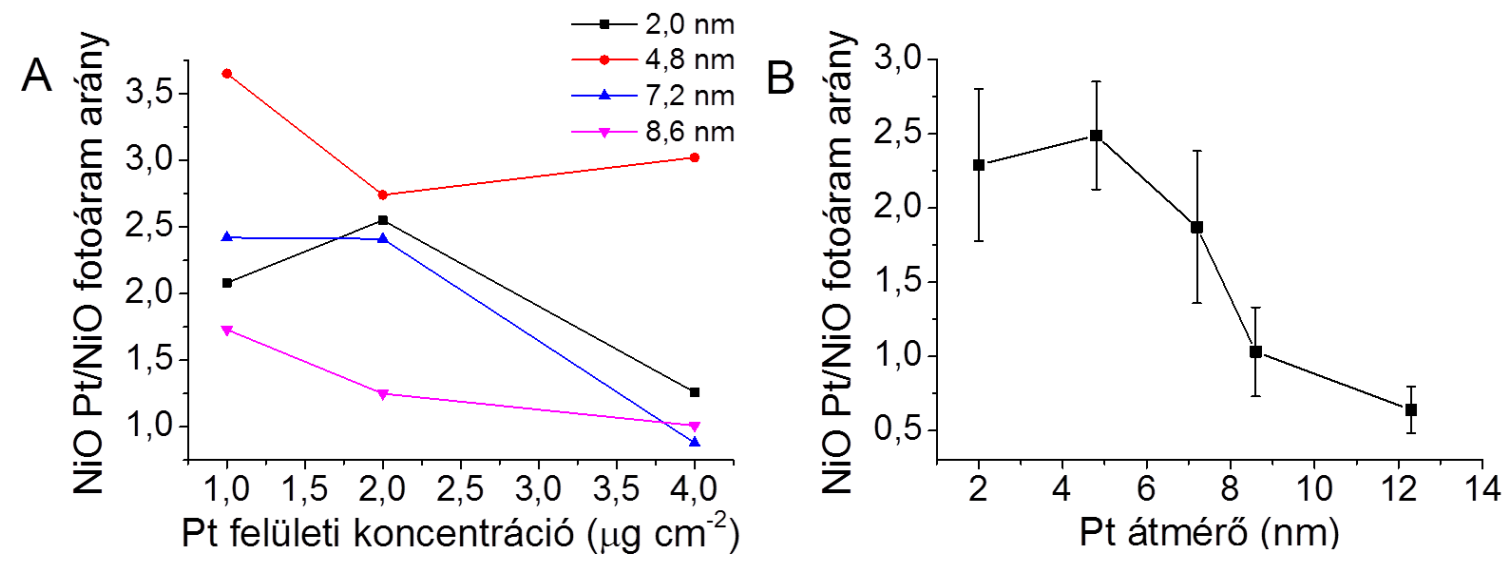

32. ábra: (A) A Pt méret és koncentráció hatása a $\mathrm{NiO}$ és a $\mathrm{Pt} / \mathrm{NiO}$ esetében mért fotoáram aránya, amelyet $-0,2 \mathrm{~V}$-on határoztunk meg. A vonalak csak a szem vezetésének érdekében vannak összekötve, (B) Nanorészecske méretének hatása a fotoáram növekedésre $\left(2 \mathrm{mg} \mathrm{cm} \mathrm{cm}^{-2}\right.$ felületi koncentráció esetén). Az adatok szórása három párhuzamos mérés eredménye, minden egyes Pt átmérő esetén. A pontok összekötése csak illusztráció.

A fotoáram növekedésnek különböző okai lehetnek. Mivel azonos felvitt Pt mennyiség mellett a Pt nanorészecskék méretei más és más felületet eredményeznek, ezért ez egy lehetséges oka megnövekedett fotoáramnak. Azért, hogy kizárhassuk ezt a faktort a többi 
ok közül, valamint más lehetőségeket felfedezhessünk, a mért fotoáram értékeken a Pt nanorészecskék felületét figyelembe vevő normálást hajtottunk végre.

A ciklikus voltamogrammokom $+0,8$ V-nál tapasztalt extra redoxi csúcs a Pt-val dekorált minták esetében a Pt nanorészecskék oxidációjához rendelhető. A normálás során első lépésben kivontuk a NiO töltéskapacitását a Pt-val dekorált mintákéból. Ezt követően a fotoáram-növekményt normáltuk az előzőekből számolt Pt-felülettel. Amikor csak a Pt felületére normálunk, akkor a fotoáram-növekmény a 4,8 nm-es és 7,2 nm-es $\mathrm{Pt}$ nanorészecskék esetén volt a legnagyobb.

Ez a megfigyelés igencsak érdekes, mivel nagyobb heterogén/elektrokatalitikus aktivitást általában a kisebb nanorészecskék esetén kaptak (legtöbbször a nagyobb számú aktív centrum miatt) a szakirodalomban [104,134,136-139]. Azonban a mi esetünkben figyelembe kell venni a kölcsönhatását a $\mathrm{NiO}$ és Pt között. A $\mathrm{NiO}$ minta átlagos pórusmérete $15 \pm 5 \mathrm{~nm}$ volt, a nagyméretü Pt részecskék egyszerüen nem képesek behatolni a nanopórusos $\mathrm{NiO}$ mélyebb régióiba, ezért inkább a tetején maradnak. Az ilyen szerkezet nyilvánvalóan nem kedvező, amennyiben figyelembe vesszük a kismértékü érintkezési felületet a NiO és Pt között, valamint a lehetséges árnyékolási effektust. Másrészről, a legkisebb (2 nm-es) Pt részekék valószínüleg az anodizált $\mathrm{NiO}$ pórusos réteg alsó régióiba hatolnak. Mivel a fény behatolása az alsóbb rétegekbe korlátozott, a segédkatalizátor hatását ezen rétegekben nem lehet teljesen kihasználni. Az átmeneti méreteknél (4,8 nm és 7,2 nm) a Pt nanorészecskék részlegesen tudnak behatolni a NiO-ba, ami a Pt/NiO nanoszerkezetnek elönye.

Ezt a felvetést fél-kvantitatívan alátámasztottuk XPS mérésekből származó adatokkal is, amikor a Pt nanorészecskék felszíni koncentrációját becsültük meg ezen mérési eredményekből. Azt találtuk, hogy a kis méretü Pt nanorészecskék nagy fajlagos felülete nem tükröződött a felszíni $\mathrm{Pt} / \mathrm{Ni}$ arányon, ezért valószínűsíthetően a Pt nanorészecskék mélyen behatoltak a $\mathrm{NiO}$ rétegbe (ahol „láthatatlanok” a XPS számára).

Elektrokémiai impedancia spektroszkópiás mérésekkel jellemeztük a Pt-val dekorált $\mathrm{NiO}$ elektródok elektromos tulajdonságait. A Nyquist-görbék a 33. ábrán láthatók. Megfigyelhető, hogy minden Pt tartalmú mintának kisebb a töltésátviteli ellenállása (a végpontok csökkenése a félkörökben) összehasonlítva a $\mathrm{NiO}$ elektródéval. A legkisebb töltésátviteli ellenállást a legkisebb Pt méretnél értük el, de összegségében minden Pt-val dekorált minta esetében sokkal kisebb volt ezen érték, mint a tiszta NiO-nak. Ez a trend azt sugallja, hogy a fotoáram növekedés a jobb töltésátvitellel magyarázható az elektród/elektrolit határfelületen. 


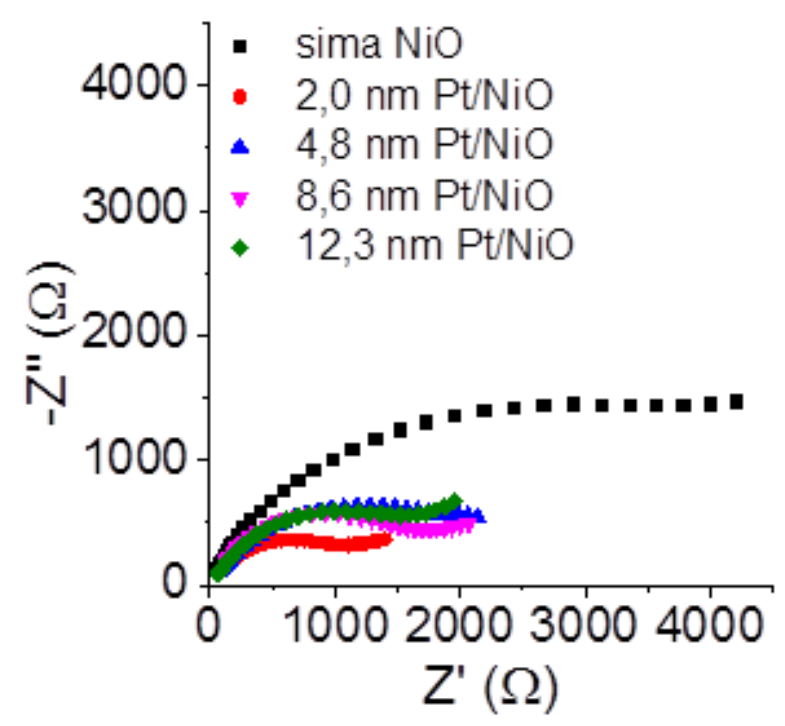

33. ábra: a Nyquist görbék a NiO-ra és a különböző Pt-val dekorált NiO mintákra, $\mathrm{E}=0,6 \mathrm{~V}$ vs. RHE, a $10 \mathrm{~Hz}-0,1 \mathrm{MHz}$ frekvencia tartományban. A méréseket $1,0 \mathrm{M}$ $\mathrm{Na}_{2} \mathrm{SO}_{4}$ oldatban végeztük.

A szakirodalomban különböző helyettesítő kapcsolásokat javasolnak az anodizációval előállított nanoszerkezetű fém-oxidok elektromos tulajdonságainak leírására. Általános vélekedés az, hogy szét kell választani a kompakt réteg alját (fém) és a pórusos rétegeket (fém-oxid) [140]. Ennek megfelelően a helyettesítési kapcsolásnak az alsó záró réteget és a felső pórusos réteget, valamint az elektrolitot tekintettük. A felszíni egyenetlenségeket úgy vettük figyelembe, hogy kicseréltük a kapacitív elemet egy konstans fázisú elemre. (34. ábra $\mathrm{A})$. $\mathrm{Az}$ alsó kompakt réteget $(\mathrm{CL})$ egy réteg ellenállással $\left(\mathrm{R}_{\mathrm{CL}}\right)$ valamint egy kapacitással $\left(\mathrm{Q}_{\mathrm{CL}}\right)$ írtuk le. A felső porózus réteget $(\mathrm{PL})$ hasonlóan egy réteg ellenállással $\left(\mathrm{R}_{\mathrm{PL}}\right)$ és egy kapacitással írtunk le $\left(\mathrm{Q}_{\mathrm{PL}}\right)$, egy Warburg taggal, kiegészítve ami a pórusos rétegen belüli ion diffúziót veszi figyelembe.
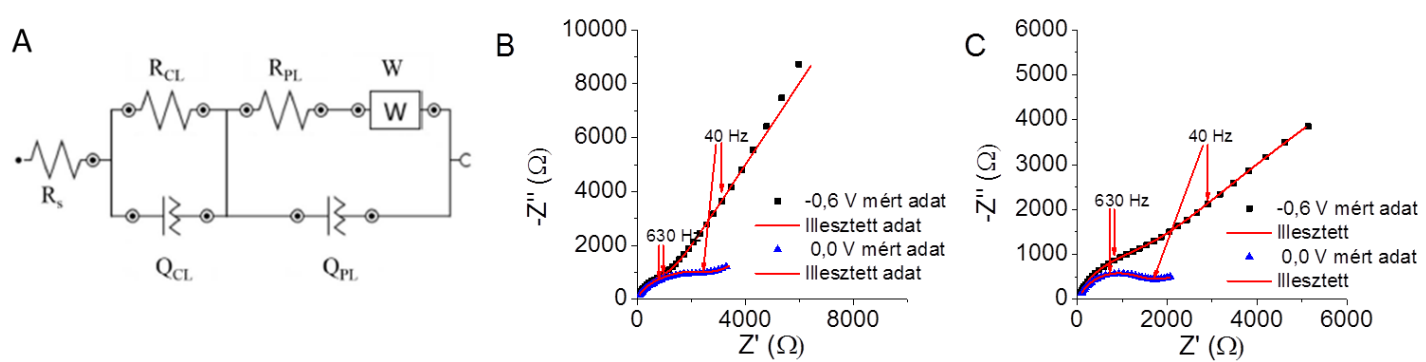

34. ábra: (A) Az alkalmazott helyettesítő kapcsolás a NiO és a Pt-val dekorált NiO mintákra, (B) Nyquist görbék a NiO-ra mintára: mérések és az illesztések az A ábrán látható helyettesítő kapcsolást felhasználva. (C) Nyquist görbék a 8,6 nm-es Pt-val dekorált $\mathrm{NiO}$ mintára: mérések és az illesztések az (A) ábrán látható helyettesítő kapcsolást felhasználva. A méréseket $\mathrm{E}=0 \mathrm{~V}$ és $\mathrm{E}=0,6 \mathrm{~V}$ potenciálon $10 \mathrm{~Hz}-0,1 \mathrm{MHz}$ tartományon $1,0 \mathrm{M} \mathrm{Na}_{2} \mathrm{SO}_{4}$ oldatban végeztük. 
Azért, hogy tovább tanulmányozzuk a fotoáram növekmény eredetét, a minták IPCE spektrumát is rögzítettük. A 35. ábra mutatja a mért IPCE spektrumokat a platinát nem tartalmazó és a 2 nm-es Pt-val dekorált NiO elektród esetén. A tiltottsáv-szélessége a fotoaktív spektrum levágási szakaszára illesztett egyeneséből került meghatározásra úgy, hogy az egyenest extrapoláltunk az $\mathrm{x}$ tengelyre. A tiltottsáv-szélessége hasonló volt mindegyik minta esetében $\left(\mathrm{E}_{\mathrm{BG}}=3,55 \mathrm{eV}\right)$ ami jó egyezést mutat a szakirodalomban található értékekkel [127]. Kijelenthetjük, hogy a NiO Pt-val való dekorációja nem változtatja meg az oxid tiltottsáv-szélességét. Továbbá megerősíti az előző állításunkat, miszerint a jobb fotoelektrokémiai aktivitás a Pt-val dekorált minták esetén a jobb töltésszeparációnak tudható be, és nem a jobb fényelnyelési tulajdonságoknak.

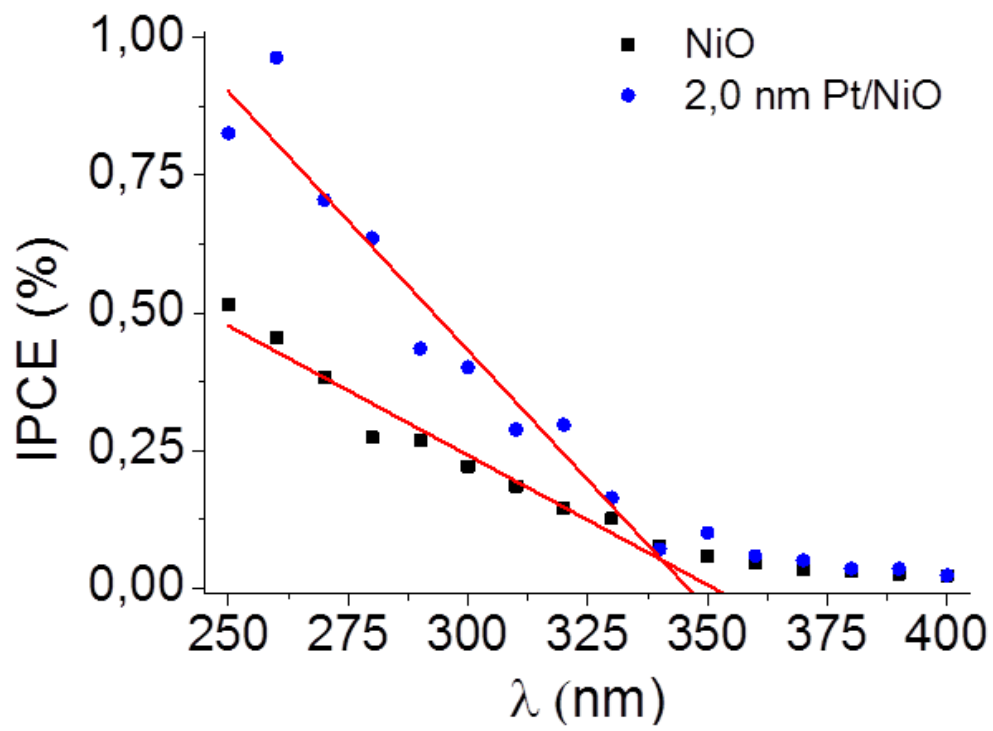

35. ábra: IPCE spektrumok a NiO-ra és a 2,0 nm-es Pt-val dekorált $\mathrm{NiO} 0,2 \mathrm{M} \mathrm{Na}_{2} \mathrm{SO}_{4}$ elektrolitban $\mathrm{E}=-0,2 \mathrm{~V}, \Delta \lambda=10 \mathrm{~nm}$.

A hosszútávú fotoelektrolízist in-situ gázfázis-analízissel kombinálva hajtottunk végre annak érdekében, hogy nyomon tudjuk követni a $\mathrm{H}_{2}$ gáz fejlődését, valamint meg tudjuk vizsgálni a kompozitok stabilitását (36. ábra). A kezdeti szakaszon kismértékű sötétáram volt tapasztalható, amelyre a legvalószínübb magyarázat az, hogy kis mennyiségü Ni(III)-t redukálunk a mintában (amely a XPS méréseken is látszódott). A fotoáram lassan csökkent az elektrolízis során, ez részben a Pt nanorészecskék mintákból való kimosódásának köszönhető (ez megerősítést nyert XPS mérések által, amelyet elvégeztünk a hosszú távú elektrolízis előtt és után egyaránt).

A mérés megkezdését követően már az első mérési pontban (fél órát követően) detektálható mennyiségü $\mathrm{H}_{2}$ volt a gázfázisban. $\mathrm{A}_{2}$ mennyisége a gázfázisban az áthaladt töltéssel arányosan nőtt. A Faraday hatásfok a fotoelektrolízis során $70 \%$ volt. Ennek 
legvalószínübb oka, hogy kis mértékben szivárgott az elektrokémiai cella, így nem sikerült az összes $\mathrm{H}_{2}$-t detektálni. A különböző Pt mérettel készített kompozitokon is elvégeztük ezt a mérést, és minden esetben hasonló eredményeket kaptunk. A hosszú időtartamú elektrolízist követően a mintákat XPS segítségével vizsgáltuk. Ezen mérésekből azt a következtetést tudtuk levonni, hogy a Pt és a $\mathrm{NiO}$ kémiai állapota nem változik a folyamat során.
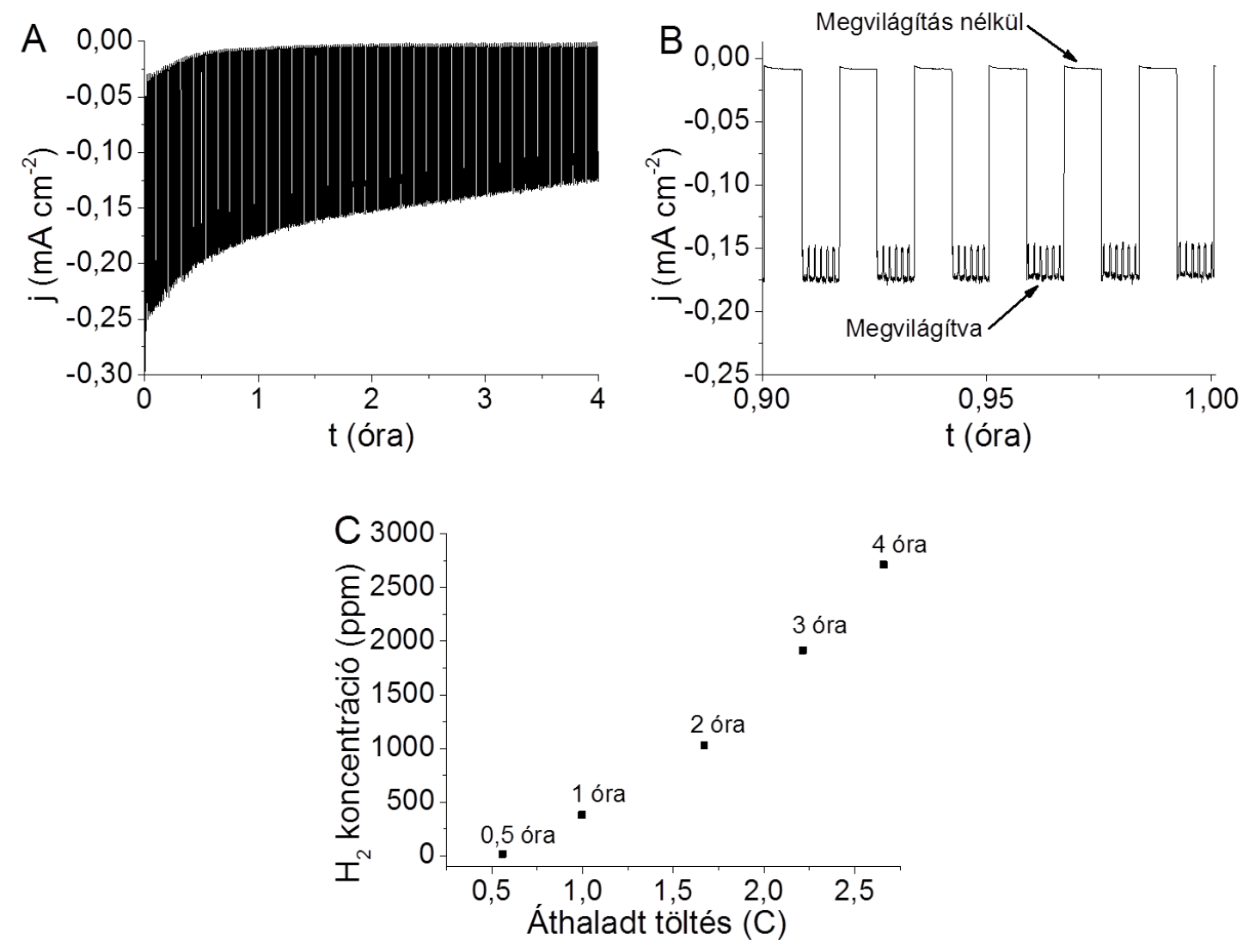

36. ábra: (A) Hosszútávú fotoelektrolízis a 7,2 nm-es Pt-val dekorált Pt/NiO rétegeken $(\mathrm{E}=-0,2 \mathrm{~V}) 0,2 \mathrm{M} \mathrm{Na}_{2} \mathrm{SO}_{4}$-ban. (B) A kronoamperometriás görbe kinagyított része 0,9-1 óra közötti tartományon. (C) A hosszútávú elektrolízis során képződő $\mathrm{H}_{2}$ mennyisége az áthaladt töltés függvényében.

\section{2. $\mathrm{CuCrO}_{2}$ fotoelektród előállítása és jellemzése}

\subsubsection{Szerkezeti jellemzés}

Röntgendiffraktometriás méréseket végeztünk annak érdekében, hogy a $\mathrm{CuCrO}_{2}$ minták kristályosságát és a fázisösszetételét jellemezzük. A minták minden $\mathrm{F} / \mathrm{O}$ aránynál kristályosak voltak, azonban az alkalmazott aránytól függően jelentősen változott a fázisösszetétel (37. ábra $\mathrm{A}$ ). Majdnem tiszta fázisú $\mathrm{CuCrO}_{2}$ állítottunk elő $0,5-0 ̈ \mathrm{~s} / \mathrm{O}$ aránynál (37. ábra B), a minta kis mennyiségü $\mathrm{CuO}(\sim 4 \mathrm{~m} / \mathrm{m} \%)$ és $\alpha-\mathrm{Cr}_{2} \mathrm{O}_{3}(\sim 6 \mathrm{~m} / \mathrm{m} \%)$ szennyeződést tartalmazott (38. ábra). 

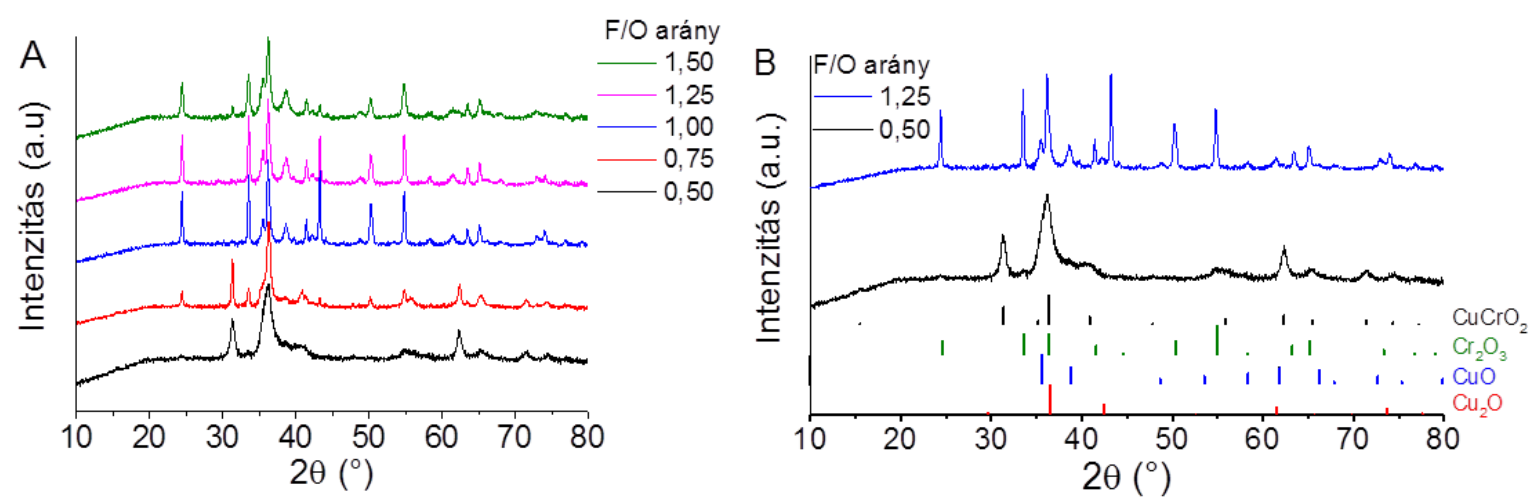

37. ábra: Az oxid minták röntgendiffraktogramja különböző $F / O$ arányoknál; $(B)$ a 0,5-ös és a 1,25-ös $\mathrm{F} / \mathrm{O}$ aránynál készült minták röntgendiffraktogramjai, valamint a komponensek referencia adatai $\left(\mathrm{CuCrO}_{2}, a-\mathrm{Cr}_{2} \mathrm{O}_{3}, \mathrm{CuO}\right.$, és $\left.\mathrm{Cu}_{2} \mathrm{O}\right)$. A láthatóság kedvéért a görbék el lettek tolva egymástól.

Érdekesség, hogy a $\mathrm{CuCrO}_{2}$-nak két kristályos fázismódosulata egyszerre létezett a mintában. A fő fázis $(\sim 61 \mathrm{~m} / \mathrm{m} \%)$ a $\overline{\mathrm{R}} 3 \mathrm{~m}$ (JCPDS \#89-6744) polimorf volt, míg a P63/mmc (JCPDS \#89-0540) fázis kisebb mennyiségben volt jelen ( $29 \mathrm{~m} / \mathrm{m} \%)$. Azáltal, hogy növeltük a $\mathrm{F} / \mathrm{O}$ arányt, föleg $\alpha-\mathrm{Cr}_{2} \mathrm{O}_{3}$ keletkezett. Amikor a $\mathrm{F} / \mathrm{O}$ arány 1 vagy nagyobb volt, akkor több fázis keveréke keletkezett (ezt Rietveld-felbontás segítségével igazoltuk). Ezek: $\mathrm{Cu}_{2} \mathrm{O}$ (JCPDS \#05-0667), $\mathrm{Cu}$ (JCPDS \#04-0836), $\mathrm{CuO}$ (JCPDS \#801917), és $\alpha-\mathrm{Cr}_{2} \mathrm{O}_{3}$ (JCPDS \#38-1479) voltak. Ezt a trendet a lánghőmérséklet változásának lehet tulajdonítani, amely a különböző F/O arányoknál eltérő [141].

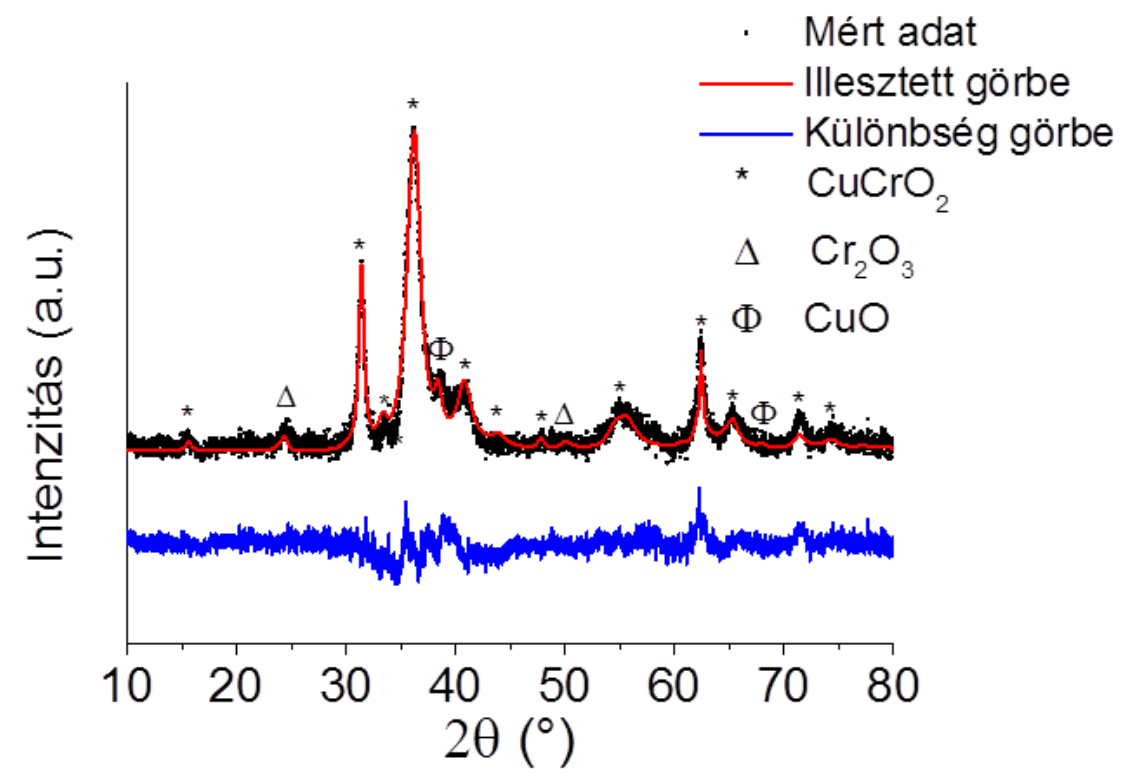

38. ábra: A $0,5 \mathrm{~F} / \mathrm{O}$ arány esetén készült oxid minta diffraktogramjának Rietveld felbontása.

A minták kristályosságának növelésének érdekében utólagos hőkezelést alkalmaztunk, egy órán keresztül Ar-ban vagy levegöben. Függetlenül attól, hogy milyen összetételből 
indultunk ki a $700{ }^{\circ} \mathrm{C}$-on levegőben való hökezelés során, a minták 3:1 tömeg arányú spinell szerkezetü $\mathrm{CuCr}_{2} \mathrm{O}_{4}$ (JCPDS \#34-0424) és $\mathrm{CuO}$ keverékévé alakultak (39. A, B ábra).

Az előzőekben tapasztalt jelenségnek a hajtóereje az, hogy a $\mathrm{Cu}^{+}$ion $\mathrm{Cu}^{2+}$-vé oxidálódik a kristályrácsban oxigén jelenlétében $450{ }^{\circ} \mathrm{C}$ hőmérséklet felett [49]. Annak érdekében, hogy elkerüljük a $\mathrm{Cu}^{+}$oxidációját, a mintákat inert $\mathrm{Ar}$ atmoszférában is hőkezeltük. Ezek között a körülmények között, a 0,5 F/O-nál szintetizált minta megőrizte a delafosszit szerkezetét, és a hökezeletlen mintához képest kisebb mennyiségü egyfémes oxidot detektáltunk a szerkezetében (40. ábra).
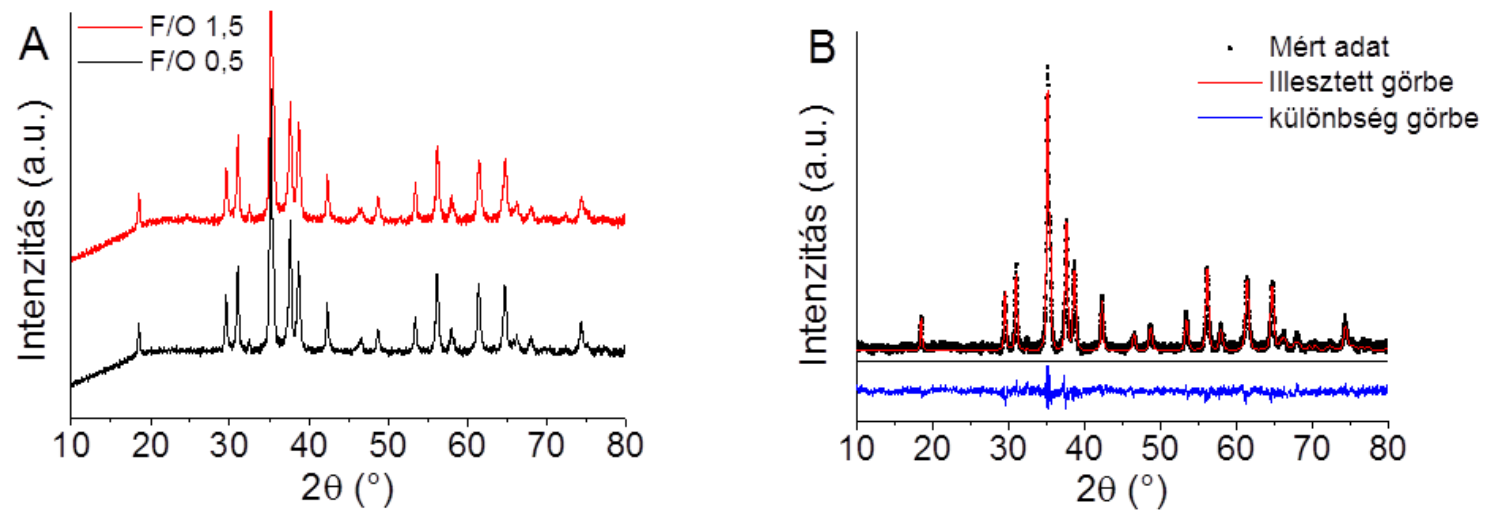

39. ábra: (A) A különböző $\mathrm{F} / \mathrm{O}-$ nál elöállított minták röntgendiffraktogramjai melyeket levegőn hőkezeltünk $700{ }^{\circ} \mathrm{C}$-on 1 órán keresztül. . A láthatóság kedvéért a görbék el lettek tolva egymástól. (B) A 0,5 F/O aránynál készült minta Rietveld felbontása, amelyet levegőn hőkezeltünk.

A hőkezelés hőmérsékletének emelésével elérhető volt, hogy a kisebbségi fázisok mennyisége fokozatosan csökkenjen a termékben. Ehhez két különböző folyamat vezethetett: (i) a $\mathrm{CuO}$ és $\alpha-\mathrm{Cr}_{2} \mathrm{O}_{3}$ átalakulása $\mathrm{CuCrO}_{2}$-á, valamint (ii) a $\mathrm{P} 63 / \mathrm{mmc}$ kisebbségi fázis átalakulása $\overline{\mathrm{R}} 3 \mathrm{~m}$ fázissá [142]. 


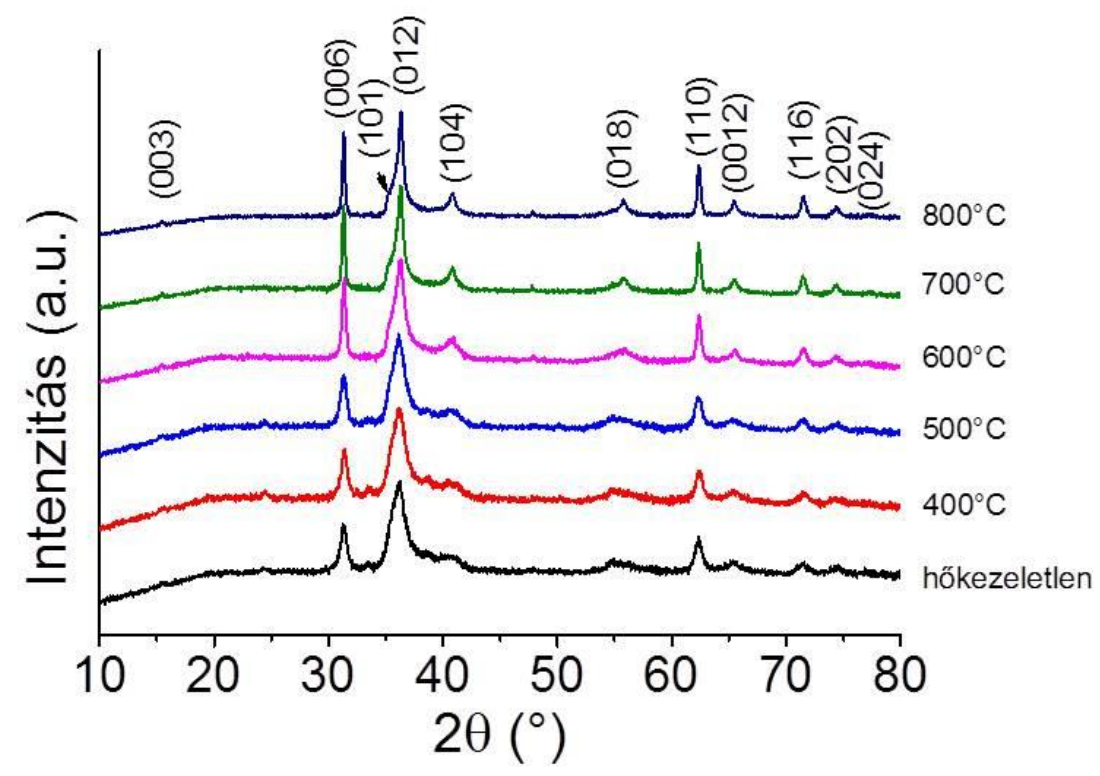

40. ábra: Ar atmoszférában, különböző hőmérsékleteken hőkezelt, 0,5 F/O aránynál készült $\mathrm{CuCrO}_{2}$ minták röntgendiffraktogramjai.

Az összetétel változás mellett, a hőkezelés hatással volt a kristályos domének méretére, amelyet a teljes diffraktogrammra való illesztés segítségével határoztunk meg. Figyelembe vettünk minden krisztallográfiai irányt (az átlag kristály átméröt adtuk meg), és ezzel a módszerrel a müszer által okozott hibát is ki tudtuk küszöbölni. Az átlagos domén méret $11 \mathrm{~nm}$ volt a hökezelés elötti minták esetén. A hömérséklet emelésének csak $500{ }^{\circ} \mathrm{C}$ felett volt hatása. Amennyiben tovább növeltük a hömérsékletet, a domén méret is növekedett. A legmagasabb hőmérsékleten $\left(T=800^{\circ} \mathrm{C}\right)$ a kristályos domének átlagos mérete $31 \mathrm{~nm}$ volt (41. ábra).

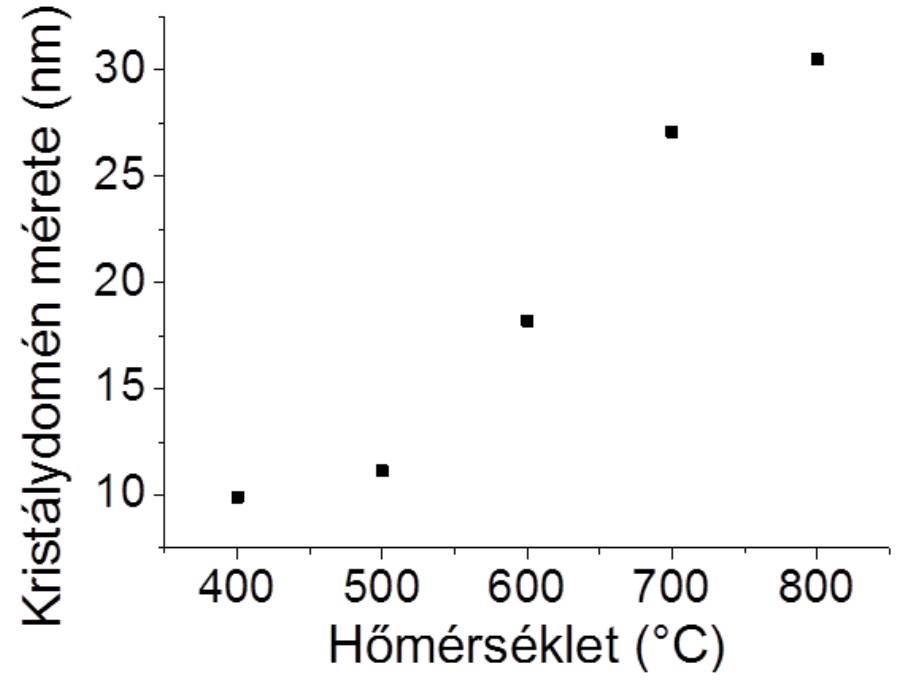

41. ábra: $\mathrm{A}$ hőmérséklet hatása a $\mathrm{CuCrO}_{2}$ kristálydomén mérete $(0,5 \mathrm{~F} / \mathrm{O}$ aránynál készült $\mathrm{CuCrO}_{2}, 1$ óra Ar-ban való hökezelést követően). A domén méretének változásai az egész diffraktogram illesztése alapján lettek meghatározva. 
Annak érdekében, hogy bizonyítsuk a belobbantásos reakció szerepét, a szintézist végrehajtottuk üzemanyag hozzáadása nélkül is. Ezzel egy egyszerü együttes lecsapást hajtottunk végre, amely során a fém prekurzorokat feloldottuk, majd az oldatokat alaposan összekevertük, és végül $350{ }^{\circ} \mathrm{C}$-ra elömelegített fözőlapra helyeztük. A szintézist követően a kapott termék barna volt, és $\mathrm{CuCrO}_{4}$-ként (JCPDS \#34-0507) tudtuk azonosítani röntgendiffraktometria segítségével (42. ábra). Ezt követően, $700{ }^{\circ} \mathrm{C}$-on hökezeltük $\mathrm{Ar}$ atmoszférában (hasonlóan a $\mathrm{CuCrO}_{2}$ mintákhoz). Az így előállított minta föleg spinell szerkezetü $\mathrm{CuCr}_{2} \mathrm{O}_{4}$-t, $\alpha-\mathrm{Cr}_{2} \mathrm{O}_{3-\mathrm{t}}$ tartalmazott, a $\mathrm{CuCrO}_{2}$ csak kisebbségi fázisként volt azonosítható. Ez bizonyítja, hogy a SCS valóban egy olyan eljárás, aminek a segítségével majdnem fázistiszta delafosszit szerkezetü $\mathrm{CuCrO}_{2}$ állítható elő. Az összes további kísérlet során csak a 0,5 F/O aránynál készített $\mathrm{CuCrO}_{2}$-t (mind a hökezeletlen, mind az Ar-ban, $700^{\circ} \mathrm{C}$-on hőkezelt mintákat) vizsgáltuk.

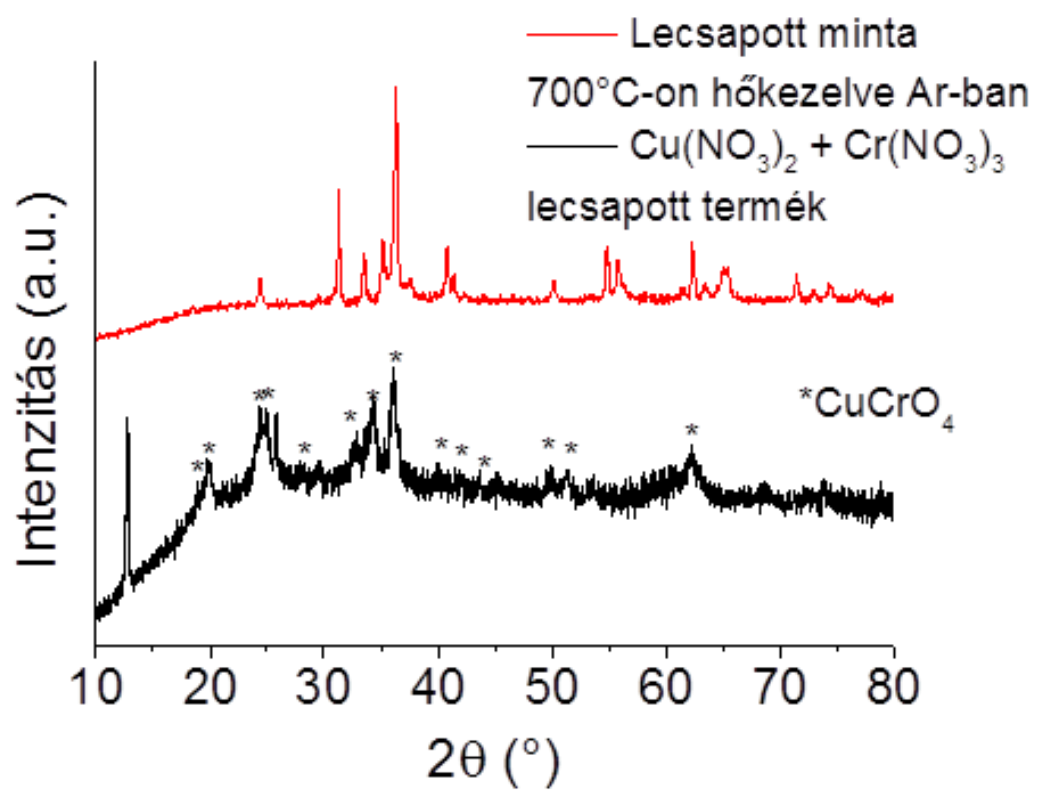

42. ábra: $\mathrm{Az}$ együttes lecsapással készült hőkezeletlen és hőkezelt minták röntgendiffraktogramjai $\left(700^{\circ} \mathrm{C}\right.$-on 1 órán keresztül Ar atmoszférában).

Pásztázó elektronmikroszkópiás felvételeket készítettünk annak érdekében, hogy jellemezzük a minták morfológiáját (43. ábra). A hőkezeletlen minták esetében mikrométeres nagyságú pórusos struktúrákat figyeltünk meg, melyek kisebb, szorosan összekapcsolódott $\mathrm{CuCrO}_{2}$ nanorészecskékből épültek fel. A mintát hőkezelésnek alávetve teljesen más morfológia alakult ki: a pórusos szerkezet eltünt, és a nagyobb méretü szemcsék összeolvadtak.

Az elöbbi trendek tükröződtek a fajlagos felület értékében is. Amíg a hőkezeletlen minta fajlagos felülete $36,2 \mathrm{~m}^{2} \mathrm{~g}^{-1}$ (a BET egyenletből számolva), addig a hőkezelést 
követően az 9,9 $\mathrm{m}^{2} \mathrm{~g}^{-1}$-ra csökkent. Amikor a $\mathrm{CuCrO}_{2}$-t porlasztva fújásos technika segítségével üvegszén elektród (GC) felszínére vittük fel, akkor a hőkezelést követően megmaradt a $\mathrm{CuCrO}_{2}$ eredeti struktúrája.

EDX méréseket végeztünk a minták elemi összetételének felderítésére. $\mathrm{A} \mathrm{Cu} \mathrm{Cr}$ atom aránya $(1,06 \pm 0,02):(0,94 \pm 0,02)$ volt a mintákban, ami jó egyezést mutat az elméleti aránnyal. Ezen mérések arról is információt adtak, hogy a hőkezelést követően nincs szénszennyeződés a mintában.
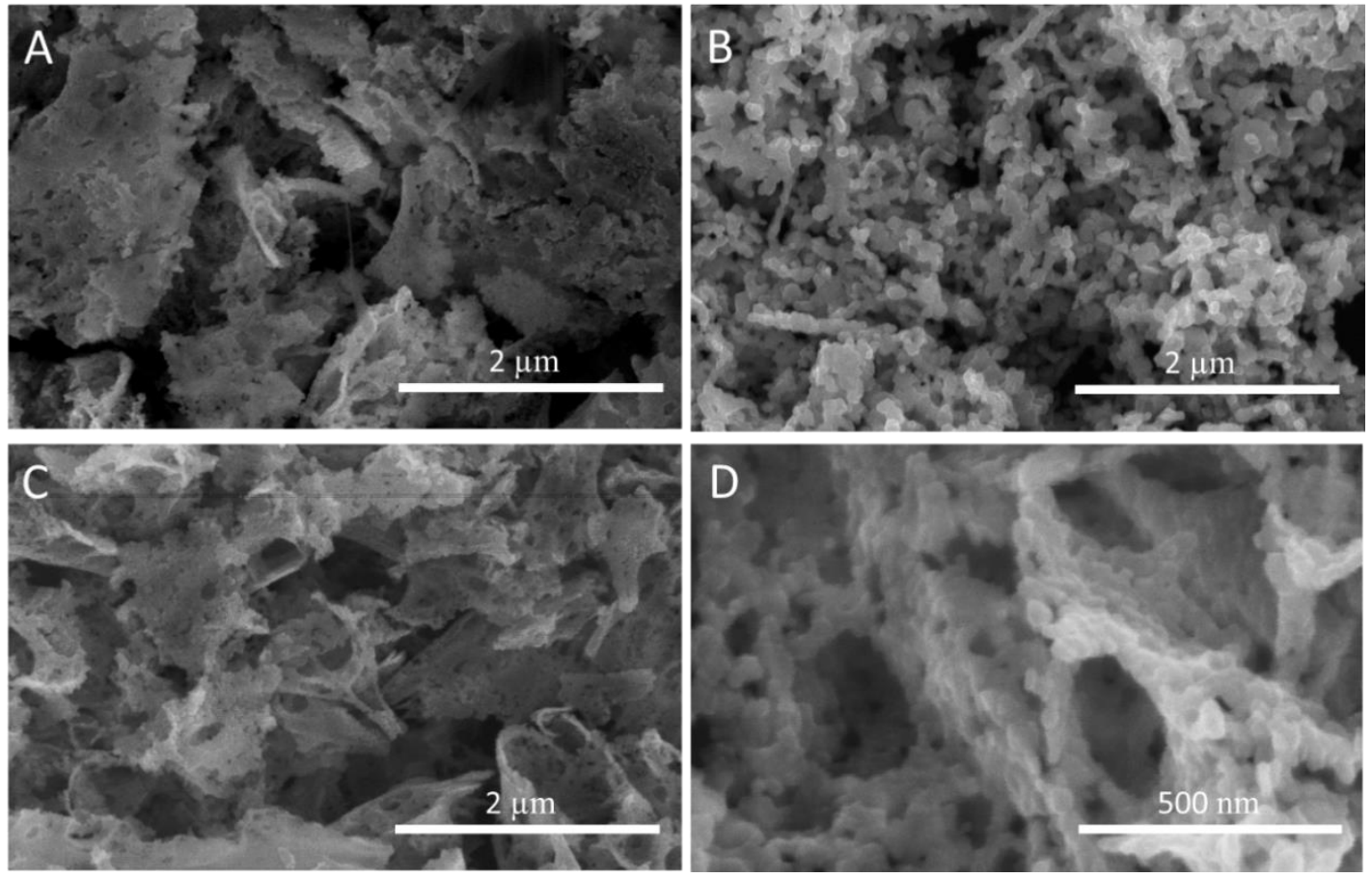

43. ábra: $\mathrm{A}$ 0,5 F/O aránynál készült $\mathrm{CuCrO}_{2}$ SEM felvételei: (A) Hőkezelés nélkül; (B) $700{ }^{\circ} \mathrm{C}$-on 1 órán keresztül hőkezelést követően; (C-D) $700{ }^{\circ} \mathrm{C}$-on 1 órán keresztül Ar atmoszférában hőkezelt minta, amely hőkezelés előtt üvegszén elektród felszínre volt felfújva.

A hőkezelést megelőzően és az azt követően készített TEM felvételek (44. ábra) megerősítik a SEM mérések eredményeit, mint pl. a szorosan összekapcsolódott szerkezetet.

A primer nanorészecskék méreteloszlásának meghatározása érdekében, 300 egyedi nanorészecske átmérőjét mértük meg. A hőkezelés előtt a $\mathrm{CuCrO}_{2}$ átlagos részecskemérete $27 \pm 9 \mathrm{~nm}$ volt, a hőkezelést követően ez $35 \pm 9$ nm-re változott (45. ábra). Összehasonlítva ezeket az értékeket azokkal a kristálydomén méretekkel, amelyeket az XRD mérésekből kaptunk, egy érdekes tendenciát figyeltünk meg. 

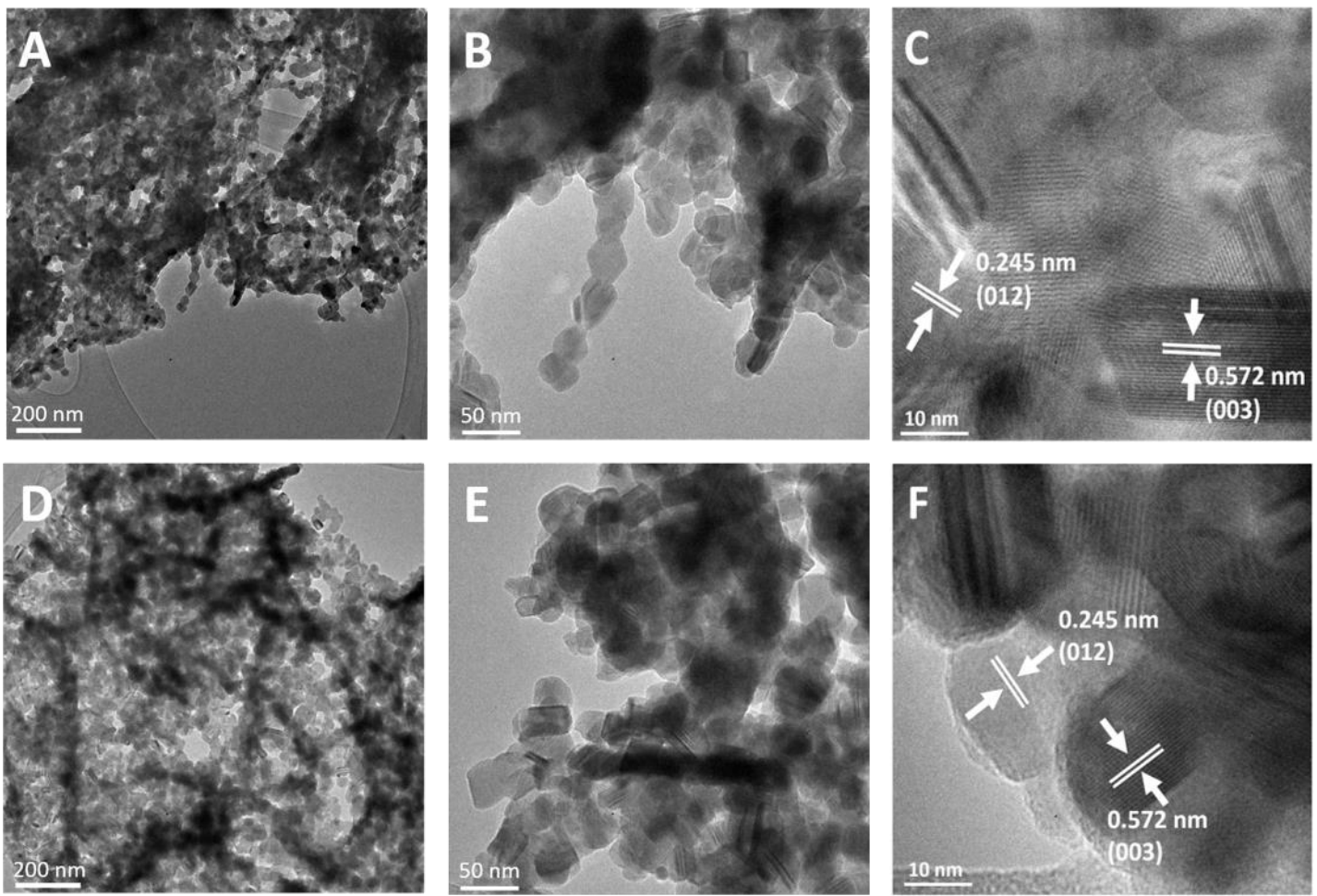

44. ábra: $\mathrm{A}$ 0,5 F/O aránynál készült $\mathrm{CuCrO}_{2}$ TEM és HR-TEM felvételei; (A-C) hőkezelés előtt, (D-F) hökezelést követően $\mathrm{GC}$ felületén $700{ }^{\circ} \mathrm{C}$-on $\mathrm{Ar}$ atmoszférában 1 órán keresztül. A nagyfelbontású TEM képeken a kristálysíkok a $\mathrm{CuCrO}_{2}$-hoz rendelhetőek.

Kisebb hőmérsékleten a kristály domén mérete jelentősen kisebb, mint az átlagos részecskeméret. A hőkezelés hőmérsékletének növekedésével a részecske méret egyre jobban közelít a $800^{\circ} \mathrm{C}$-on hőkezelt mintánál meghatározott domén méretéhez (41. ábra). Ez a trend azt jelzi, hogy a nagyobb hőkezelési hőmérséklet elsősorban a nanorészecskék kristályosodását segíti elő.
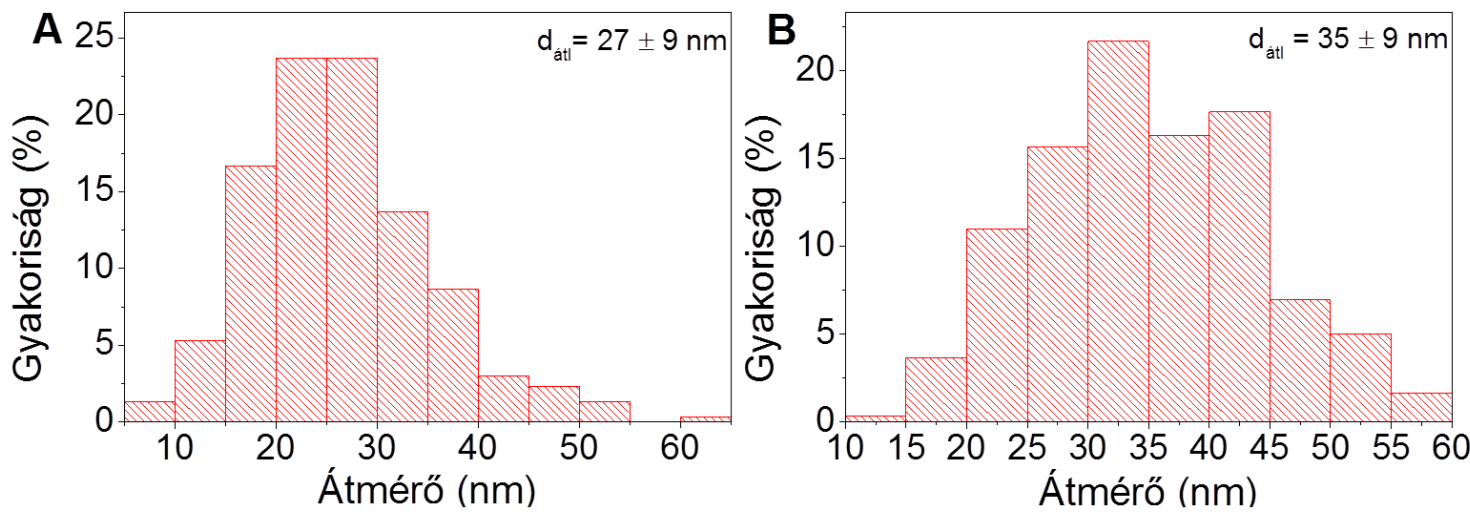

45. ábra: $0,5 \mathrm{~F} / \mathrm{O}$ aránynál készített $\mathrm{CuCrO}_{2}$ részecskeméret-eloszlása $(\mathrm{A})$ hőkezelés elött; és (B) $700{ }^{\circ} \mathrm{C}$-on 1 órás Ar atmoszférában való hőkezelést követően, üvegszén felszínén lévő $\mathrm{CuCrO}_{2}$ minta esetén. 
Nagy felbontású TEM felvételeket készítettünk, hogy megfigyeljük a delafosszitra jellemző kristálysíkokat. Mind a hőkezelés előtt és után a $\overline{\mathrm{R}} 3 \mathrm{~m} \mathrm{CuCrO}_{2}$-nak (012) és (003) kristálysíkjait tudtuk azonosítani (44. ábra $\mathrm{C}, \mathrm{F}$ ). Bizonyos területeken a $\mathrm{Cr}_{2} \mathrm{O}_{3}$-hoz és CuO-hoz tartozó kristálysíkok is megtalálhatóak (46. ábra).

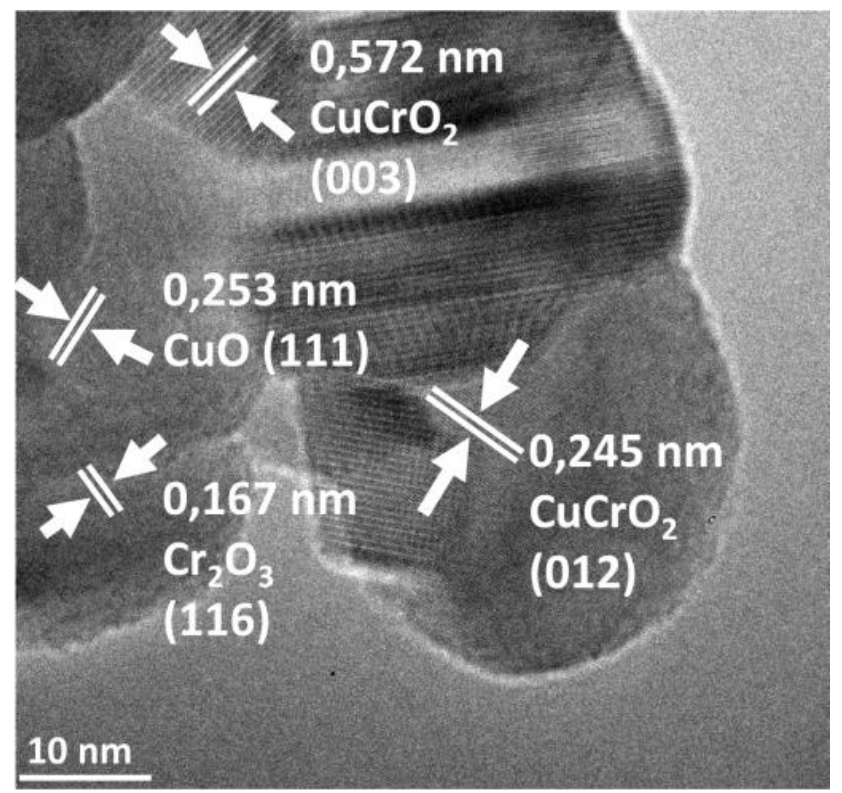

46. ábra: $\mathrm{A} \quad 0,5 \mathrm{~F} / \mathrm{O}$ aránynál készült, nem hőkezelt $\mathrm{CuCrO}_{2}$ nagyfelbontású TEM felvétele.

A $\mathrm{CuCrO}_{2}$ minták fizikai tulajdonságainak jellemzésére UV-látható diffúz reflexiós, Raman és infravörös spektroszkópiás vizsgálatokat végeztünk. A tiltottsáv-szélességnek a meghatározásához Tauc görbét használtunk, feltételezve, hogy a $\mathrm{CuCrO}_{2}$ mintáknak direkt tiltottsáv-átmenettel rendelkeznek [48]. Az optikai tiltottsáv-szélesség 2,82 eV-nek adódott (47. ábra B), ami kisebb, mint a szakirodalomban közölt érték (3,15 eV) [48]. Figyelembe véve a szakirodalomban megtalálható, kétfémes oxidokra megadott értékek változatosságát [143], a tiltottsáv-szélességben tapasztalható ilyen mértékü különbségek nem meglepőek. A diffúz reflexiós spektrumon kisebb sávok is találhatóak (458 és 594 nm), közel a fó abszorbancia csúcshoz (368 nm). Ezek a sávok a szerkezetben található oktaéderes $\mathrm{Cr}^{3+} \mathrm{d}$ d átmenetéhez köthetőek [66]. 

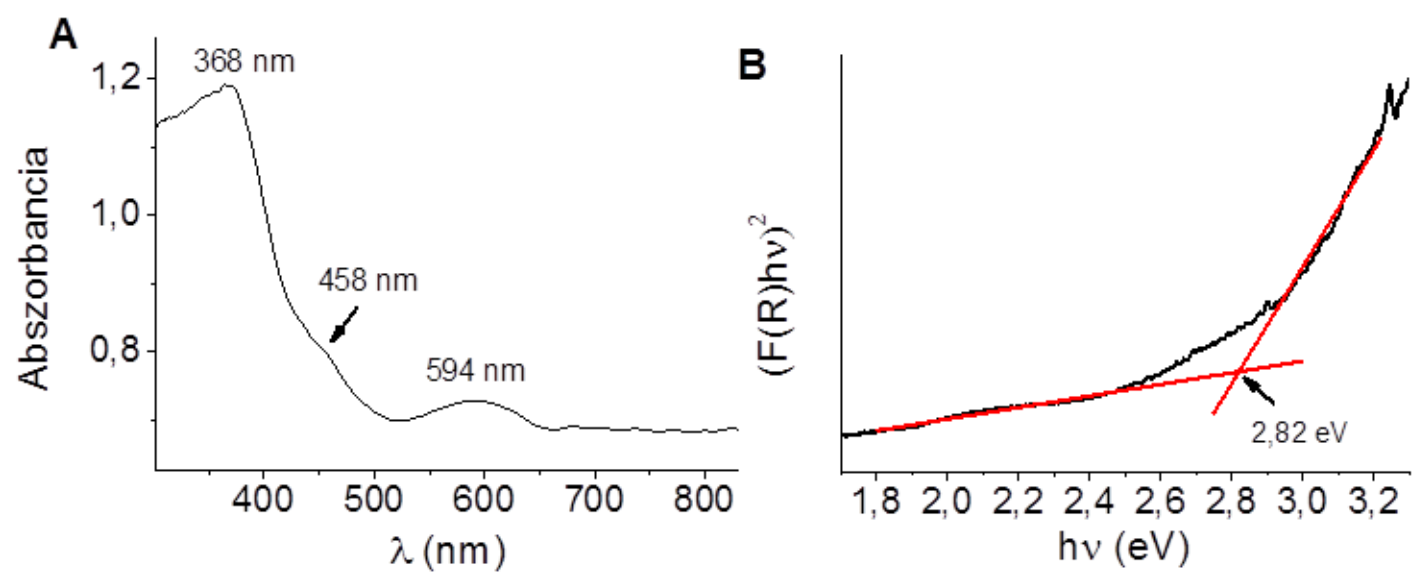

47. ábra: (A) $0,5 \mathrm{~F} / \mathrm{O}$ aránynál elöállított, $700{ }^{\circ} \mathrm{C}$-on 1 órán keresztül $\mathrm{Ar}$ atmoszférában hőkezelt $\mathrm{CuCrO}_{2}$ UV-látható diffúz reflektancia spektruma. (B) A származtatott Tauc görbe a direkt tiltott-sávszélesség meghatározásához

A Raman spektrumokon látható, hogy a $\mathrm{Cu}_{2} \mathrm{O}$-nak három fö Raman modusa van 142 , 216 és $630 \mathrm{~cm}^{-1}$-nél [34], míg az $\alpha-\mathrm{Cr}_{2} \mathrm{O}_{3}$ csúcsai 304, 347, 549 és $605 \mathrm{~cm}^{-1}$-nél [144] találhatóak (48. ábra A). A $\mathrm{CuCrO}_{2}$ fö Raman modusai $\left(\mathrm{E}_{\mathrm{g}}, \mathrm{A}_{1 \mathrm{~g}}\right) 448 \mathrm{~cm}^{-1}$-nél és $694 \mathrm{~cm}^{-1}$ nél helyezkednek el, amely jó egyezést mutat a szakirodalomban található eredményekkel [145]. A kereskedelmi forgalomban kapható $\mathrm{Cu}_{2} \mathrm{O}$-nak és $\alpha-\mathrm{Cr}_{2} \mathrm{O}_{3}$-nak nincs közös modusa az általunk elöállított $\mathrm{CuCrO}_{2}$-al. Csak egy Raman modus $\left(547 \mathrm{~cm}^{-1}\right)$ van közel az $\alpha-\mathrm{Cr}_{2} \mathrm{O}_{3}$ legintenzívebb sávjához, ami valószínűleg egy rácsközi oxigénhez vagy a $\mathrm{Cu}$ helyén egy oktaéderesen koordinálódott $\mathrm{Cr}^{3+}$-hoz köthető (48. ábra A) [146]. Ugyanezen a por mintákon FT-IR méréseket is végeztünk. A $\mathrm{Cu}_{2} \mathrm{O}$-nak egy fö rezgése van $592 \mathrm{~cm}^{-1}$-nél [147], amíg a $\alpha-\mathrm{Cr}_{2} \mathrm{O}_{3}$ esetén három intenzív rezgés figyelhető meg 442, 507, és $608 \mathrm{~cm}^{-1}$ nél [144]. A $\mathrm{CuCrO}_{2}$ rezgései 500 és $712 \mathrm{~cm}^{-1}$-nél jelentek meg, ami jól egyezik szakirodalmi értékekkel (48. ábra B) [148].
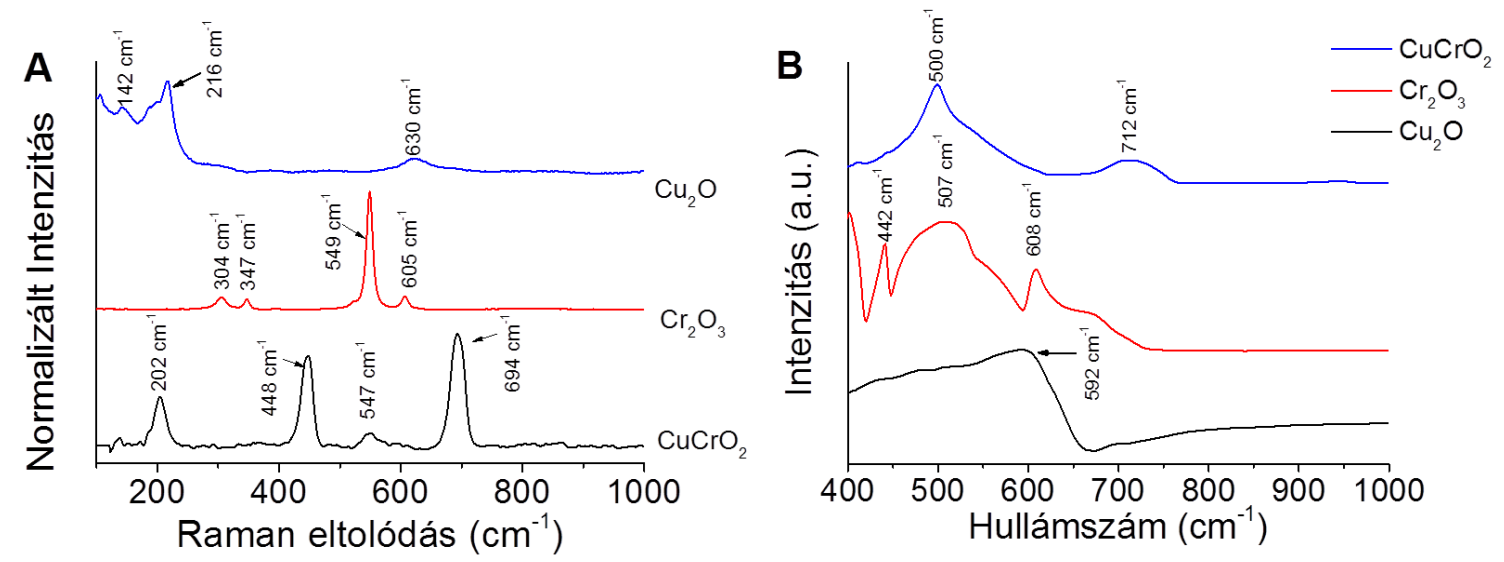

48. ábra: $\mathrm{A}$ kereskedelmi forgalomban kapható $\mathrm{Cu}_{2} \mathrm{O}$ és $\mathrm{Cr}_{2} \mathrm{O}_{3}$ és a $0,5 \mathrm{~F} / \mathrm{O}$ aránynál szintetizált hőkezeletlen $\mathrm{CuCrO}_{2}$ (A) Raman és (B) FT-IR spektrumai. A láthatóság kedvéért a görbék el lettek tolva egymástól. 


\subsubsection{Fotoelektrokémiai tulajdonságok}

Az anyagok fotoelektrokémiai aktivitását pásztázó lineáris fotovoltammetriával vizsgáltuk UV-látható fény megvilágítás mellett. A méréseket nitrogénnel buborékoltatott $0,1 \mathrm{~mol} \mathrm{dm}^{-3} \mathrm{Na}_{2} \mathrm{SO}_{4}$ oldatban és $\mathrm{CO}_{2}$-al telített $\mathrm{NaHCO}_{3}$-ban is elvégeztük, hogy közel azonos kémhatású oldatban vizsgálhassuk a $\mathrm{CO}_{2}$ és a víz redukcióját (49. ábra $\mathrm{A}$ ). Amennyiben ugyanazokon a rétegen végeztük el a méréseket a két különböző oldatban, akkor a legfontosabb különbségként azt tapasztaltuk, hogy: (i) körülbelül kétszer nagyobb fotoáramok mérhetőek $\mathrm{CO}_{2}$ jelenlétében, mint $\mathrm{N}_{2}$-ben, (ii) $\mathrm{CO}_{2}$-al telített oldatban a fotoáram megindulási (onset) potenciálja eltolódott a pozitívabb potenciálok felé $(E=$ $+1,12 \mathrm{~V} \mathrm{CO}_{2}$-ban vs. $+0,96 \mathrm{~V} \mathrm{~N}_{2}$-ben vs. RHE). Ezek a megfigyelések arra mutatnak, hogy egy többlet folyamat játszódik le a $\mathrm{CO}_{2}$-al telített oldatban (a vízredukción felül, amely mindkét oldatban lejátszódik).

Annak érdekében, hogy a kereskedelmi forgalomban kapható $\mathrm{Cu}_{2} \mathrm{O}, \alpha-\mathrm{Cr}_{2} \mathrm{O}_{3}$, és az általunk szintetizált $\mathrm{CuCrO}_{2}$-nak a fotoelektrokémiai tulajdonságait összehasonlítsuk, lineáris pásztázó fotovoltammetriával vizsgáltuk a mintákat (49. ábra $\mathrm{B}$ ). $\mathrm{A} \quad \mathrm{Cu}_{2} \mathrm{O}$ fotoelektródokat a szuszpenzió felfújása segítségével készítettük, amelyen kisebb fotoáramok voltak mérhetőek ezen a potenciál tartományon, mint a $\mathrm{CuCrO}_{2}-\mathrm{n}$. Ez valószínűsíthetően a részecske/részecske határfelületen végbemenő töltéshordozó rekombinációnak, valamint a kisebb fajlagos felületnek köszönhető. Fontos megjegyezni, hogy a nem kereskedelmi forgalomban kapható, elektrokémiai leválasztással készített $\mathrm{Cu}_{2} \mathrm{O}$ minták esetén ennél sokkal nagyobb fotoáramokat mértek [149-152].

\section{A}

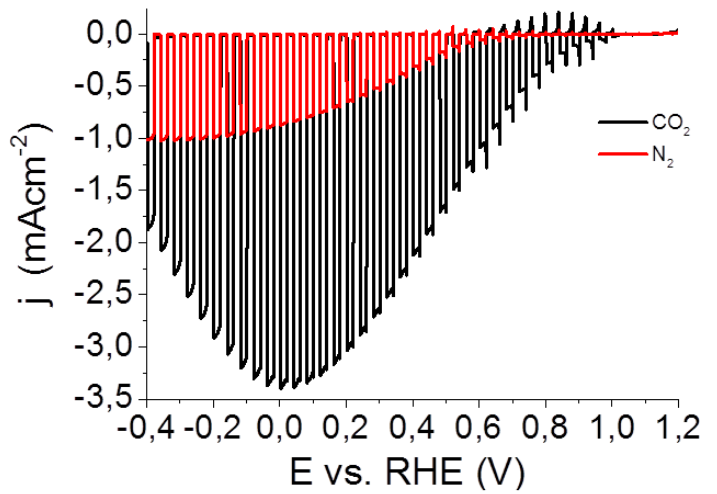

B

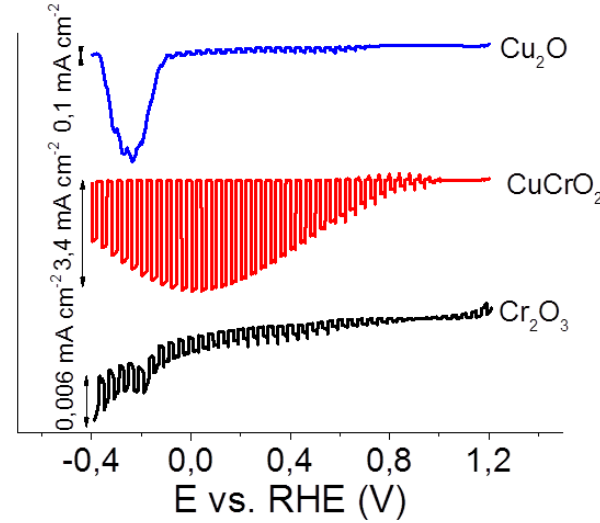

49. ábra: (A) $\mathrm{CO}_{2}$-al telített $0,1 \mathrm{M} \mathrm{NaHCO}_{3}$-ban, valamint $\mathrm{N}_{2}$-el öblített $0,1 \mathrm{M} \mathrm{Na}_{2} \mathrm{SO}_{4}$ oldatban mért $\mathrm{CuCrO}_{2}$ lineáris pásztázó fotovoltammetriás görbéi. (B) $\mathrm{CO}_{2}$-al telített $0,1 \mathrm{M}$ $\mathrm{NaHCO}_{3}$ elektrolitban a kereskedelmi $\mathrm{Cu}_{2} \mathrm{O}$-nak és a $\mathrm{Cr}_{2} \mathrm{O}_{3}$-nak, valamint a $\mathrm{CuCrO}_{2}$-nak $\left(0,5 \mathrm{~F} / \mathrm{O}\right.$ aránynál szintetizált és $700{ }^{\circ} \mathrm{C}$-on 1 órán keresztül hőkezelt) lineáris pásztázó fotovoltammetriás görbéi (minden esetben a felfújt tömeg $0,1 \mathrm{mg} \mathrm{cm} \mathrm{cm}^{-2}$ ), $2 \mathrm{mV} \mathrm{s}^{-1}$ pásztázási sebesség és $0,1 \mathrm{~Hz}$-es fényszaggatás mellett. 
Negatívabb potenciálokon $(-0,1 \mathrm{~V}$ alatt $)$ a $\mathrm{Cu}_{2} \mathrm{O}$ esetén a sötétáram növekedése tapasztalható. $\mathrm{Ez}$ a $\mathrm{Cu}_{2} \mathrm{O}$ fém rézzé való redukciójához köthető [34,38]. $\mathrm{A} \mathrm{CuCrO}_{2}$-nál nem tapasztaltunk korrózióhoz köthető sötétáramot (50.ábra) még abban az esetben sem, amikor méréseinket egy szélesebb potenciáltartományban végeztük el. Negatív potenciálon azonban megfigyelhető egy sötétáram növekedése, amely a víz elektrokémiai redukciós folyamathoz köthető. Ez azonban jóval negatívabb potenciálon indul el mint a $\mathrm{Cu}_{2} \mathrm{O}$-on . Ellentétben a $\mathrm{CuCrO}_{2}$-al és a $\mathrm{Cu}_{2} \mathrm{O}$-al, az $\alpha-\mathrm{Cr}_{2} \mathrm{O}_{3}$ fotoelektrokémiai aktivitása ezen a potenciáltartományon elhanyagolható.

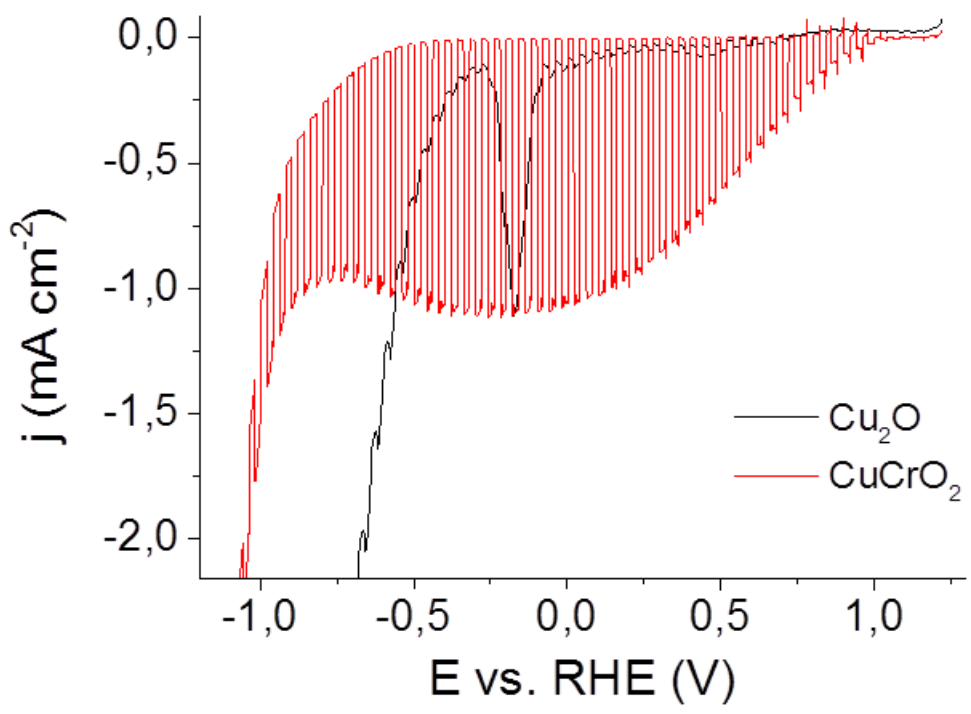

50. ábra: $\mathrm{CO}_{2}$-al telített $0,1 \mathrm{M} \mathrm{NaHCO} 3^{-}$oldatban $\mathrm{CuCrO}_{2}$ és $\mathrm{Cu}_{2} \mathrm{O}$ lineáris pásztázó fotovoltamogrammjai, $2 \mathrm{mV} \mathrm{s}{ }^{-1}$ pásztázási sebesség mellett. Mindkét esetben a felvitt tömegek azonosak $\left(0,1 \mathrm{mg} \mathrm{cm}^{-2}\right)$. A fényszaggatás frekvenciája $0,1 \mathrm{~Hz}$ volt.

Annak érdekében, hogy meghatározzuk a $\mathrm{CuCrO}_{2}$ sima sáv potenciálját (amely közel van a vegyértéksávhoz a p-típusú félvezetők esetén), elektrokémiai impedancia spektroszkópiás méréseket végeztünk (51. ábra A). A negatív meredekség a Mott-Schottky görbéken azt mutatja, hogy az elöállított anyag p-típusú félvezetőként viselkedik. Az $\mathrm{E}_{\mathrm{FB}}=1,35 \mathrm{~V}$ érték adódott, amely jó egyezést mutat azzal értékkel, amelyet a fotoáram megindulási potenciáljából határoztunk meg.

A tiltottsáv-szélesség meghatározásához rögzítettük az $\mathrm{CuCrO}_{2}$ IPCE görbéjét (51. ábra B). Az IPCE értékek csökkentek, ahogy közeledtünk a látható hullámhosszúságú fény tartományához, és 438 nm körül a fotoaktivitás megszünt. Az ebből számolt tiltottsávszélesség 2,83 eV-nak felel meg, amely nagyon jó egyezést ad az optikai spektroszkópiával meghatározott értékkel $(2,82 \mathrm{eV})$. 

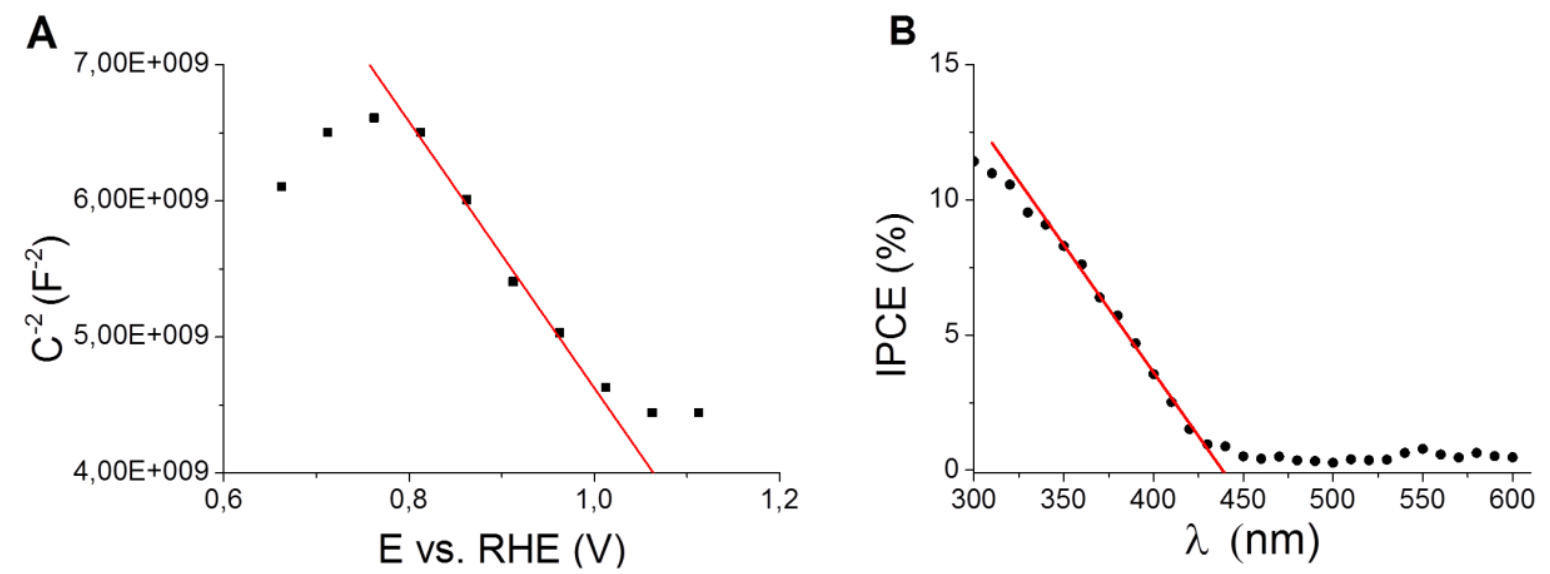

51. ábra: (A) Egy $\mathrm{CuCrO}_{2}$ elektródra mért Mott-Schottky görbe. $(0,5 \mathrm{~F} / \mathrm{O}$ aránynál szintetizált, $700{ }^{\circ} \mathrm{C}$-on 1 órán keresztül hőkezelt minta) az illesztett EIS adatból $0,1 \mathrm{M}$ $\mathrm{NaHCO}_{3}$ elektrolitban, (B) $\mathrm{CuCrO}_{2}$ IPCE görbéje $\left(\mathrm{CO}_{2}\right.$-al telített $0,1 \mathrm{M} \mathrm{NaHCO}$ oldatban).

A $\mathrm{CuCrO}_{2}$ rétegek fotoaktivitását szimulált napfénnyel való megvilágítás mellett is vizsgáltuk. A megfigyelt fotoáram-csökkenés (összehasonlítva az UV megvilágításhoz képest) azt jelzi, hogy a $\mathrm{CuCrO}_{2}$ valóban az UV tartományban nyel el, és ezen megvilágítás mellett nagyobb fotoaktivitást mutat (52. ábra).

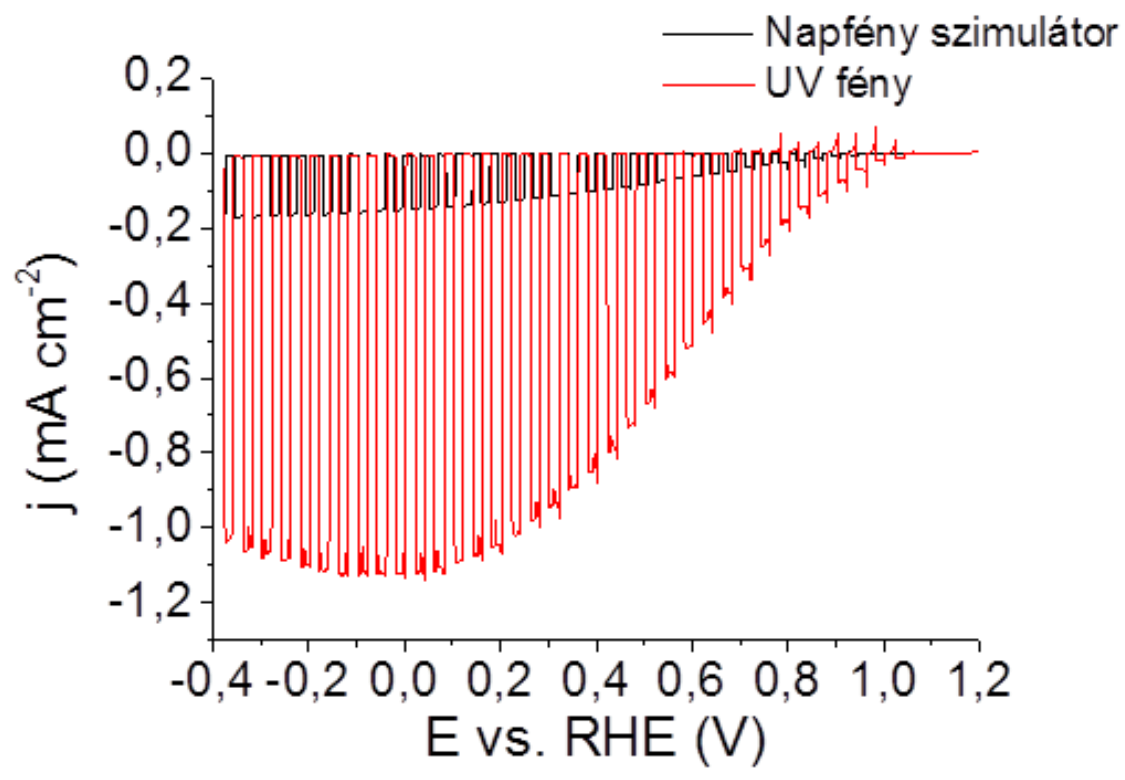

52. ábra: $0,5 \mathrm{~F} / \mathrm{O}$ aránynál szintetizált, és $700{ }^{\circ} \mathrm{C}$-on, 1 órán keresztül hőkezelt $\mathrm{CuCrO}_{2}$-réteg lineáris fotovoltamogrammjai, $2 \mathrm{mV} \mathrm{s}^{-1}$ pásztázási sebesség mellett, különböző fényforrásokat alkalmazva $\mathrm{CO}_{2}$-al telített $0,1 \mathrm{M} \mathrm{NaHCO}_{3}$ oldatban. A fényszaggatás frekvenciája $0,1 \mathrm{~Hz}$ volt.

A rétegvastagság fotoelektrokémiai viselkedésre gyakorolt hatását $0,05-0,5 \mathrm{mg} \mathrm{cm}^{-2}$ felületi borítottság tartományon vizsgáltuk Az elektródok tömegét felfújás előtt és felfújás után mikromérlegen mértük. Az optimális felszíni borítottság $0,1 \mathrm{mg} \mathrm{cm}^{-2}$-nek adódott (54. ábra). 


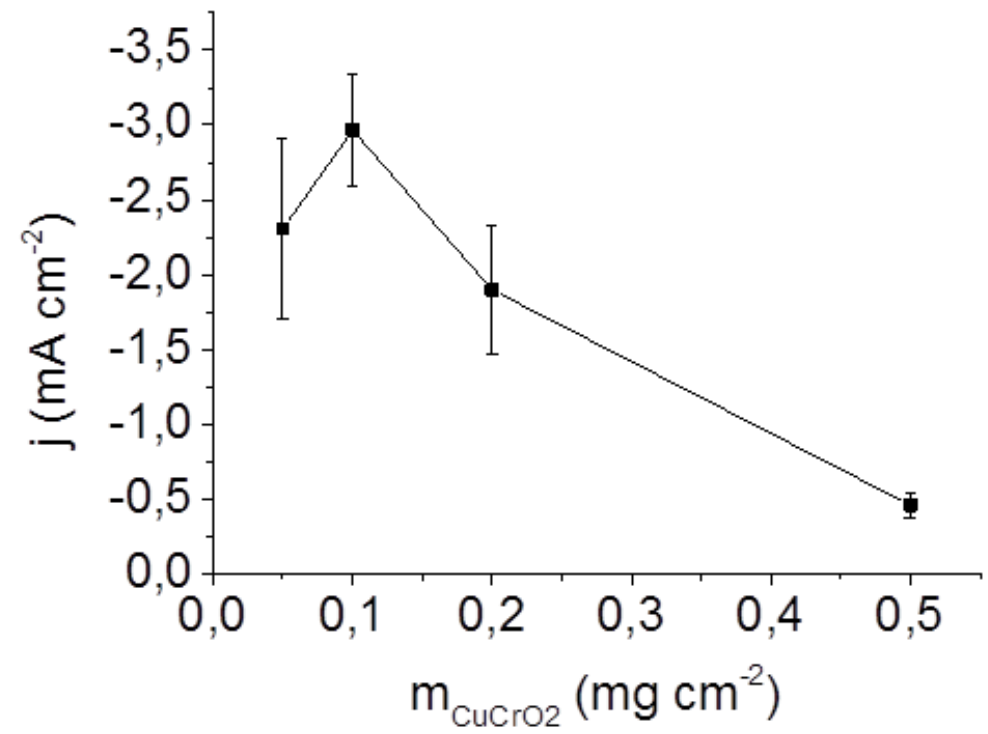

53. ábra: Az LSV görbékről $-0,1 \mathrm{~V}$ potenciálon leolvasott fotoáram függése a $\mathrm{CuCrO}_{2}$ $\left(0,5 \mathrm{~F} / \mathrm{O}\right.$ aránynál készült, $700{ }^{\circ} \mathrm{C} 1$ órán keresztül hökezelt minta) a felvitt anyag mennyiségétől, $\mathrm{CO}_{2}$-al telített $0,1 \mathrm{M} \mathrm{NaHCO}_{3}$ oldatban. A hibasávok három különböző elektródokon mért eredményeket reprezentálják.

A $\mathrm{CuCrO}_{2}$ a maximális fotoáramot kb. $-0,1 \mathrm{~V}$ potenciálon (vs. RHE) érte el, és a legjobban teljesítő elektródon mért fotoáram sürüsége $-3,4 \mathrm{~mA} \mathrm{~cm}{ }^{-2}$ volt. Fontos megjegyezni, hogy a vizsgált potenciáltartományon nem tapasztaltuk egyszer sem sötét áram megjelentését.

Az elektród vastagságát keresztmetszeti SEM felvételekből határoztuk meg. A rétegvastagság néhány mikrométernek adódott, ami sokkal nagyobb, mint a 0,17 $\mu$ m elméleti vastagság (ezt az anyag sürüségéből számoltuk, feltételezve, hogy tökéletesen kompakt réteget alkot). Ez a különbség még jobban kiemeli az anyag pórusos jellegét.

Annak érdekében, hogy bizonyítsuk, hogy a mért fotoáramok nem az esetlegesen a felszínre levált Pt hozzájárulásának köszönhetők (ellenelektródról való leoldódás és a munkaelektródra történő leválás eredményeként) [153], kicseréltük az ellenelektródot aranyra. Ezen mérés eredményeként elmondható, hogy az ellenelektród cseréje nem volt hatással a kapott fotoáram nagyságára.

Amennyiben a mintákat $0,1 \mathrm{~W} \mathrm{~cm}$ fényintenzitással világítottuk meg $0,69 \mathrm{~W} \mathrm{~cm}^{-2}$ helyett (annak érdekében, hogy a természetes napfény intenzitását imitáljuk), a fotoáram nagysága $\left(\mathrm{j}_{\text {foto }}=0,6 \mathrm{~mA} \mathrm{~cm}{ }^{-2}\right.$ ) lineárisan csökkent. A fotoáram értékek, amelyeket a különböző elektródokkal mértünk (ugyanabból a szintézisből azonos mennyiségü felfújt mennyiségek esetén) esetenként jelentősen eltérőek voltak, attól függően, hogy milyen hálózat alakult ki az elektród felszínén. 
Azért, hogy megvizsgáljuk a hőkezelés fotoelektrokémiai aktivitásra gyakorolt hatását, a $\mathrm{CuCrO}_{2}$ mintákat különböző hőmérsékleten hőkezeltük. A maximális fotoáram értéke $600{ }^{\circ} \mathrm{C}$-ig növekedett (54. ábra), majd ezt követően nem változott a hőkezelés hőmérsékletének további emelésével.
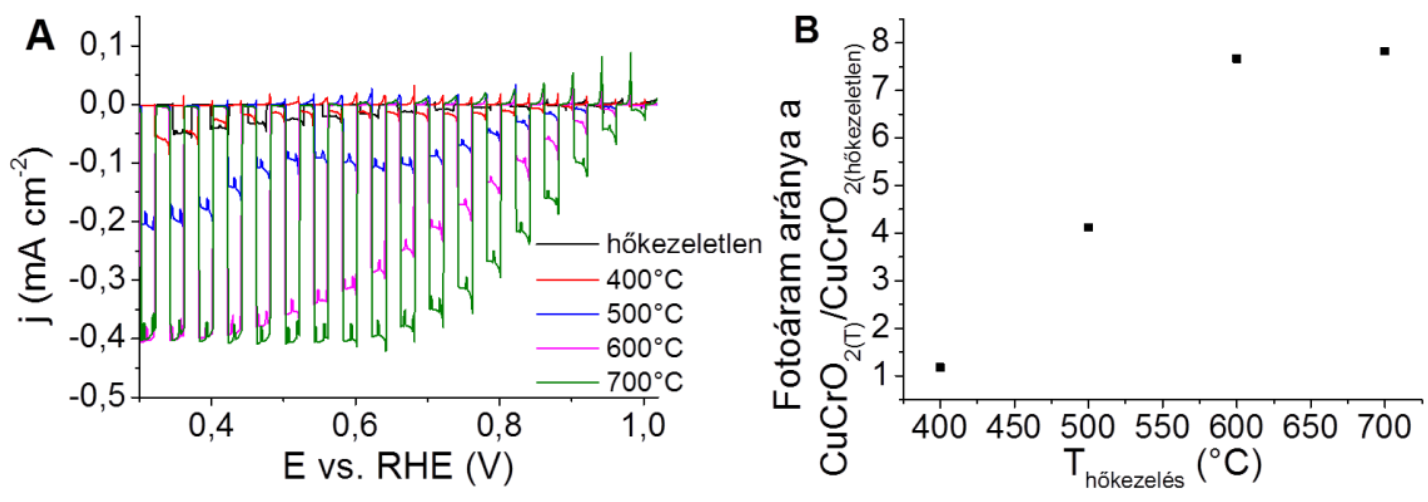

54. ábra: (A) A hőkezelés hatása az $0,5 \mathrm{~F} / \mathrm{O}$ aránynál szintetizált $\mathrm{CuCrO}_{2}$ lineáris fotovoltamogrammjaira, azonos felvitt tömeg esetén $\left(0,1 \mathrm{mg} \mathrm{cm}^{-2}\right), \mathrm{CO}_{2}$-al telített $0,1 \mathrm{M}$ $\mathrm{NaHCO}_{3}$ oldatban, $2 \mathrm{mV} \mathrm{s}^{-1}$ pásztázási sebesség és $0,1 \mathrm{~Hz}$ fényszaggatás mellett. (B) $\mathrm{A}$ hőkezelés hatása a fotoelektrokémiai aktivitásra. Az elektródokra optimálisan felvitt tömegeknél, a 0,4 V-nál mért fotoáramokat normalizáltuk a hökezeletlen $\mathrm{CuCrO}_{2} \mathrm{ra}$ mért fotoáram értékeivel azonos potenciálon.

Vizsgáltuk azoknak a mintáknak a fotoelektrokémiai aktivitását is, amelyeket levegőn hőkezeltünk, és föleg spinell szerkezetü $\mathrm{CuCr}_{2} \mathrm{O}_{4}$-böl és $\mathrm{CuO}$-ból álltak. Ezek a minták sokkal kisebb fotoáramokat mutattak, mint a $\mathrm{CuCrO}_{2}$ minták; mind UV-látható (55. ábra A), mind napfény szimulátor megvilágítás mellett (55. ábra B). Ezen minták esetén jelentős növekedés figyelhető meg továbbá a sötét áramban (0,2 V-tól kezdve), amely a $\mathrm{CuCrO}_{2}$-nál nem volt tapasztalható.

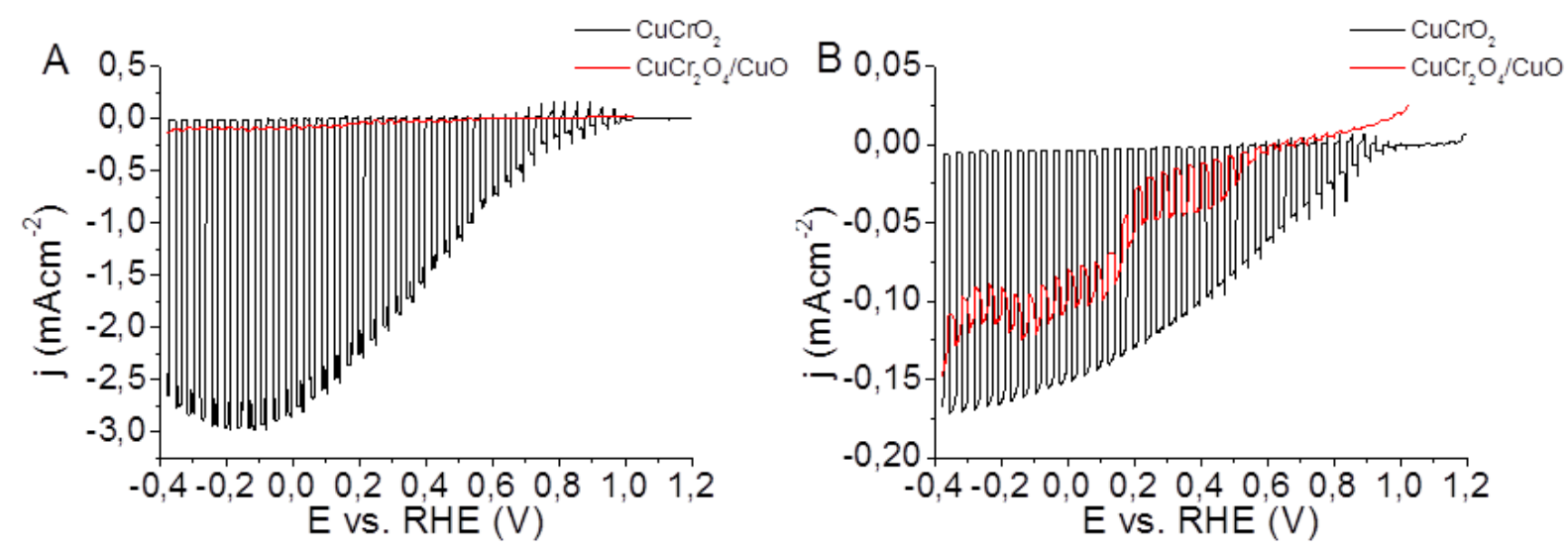

55. ábra: $0,5 \mathrm{~F} / \mathrm{O}$ aránynál szintetizált, $700{ }^{\circ} \mathrm{C}$-on 1 órán keresztül hökezelt $\mathrm{CuCrO}_{2}$ és a $\mathrm{CuCr}_{2} \mathrm{O}_{4} / \mathrm{CuO}$ fotoelektródok lineáris fotovoltamogrammjai, $2 \mathrm{mV} \mathrm{s}^{-1}$ pásztázási sebesség és $0,1 \mathrm{~Hz}$ fényszaggatás frekvenciája mellett, különböző fényforrásokat alkalmazva $\mathrm{CO}_{2}$-al telített $0,1 \mathrm{M} \mathrm{NaHCO}$ oldatban mérve. (A) $300 \mathrm{~W} \mathrm{Hg}$-Xe (UV) fényforrást, és (B) napfény szimulátort használva. 


\subsection{3. $\mathrm{A} \mathrm{CO}_{2}$ hosszú időtartamú fotoelektrolizise és termékek azonosítása}

Azért, hogy nyomon tudjuk követni a különböző $\mathrm{CO}_{2}$ redukciós termékek keletkezését és információt kapjunk a fotoelektród stabilitásáról, hosszú távú fotoelektrolízist végeztünk két különböző potenciálon ( 0,4 és $0,0 \mathrm{~V}$ vs. RHE). A megvilágító fényt periodikusan megszakítottuk annak érdekében, hogy megfigyelhessük az esetleges sötétáram megjelenését. Egyik esetben sem tapasztaltunk sötétáramot a mérés ideje alatt.

A negatívabb potenciálon végrehajtott fotoelektrolízis során a fotoáram értéke egy óra után jelentősen lecsökkent, amíg pozitívabb potenciálon a csökkenés sokkal lassabban következett be (56. ábra $\mathrm{A}, \mathrm{C})$. Mind két eseten a $\mathrm{CO}_{2}$ redukciós termékek, $\left(\mathrm{CO}\right.$ és $\left.\mathrm{CH}_{4}\right)$ valamint $\mathrm{H}_{2}$ voltak a gázfázisban (56. ábra $\mathrm{B}$, D), továbbá $\mathrm{HCOOH}$ és $\mathrm{CH}_{3} \mathrm{OH}$ a folyadékfázisban. A folyadékfázis összetételét NMR és GC-MS mérésekkel egyaránt megerősítettük. A redukciós termékek mennyisége lineárisan növekedett az áthaladt töltéssel, ami azt jelzi, hogy a vizsgált időintervallumban a lejátszódó folyamatok nem változtak.

A
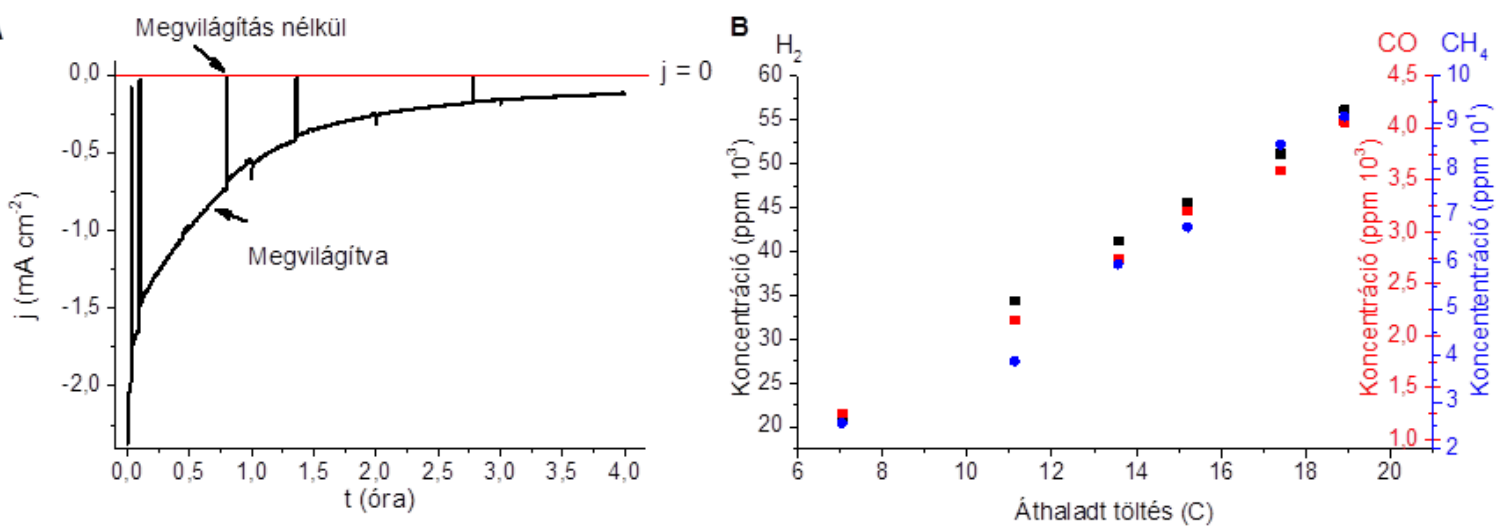

C
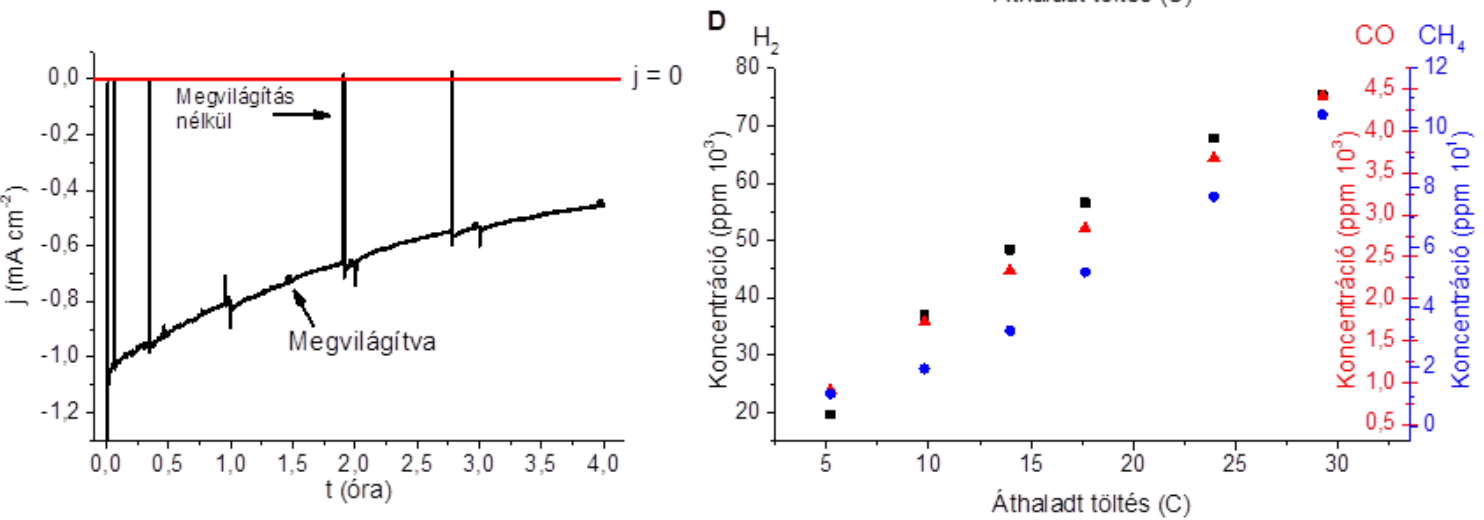

56. ábra: A $0,5 \mathrm{~F} / \mathrm{O}$ aránynál szintetizált, $700^{\circ} \mathrm{C}$-on 1 órán keresztül hőkezelt $\mathrm{CuCrO}_{2}$ kronoamperometriás görbéje, $\mathrm{CO}_{2}$-al telített $0,1 \mathrm{M} \mathrm{NaHCO}_{3}$ oldatban (A) $0,0 \mathrm{~V}$ és (C) és $0,4 \mathrm{~V}$ potenciálokon. A termékek koncentrációi a gázfázisban az áthaladt töltés függvényében (B) $0,0 \mathrm{~V}$ és (D) és $0,4 \mathrm{~V}$ potenciálokon. 
$\mathrm{Az}$ áthaladt töltés legnagyobb része mindkét esetben $\mathrm{H}_{2}$ fejlödésére fordítódott, ugyanakkor egy fontos különbség van a két potenciálon való elektrolízis között. A negatívabb potenciálon több $\mathrm{CO}, \mathrm{HCOOH}, \mathrm{CH}_{3} \mathrm{OH}$ és $\mathrm{CH}_{4}$ keletkezett (57 ábra). A teljes Faraday hatásfok minden esetben $85-90 \%$ volt, a többi töltés feltehetöen a $\mathrm{CuCrO}_{2}$ fotokorróziójára fordítódott, hasonlóan, mint a $\mathrm{Cu}_{2} \mathrm{O}$ esetében [34].

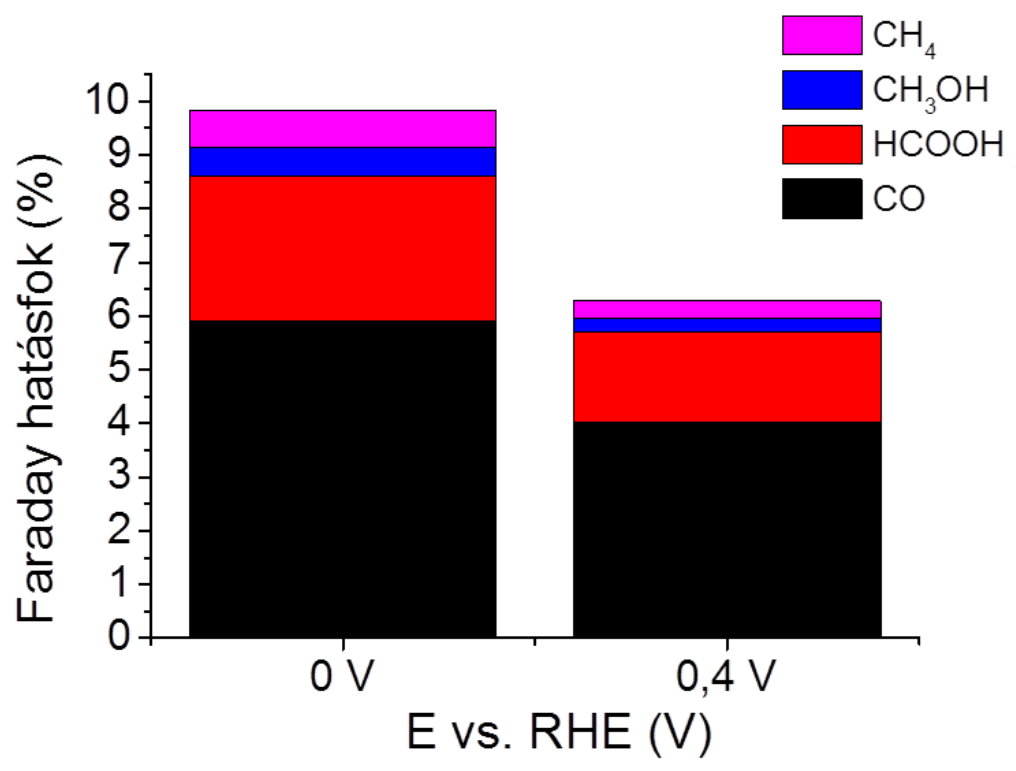

57. ábra: $\mathrm{A} \mathrm{CO}_{2}$ redukciós termékek Faraday hatásfoka 240 perc fotoelektrolízis után. A hosszútávú mérés során $\mathrm{CO}_{2}$-al telített $0,1 \mathrm{M} \mathrm{NaHCO}_{3}$ oldatot használtunk.

Hosszútávú méréseket végeztünk $\mathrm{N}_{2}$ atmoszférában is. Ezen mérések során nem volt más termék a fotoelektrolízis során, csak $\mathrm{H}_{2}$. Ez bizonyította, hogy a GC elektród a fotoelektrolízis során nem viselkedik szénforrásként. Amennyiben kicseréltük a munkaelektród anyagát rozsdamentes acélra, akkor azon mérések során a termékek azonosak voltak az üvegszén hordozó esetében mért termékekkel.

A méréseket megismételtük a $\mathrm{CO}_{2}$ gáz ${ }^{13} \mathrm{C}$ izotópjelzése mellett is. Az eredeti mérés során a $29 \mathrm{~m} / \mathrm{z}$ és $28 \mathrm{~m} / \mathrm{z}$ aránya 0,01 volt a CO-ban (58. Ábra A), ami jó egyezést mutat a levegőben mérhető természetes aránnyal. Amikor ${ }^{13} \mathrm{C}$-al jelzett $\mathrm{CO}_{2}$-ot használtunk a hosszú távú mérés során, akkor a $29 \mathrm{~m} / \mathrm{z}$ és a $28 \mathrm{~m} / \mathrm{z}$ aránya megváltozott 0,86 -ra a CO-ban (58. Ábra B). Ez a növekedés bizonyítja, hogy a termék a $\mathrm{CO}_{2}$ redukciós reakciójából származik és nem a $\mathrm{CuCrO}_{2}$ szennyeződéseiböl. Amennyiben a termékek a szennyeződések átalakulásából származott volna, akkor mind a két esetben azonos $29 \mathrm{~m} / \mathrm{z}$ és $28 \mathrm{~m} / \mathrm{z}$ arányt kellett volna tapasztalnunk. 

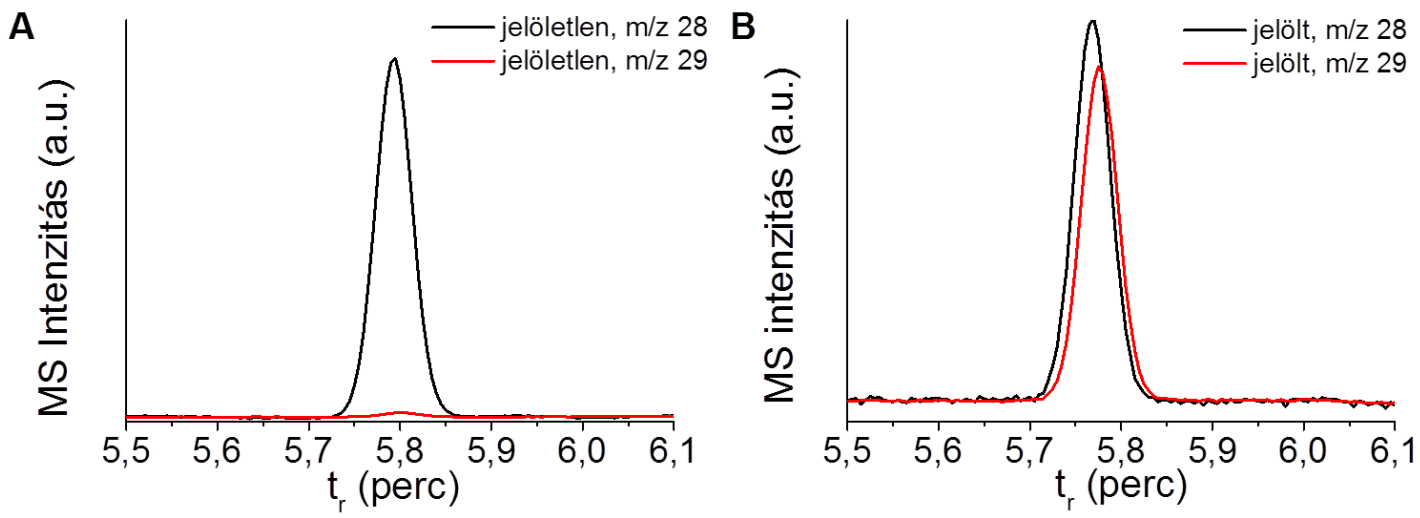

58. ábra: A 28 -as és a 29 -es $\mathrm{m} / \mathrm{z}$ molekula-ionok kromatogramjai a keletkezett szénmonoxid esetén ${ }^{12} \mathrm{CO}_{2}$ (A) és ${ }^{13} \mathrm{CO}_{2}$ (B)-t alkalmazva, a 240 perc fotoelektrolízist követően.

Összességében ezekkel a mérésekkel bizonyítottuk, hogy a $\mathrm{CuCrO}_{2}$ képes redukálni a $\mathrm{CO}_{2}$-t és a vizet, amelyre bizonyíték nem volt korábban a szakirodalomban. Az a tény, hogy képes volt egy $8 \mathrm{e}^{-}$redukcióra (pl. metán képződése) bizonyítja, hogy egy ígéretes fotoelektród alapanyag.

\section{3. $\mathrm{CuCr}_{\mathrm{x}} \mathrm{Fe}_{1-\mathrm{x}} \mathrm{O}_{2}$ ötvözet elektródok elöállítása és jellemzése}

\subsection{1. $\mathrm{CuFeO}_{2}, \mathrm{CuCr}_{\mathrm{x}} \mathrm{Fe}_{1-\mathrm{x}} \mathrm{O}_{2}$ ötvözetek elöállítása}

$\mathrm{A} \mathrm{CuFeO}_{2}$-ot és a $\mathrm{CuCr}_{\mathrm{x}} \mathrm{Fe}_{1-\mathrm{x}} \mathrm{O}_{2}$-ot hasonló módon állítottuk elő , mint a $\mathrm{CuCrO}_{2}$-ot . $\mathrm{A}$ referencia anyagként felhasznált $\mathrm{CuFeO}_{2}$ előállítása során annyi változtatást történt a 16-os egyenletben leírtakhoz képest, hogy a $\mathrm{Cr}\left(\mathrm{NO}_{3}\right)_{3}$ helyett $\mathrm{Fe}\left(\mathrm{NO}_{3}\right)_{3}$-ot használtunk. Erre azért volt lehetőség, mert feltehetően hasonló módon megy végbe a delafosszitok keletkezése [113,154]. Az ötvözetek elöállítása során a $\mathrm{Cr}\left(\mathrm{NO}_{3}\right)_{3}$ és $\mathrm{Fe}\left(\mathrm{NO}_{3}\right)_{3}$ arányát a kívánt összetételnek megfelelően választottuk meg. Erre egy példa a 25. egyenlet, mely a $\mathrm{CuCr}_{0,5} \mathrm{Fe}_{0,5} \mathrm{O}_{2}$ képződését mutatja be:

$$
\begin{aligned}
4,5 \mathrm{Fe}\left(\mathrm{NO}_{3}\right)_{3} & +4,5 \mathrm{Cr}\left(\mathrm{NO}_{3}\right)_{3}+9 \mathrm{Cu}\left(\mathrm{NO}_{3}\right)_{2}+26 \mathrm{C}_{2} \mathrm{H}_{5} \mathrm{NO}_{2} \\
& \rightarrow 9 \mathrm{CuCr}_{0,5} \mathrm{Fe}_{0,5} \mathrm{FeO}_{2}+52 \mathrm{CO}_{2}+65 \mathrm{H}_{2} \mathrm{O}+35,5 \mathrm{~N}_{2}
\end{aligned}
$$

Az elöállított termék nagy mennyiségü gázfejlödés mellett alakult ki exoterm reakció során, ennek köszönhetően nagy felületü, pórusos szerkezet várható. Ezen minta esetén is vizsgáltuk a F/O arány hatását az összetételre. A kémiailag közel tiszta terméket itt is a 0,5 F/O arány esetén értük el. Amíg kisebb arány esetén egy amorf fázis alakult ki, addig ennél nagyobb F/O arány esetén kristályos anyagot kaptunk. Ám nem delafosszit szerkezetü 
termék alakult ki, hanem kétfázisú kristályos $\mathrm{CuFe}_{2} \mathrm{O}_{4}$ (JCPDS\# 73-2315) és $\mathrm{CuCr}_{2} \mathrm{O}_{4}$ spinellek keletkeztek (59. ábra).

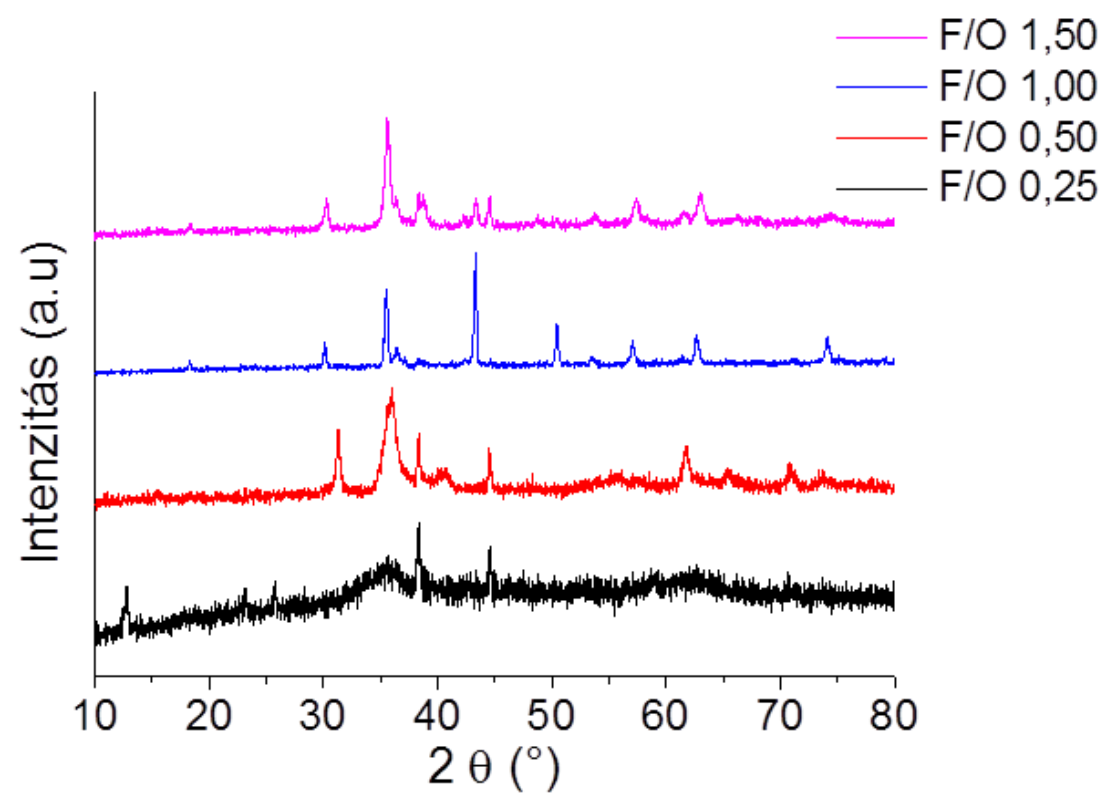

59. ábra: Különböző $\mathrm{F} / \mathrm{O}$ aránynál előállított, $\mathrm{Fe}$ és $\mathrm{Cr}$-t tartalmazó minták röntgendiffraktogramjai. A láthatóság kedvéért a görbék el lettek tolva egymástól.

\subsubsection{Szerkezeti jellemzés}

Azért, hogy megfigyelhessük a Fe beépülésének az optikai tulajdonságokra gyakorolt hatását, DR-UV-látható spektrumokat rögzítettünk (60. ábra A). Azáltal, hogy változtattuk az ötvözet összetételét (amelyet EDX mérésekkel erösítettünk meg), fokozatos vörös eltolódást lehetett megfigyelni a spektrumokon. Amikor kis mennyiségü vas épült be a tiszta $\mathrm{CuCrO}_{2}$-ba, az jelentősen változtatta a tiltottsáv-szélességet. A vas mennyiségének további növelése kismértékü változást okozott csak a tiltott sáv szélességében. Nagyobb vastartalomnál $(0,9<X<1,0)$ csak elhanyagolható nagyságú változás volt megfigyelhető (60. ábra B). 

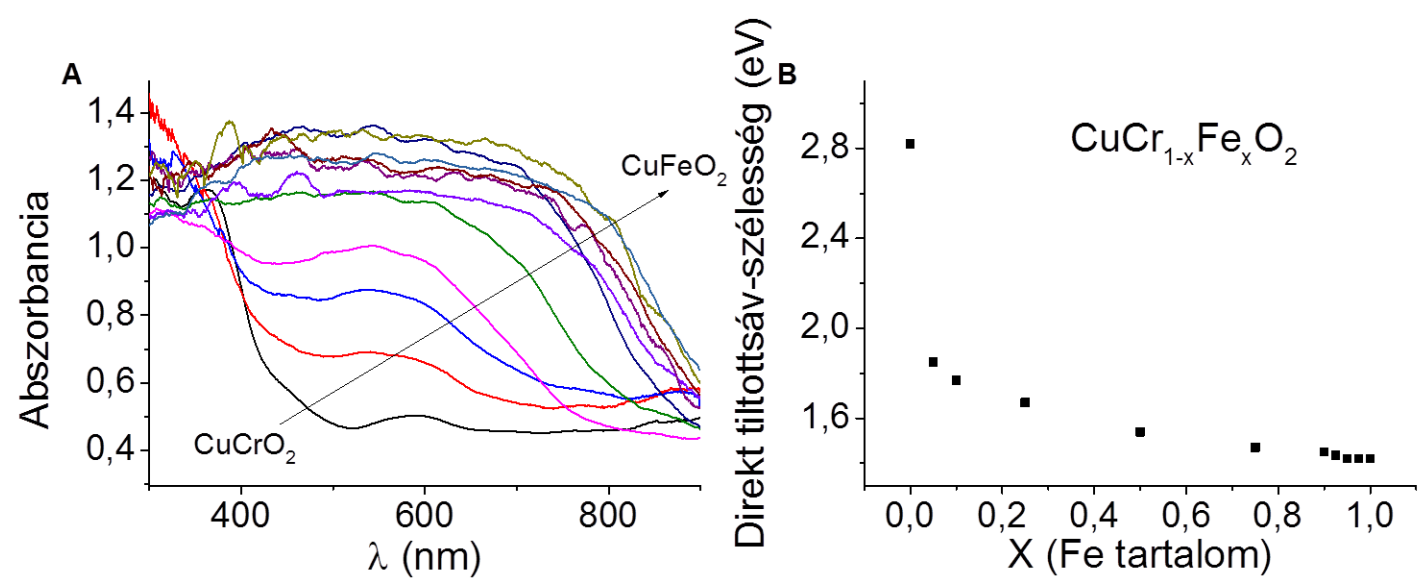

60. ábra: (A) $\mathrm{A} \mathrm{CuCr}_{1-\mathrm{x}} \mathrm{Fe}_{\mathrm{x}} \mathrm{O}_{2}$ ötvözetek UV-látható spektruma. (B) $\mathrm{A}$ direkt átmenethez tartozó tiltott-sávszélessége a különböző összetételü ötvözetek esetén (Tauc ábrázolásból meghatározva).

A vas beépülésének a delafosszitok kristályszerkezetére gyakorolt hatását XRD mérésekkel követtük nyomon. Fokozatos eltolódás volt tapasztalható a diffrakciók helyében; ez a tiszta $\mathrm{CuFeO}_{2}$-ra és $\mathrm{CuCrO}_{2}$-ra jellemző értékek között változott (61. ábra).

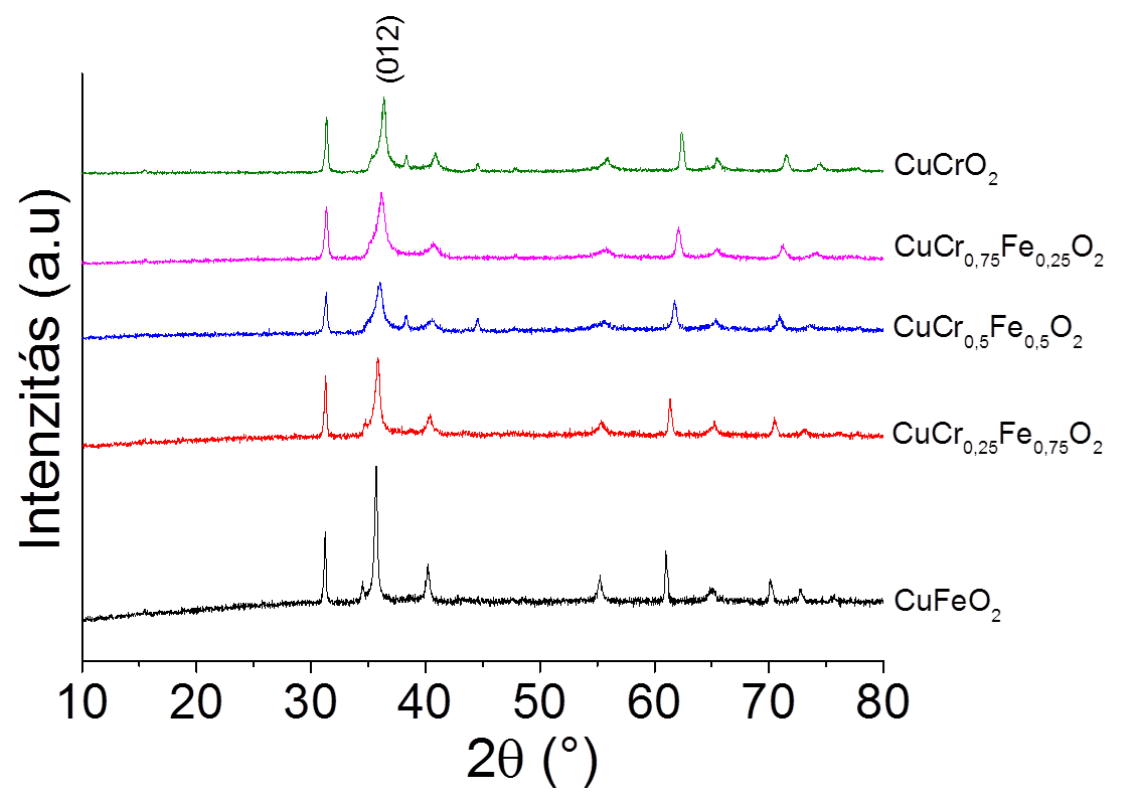

61. ábra: $\mathrm{A} \mathrm{CuCrO}, \mathrm{CuFeO}_{2}$ és ötvözeteinek röntgen diffraktrogrammja. A láthatóság kedvéért a görbék el lettek tolva egymástól.

A delafosszit elemi cella változásának jobb nyomonkövethetősége miatt, a (006) és (110) diffrakciókból meghatároztuk a kristálysík paramétereket (62. ábra). Azért választottuk ezt a két diffrakciót a számolásokhoz, mert a delafosszitok szerkezetéből adódóan a két rácsparaméter (a, b) azonos, így egy olyan reflexióból lehet kiszámolni, amely független a c paramétertől. A (110)-as reflexió ideális ehhez a számoláshoz mivel itt az a és a b paraméter ugyanolyan mértékben járul hozzá a reflexióhoz és a c paraméternek nincs hozzájárulása.. A számolt krisztallográfiai paraméterek lineárisan változtak a két 
tiszta anyagra kapott értékek között [155]. Ez jó egyezést mutat a Vegard-szabállyal [156], ami röviden azt jelenti, hogy amennyiben van két tiszta anyag, amelyeknek hasonló a rácstípusa, valamint a rácsállandói, akkor az ezekből alkotott elegykristályokban a rácsparaméterek az összetétellel lineárisan változnak. (62. ábra).

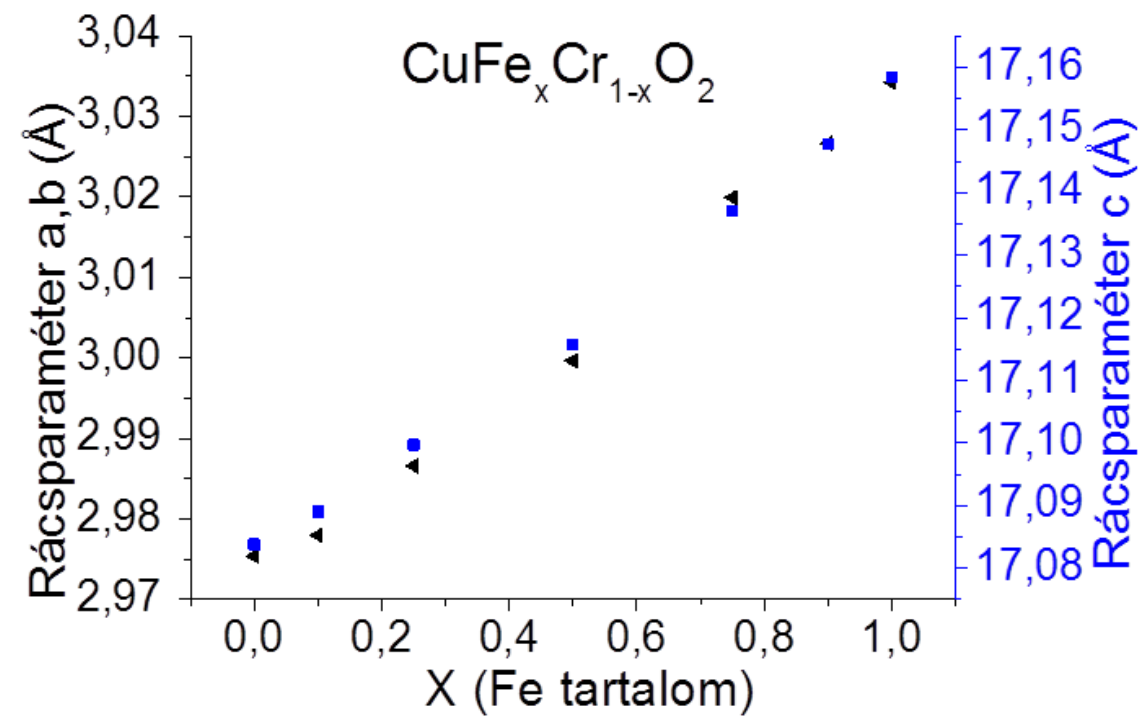

62. ábra: A rácsparaméterek változása az összetétel függvényében.

A $\mathrm{CuFeO}_{2}$ és az ötvözet morfológiájának vizsgálatához, SEM felvételeket készítettünk (63. ábra). Látható, hogy a $\mathrm{CuFeO}_{2}$-nak sokkal simább felszíne, valamint nem annyira porózus. Összekapcsolódott szerkezetet alkot, amely hasonló a $\mathrm{CuCrO}_{2}$-hoz. Ezen anyag esetén is elmondható, hogy apró részecskék szoros összekapcsolódásából épül fel. Az ötvözet esetén megfigyelhető, hogy hasonlóan másik két anyaghoz, kisebb részecskékből épül fel, valamint az összekapcsolódott szerkezet is megfigyelhető. Viszont összehasonlítva a $\mathrm{CuFeO}_{2}$-al, nagyobb porozitás figyelhető meg.
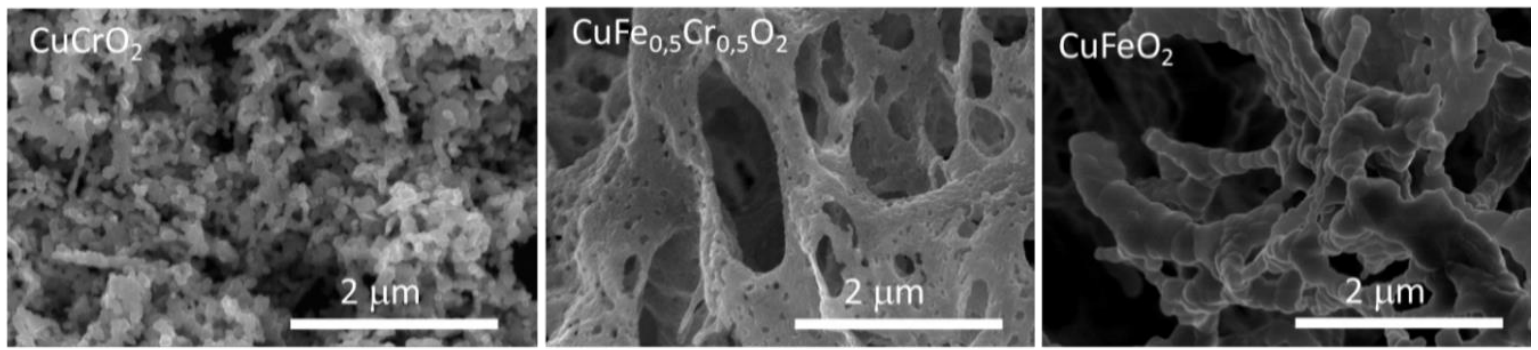

63. ábra: $\mathrm{A} \mathrm{CuCrO}_{2}$ és $\mathrm{CuFeO}_{2}$ és ötvözeteiknek a SEM képe. 


\subsubsection{Fotoelektrokémiai viselkedés}

Lineáris fotovoltammetria segítségével vizsgáltuk az anyagok fotoelektrokémiai aktivitását $\mathrm{CO}_{2}$-al telített $0,1 \mathrm{M} \mathrm{NaHCO} 3$ oldatokban. Fényforrásként minden esetben napfényszimulátort alkalmaztunk. Minden esetben a legnagyobb fotoáram értéket $1 \mathrm{mg} \mathrm{cm}^{-2}$ felvitt mennyiség esetén értük el. Az $\mathrm{E}=0,3 \mathrm{~V}$ vs. RHE potenciálon meghatározott fotoáram értékek lineárisan változtak az összetétellel (64. ábra).

Érdekesség, hogy a megnövekedett fényelnyelés nem tükrözi az előzőkben elmondott trendet. Egy nagymértékű növekedést vártunk a fotoáram értékekben kis mennyiségü vas beépülése során és kismértékü változást nagy vas tartalomnál (hasonlóan a tiltottsávszélesség változásához). Azonban a változás lineáris volt, amely azt mutatja, hogy az ötvöződés során az elektromos tulajdonságok változnak anyag összetételével.

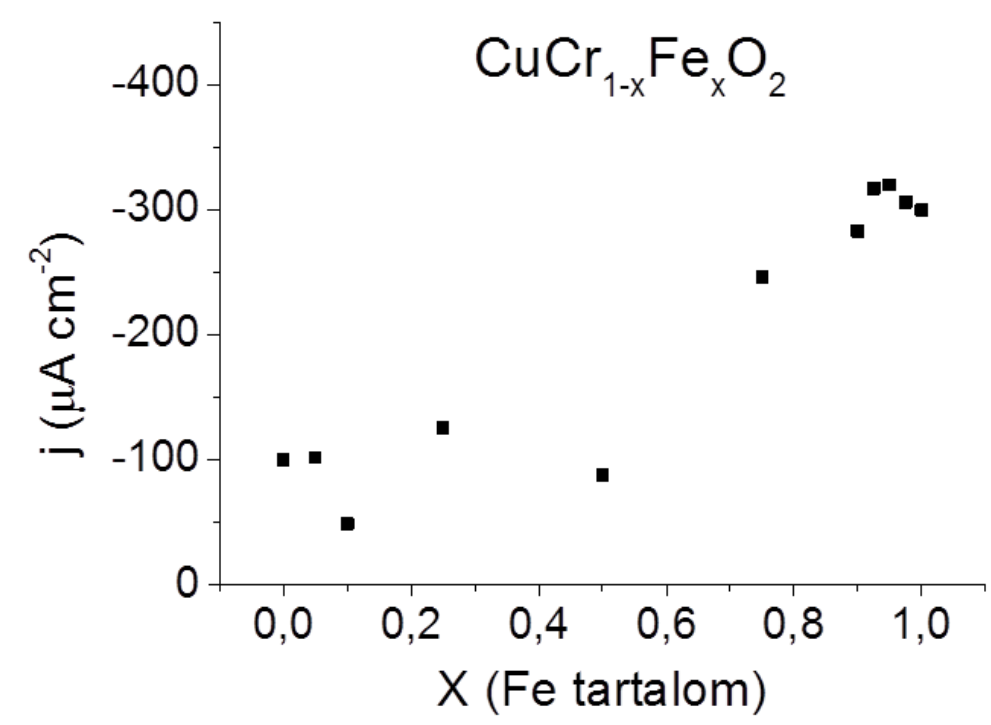

64. ábra: $\mathrm{A}$ különböző $\mathrm{CuCr}_{1-\mathrm{x}} \mathrm{Fe}_{\mathrm{x}} \mathrm{O}_{2}$ ötvözetek fotoáram értékei $1,0 \mathrm{mg} \mathrm{cm}{ }^{-2}$ elektródra felvitt tömeg esetén, napfény szimulátor fényforrást használva $(0,3 \mathrm{~V}$ potenciálon leolvasva).

\section{4. $\mathrm{CuCrO}_{2}$ és $\mathrm{CuFeO}_{2}$ kétfázisú elektródok előállítása és jellemzése}

\subsubsection{Szintézis}

Az összetett elektródok előállításának másik útja az, hogy nem az előzőekben bemutatott ötvözetet, hanem egy kétfázisú rendszert alakítunk ki a $\mathrm{CuCrO}_{2}$-ból és $\mathrm{CuFeO}_{2}$ ból. Amennyiben elérjük, hogy a keletkezett fázisok szoros kapcsolatban legyenek, akkor a két különböző anyagnak kihasználhatjuk az előnyös tulajdonságait, és nem kell számolnunk az előzőkben bemutatott elektromos változásokkal. 
Ahhoz, hogy a $\mathrm{CuCrO}_{2}$ és $\mathrm{CuFeO}_{2}$ kétfázisú rendszert elöállítsuk, különbözö üzemanyagokat igyekeztünk alkalmazni, például citromsavat és hexametiléntetramint (mint azt láthattuk glicinnel közvetlenül csak ötvözet alakítható ki egy lépésben). A szintézist követően ezekkel az üzemanyagokkal két lépésben előállíthatóak voltak a kétfázisú összetett oxidok. A $700{ }^{\circ} \mathrm{C}$-os $\mathrm{Ar}$ atmoszférában való hőkezelést követően azonban a kétfázisú rendszerekből egyfázisú rendszer alakult ki minden esetben.

Két típusú kompozitot állítottunk elö, egyik esetben a $\mathrm{CuCrO}_{2}$ hordozó felszínén választottunk le $\mathrm{CuFeO}_{2}$-t, ezt $\mathrm{CuFeO}_{2} / \mathrm{CuCrO}_{2}$-ként jelöltük. A második kompozit ennek fordítottja, a $\mathrm{CuCrO}_{2} / \mathrm{CuFeO}_{2}$. Mivel a kétfázisú rendszerek szintézisét nem lehet egy lépésben kivitelezni, két egymást követő oldatbelobbantásos szintézist hajtottunk végre. Az első lépésében a korábban ismertetett módon előállítottuk a hordozó összetett oxidot. A második lépésben a felszíni delafosszit előállításához szükséges reakcióelegy a megfelelő prekurzorokon kívül tartalmazta az első lépésben előállított hordozót is.

Különböző felszíni/hordozó delafosszit arányú kompozitokat állítottunk elő. Ehhez a második lépés során a hordozó állandó mennyisége mellett a felszíni összetett oxid kiindulási anyagainak mennyiségét változtattuk. Az így kapott elegyet az előmelegített főzőlapra helyezve hajtottuk végre a reakciót. A terméket mostuk, majd szárítószekrényben szárítottuk. Ezen kétfázisú anyagokból az ötvözeteknél ismertetett módon készítettünk elektródokat.

\subsubsection{Szerkezeti jellemzés}

Azért, hogy megvizsgáljuk az elkészített elektródok szerkezeti tulajdonságait, XRD méréseket végeztünk. Elmondható mind a $\mathrm{CuCrO}_{2} / \mathrm{CuFeO}_{2}$, mind a $\mathrm{CuFeO}_{2} / \mathrm{CuCrO}_{2}$ esetén, hogy ezzel a módszerrel sikerült kialakítani kétfázisú rendszert (65. ábra). Ezen rendszerek a hőkezelés hatására sem alakultak át ötvözetté. 

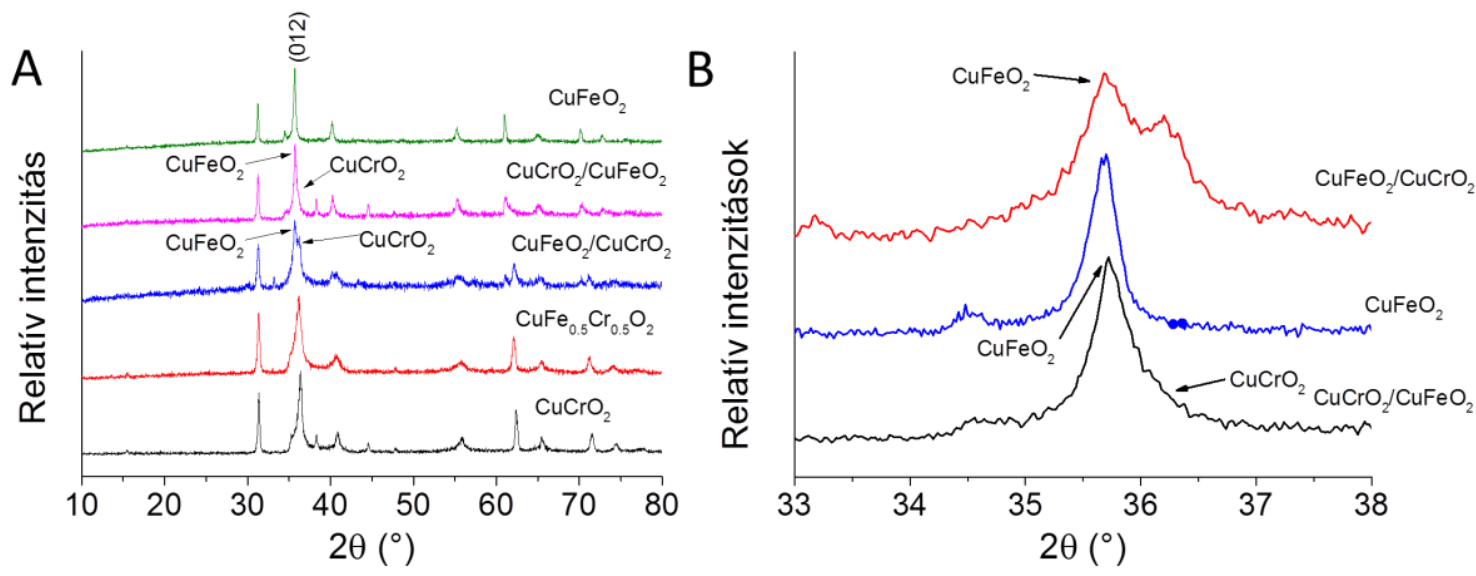

65. ábra: (A) $\mathrm{A}$ hökezelt $\mathrm{CuCrO}_{2}, \mathrm{CuFeO}_{2}$ és kétfázisú keverékeik röntgen diffraktogramjai; (B) A kétfázisú keverékek diffraktogramjai 33-38 $2 \theta$ közötti tartományon felnagyítva. A láthatóság kedvéért a görbék el lettek tolva egymástól.

A SEM felvételeken látható, hogy a különböző kétfázisú rendszereknél morfológiája nagymértékben különbözik. $\mathrm{A} \mathrm{CuCrO}_{2} / \mathrm{CuFeO}_{2}$ morfológiáját (66. ábra) úgy lehet jellemezni, hogy a $\mathrm{CuFeO}_{2}$ felszínét beburkolja a $\mathrm{CuCrO}_{2}$. Így a kapott struktúra képes átengedni a látható fényt, és az alsóbb réteg $\left(\mathrm{CuFeO}_{2}\right)$ képes ezt elnyelni. A másik kialakított szerkezet ennek a fordítottja (66. ábra), itt a $\mathrm{CuFeO}_{2}$ burkolja be a $\mathrm{CuCrO}_{2}-\mathrm{t}$. Ennél a szerkezetnél a fény nagy része a $\mathrm{CuFeO}_{2}$-ban nyelödik el, viszont az alatta lévő $\mathrm{CuCrO}_{2}$ elönyös a töltéshordozók gyors transzportjához. Ezt megerösítette az ezen anyagokra mért tiltottsáv-szélesség érték is, ahol minden esetben a burkoló delafosszit értékét tudtuk meghatározni. A kompozitok összetételét EDX-el vizsgálva elmondható, hogy minden esetben jó egyezést mutatott a tervezettel (a tervezett összetételtől a $\mathrm{Cr}$ : Fe arányban $\pm 1 \%$ volt az eltérés).
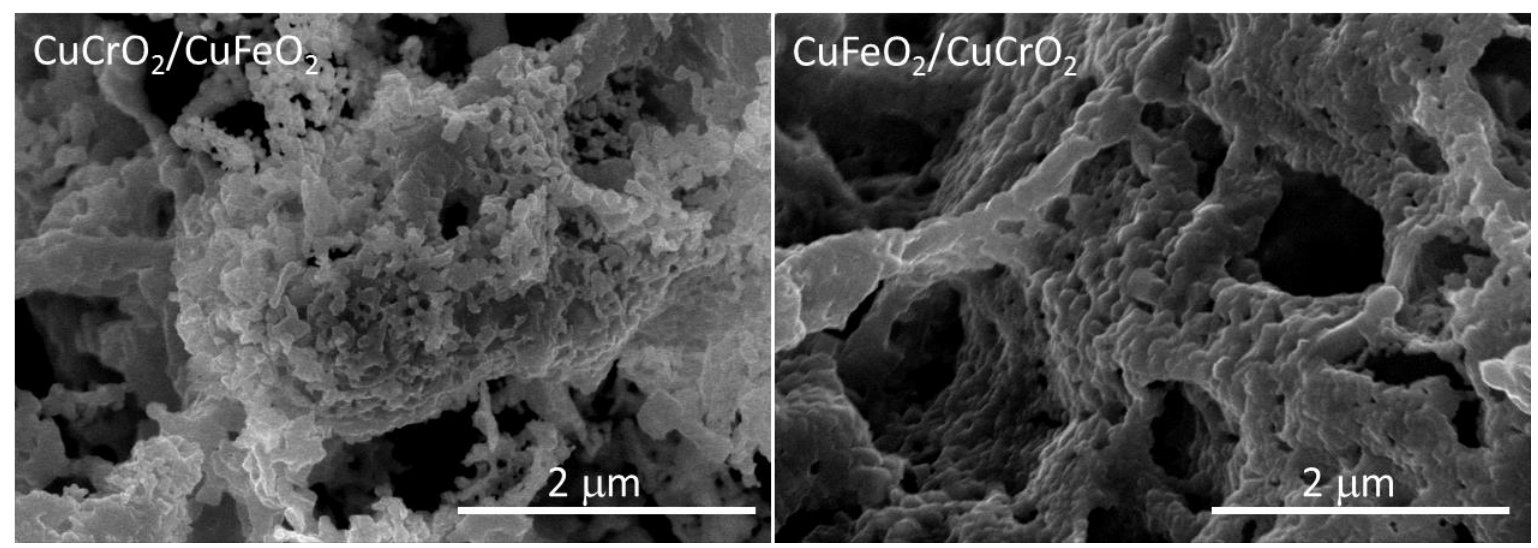

66. ábra $\mathrm{A}$ kétfázisú $\mathrm{CuCrO}_{2}$ és $\mathrm{CuFeO}_{2}$ minták SEM képei. 


\subsubsection{Fotoelektrokémiai tulajdonságok}

A kétfázisú oxidok fotoelektrokémiai aktivitásának jellemzésére lineáris fotovoltammetriás méréseket végeztünk, $\mathrm{CO}_{2}$-al telített $0,1 \mathrm{M} \mathrm{NaHCO}_{3}$-ban, valamint $\mathrm{N}_{2}$ el telített $0,1 \mathrm{M} \mathrm{Na} \mathrm{SO}_{4}$ oldatban, napfényszimulátor fényforrás használatával. Első lépésben referenciaként az oldatbelobbantásos eljárással készített $\mathrm{CuFeO}_{2}$ fotoelektrokémiai aktivitását vizsgáltuk (67. ábra). A voltammogrammokon jól látszik, hogy ebben az esetben is a $\mathrm{CO}_{2}$ jelenlétében nagyobb fotoáramokat mértünk, amely a $\mathrm{CO}_{2}$ redukciójához köthető.

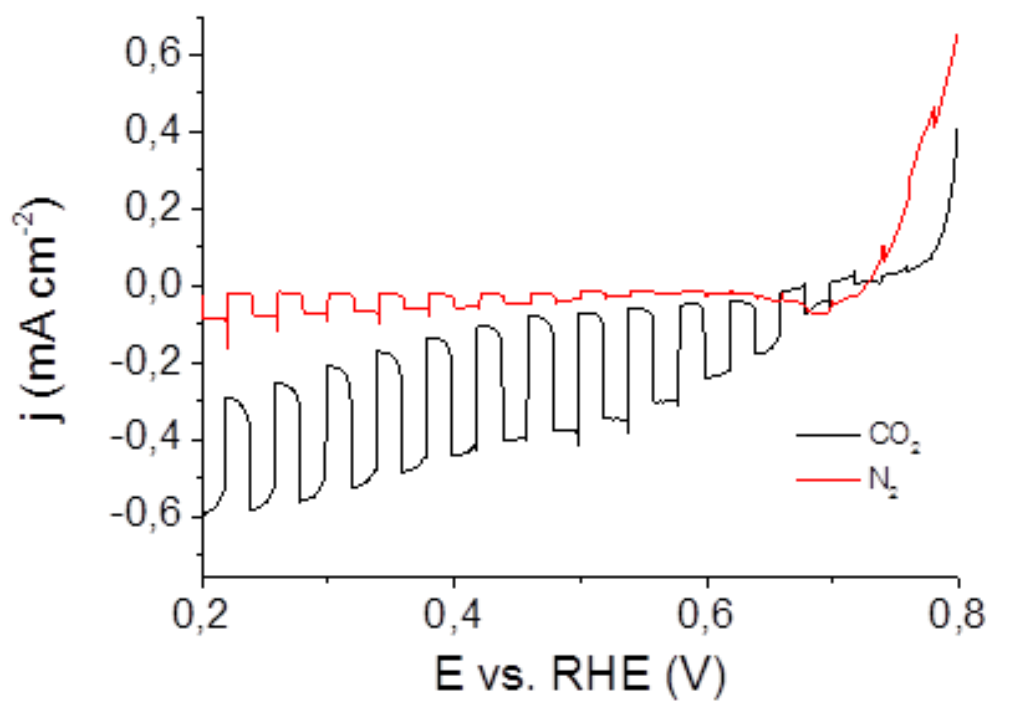

67. ábra: $\mathrm{CuFeO}_{2}$ lineáris fotovoltamogrammja $\mathrm{CO}_{2}$-al telített $0,1 \mathrm{M} \mathrm{NaHCO}$ valamint $\mathrm{N}_{2}$-el telített $0,1 \mathrm{M} \mathrm{Na}_{2} \mathrm{SO}_{4}$ oldatban, napfényszimulátor fényforrást használva, felületi borítottság $1 \mathrm{mg} \mathrm{cm}^{-1}$.

A $\mathrm{CuFeO}_{2}$ esetén a fotoredukciós folyamat megindulási potenciálja $0,75 \mathrm{~V}$-nál észlelhető, a fotoárama potenciál csökkenésével fokozatosan nő $\sim 0,5 \mathrm{~V}$-ig (68. ábra). A felületi mennyiség növelésével a fotoáram maximum-görbe szerint változott, az optimális felületi mennyiség $1 \mathrm{mg} \mathrm{cm}^{-2}$-nek adódott. A $0,3 \mathrm{~V}$ vs. RHE potenciál értéknél leolvasott maximális fotoáram nagysága $300 \mu \mathrm{A} \mathrm{cm} \mathrm{cm}^{-2}$ volt. Ez az érték hasonló a szakirodalomban közöltekhez [50]. 

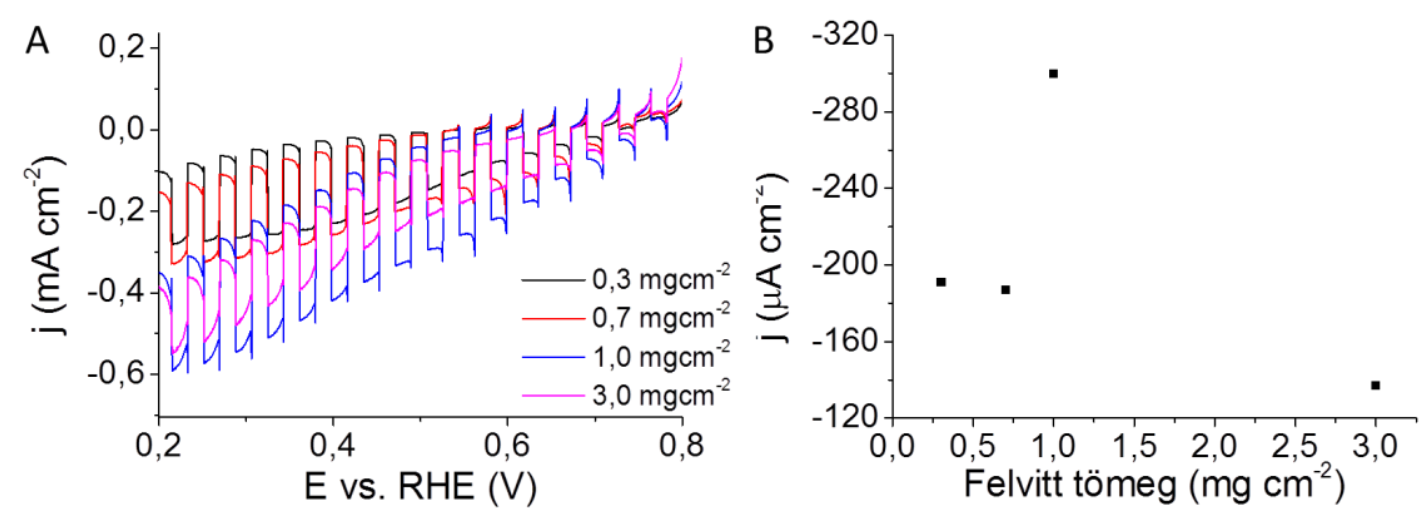

68. ábra (A) $\mathrm{A} \mathrm{CuFeO}_{2}$ lineáris fotovoltammogramja $0,1 \mathrm{M} \mathrm{NaHCO}_{3}$ oldatban, napfény szimulátor megvilágítása mellett, $(\mathrm{B}) \mathrm{E}=0,3 \mathrm{~V}$ potenciálon leolvasott fotoáramok nagysága különböző felvitt tömeg esetén.

Ezt követően, a különböző $\mathrm{CuFeO}_{2} / \mathrm{CuCrO}_{2}$ kompozitok fotoelektrokémiai viselkedését vizsgáltuk. A voltammogramok alakja hasonlóságot mutat a $\mathrm{CuFeO}_{2}$ voltammogramjához, azonban láthatóan a felületi mennyiség növekedésével nagyobb mértékben növekedett a sötét áram. A legnagyobb sötét áramot és fotoáramot minden esetben a $1 \mathrm{mg} \mathrm{cm}^{-2}$ felületi mennyiség esetén kaptuk (69. ábra). A felületi mennyiséget tovább növelve a sötét áramban, valamint a fotoáramban is csökkenést tapasztaltunk, amely feltehetően annak köszönhető, hogy a réteg olyan vastagságot ért el, hogy szigetelőként kezdett el viselkedni. A maximális fotoáram $\mathrm{j}_{\text {foto }}=-416 \mu \mathrm{A} \mathrm{cm}{ }^{-2}$ volt.
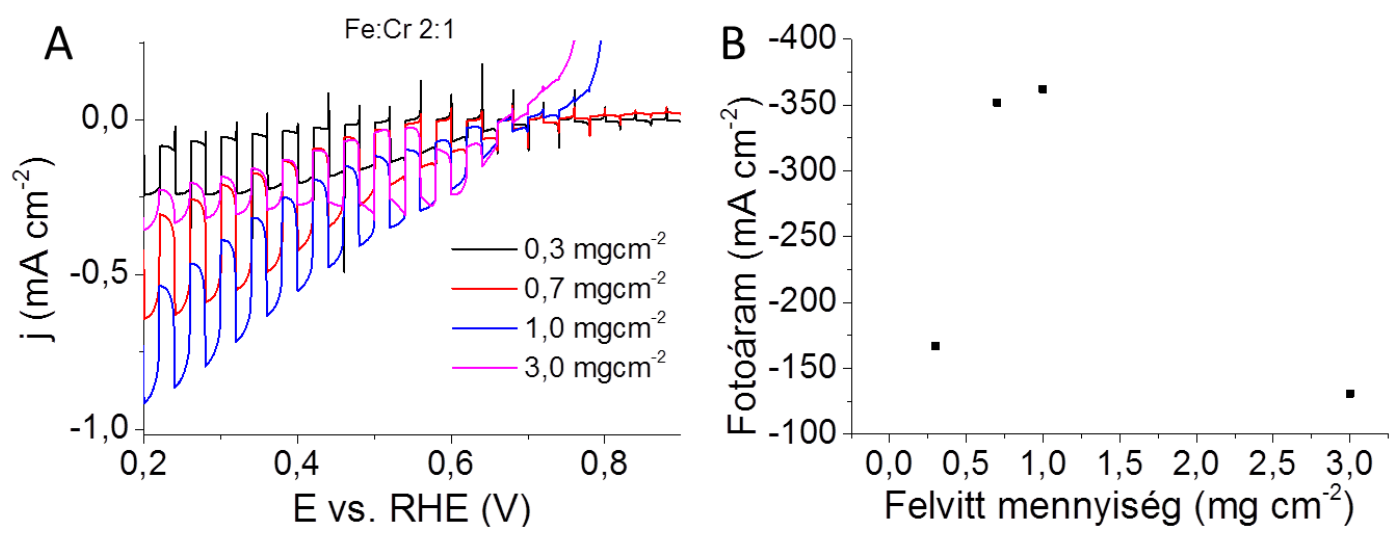

69. ábra: (A) $\mathrm{A} \mathrm{CuFeO}_{2} / \mathrm{CuCrO}_{2}$ lineáris fotovoltammogramja $0,1 \mathrm{M} \mathrm{NaHCO}$ oldatban napfény szimulátor megvilágítása mellett, $700{ }^{\circ} \mathrm{C}$-os $\mathrm{Ar}$ atmoszférában való hőkezelést követően, $2 \mathrm{mV} \mathrm{s}^{-1}$ pásztázási sebesség és $0,1 \mathrm{~Hz}$ fényszaggatás mellett, (B) $\mathrm{E}=$ $0,3 \mathrm{~V}$ potenciálon leolvasott fotoáramok nagysága különbözö felvitt tömeg esetén, napfény szimulátor fényforrást alkalmazva.

A maximálisan mért fotoáram értékeket ábrázolva a $\mathrm{CuFeO}_{2} / \mathrm{CuCrO}_{2}$ arány függvényében állandó $1 \mathrm{mg} \mathrm{cm}{ }^{-2}$ felületi borítottság mellett egy maximum görbe szerint változás figyelhető meg. A legnagyobb fotoáram értéket 1,33:1 $\mathrm{CuFeO}_{2} / \mathrm{CuCrO}_{2}$ arány 
esetében mértük (70. ábra). Az ekkor mért fotoáramsürüség nagyobb volt, mint amit a $\mathrm{CuCrO}_{2}$-ra vagy a $\mathrm{CuFeO}_{2}$-ra mértünk külön-külön. Ez azt mutatja, hogy a több Fe fontos az elnyelés szempontjából, viszont a $\mathrm{CuCrO}_{2}$ szerkezete elősegíti a jobb töltéstranszportot.

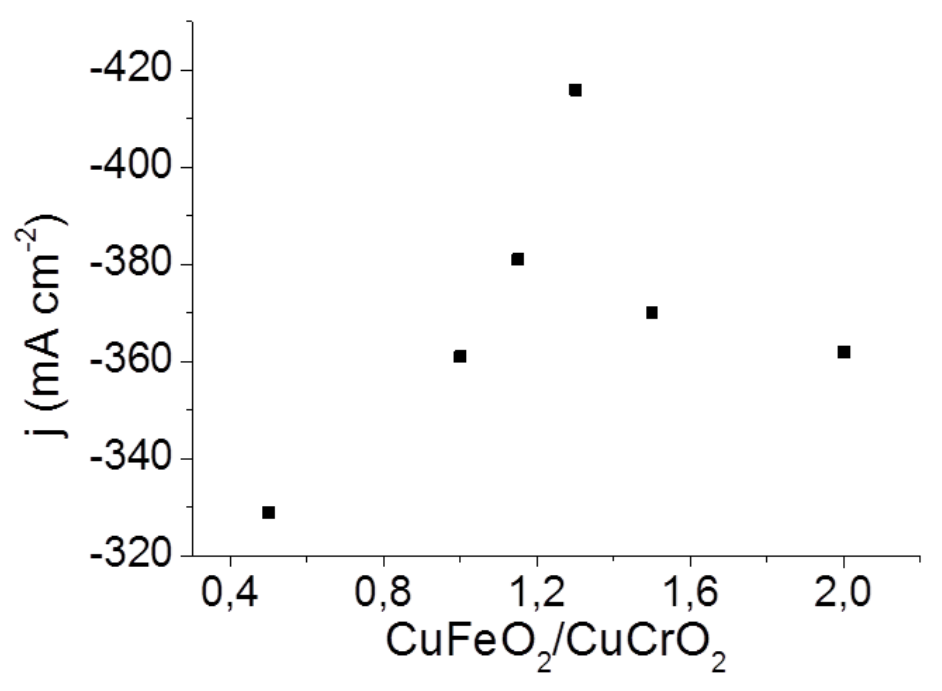

70. ábra: $\mathrm{A} \mathrm{CuFeO} / \mathrm{CuCrO}_{2}$ rendszer fotoáram értékei $\mathrm{CO}_{2}$-al telített $0,1 \mathrm{M} \mathrm{NaHCO}_{3}$ oldatban $\mathrm{E}=0,3 \mathrm{~V}$ vs. RHE potenciál értéknél leolvasva különbözö összetételeknél, napfény megvilágítás mellett, $700{ }^{\circ} \mathrm{C}$-os $\mathrm{Ar}$ atmoszférában való hökezelést követően $1 \mathrm{mg}$ $\mathrm{cm}^{-2}$ felületre felvitt mennyiség esetén.

Azon minták esetén is elvégeztük a fotoelektrokémiai jellemzést, amelyeknél a $\mathrm{CuFeO}_{2}$-t fedtük be a $\mathrm{CuCrO}_{2}$-al (71. ábra). Ezen minták esetén hasonló karakterisztikájú fotovoltamogrammokat kaptunk, mint előző esetben. A fotoáram valamint a sötét áram értékek hasonlóan növekedtek. Amennyiben a $0,3 \mathrm{~V}$ potenciálértéknél leolvasott fotoáramokat ábrázoljuk a felvitt mennyiség függvényében, akkor látható, hogy itt is $1 \mathrm{mg} \mathrm{cm}^{-2}$-nél érjük el a legnagyobb fotoelektrokémiai aktivitást.
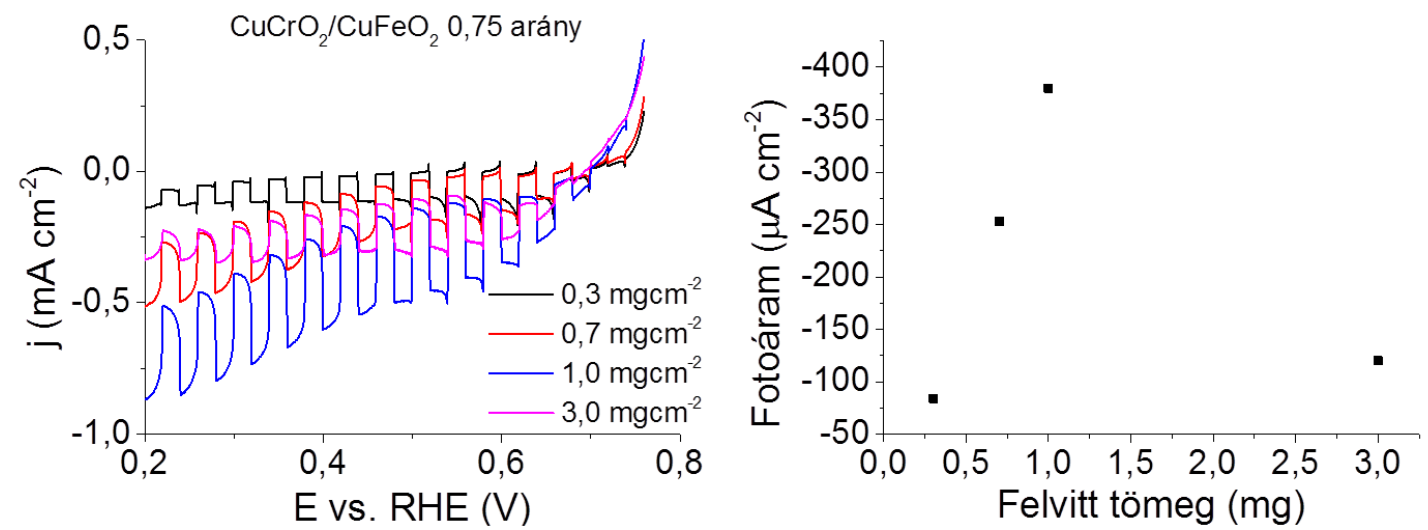

71. ábra: (A) $\mathrm{A} \mathrm{CuCrO}_{2} / \mathrm{CuFeO}_{2}$ lineáris fotovoltammogramja $0,1 \mathrm{M} \mathrm{NaHCO}_{3}$ oldatban napfény szimulátor megvilágítása mellett $700{ }^{\circ} \mathrm{C}$-os $\mathrm{Ar}$ atmoszférában való hökezelést követően, (B) $\mathrm{E}=0,3 \mathrm{~V}$ potenciálon leolvasott fotoáramok nagysága különbözö felvitt tömeg esetén. 
Amennyiben ábrázoljuk a $0,3 \mathrm{~V}$ potenciálon leolvasott fotoáram értékeket különböző arányoknál, akkor itt is egy maximum jellegü görbét kapunk (72. ábra). Ennek a maximuma 1,0 $\mathrm{CuCrO}_{2} / \mathrm{CuFeO}_{2}$ aránynál található. Ezt követően a fotoáram nagysága elkezd csökkeni.

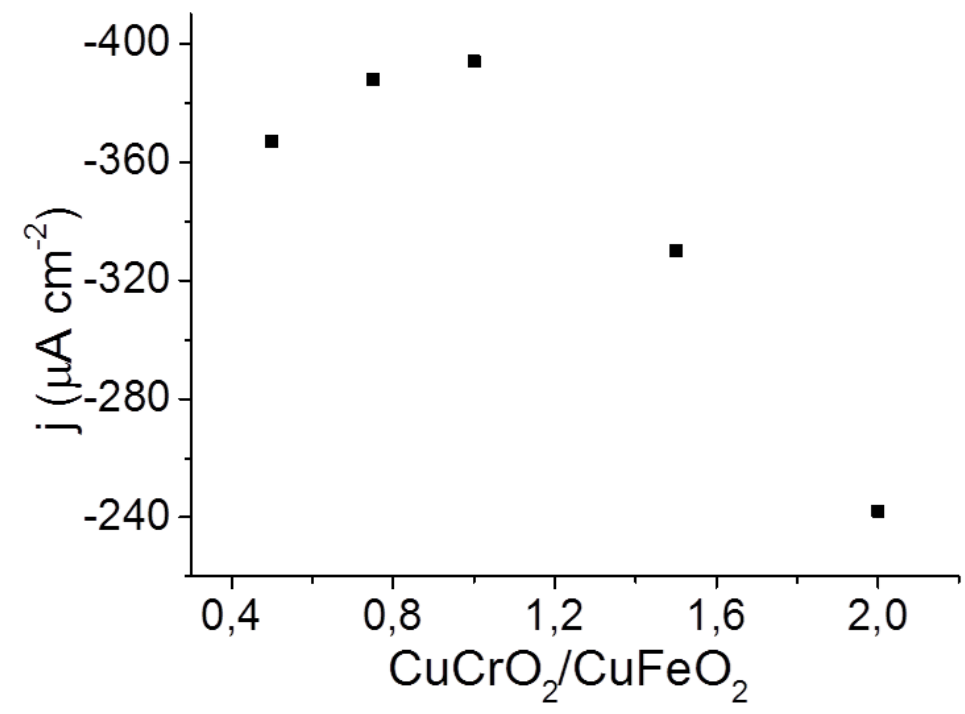

72. ábra: $\mathrm{A} \mathrm{CuCrO} \mathrm{Cu}_{2} / \mathrm{CuFeO}_{2}$ rendszer fotoáram értékei $\mathrm{CO}_{2}$-al telített $0,1 \mathrm{M} \mathrm{NaHCO}_{3}$ oldatban $\mathrm{E}=0,3 \mathrm{~V}$ vs. RHE potenciál értéknél leolvasva különböző összetételeknél, 700 ${ }^{\circ} \mathrm{C}$-os Ar atmoszférában való hőkezelést követően $1 \mathrm{mg} \mathrm{cm}^{-2}$ felületre felvitt mennyiség esetén, napfény szimulátor fényforrást alkalmazva. 


\section{6. Összefoglalás}

Munkám során p-típusú félvezető oxidokat készítettem különböző szintézismódszerekkel, amelyeken fotoelektrokémiai víz és szén-dioxid redukciós folyamatokat vizsgáltam. A félvezetőkön megvilágítás hatására végbemenő három fö folyamatot mindengyikének, a gerjesztésnek, töltéstranszportnak, ill. töltés-átlépésnek tanulmányozásával kívántuk a víz és a $\mathrm{CO}_{2}$ minél hatékonyabb átalakítását megvalósítani.

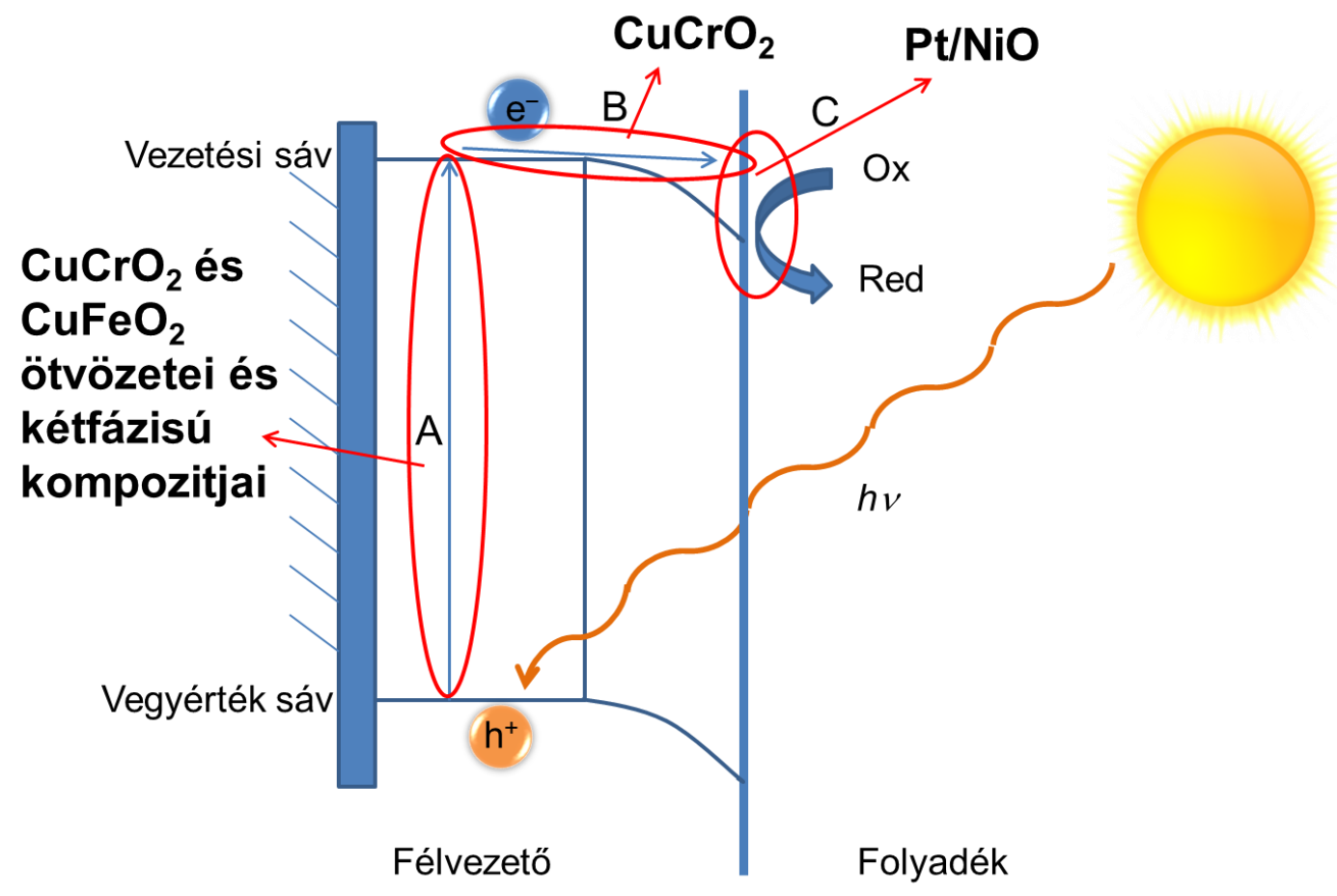

73. ábra $\mathrm{Az}$ elősegíteni kívánt, a fotokatódon megvilágítás hatására végbemenő folyamatok: (A) Fény elnyelése és elektron-lyuk szeparáció; (B) Töltéstranszport; (C) Töltésátlépés.

Pórusos $\mathrm{NiO}$ elektródokat állítottunk elő anodizáció segítségével. A szakirodalomban található anodizációs eljárásokat kívántuk adaptálni, azonban ezek nem vezettek sikerre. Ezért két eljárást kombinálva hoztuk létre a saját anodizációs módszerünket. A SEM felvételek alapján elmondható, hogy az elkészült rétegek pórusos szerkezettel rendelkeztek, és ezen pórusok átméröi a 10 - 20 nm-es mérettartományba estek. Vizsgáltuk továbbá a hőkezelés hatását a kialakított rétegeken, amelyek alapján azt a következtetést lehetett levonni, hogy az $500{ }^{\circ} \mathrm{C}$ feletti hőkezelés kristályos anyag keletkezéséhez vezet, amelynek hatására a mért fotoáramok is megnövekednek. Az előállított rétegeken mért fotoáram értékek jelentősen meghaladták a kompakt oxid, valamint $\mathrm{NiO}$ nanorészecskék rögzítésével kialakított fotoelektródok esetében mért értékeket. 
Annak érdekében, hogy megnöveljük a fotoelektrokémiai vízredukció során a töltésátlépés hatékonyságát, $\mathrm{Pt}$ nanorészecskéket vittünk fel a $\mathrm{NiO}$ rétegek felszínére. Ennek hatására a pórusok átmérői lecsökkentek a SEM képek alapján. A NiO és Pt közötti kapcsolatot TEM felvételek segítségével vizsgáltuk, amelyeken megfigyelhető, hogy a Pt nanorészecskék egyenletesen oszlanak el a NiO felszínén, és nem képeznek aggregátumokat. Az XPS mérések alapján elmondható, hogy a hökezelést követően a vizsgált mintákat főleg $\mathrm{NiO}$ alkotja, azonban további kisebbségi fázisok vannak jelen, mint például $\mathrm{NiOOH}$ és $\mathrm{Ni}(\mathrm{OH})_{2}$. Annak érdekében, hogy megvizsgáljuk anyagaink elektrokémiai viselkedését, azonos felületi Pt koncentrációk esetén ciklikus voltammogramokat vettünk fel a különböző Pt átmérővel készített kompozitokkal. Minden esetben nagyobb áramok haladtak át Pt mentes NiO-hoz képest a mérések során, amelyet a megnövekedett felülethez lehetett kötni. Ezzel összhangban lineáris fotovoltammetriás méréseket végeztünk, és ezen mérések során is minden esetben nagyobb fotoelektrokémiai aktivitás volt tapasztalható, mint a sima $\mathrm{NiO}$ esetén. IPCE mérések alapján elmondható volt, hogy a kompozit fényelnyelése nem változik a Pt felvitelének hatására. Impedancia spektroszkópiás méréseket végeztünk, amelyből származtatott Nyquist ábrákon megfigyelhető volt a töltésátlépési ellenállás csökkenése a Pt-val dekorált minták esetén a dekorálatlan mintákéhoz képest. Így ennek tudható be a jobb elektrokémiai viselkedés a tiszta NiO-hoz képest.

A Pt/NiO kompozitokat teszteltük víz redukciós folyamatokban. Minden esetben $\mathrm{H}_{2}$ fejlődést volt tapasztalható, és más gázt nem tudtunk detektálni a mérések során. A fejlödött $\mathrm{H}_{2}$ mennyisége arányosan nőtt az áthaladt töltéssel, és a Faraday hatásfok $70 \%$ volt.

$\mathrm{CuCrO}_{2}$ összetett oxidot állítottunk elő oldatbelobbantásos eljárással, melyet a fotoelektrokémiai $\mathrm{CO}_{2}$ redukciós folyamatban alkalmaztunk. A készített termékek a szintézist követően kristályosak voltak, valamint az összetételüket hangolni tudtuk a szintézisparaméterek változtatásával. Közel tiszta fázis anyagot állítottunk elő $0,5 \mathrm{~F} / \mathrm{O}$ arány alkalmazásával, amelyet IR és Raman-spektroszkópiával valamint röntgen diffraktometriával erősítettünk meg. Vizsgáltuk az utólagos hőkezelés hatását levegő, illetve Ar atmoszférában. A levegőn hőkezelt minták teljesen átalakultak spinell szerkezetű anyaggá, amíg az argonban kezelt minták esetén ilyen változást nem tapasztaltunk. Ezen mintáknál a kristályosság, valamint a fotoelektrokémiai aktivitás a hőkezelés hatására növekedett. 
A félvezető morfológiáját SEM képekkel jellemeztük, és azt tapasztaltuk, hogy a $\mathrm{CuCrO}_{2}$ pórusos szerkezettel rendelkezik. A TEM képeken megfigyelhető volt, hogy ez a pórusos szerkezet nanorészecskék (25-45 nm) szoros összekapcsolódásából áll össze. Annak érdekében, hogy meghatározzuk a tiltottsáv-szélességet, Tauc ábrázolást, valamint IPCE méréseket végeztünk. Mindkét módszerrel közel azonos $(2,83 ; 2,82 \mathrm{eV})$ tiltottsávszélességet kaptunk.

Fotoelektrokémiai mérések alapján elmondható, hogy $\mathrm{CO}_{2}$-dal telített oldatban nagyobb fotoelektrokémiai aktivitást mutat a félvezető, mint $\mathrm{N}_{2}$-el telített oldat esetén, amely a $\mathrm{CO}_{2}$-redukcióhoz köthető. Az alkotó egyfémes oxidokkal összehasonlítva a $\mathrm{CuCrO}_{2}$ elektródokon nagyobb fotoáramokat mértünk, valamint nagyobb stabilitás volt megfigyelhető a $\mathrm{Cu}_{2} \mathrm{O}$-hoz képest. Vizsgáltuk a fotoáram nagyságát a $\mathrm{CuCrO}_{2}$ felvitt mennyiségének függvényében és az optimális mennyiség $0,1 \mathrm{mg} \mathrm{cm}^{-2}$ adódott. Hosszú időtartamú mérésekkel bizonyítottuk, hogy a $\mathrm{CuCrO}_{2}$ képes a $\mathrm{CO}_{2}$-t fotoelektrokémiai úton redukálni. Termékekként minden mérés során $\mathrm{H}_{2}-\mathrm{t}, \mathrm{CO}-\mathrm{t}, \mathrm{CH}_{4}-\mathrm{t}$ tudtunk azonosítani a gázfázisból, és $\mathrm{HCOOH}-\mathrm{t}, \mathrm{CH}_{3} \mathrm{OH}-\mathrm{t}$ a folyadékfázisból. ${ }^{13} \mathrm{C}$ izotóppal jelzett $\mathrm{CO}_{2}$ segítségével bizonyítottuk, a keletkezett termékek valóban a $\mathrm{CO}_{2}$-redukciójából származnak.

Acélból, hogy a $\mathrm{CuCrO}_{2}$ minél nagyobb részét képes legyen elnyelni a látható fénynek, egy olyan anyaggal kombináltuk, amely kisebb tiltottsáv-szélességgel rendelkezik, valamint már bizonyítottan alkalmazták fotoelektrokémiai $\mathrm{CO}_{2}$ redukciós folyamatokban. Ehhez $\mathrm{CuCrO}_{2}$ és $\mathrm{CuFeO}_{2}$ ötvözeteit, valamint kétfázisú kompozitjaikat állítottuk elö.

Ehhez első lépésben referencia anyagként oldatbelobbantásos eljárással $\mathrm{CuFeO}_{2}-\mathrm{t}$ szintetizáltunk. A kapott anyagra mért fotoáram $-300 \mu \mathrm{A} \mathrm{cm}{ }^{-2}$, amely nagyságrendileg megegyezik a szakirodalomban található mért értékekkel. Ezt követően az ötvözeteket állítottuk elő úgy, hogy a $\mathrm{CuCrO}_{2}$ prekurzorait tartalmazó oldatban $\mathrm{Fe}\left(\mathrm{NO}_{3}\right)_{3}$-ot oldottunk fel. Különböző szerkezetvizsgáló módszerekkel, valamint UV látható spektrószkópiával is megvizsgáltuk az ötvözeteket. Röntgendiffrakciós vizsgálatok során az összetétel változtatásával párhuzamosan az egyes diffrakciók pozíciójában csúszás volt tapasztalható. Ez jó egyezést mutatott a Vegard szabállyal. A UV-látható spektroszkópiás mérések bizonyították, hogy a $\mathrm{Fe}$ beépülése a $\mathrm{CuCrO}_{2}$ szerkezetébe befolyásolta a tiltott sáv szélességét. A legnagyobb mértékü változást akkor tapasztaltuk, amikor csak kis mennyiségü Fe-t építettünk be a $\mathrm{CuCrO}_{2}$ szerkezetébe. $\mathrm{Az}$ ötvözetek esetén a SEM felvételek alapján elmondható, hogy az őket alkotó két delafosszit szerkezetének ötvözése tapasztalható, ebben az esetben is megfigyelhető a hálós szerkezet, csakúgy mint a tiszta 
$\mathrm{CuCrO}_{2}$ esetén. A fotoelektrokémai mérések azt bizonyították, hogy az ötvözetek rendelkeznek fotoaktívitással a látható hullámhosszúságú tartományban, és a mért fotoáramok a két tiszta anyag esetében meghatározott értékei közé estek.

Oldatbelobbantásos eljárással kétfázisú $\mathrm{CuCrO}_{2} / \mathrm{CuFeO}_{2}$ illetve $\mathrm{CuFeO}_{2} / \mathrm{CuCrO}_{2}$ oxidokat hoztunk létre, melyekben a fázisok egymással szoros kapcsolatban voltak. A röntgen diffraktogrammokon a $\mathrm{CuCrO}_{2}$-ra és $\mathrm{CuFeO}_{2}$-ra jellemző diffrakciók egymás mellett jelentek meg, amely bizonyította, hogy kétfázisú rendszer jött létre melyek hökezelés hatására se olvadnak egybe. A SEM felvételek alapján ezen anyagok morfológiája azt mutatta, hogy az egyik delafosszit teljesen beburkolja a másik anyagot. Ezt támasztják alá az UV-látható spektroszkópiás mérések, ahol csak egy delafosszit spektruma látszódik. A fotoelektrokémiai mérések bizonyították, hogy a kompozitoknak a látható fény hatására van fotoelektroémiai aktivitása. Ezen hibrideknél is a legnagyobb fotoelektrokémiai aktivitást $1 \mathrm{mg} \mathrm{cm}^{-2}$ felszíni borítottság mellett értük el. Mind a két kompozit esetén van olyan $\mathrm{CuFeO}_{2} / \mathrm{CuCrO}_{2}$ vagy $\mathrm{CuCrO}_{2} / \mathrm{CuFeO}_{2}$ arány, amelynél látható hullámhosszúságú fénnyel történő megvilágítás hatására a mért fotoáramok nagyobbak, mint az egyes alkotó delafosszitokra külön-külön. A maximális $-416 \mu \mathrm{A} \mathrm{cm}^{-2}$ fotoáramot a $\mathrm{CuFeO}_{2} / \mathrm{CuCrO}_{2}$ rendszernél értük el. 


\section{Summary}

In my work, I synthesized and characterized different p-type semiconductors and I tested them in photoelectrochemical water and $\mathrm{CO}_{2}$ reduction processes. To achieve the best efficiency, we wanted to enhance the main three processes occurring in the electrodes, the excitation, the transport and the transfer of the photoelectron.

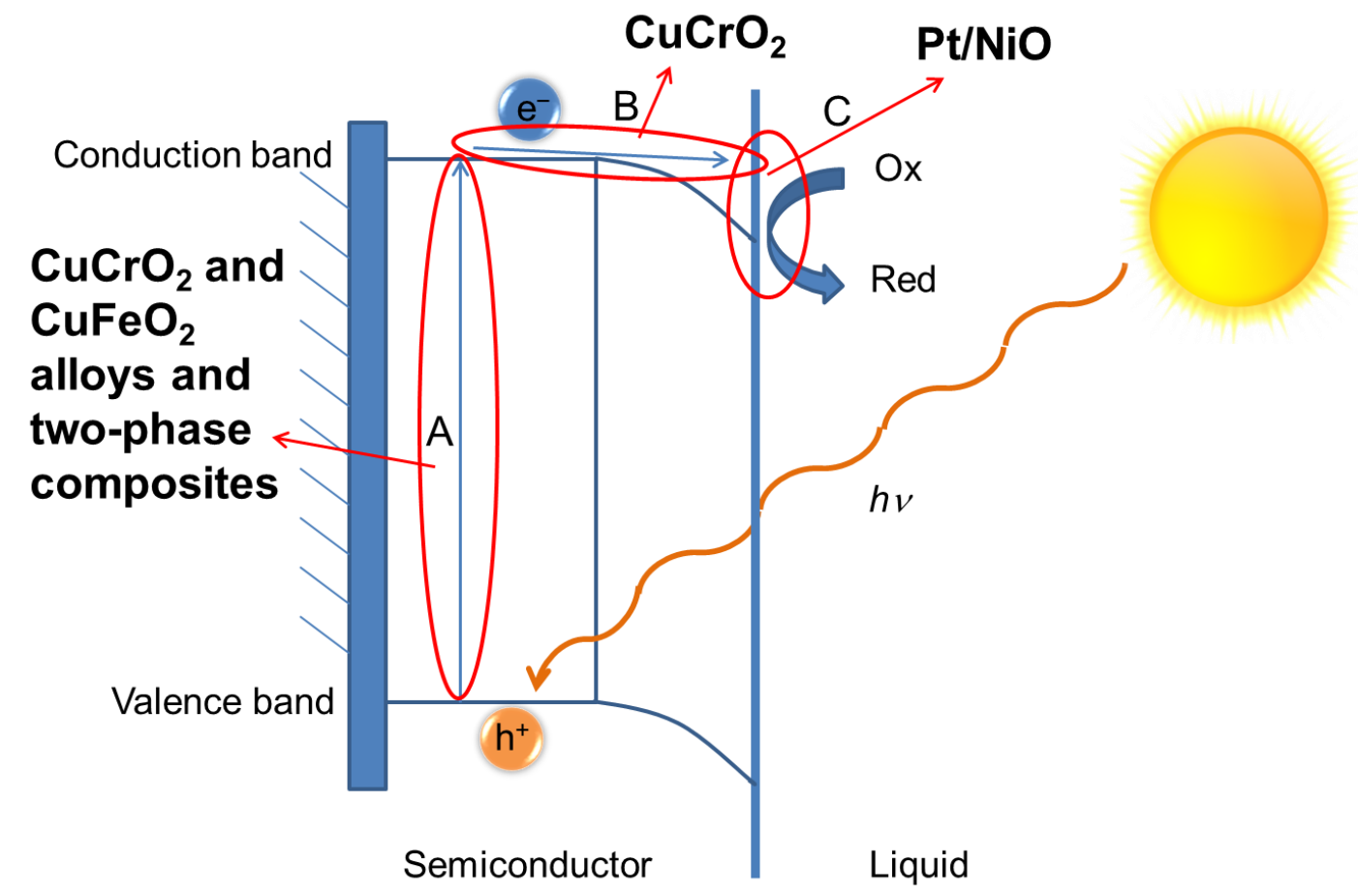

Figure 1. Different processes induced by illumination in photocathode which we wanted to enhance, (A) Light absorption and electron - hole separation; (B) Charge transport; (C) Charge transfer.

We synthesized porous $\mathrm{NiO}$ layers by anodization. We wanted to adopt the synthesis conditions from the literature, however the desired nanoporous and photoactive layer could not be achived by these methods. Therefore we developed a new method, with the combination of two previous ones. According to the SEM images, the NiO layers were porous and the diameters of the pores were between $10-20 \mathrm{~nm}$. We investigated the effect of heat treatment on the layers and we proved that crystalline semiconductor was formed above $500^{\circ} \mathrm{C}$, and consequently higher photocurrents were observed. Notably, higher photocurrent could be achived on the anodized sample compared to the compact oxid and on the nanopowder $\mathrm{NiO}$.

To increase the charge transfer efficiency during the photoelectrochemical water reduction, we decorated the bare $\mathrm{NiO}$ electrodes with $\mathrm{Pt}$ nanoparticles. According to the SEM images, the pore diameters decreased as an effect of the presence of Pt. We 
investigated the interaction between the $\mathrm{NiO}$ and the Pt by TEM. The TEM images showed that the Pt nanoparticles had a homogenous distribution on the surface of the $\mathrm{NiO}$ and there were no aggregates. According to the XPS measurments, after the heat treatment the main phase was NiO, however some minority phases could be observed, such as $\mathrm{NiOOH}$ and $\mathrm{Ni}(\mathrm{OH})_{2}$. To investigate the electrochemical behavior of the layers, we applied the same loading of Pt particles with different sizes during the cyclic voltammetry. In every measurement we observed higher photocurrents compared to the bare $\mathrm{NiO}$, which we could explain by the higher surface area. In accordance, linear sweep photovoltametry measurements were performed, and higher photoelectrochemical activity was observed than on the bare NiO. The IPCE measurements showed that that the absorbance of the composites did not change in a presence of the Pt. We also investigated the samples with electrochemical impedance spectroscopy, from the derived Nyquist plots, we observed the decrease of the charge transfer resistance in $\mathrm{Pt}$ loaded $\mathrm{NiO}$ layers. Thus, a better electrochemical behavior was achived on the Pt loaded $\mathrm{NiO}$ compared to the bare $\mathrm{NiO}$.

Finally, we tested the $\mathrm{Pt} / \mathrm{NiO}$ composites in photoelectrochemical water reduction. In all measurments $\mathrm{H}_{2}$ evolution was observed on the electrodes, and we could not detect any other product in the gas phase. The amount of the $\mathrm{H}_{2}$ linearly increased with the passed charge, and the faradaic efficiency was between $70 \%$ in every measurement.

We synthetized $\mathrm{CuCrO}_{2}$ by solution combustion synthesis, and it was used in photoelectrochemical $\mathrm{CO}_{2}$ reduction process. After the synthesis the product was crystalline. The composition of the product could be controlled by changing the synthesis parameters. Nearly phase pure semiconductor has been achieved at $0.5 \mathrm{~F} / \mathrm{O}$ ratio proved by IR and Raman spectroscopy and XRD measurments. We investigated the effect of post annealing on the materials in Ar or air atmosphere. The materials which was annealed in air atmostphere transformed into spinell structure, meanwhile in $\mathrm{Ar}$ atmosphere the structure did not changed. As an effect of increasing temperature of the annealing, the crystallinity and the photoelectrochemical performance increased.

The semiconductor morphology was investigated by SEM, and we could observe that the material has a porous structure. The TEM proved that, this porous structure buildup by interconnected nanoparticles $(25-45 \mathrm{~nm})$. To obtain the bandgap, Tauc plot was derived from UV-vis spectrocopy and IPCE measurments were performed. Nearly the same bandgaps $(2.83 ; 2.82 \mathrm{eV})$ were determined by both methods.

The linear photovoltammetry showed that $\mathrm{CuCrO}_{2}$ had higher photocurrents in $\mathrm{CO}_{2}$ saturated solution than in $\mathrm{N}_{2}$ saturated solution, as the result of $\mathrm{CO}_{2}$ reduction. The 
comparison of $\mathrm{CuCrO}_{2}$ and the monometallic counterparts proved that $\mathrm{CuCrO}_{2}$ had higher photocurrents and stability compared to the $\mathrm{Cu}_{2} \mathrm{O}$. We investigated the effect of the different loading on the photocurrent, and it was found that the optimal loading was $0.1 \mathrm{mg} \mathrm{cm}^{-2}$. We proved that the $\mathrm{CuCrO}_{2}$ capable to reduce the $\mathrm{CO}_{2}$ by long-term measurments. In every measurments we could detect $\mathrm{H}_{2}, \mathrm{CO}$ and $\mathrm{CH}_{4}$ in the gas phase and $\mathrm{HCOOH}$ and $\mathrm{CH}_{3} \mathrm{OH}$ in liquid phase. We proved that the product actually originated from the $\mathrm{CO}_{2}$ reduction by ${ }^{13} \mathrm{C}$ isotope labeling.

To increase the $\mathrm{CuCrO}_{2}$ absorbance in the visible light region, we combined with another delafossite which has smaller bandgap and it was already tested in photoelectrochemical $\mathrm{CO}_{2}$ reduction process. Therefore we synthetized alloys and twophase composites of $\mathrm{CuCrO}_{2}$ and $\mathrm{CuFeO}_{2}$.

In the first step we synthetized $\mathrm{CuFeO}_{2}$ as a reference by solution combustion. The maximum photocurrent of the synthetized $\mathrm{CuFeO}_{2}$ was $-300 \mu \mathrm{A} \mathrm{cm}^{-2}$ which was in good agreement with the literature. Then we synthetized the alloys by adding $\mathrm{Fe}\left(\mathrm{NO}_{3}\right)_{3}$ to the $\mathrm{CuCrO}_{2}$ precursor solution. XRD measurements showed that the change in the composition resulted in a shift on the diffractograms. This was in a good agreement with the Vegard's law. The UV-vis spectroscopy measurments proved the $\mathrm{Fe}$ incorporation into the $\mathrm{CuCrO}_{2}$ matrix and it changed the bandgap. The biggest change in the bandgap occurred when we added only a small amount of Fe into the matrix. The alloys morphology was investigated by SEM and we could observe that the two delafossite constituting parts were combined, and it had an interconnected sturcture. The photoelectrochemical measurements proved that alloys had a photoelectrochemical activity in the wavelength range of visible light, and the photocurrent values varying between the values of the two pure materials.

We synthetized two-phased $\mathrm{CuCrO}_{2} / \mathrm{CuFeO}_{2}$ and $\mathrm{CuFeO}_{2} / \mathrm{CuCrO}_{2}$ composites by solution combustion. The X-ray diffractogramms showed that the $\mathrm{CuCrO}_{2}$ and the $\mathrm{CuFeO}_{2}$ diffractions appear next to each other, which proved that the two phases formed, and these diffractions did not disappeared after annealing. According to the SEM images, one of the delafossite completely covered the other one. The UV-vis spectroscopy images proved that only the top delafossite could be observed. The best photoelectrochemical performance was achieved in a case of $1 \mathrm{mg} \mathrm{cm}^{-2}$ loading. There was an optimal ratio of the components in both composites where where we could measure higher photocurrents than to the constituting materials separately. The maximum value of the photocurrent was $-416 \mu \mathrm{A}$ $\mathrm{cm}^{-2}$ on the composites. 


\section{Hivatkozások}

[1] https://climate.nasa.gov/vital-signs/carbon-dioxide/. Utolsó megnyitás: 2019.02.15

[2] H. Frei, L. Berkeley, Front Matter, in: 2013: pp. P001-P004. doi:10.1039/9781849737739-FP001.

[3] C.A. Raines, The Calvin cycle revisited, Photosynth. Res. 75 (2003) 1-10. doi:10.1023/A:1022421515027.

[4] B. Kumar, M. Llorente, J. Froehlich, T. Dang, A. Sathrum, C.P. Kubiak, Photochemical and Photoelectrochemical Reduction of $\mathrm{CO}_{2}$, Annu. Rev. Phys. Chem. 63 (2012) 541-569. doi:10.1146/annurev-physchem-032511-143759.

[5] G. Centi, S. Perathoner, Opportunities and prospects in the chemical recycling of carbon dioxide to fuels, Catal. Today. 148 (2009) 191-205. doi:10.1016/j.cattod.2009.07.075.

[6] E. Lewis, N. S., Crabtree, G., Basic Research Needs for Solar Energy Utilization, Washington, DC, 2005.

[7] G.A. Olah, A. Goeppert, G.K.S. Prakash, Beyond Oil and Gas: The Methanol Economy: Second Edition, Beyond Oil Gas Methanol Econ. Second Ed. (2009) 1334. doi:10.1002/9783527627806.

[8] C.A. Raines, Photoelectrochemical Hydrogen Production, Springer US, Boston, MA, 2012. doi:10.1007/978-1-4614-1380-6.

[9] P.E. de Jongh, D. Vanmaekelbergh, J.J. Kelly, $\mathrm{Cu}_{2} \mathrm{O}$ : a catalyst for the photochemical decomposition of water?, Chem. Commun. (1999) 1069-1070. doi:10.1039/a901232j.

[10] W. Zhao, W. Fu, H. Yang, C. Tian, M. Li, Y. Li, L. Zhang, Y. Sui, X. Zhou, H. Chen, G. Zou, Electrodeposition of $\mathrm{Cu}_{2} \mathrm{O}$ films and their photoelectrochemical properties, CrystEngComm. 13 (2011) 2871. doi:10.1039/c0ce00829j.

[11] L. Junfu, C. Baozhu, Photoelectrochemical reduction of carbon dioxide on a $\mathrm{p}^{+} / \mathrm{p}-\mathrm{Si}$ photocathode in aqueous electrolyte, J. Electroanal. Chem. 324 (1992) 191-200. doi:10.1016/0022-0728(92)80045-6.

[12] M.S. Faber, M.A. Lukowski, Q. Ding, N.S. Kaiser, S. Jin, Earth-Abundant Metal Pyrites $\left(\mathrm{FeS}_{2}, \mathrm{CoS}_{2}, \mathrm{NiS}_{2}\right.$, and Their Alloys) for Highly Efficient Hydrogen Evolution and Polysulfide Reduction Electrocatalysis, J. Phys. Chem. C. 118 (2014) 21347-21356. doi:10.1021/jp506288w.

[13] M.H. Lee, K. Takei, J. Zhang, R. Kapadia, M. Zheng, Y.-Z. Chen, J. Nah, T.S. Matthews, Y.-L. Chueh, J.W. Ager, A. Javey, p-Type InP Nanopillar Photocathodes for Efficient Solar-Driven Hydrogen Production, Angew. Chemie Int. Ed. 51 (2012) 10760-10764. doi:10.1002/anie.201203174. 
[14] X. Chang, T. Wang, P. Zhang, Y. Wei, J. Zhao, J. Gong, Stable Aqueous Photoelectrochemical $\mathrm{CO}_{2}$ Reduction by a $\mathrm{Cu}_{2} \mathrm{O}$ Dark Cathode with Improved Selectivity for Carbonaceous Products, Angew. Chemie Int. Ed. 55 (2016) 88408845. doi:10.1002/anie.201602973.

[15] Q. Zhai, S. Xie, W. Fan, Q. Zhang, Y. Wang, W. Deng, Y. Wang, Photocatalytic Conversion of Carbon Dioxide with Water into Methane: Platinum and Copper(I) Oxide Co-catalysts with a Core-Shell Structure, Angew. Chemie Int. Ed. 52 (2013) 5776-5779. doi:10.1002/anie.201301473.

[16] I. Sullivan, B. Zoellner, P.A. Maggard, Copper(I)-Based p -Type Oxides for Photoelectrochemical and Photovoltaic Solar Energy Conversion, Chem. Mater. 28 (2016) 5999-6016. doi:10.1021/acs.chemmater.6b00926.

[17] E. Kecsenovity, B. Endrődi, Z. Pápa, K. Hernádi, K. Rajeshwar, C. Janáky, Decoration of ultra-long carbon nanotubes with $\mathrm{Cu}_{2} \mathrm{O}$ nanocrystals: a hybrid platform for enhanced photoelectrochemical $\mathrm{CO}_{2}$ reduction, J. Mater. Chem. A. 4 (2016) 3139-3147. doi:10.1039/C5TA10457B.

[18] H.-L. Wu, X.-B. Li, C.-H. Tung, L.-Z. Wu, Recent Advances in Sensitized Photocathodes: From Molecular Dyes to Semiconducting Quantum Dots, Adv. Sci. 136 (2018) 1700684. doi:10.1002/advs.201700684.

[19] A.J. Bard, L.R. Faulkner, E. Swain, C. Robey, Fundamentals and Applications, 2nd Edition (2000)

[20] J.L. White, M.F. Baruch, J.E. Pander III, Y. Hu, I.C. Fortmeyer, J.E. Park, T. Zhang, K. Liao, J. Gu, Y. Yan, T.W. Shaw, E. Abelev, A.B. Bocarsly, Light-Driven Heterogeneous Reduction of Carbon Dioxide: Photocatalysts and Photoelectrodes, Chem. Rev. 115 (2015) 12888-12935. doi:10.1021/acs.chemrev.5b00370.

[21] M.G. Walter, E.L. Warren, J.R. McKone, S.W. Boettcher, Q. Mi, E.A. Santori, N.S. Lewis, Solar Water Splitting Cells, Chem. Rev. 110 (2010) 6446-6473. doi:10.1021/cr1002326.

[22] L.L. Snuffin, L.W. Whaley, L. Yu, Catalytic Electrochemical Reduction of $\mathrm{CO}_{2}$ in Ionic Liquid EMIMBF${ }_{3} \mathrm{Cl}$, J. Electrochem. Soc. 158 (2011) F155. doi:10.1149/1.3606487.

[23] K. Hirota, D.A. Tryk, T. Yamamoto, K. Hashimoto, M. Okawa, A. Fujishima, Photoelectrochemical Reduction of $\mathrm{CO}_{2}$ in a High-Pressure $\mathrm{CO}_{2}+$ Methanol Medium at p-Type Semiconductor Electrodes, J. Phys. Chem. B. 102 (1998) 98349843. doi:10.1021/jp9822945.

[24] L. Zhang, Z.-J. Zhao, J. Gong, Nanostructured Materials for Heterogeneous Electrocatalytic $\mathrm{CO}_{2}$ Reduction and their Related Reaction Mechanisms, Angew. Chemie Int. Ed. 56 (2017) 11326-11353. doi:10.1002/anie.201612214.

[25] J. Yu, J.C. Yu, W. Ho, Z. Jiang, Effects of calcination temperature on the photocatalytic activity and photo-induced super-hydrophilicity of mesoporous $\mathrm{TiO}_{2}$ thin films, New J. Chem. 26 (2002) 607-613. doi:10.1039/b200964a. 
[26] K. Sivula, F. Le Formal, M. Grätzel, Solar water splitting: Progress using hematite $\left(\alpha-\mathrm{Fe}_{2} \mathrm{O}_{3}\right) \quad$ photoelectrodes, ChemSusChem. 4 (2011) 432-449. doi:10.1002/cssc. 201000416 .

[27] M. Heinemann, B. Eifert, C. Heiliger, Band structure and phase stability of the copper oxides $\mathrm{Cu}_{2} \mathrm{O}, \mathrm{CuO}$, and $\mathrm{Cu}_{4} \mathrm{O}_{3}$, Phys. Rev. B. 87 (2013) 115111. doi:10.1103/PhysRevB.87.115111.

[28] J. Li, F. Meng, S. Suri, W. Ding, F. Huang, N. Wu, Photoelectrochemical performance enhanced by a nickel oxide-hematite $\mathrm{p}-\mathrm{n}$ junction photoanode, Chem. Commun. 48 (2012) 8213. doi:10.1039/c2cc30376k.

[29] J.C. Hill, K.-S. Choi, Synthesis and characterization of high surface area $\mathrm{CuWO}_{4}$ and $\mathrm{Bi}_{2} \mathrm{WO}_{6}$ electrodes for use as photoanodes for solar water oxidation, J. Mater. Chem. A. 1 (2013) 5006. doi:10.1039/c3ta10245a.

[30] Q. Hua, T. Cao, X.-K. Gu, J. Lu, Z. Jiang, X. Pan, L. Luo, W.-X. Li, W. Huang, Crystal-Plane-Controlled Selectivity of $\mathrm{Cu}_{2} \mathrm{O}$ Catalysts in Propylene Oxidation with Molecular Oxygen, Angew. Chemie Int. Ed. 53 (2014) 4856-4861. doi:10.1002/anie.201402374.

[31] Y.-K. Hsu, C.-H. Yu, Y.-C. Chen, Y.-G. Lin, Synthesis of novel $\mathrm{Cu}_{2} \mathrm{O}$ micro/nanostructural photocathode for solar water splitting, Electrochim. Acta. 105 (2013) 62-68. doi:10.1016/j.electacta.2013.05.003.

[32] Y.-K. Hsu, J.-R. Wu, M.-H. Chen, Y.-C. Chen, Y.-G. Lin, Fabrication of homojunction $\mathrm{Cu}_{2} \mathrm{O}$ solar cells by electrochemical deposition, Appl. Surf. Sci. 354 (2015) 8-13. doi:10.1016/j.apsusc.2015.05.142.

[33] K.E.R. Brown, K.-S. Choi, Electrochemical synthesis and characterization of transparent nanocrystalline $\mathrm{Cu}_{2} \mathrm{O}$ films and their conversion to $\mathrm{CuO}$ films., Chem. Commun. (Camb). 1 (2006) 3311-3313. doi:10.1039/b604097g.

[34] C. Janáky, D. Hursán, B. Endrődi, W. Chanmanee, D. Roy, D. Liu, N.R. de Tacconi, B.H. Dennis, K. Rajeshwar, Electro- and Photoreduction of Carbon Dioxide: The Twain Shall Meet at Copper Oxide/Copper Interfaces, ACS Energy Lett. 1 (2016) 332-338. doi:10.1021/acsenergylett.6b00078.

[35] T. ITO, H. YAMAGUCHI, K. OKABE, T. MASUMI, Single-crystal growth and characterization of $\mathrm{Cu}_{2} \mathrm{O}$ and $\mathrm{CuO}$, J. Mater. Sci. 33 (1998) 3555-3566. doi:10.1023/A:1004690809547.

[36] X. Zhang, J. Song, J. Jiao, X. Mei, Preparation and photocatalytic activity of cuprous oxides, Solid State Sci. 12 (2010) 1215-1219. doi:10.1016/j.solidstatesciences.2010.03.009.

[37] M.D. Susman, Y. Feldman, A. Vaskevich, I. Rubinstein, Chemical Deposition of $\mathrm{Cu}_{2} \mathrm{O}$ Nanocrystals with Precise Morphology Control, ACS Nano. 8 (2014) 162174. doi:10.1021/nn405891g.

[38] S. Chen, L. Wang, Thermodynamic Oxidation and Reduction Potentials of Photocatalytic Semiconductors in Aqueous Solution, Chem. Mater. 24 (2012) 36593666. doi:10.1021/cm302533s. 
[39] C.G. Morales-Guio, S.D. Tilley, H. Vrubel, M. Grätzel, X. Hu, Hydrogen evolution from a copper(I) oxide photocathode coated with an amorphous molybdenum sulphide catalyst, Nat. Commun. 5 (2014) 1-7. doi:10.1038/ncomms4059.

[40] J. Choi, J.T. Song, H.S. Jang, M.-J. Choi, D.M. Sim, S. Yim, H. Lim, Y.S. Jung, J. $\mathrm{Oh}$, Interfacial band-edge engineered $\mathrm{TiO}_{2}$ protection layer on $\mathrm{Cu}_{2} \mathrm{O}$ photocathodes for efficient water reduction reaction, Electron. Mater. Lett. 13 (2017) 57-65. doi:10.1007/s13391-017-6316-1.

[41] T. Minami, Y. Nishi, T. Miyata, High-Efficiency $\mathrm{Cu}_{2} \mathrm{O}-\mathrm{Based}$ Heterojunction Solar Cells Fabricated Using a $\mathrm{Ga}_{2} \mathrm{O}_{3}$ Thin Film as N-Type Layer, Appl. Phys. Express. 6 (2013) 044101. doi:10.7567/APEX.6.044101.

[42] S. Piccinin, D. Rocca, M. Pastore, Role of Solvent in the Energy Level Alignment of Dye-Sensitized NiO Interfaces, J. Phys. Chem. C. 121 (2017) 22286-22294. doi:10.1021/acs.jpcc.7b08463.

[43] C. Hu, K. Chu, Y. Zhao, W.Y. Teoh, Efficient Photoelectrochemical Water Splitting over Anodized p -Type NiO Porous Films, ACS Appl. Mater. Interfaces. 6 (2014) 18558-18568. doi:10.1021/am507138b.

[44] M. Gong, W. Zhou, M.-C. Tsai, J. Zhou, M. Guan, M.-C. Lin, B. Zhang, Y. Hu, D.Y. Wang, J. Yang, S.J. Pennycook, B.-J. Hwang, H. Dai, Nanoscale nickel oxide/nickel heterostructures for active hydrogen evolution electrocatalysis, Nat. Commun. 5 (2014) 4695. doi:10.1038/ncomms5695.

[45] A.P. Amrute, Z. Łodziana, C. Mondelli, F. Krumeich, J. Pérez-Ramírez, Solid-State Chemistry of Cuprous Delafossites: Synthesis and Stability Aspects, Chem. Mater. 25 (2013) 4423-4435. doi:10.1021/cm402902m.

[46] D. Li, X. Fang, Z. Deng, S. Zhou, R. Tao, W. Dong, T. Wang, Y. Zhao, G. Meng, $\mathrm{X}$. Zhu, Electrical, optical and structural properties of $\mathrm{CuCrO}_{2}$ films prepared by pulsed laser deposition, J. Phys. D. Appl. Phys. 40 (2007) 4910-4915. doi:10.1088/0022-3727/40/16/023.

[47] M.S. Prévot, N. Guijarro, K. Sivula, Enhancing the Performance of a Robust SolGel-Processed p-Type Delafossite $\mathrm{CuFeO}_{2}$ Photocathode for Solar Water Reduction, ChemSusChem. 8 (2015) 1359-1367. doi:10.1002/cssc.201403146.

[48] A.K. Díaz-García, T. Lana-Villarreal, R. Gómez, Sol-gel copper chromium delafossite thin films as stable oxide photocathodes for water splitting, J. Mater. Chem. A. 3 (2015) 19683-19687. doi:10.1039/C5TA05227K.

[49] D. Xiong, Z. Xu, X. Zeng, W. Zhang, W. Chen, X. Xu, M. Wang, Y.-B. Cheng, Hydrothermal synthesis of ultrasmall $\mathrm{CuCrO}_{2}$ nanocrystal alternatives to $\mathrm{NiO}$ nanoparticles in efficient p-type dye-sensitized solar cells, J. Mater. Chem. 22 (2012) 24760. doi:10.1039/c2jm35101c.

[50] U. Kang, S.K. Choi, D.J. Ham, S.M. Ji, W. Choi, D.S. Han, A. Abdel-Wahab, H. Park, Photosynthesis of formate from $\mathrm{CO}_{2}$ and water at $1 \%$ energy efficiency via copper iron oxide catalysis, Energy Environ. Sci. 8 (2015) 2638-2643. doi:10.1039/C5EE01410G. 
[51] M.M.D. Ursu, S.K.I. Grozescu, Hexagonal polytype of $\mathrm{CuCrO}_{2}$ nanocrystals obtained by hydrothermal method, (2012) 2-9. doi:10.1007/s11051-012-1110-3.

[52] L. Huang, F. Peng, H. Yu, H. Wang, Preparation of cuprous oxides with different sizes and their behaviors of adsorption, visible-light driven photocatalysis and photocorrosion, Solid State Sci. $11 \quad$ (2009) 129-138. doi:10.1016/j.solidstatesciences.2008.04.013.

[53] Y. Yang, D. Xu, Q. Wu, P. Diao, $\mathrm{Cu}_{2} \mathrm{O} / \mathrm{CuO}$ Bilayered Composite as a HighEfficiency Photocathode for Photoelectrochemical Hydrogen Evolution Reaction, (2016) 1-13. doi:10.1038/srep35158.

[54] J. Gu, Y. Yan, J.W. Krizan, Q.D. Gibson, Z.M. Detweiler, R.J. Cava, A.B. Bocarsly, P-type $\mathrm{CuRhO}_{2}$ as a self-healing photoelectrode for water reduction under visible light, J. Am. Chem. Soc. 136 (2014) 830-833. doi:10.1021/ja408876k.

[55] H. Kawazoe, M. Yasukawa, H. Hyodo, M. Kurita, H. Yanagi, H. Hosono, P-type electrical conduction in transparent thin films of $\mathrm{CuAlO}_{2}$, Nature. 389 (1997) 939942. doi:10.1038/40087.

[56] R. Brahimi, M. Trari, A. Bouguelia, Y. Bessekhouad, Electrochemical intercalation of $\mathrm{O}^{2-}$ in $\mathrm{CuAlO}_{2}$ single crystal and photoelectrochemical properties, J. Solid State Electrochem. 14 (2009) 1333-1338. doi:10.1007/s10008-009-0935-x.

[57] S. Omeiri, B. Bellal, a. Bouguelia, Y. Bessekhouad, M. Trari, Electrochemical and photoelectrochemical characterization of $\mathrm{CuFeO}_{2}$ single crystal, J. Solid State Electrochem. 13 (2008) 1395-1401. doi:10.1007/s10008-008-0703-3.

[58] S. Bassaid, M. Chaib, S. Omeiri, a. Bouguelia, M. Trari, Photocatalytic reduction of cadmium over $\mathrm{CuFeO}_{2}$ synthesized by sol-gel, J. Photochem. Photobiol. A Chem. 201 (2009) 62-68. doi:10.1016/j.jphotochem.2008.09.015.

[59] M.S. Prévot, X.A. Jeanbourquin, W.S. Bourée, F. Abdi, D. Friedrich, R. van de Krol, N. Guijarro, F. Le Formal, K. Sivula, Evaluating Charge Carrier Transport and Surface States in $\mathrm{CuFeO}_{2}$ Photocathodes, Chem. Mater. 29 (2017) 4952-4962. doi:10.1021/acs.chemmater.7b01284.

[60] M.A. Sarabia, S.D. Rojas, Z. López-cabaña, R. Villalba, G. González, A.L. Cabrera, Journal of Physics and Chemistry of Solids Carbon dioxide adsorption studies on delafossite $\mathrm{CuFeO}_{2}$ hydrothermally synthesized, J. Phys. Chem. Solids. 98 (2016) 271-279. doi:10.1016/j.jpcs.2016.07.013.

[61] X. Yang, E.A. Fugate, Y. Mueanngern, L.R. Baker, Photoelectrochemical $\mathrm{CO}_{2}$ Reduction to Acetate on Iron-Copper Oxide Catalysts, ACS Catal. 7 (2017) 177180. doi:10.1021/acscatal.6b02984.

[62] J. Gu, A. Wuttig, J.W. Krizan, Y. Hu, Z.M. Detweiler, R.J. Cava, A.B. Bocarsly, $\mathrm{Mg}$-Doped $\mathrm{CuFeO}_{2}$ Photocathodes for Photoelectrochemical Reduction of Carbon Dioxide, J. Phys. Chem. C. 117 (2013) 12415-12422. doi:10.1021/jp402007z. 
[63] A. Wuttig, J.W. Krizan, J. Gu, J.J. Frick, R.J. Cava, A.B. Bocarsly, The effect of $\mathrm{Mg}$-doping and $\mathrm{Cu}$ nonstoichiometry on the photoelectrochemical response of $\mathrm{CuFeO}_{2}$, J. Mater. Chem. A. 5 (2017) 165-171. doi:10.1039/C6TA06504J.

[64] S. Song, D. Kim, H.M. Jang, B.C. Yeo, S.S. Han, C.S. Kim, J.F. Scott, $\beta-\mathrm{CuGaO}_{2}$ as a Strong Candidate Material for Efficient Ferroelectric Photovoltaics, Chem. Mater. 29 (2017) 7596-7603. doi:10.1021/acs.chemmater.7b03141.

[65] W.A. Dunlap-Shohl, T.B. Daunis, X. Wang, J. Wang, B. Zhang, D. Barrera, Y. Yan, J.W.P. Hsu, D.B. Mitzi, Room-temperature fabrication of a delafossite $\mathrm{CuCrO}_{2}$ hole transport layer for perovskite solar cells, J. Mater. Chem. A. 6 (2018) 469-477. doi:10.1039/C7TA09494A.

[66] Y. Ma, X. Zhou, Q. Ma, A. Litke, P. Liu, Y. Zhang, C. Li, E.J.M. Hensen, Photoelectrochemical Properties of $\mathrm{CuCrO}_{2}$ : Characterization of Light Absorption and Photocatalytic H2 Production Performance, Catal. Letters. 144 (2014) 1487-1493. doi:10.1007/s10562-014-1318-1.

[67] W. Ketir, a. Bouguelia, M. Trari, Photocatalytic removal of $\mathrm{M}^{2+}\left(\mathrm{Ni}^{2+}, \mathrm{Cu}^{2+}, \mathrm{Zn}^{2+}\right.$, $\mathrm{Cd}^{2+}, \mathrm{Hg}^{2+}$ and $\mathrm{Ag}^{+}$) over new catalyst $\mathrm{CuCrO}_{2}$, J. Hazard. Mater. 158 (2008) 257-263. doi:10.1016/j.jhazmat.2008.01.074.

[68] A.P. Amrute, G.O. Larrazábal, C. Mondelli, J. Pérez-Ramírez, $\mathrm{CuCrO}_{2}$ delafossite: A stable copper catalyst for chlorine production, Angew. Chemie - Int. Ed. 52 (2013) 9772-9775. doi:10.1002/anie.201304254.

[69] K. Rajeshwar, N.R. de Tacconi, G. Ghadimkhani, W. Chanmanee, C. Janáky, Tailoring copper oxide semiconductor nanorod arrays for photoelectrochemical reduction of carbon dioxide to methanol., Chemphyschem. 14 (2013) 2251-2259. doi:10.1002/cphc.201300080.

[70] M.S. Prévot, Y. Li, N. Guijarro, K. Sivula, Improving charge collection with delafossite photocathodes: a host-guest $\mathrm{CuAlO}_{2} / \mathrm{CuFeO}_{2}$ approach, J. Mater. Chem. A. 4 (2016) 3018-3026. doi:10.1039/C5TA06336A.

[71] U. Kang, H. Park, A facile synthesis of $\mathrm{CuFeO}_{2}$ and $\mathrm{CuO}$ composite photocatalyst fi lms for the production of liquid formate from $\mathrm{CO}_{2}$ and water over a month $\uparrow, \mathrm{J}$. Mater. Chem. A Mater. Energy Sustain. 5 (2017) 2123-2131. doi:10.1039/C6TA09378G.

[72] C.G. Read, Y. Park, K.-S. Choi, Electrochemical Synthesis of p-Type $\mathrm{CuFeO}_{2}$ Electrodes for Use in a Photoelectrochemical Cell, J. Phys. Chem. Lett. 3 (2012) 1872-1876. doi:10.1021/jz300709t.

[73] S.Y. Choi, C.-D. Kim, D.S. Han, H. Park, Facilitating hole transfer on electrochemically synthesized p-type $\mathrm{CuAlO}_{2}$ films for efficient solar hydrogen production from water, J. Mater. Chem. A. 5 (2017) 10165-10172. doi:10.1039/C7TA01919J.

[74] P.P. Sahoo, B. Zoellner, P.A. Maggard, Optical, electronic, and photoelectrochemical properties of the p-type $\mathrm{Cu}_{3-\mathrm{x}} \mathrm{VO}_{4}$ semiconductor, J. Mater. Chem. A. 3 (2015) 4501-4509. doi:10.1039/C4TA04876H. 
[75] A. Kormányos, A. Thomas, M.N. Huda, P. Sarker, J.P. Liu, N. Poudyal, C. Janáky, K. Rajeshwar, Solution Combustion Synthesis, Characterization, and Photoelectrochemistry of $\mathrm{CuNb}_{2} \mathrm{O}_{6}$ and $\mathrm{ZnNb}_{2} \mathrm{O}_{6}$ Nanoparticles, J. Phys. Chem. C. 120 (2016) 16024-16034. doi:10.1021/acs.jpcc.5b12738.

[76] N. King, I. Sullivan, P. Watkins-Curry, J.Y. Chan, P.A. Maggard, Flux-mediated syntheses, structural characterization and low-temperature polymorphism of the ptype semiconductor $\mathrm{Cu}_{2} \mathrm{Ta}_{4} \mathrm{O}_{11}$, J. Solid State Chem. 236 (2016) 10-18. doi:10.1016/j.jssc.2015.08.041.

[77] C.G. Morales-Guio, L.-A. Stern, X. Hu, Nanostructured hydrotreating catalysts for electrochemical hydrogen evolution, Chem. Soc. Rev. 43 (2014) 6555. doi:10.1039/C3CS60468C.

[78] I.C. Man, H.-Y. Su, F. Calle-Vallejo, H.A. Hansen, J.I. Martínez, N.G. Inoglu, J. Kitchin, T.F. Jaramillo, J.K. Nørskov, J. Rossmeisl, Universality in Oxygen Evolution Electrocatalysis on Oxide Surfaces, ChemCatChem. 3 (2011) 1159-1165. doi:10.1002/cctc.201000397.

[79] J. Li, N. Wu, Semiconductor-based photocatalysts and photoelectrochemical cells for solar fuel generation: a review, Catal. Sci. Technol. 5 (2015) 1360-1384. doi:10.1039/C4CY00974F.

[80] P. V Kamat, Manipulation of Charge Transfer Across Semiconductor Interface. A Criterion That Cannot Be Ignored in Photocatalyst Design, J. Phys. Chem. Lett. 3 (2012) 663-672. doi:10.1021/jz201629p.

[81] W.-J. Chun, A. Ishikawa, H. Fujisawa, T. Takata, J.N. Kondo, M. Hara, M. Kawai, Y. Matsumoto, K. Domen, Conduction and Valence Band Positions of $\mathrm{Ta}_{2} \mathrm{O}_{5}$, TaON, and $\mathrm{Ta}_{3} \mathrm{~N}_{5}$ by UPS and Electrochemical Methods, J. Phys. Chem. B. 107 (2003) 1798-1803. doi:10.1021/jp027593f.

[82] Y. Xu, W. Zhao, R. Xu, Y. Shi, B. Zhang, Synthesis of ultrathin CdS nanosheets as efficient visible-light-driven water splitting photocatalysts for hydrogen evolution, Chem. Commun. 49 (2013) 9803. doi:10.1039/c3cc46342g.

[83] X. Li, X. Hao, A. Abudula, G. Guan, Nanostructured catalysts for electrochemical water splitting: current state and prospects, J. Mater. Chem. A. 4 (2016) 1197312000. doi:10.1039/C6TA02334G.

[84] Y.-X. Yu, L. Pan, M.-K. Son, M.T. Mayer, W.-D. Zhang, A. Hagfeldt, J. Luo, M. Grätzel, Solution-Processed $\mathrm{Cu}_{2} \mathrm{~S}$ Photocathodes for Photoelectrochemical Water Splitting, ACS Energy Lett. 3 (2018) 760-766. doi:10.1021/acsenergylett.7b01326.

[85] Y. Sun, Z. Sun, S. Gao, H. Cheng, Q. Liu, F. Lei, S. Wei, Y. Xie, All-SurfaceAtomic-Metal Chalcogenide Sheets for High-Efficiency Visible-Light Photoelectrochemical Water Splitting, Adv. Energy Mater. 4 (2014) 1300611. doi:10.1002/aenm.201300611.

[86] F.E. Osterloh, Inorganic nanostructures for photoelectrochemical and photocatalytic water splitting, Chem. Soc. Rev. 42 (2013) 2294-2320. doi:10.1039/C2CS35266D. 
[87] I. Robel, M. Kuno, P. V. Kamat, Size-dependent electron injection from excited CdSe quantum dots into $\mathrm{TiO}_{2}$ nanoparticles, J. Am. Chem. Soc. 129 (2007) 41364137. doi:10.1021/ja070099a.

[88] A. Ishikawa, T. Takata, J.N. Kondo, M. Hara, H. Kobayashi, K. Domen, Oxysulfide $\mathrm{Sm}_{2} \mathrm{Ti}_{2} \mathrm{~S}_{2} \mathrm{O}_{5}$ as a Stable Photocatalyst for Water Oxidation and Reduction under Visible Light Irradiation $(\lambda \leq 650 \mathrm{~nm})$, J. Am. Chem. Soc. 124 (2002) 1354713553. doi:10.1021/ja0269643.

[89] M. Hara, J. Nunoshige, T. Takata, J.N. Kondo, K. Domen, Unusual enhancement of $\mathrm{H}_{2}$ evolution by $\mathrm{Ru}$ on $\mathrm{TaON}$ photocatalyst under visible light irradiation, Chem. Commun. (2003) 3000. doi:10.1039/b309935k.

[90] Y. Lee, K. Nukumizu, T. Watanabe, T. Takata, M. Hara, M. Yoshimura, K. Domen, Effect of $10 \mathrm{MPa}$ Ammonia Treatment on the Activity of Visible Light Responsive $\mathrm{Ta}_{3} \mathrm{~N}_{5}$ Photocatalyst, Chem. Lett. 35 (2006) 352-353. doi:10.1246/cl.2006.352.

[91] K. Maeda, K. Domen, New Non-Oxide Photocatalysts Designed for Overall Water Splitting under Visible Light, J. Phys. Chem. C. 111 (2007) 7851-7861. doi:10.1021/jp070911w.

[92] T. Zhu, M.N. Chong, E.S. Chan, Nanostructured tungsten trioxide thin films synthesized for photoelectrocatalytic water oxidation: A review, ChemSusChem. 7 (2014) 2974-2997. doi:10.1002/cssc.201402089.

[93] H. Tsuchiya, J.M. Macak, I. Sieber, L. Taveira, A. Ghicov, K. Sirotna, P. Schmuki, Self-organized porous $\mathrm{WO}_{3}$ formed in NaF electrolytes, Electrochem. Commun. 7 (2005) 295-298. doi:10.1016/j.elecom.2005.01.003.

[94] W. Lee, K. Schwirn, M. Steinhart, E. Pippel, R. Scholz, U. Gösele, Structural engineering of nanoporous anodic aluminium oxide by pulse anodization of aluminium, Nat. Nanotechnol. 3 (2008) 234-239. doi:10.1038/nnano.2008.54.

[95] J. Chen, J. Xu, S. Zhou, N. Zhao, C. Wong, Facile and scalable fabrication of threedimensional $\mathrm{Cu}(\mathrm{OH})_{2}$ nanoporous nanorods for solid-state supercapacitors, J. Mater. Chem. A. 3 (2015) 17385-17391. doi:10.1039/C5TA04164C.

[96] S.K. Shinde, D.P. Dubal, G.S. Ghodake, D.Y. Kim, V.J. Fulari, Nanoflower-like $\mathrm{CuO} / \mathrm{Cu}(\mathrm{OH})_{2}$ hybrid thin films: Synthesis and electrochemical supercapacitive properties, J. Electroanal. Chem. 732 (2014) 80-85. doi:10.1016/j.jelechem.2014.09.004.

[97] C. Ajay Kushwaha, Roozbeh S. Moakhara, G.K.L. Goha, Goutam K. Dalapatia, Morphologically tailored $\mathrm{CuO}$ photocathode using aqueous solution technique for enhanced visible light driven water splitting, Journal Photochem. Photobiol. A Chem. 337 (2017) 54-61. doi:10.1016/j.jphotochem.2017.01.014.

[98] N. Mukherjee, M. Paulose, O.K. Varghese, G.K. Mor, C. a. Grimes, Fabrication of nanoporous tungsten oxide by galvanostatic anodization, J. Mater. Res. 18 (2003) 2296-2299. doi:10.1557/JMR.2003.0321. 
[99] A. Watcharenwong, W. Chanmanee, N.R. de Tacconi, C.R. Chenthamarakshan, P. Kajitvichyanukul, K. Rajeshwar, Anodic growth of nanoporous $\mathrm{WO}_{3}$ films: Morphology, photoelectrochemical response and photocatalytic activity for methylene blue and hexavalent chrome conversion, J. Electroanal. Chem. 612 (2008) 112-120. doi:10.1016/j.jelechem.2007.09.030.

[100] N.K. Allam, C.A. Grimes, Electrochemical fabrication of complex copper oxide nanoarchitectures via copper anodization in aqueous and non-aqueous electrolytes, Mater. Lett. 65 (2011) 1949-1955. doi:10.1016/j.matlet.2011.03.105.

[101] P. Roy, S. Berger, P. Schmuki, $\mathrm{TiO}_{2}$ nanotubes: Synthesis and applications, Angew. Chemie - Int. Ed. 50 (2011) 2904-2939. doi:10.1002/anie.201001374.

[102] J.M. Macák, H. Tsuchiya, P. Schmuki, High-Aspect-Ratio $\mathrm{TiO}_{2}$ Nanotubes by Anodization of Titanium, Angew. Chemie Int. Ed. 44 (2005) 2100-2102. doi:10.1002/anie.200462459.

[103] D. Regonini, C.R. Bowen, A. Jaroenworaluck, R. Stevens, A review of growth mechanism, structure and crystallinity of anodized $\mathrm{TiO}_{2}$ nanotubes, Mater. Sci. Eng. R Reports. 74 (2013) 377-406. doi:10.1016/j.mser.2013.10.001.

[104] H. Wang, A. Sapi, C.M. Thompson, F. Liu, D. Zherebetskyy, J.M. Krier, L.M. Carl, X. Cai, L.-W. Wang, G.A. Somorjai, Dramatically Different Kinetics and Mechanism at Solid/Liquid and Solid/Gas Interfaces for Catalytic Isopropanol Oxidation over Size-Controlled Platinum Nanoparticles, J. Am. Chem. Soc. 136 (2014) 10515-10520. doi:10.1021/ja505641r.

[105] K. Rajeshwar, N.R. de Tacconi, Solution combustion synthesis of oxide semiconductors for solar energy conversion and environmental remediation, Chem. Soc. Rev. 38 (2009) 1984-1998. doi:10.1039/b811238j.

[106] F. Li, J. Ran, M. Jaroniec, S.Z. Qiao, Solution combustion synthesis of metal oxide nanomaterials for energy storage and conversion, Nanoscale. 7 (2015) 17590-17610. doi:10.1039/C5NR05299H.

[107] A. Varma, A.S. Mukasyan, A.S. Rogachev, K. V. Manukyan, Solution Combustion Synthesis of Nanoscale Materials, Chem. Rev. 116 (2016) 14493-14586. doi:10.1021/acs.chemrev.6b00279.

[108] J.J. Kingsley, K.C. Patil, A novel combustion process for the synthesis of fine particle $\alpha$-alumina and related oxide materials, Mater. Lett. 6 (1988) 427-432. doi:10.1016/0167-577X(88)90045-6.

[109] J. Zhang, Q. Guo, Y. Liu, Y. Cheng, Preparation and Characterization of $\mathrm{Fe}_{2} \mathrm{O}_{3}$ $/ \mathrm{Al}_{2} \mathrm{O}_{3}$ Using the Solution Combustion Approach for Chemical Looping Combustion, Ind. Eng. Chem. Res. 51 (2012) 12773-12781. doi:10.1021/ie301804c.

[110] P. Erri, P. Pranda, A. Varma, Oxidizer-Fuel Interactions in Aqueous Combustion Synthesis. 1. Iron(III) Nitrate-Model Fuels, Ind. Eng. Chem. Res. 43 (2004) 3092-3096. doi:10.1021/ie030822f.

[111] S.L. González-Cortés, F.E. Imbert, Fundamentals, properties and applications of solid catalysts prepared by solution combustion synthesis (SCS), Appl. Catal. A Gen. 452 (2013) 117-131. doi:10.1016/j.apcata.2012.11.024. 
[112] F. Deganello, G. Marcì, G. Deganello, Citrate-nitrate auto-combustion synthesis of perovskite-type nanopowders: A systematic approach, J. Eur. Ceram. Soc. 29 (2009) 439-450. doi:10.1016/j.jeurceramsoc.2008.06.012.

[113] T.W. Chiu, B.S. Yu, Y.R. Wang, K. Te Chen, Y. Te Lin, Synthesis of nanosized $\mathrm{CuCrO}_{2}$ porous powders via a self-combustion glycine nitrate process, J. Alloys Compd. 509 (2011) 2933-2935. doi:10.1016/j.jallcom.2010.11.162.

[114] K. Nagaveni, M.S. Hegde, N. Ravishankar, G.N. Subbanna, G. Madras, Synthesis and Structure of Nanocrystalline $\mathrm{TiO}_{2}$ with Lower Band Gap Showing High Photocatalytic Activity, Langmuir. 20 (2004) 2900-2907. doi:10.1021/la035777v.

[115] A. MURPHY, Band-gap determination from diffuse reflectance measurements of semiconductor films, and application to photoelectrochemical water-splitting, Sol. Energy Mater. Sol. Cells. 91 (2007) 1326-1337. doi:10.1016/j.solmat.2007.05.005.

[116] E.L. Simmons, Diffuse reflectance spectroscopy: a comparison of the theories, Appl. Opt. 14 (1975) 1380. doi:10.1364/AO.14.001380.

[117] K.S. Waseda Yoshio, Matsubara Eiichiro, X-Ray Diffraction Crystallography, 2011. doi:10.1007/978-3-642-16635-8.

[118] A.C. Larson, R.B. Von Dreele, General Structure Analysis System (GSAS), Los Alamos Natl. Lab. Rep. (2004) 86-748.

[119] B.H. Toby, EXPGUI , a graphical user interface for GSAS, J. Appl. Crystallogr. 34 (2001) 210-213. doi:10.1107/S0021889801002242.

[120] Z. Chen, T.G. Deutsch, H.N. Dinh, K. Domen, K. Emery, A.J. Forman, N. Gaillard, R. Garland, C. Heske, T.F. Jaramillo, A. Kleiman-Shwarsctein, E. Miller, K. Takanabe, J. Turner, Photoelectrochemical Water Splitting, Springer, 2013. doi:10.1007/978-1-4614-8298-7_1.

[121] N.K. Shrestha, M. Yang, P. Schmuki, Self-Ordered Nanoporous Nickel Oxide/Fluoride Composite Film with Strong Electrochromic Contrast, Electrochem. Solid-State Lett. 13 (2010) C21. doi:10.1149/1.3430656.

[122] G.F. Samu, K. Pencz, C. Janáky, K. Rajeshwar, On the electrochemical synthesis and charge storage properties of $\mathrm{WO}_{3}$ /polyaniline hybrid nanostructures, J. Solid State Electrochem. 19 (2015) 2741-2751. doi:10.1007/s10008-015-2820-0.

[123] J.M. Macak, H. Hildebrand, U. Marten-Jahns, P. Schmuki, Mechanistic aspects and growth of large diameter self-organized $\mathrm{TiO}_{2}$ nanotubes, J. Electroanal. Chem. 621 (2008) 254-266. doi:10.1016/j.jelechem.2008.01.005.

[124] G. Zhou, D.-W. Wang, L.-C. Yin, N. Li, F. Li, H.-M. Cheng, Oxygen Bridges between $\mathrm{NiO}$ Nanosheets and Graphene for Improvement of Lithium Storage, ACS Nano. 6 (2012) 3214-3223. doi:10.1021/nn300098m.

[125] A.G. Marrani, V. Novelli, S. Sheehan, D.P. Dowling, D. Dini, Probing the Redox States at the Surface of Electroactive Nanoporous NiO Thin Films, ACS Appl. Mater. Interfaces. 6 (2014) 143-152. doi:10.1021/am403671h. 
[126] H. Bode, K. Dehmelt, J. Witte, Zur kenntnis der nickelhydroxidelektrode-I.Über das nickel (II)-hydroxidhydrat, Electrochim. Acta. 11 (1966) 1079-IN1. doi:10.1016/0013-4686(66)80045-2.

[127] B.A. Nail, J.M. Fields, J. Zhao, J. Wang, M.J. Greaney, R.L. Brutchey, F.E. Osterloh, Nickel Oxide Particles Catalyze Photochemical Hydrogen Evolution from Water-Nanoscaling Promotes P-Type Character and Minority Carrier Extraction, ACS Nano. 9 (2015) 5135-5142. doi:10.1021/acsnano.5b00435.

[128] E.L. Ratcliff, J. Meyer, K.X. Steirer, A. Garcia, J.J. Berry, D.S. Ginley, D.C. Olson, A. Kahn, N.R. Armstrong, Evidence for near-Surface NiOOH Species in SolutionProcessed $\mathrm{NiO}_{\mathrm{x}}$ Selective Interlayer Materials: Impact on Energetics and the Performance of Polymer Bulk Heterojunction Photovoltaics, Chem. Mater. 23 (2011) 4988-5000. doi:10.1021/cm202296p.

[129] M.C. Biesinger, B.P. Payne, L.W.M. Lau, A. Gerson, R.S.C. Smart, X-ray photoelectron spectroscopic chemical state quantification of mixed nickel metal, oxide and hydroxide systems, Surf. Interface Anal. 41 (2009) 324-332. doi:10.1002/sia.3026.

[130] M.C. Biesinger, B.P. Payne, A.P. Grosvenor, L.W.M. Lau, A.R. Gerson, R.S.C. Smart, Resolving surface chemical states in XPS analysis of first row transition metals, oxides and hydroxides: Cr, Mn, Fe, Co and Ni, Appl. Surf. Sci. 257 (2011) 2717-2730. doi:10.1016/j.apsusc.2010.10.051.

[131] Y. Sun, Y. Wang, J.S. Pan, L. Wang, C.Q. Sun, Elucidating the 4f Binding Energy of an Isolated Pt Atom and Its Bulk Shift from the Measured Surface- and SizeInduced Pt 4f Core Level Shift, J. Phys. Chem. C. 113 (2009) 14696-14701. doi:10.1021/jp904445a.

[132] J.Z. Shyu, K. Otto, Identification of platinum phases on $\gamma$-alumina by XPS, Appl. Surf. Sci. 32 (1988) 246-252. doi:10.1016/0169-4332(88)90085-2.

[133] B. Beverskog, I. Puigdomenech, Revised Pourbaix diagrams for nickel at 25-300 ${ }^{\circ}$ C, Corros. Sci. 39 (1997) 969-980. doi:10.1016/S0010-938X(97)00002-4.

[134] M. Arenz, K.J.J. Mayrhofer, V. Stamenkovic, B.B. Blizanac, T. Tomoyuki, P.N. Ross, N.M. Markovic, The Effect of the Particle Size on the Kinetics of CO Electrooxidation on High Surface Area Pt Catalysts, J. Am. Chem. Soc. 127 (2005) 6819-6829. doi:10.1021/ja043602h.

[135] K.J.J. Mayrhofer, B.B. Blizanac, M. Arenz, V.R. Stamenkovic, P.N. Ross, N.M. Markovic, The Impact of Geometric and Surface Electronic Properties of PtCatalysts on the Particle Size Effect in Electrocatalysis, J. Phys. Chem. B. 109 (2005) 14433-14440. doi:10.1021/jp051735z.

[136] M. Shao, A. Peles, K. Shoemaker, Electrocatalysis on Platinum Nanoparticles: Particle Size Effect on Oxygen Reduction Reaction Activity, Nano Lett. 11 (2011) 3714-3719. 
[137] A. Sapi, F. Liu, X. Cai, C.M. Thompson, H. Wang, K. An, J.M. Krier, G.A. Somorjai, Comparing the Catalytic Oxidation of Ethanol at the Solid-Gas and Solid-Liquid Interfaces over Size-Controlled Pt Nanoparticles: Striking Differences in Kinetics and Mechanism, Nano Lett. 14 (2014) 6727-6730. doi:10.1021/nl5035545.

[138] H. Wang, Y. Wang, Z. Zhu, A. Sapi, K. An, G. Kennedy, W.D. Michalak, G.A. Somorjai, Influence of size-induced oxidation state of platinum nanoparticles on selectivity and activity in catalytic methanol oxidation in the Gas phase, Nano Lett. 13 (2013) 2976-2979. doi:10.1021/n1401568x.

[139] V. V. Pushkarev, K. An, S. Alayoglu, S.K. Beaumont, G.A. Somorjai, Hydrogenation of benzene and toluene over size controlled Pt/SBA-15 catalysts: Elucidation of the Pt particle size effect on reaction kinetics, J. Catal. 292 (2012) 64-72. doi:10.1016/j.jcat.2012.04.022.

[140] S.A. Ali Yahia, L. Hamadou, A. Kadri, N. Benbrahim, E.M.M. Sutter, Effect of Anodizing Potential on the Formation and EIS Characteristics of $\mathrm{TiO}_{2}$ Nanotube Arrays, J. Electrochem. Soc. 159 (2012) K83. doi:10.1149/2.077204jes.

[141] A.S. Mukasyan, P. Epstein, P. Dinka, Solution combustion synthesis of nanomaterials, Proc. Combust. Inst. 31 II (2007) 1789-1795. doi:10.1016/j.proci.2006.07.052.

[142] O. Crottaz, Preparation of Trigonal and Hexagonal Cuprous Chromite and Phase Transition Study Based on Single Crystal Structure Data, J. Solid State Chem. 122 (1996) 247-250. doi:10.1006/jssc.1996.0109.

[143] D. Roy, G.F. Samu, M.K. Hossain, C. Janáky, K. Rajeshwar, On the measured optical bandgap values of inorganic oxide semiconductors for solar fuels generation, Catal. Today. (2017) 1-9. doi:10.1016/j.cattod.2017.03.016.

[144] L.M. Alrehaily, J.M. Joseph, A.Y. Musa, D.A. Guzonas, J.C. Wren, Gammaradiation induced formation of chromium oxide nanoparticles from dissolved dichromate, Phys. Chem. Chem. Phys. 15 (2013) 98-107. doi:10.1039/C2CP43150E.

[145] O. Aktas, K.D. Truong, T. Otani, G. Balakrishnan, M.J. Clouter, T. Kimura, G. Quirion, Raman scattering study of delafossite magnetoelectric multiferroic compounds: $\mathrm{CuFeO}_{2}$ and $\mathrm{CuCrO}_{2}$, J. Phys. Condens. Matter. 24 (2012) 036003,1-7. doi:10.1088/0953-8984/24/3/036003.

[146] A.B. Garg, A.K. Mishra, K.K. Pandey, S.M. Sharma, Multiferroic $\mathrm{CuCrO}_{2}$ under high pressure: In situ X-ray diffraction and Raman spectroscopic studies, J. Appl. Phys. 116 (2014) 133514-1-8. doi:10.1063/1.4896952.

[147] M. Hosseini-Sarvari, F. Moeini, Nano copper(i) oxide/zinc oxide catalyzed Narylation of nitrogen-containing heterocycles with aryl halides and arylboronic acids in air, RSC Adv. 4 (2014) 7321-7329. doi:10.1039/c3ra46548a.

[148] D. Ursu, M. Miclau, Thermal stability of nanocrystalline $3 \mathrm{R}-\mathrm{CuCrO}_{2}, \mathrm{~J}$. Nanoparticle Res. 16 (2014) 2160 (1-7). doi:10.1007/s11051-013-2160-x. 
[149] E. Kecsenovity, B. Endrodi, Z. Pápa, K. Hernadi, K. Rajeshwar, C. Janaky, Ultralong carbon nanotubes decorated with $\mathrm{Cu}_{2} \mathrm{O}$ nanocrystals: a hybrid platform for enhanced photoelectrochemical $\mathrm{CO}_{2}$ reduction, J. Mater. Chem. A. 4 (2016) 3139-3147. doi:10.1039/C5TA10457B.

[150] E. Kecsenovity, B. Endrődi, P.S. Tóth, Y. Zou, R.A.W. Dryfe, K. Rajeshwar, C. Janáky, Enhanced Photoelectrochemical Performance of Cuprous Oxide/Graphene Nanohybrids, J. Am. Chem. Soc. 139 (2017) 6682-6692. doi:10.1021/jacs.7b01820.

[151] A. Paracchino, V. Laporte, K. Sivula, M. Grätzel, E. Thimsen, Highly active oxide photocathode for photoelectrochemical water reduction, Nat. Mater. 10 (2011) 456461. doi:10.1038/nmat3017.

[152] A. Paracchino, N. Mathews, T. Hisatomi, M. Stefik, S.D. Tilley, M. Grätzel, Ultrathin films on copper(i) oxide water splitting photocathodes: a study on performance and stability, Energy Environ. Sci. 5 (2012) 8673-8681. doi:10.1039/c2ee22063f.

[153] R. Chen, C. Yang, W. Cai, H.-Y. Wang, J. Miao, L. Zhang, S. Chen, B. Liu, Use of Platinum as the Counter Electrode to Study the Activity of Nonprecious Metal Catalysts for the Hydrogen Evolution Reaction, ACS Energy Lett. 2 (2017) 10701075. doi:10.1021/acsenergylett.7b00219.

[154] T.-W. Chiu, P.-S. Huang, Preparation of delafossite $\mathrm{CuFeO}_{2}$ coral-like powder using a self-combustion glycine nitrate process, Ceram. Int. 39 (2013) 575-578. doi:10.1016/j.ceramint.2012.10.138.

[155] M. Lalanne, A. Barnabé, F. Mathieu, P. Tailhades, Synthesis and Thermostructural Studies of a $\mathrm{CuFe}_{1-\mathrm{x}} \mathrm{Cr}_{\mathrm{x}} \mathrm{O}_{2}$ Delafossite Solid Solution with $0 \leq \mathrm{x} \leq 1$, Inorg. Chem. 48 (2009) 6065-6071. doi:10.1021/ic900437x.

[156] A.R. Denton, N.W. Ashcroft, Vegard's law, Phys. Rev. A. 43 (1991) 3161-3164. doi:10.1103/PhysRevA.43.3161. 


\section{Köszönetnyilvánítás}

Ezúton szeretnék köszönetet mondani Dr. Tóth Ágotának a Fizikai Kémiai és Anyagtudományi Tanszék vetőjének, amiért lehetővé tette számomra, hogy a tanszéken végezhessem doktori munkámat.

Szeretném megköszönni témavezetőmnek, Dr. Janáky Csabának, hogy lehetőséget biztosított, hogy ebben a kutatócsoportban készíthessem el a doktori munkámat, valamint, hogy kérdéseimmel mindig bátran fordulhattam hozzá.

Köszönöm Dr. Visy Csaba emeritus professzornak, hogy bebocsátást adott a hajdani Elektrokémia kutatócsoportba, ahol elkezdtem pályafutásom.

Szeretném, megköszöni Dr. Sápi Andrásnak, az SZTE Alkalmazott és Környezeti Kémiai Tanszék adjunktusának, hogy együttmüködésünk során rendelkezésemre bocsátotta a $\mathrm{Pt}$ nanorészecskéket.

Továbbá szeretném megköszönni Dr. Samu Gergelynek, hogy munkám során mindig bátorított és sok más segítség mellett segített a Rietvield felbontások elkészítésében.

Továbbá szeretném megköszönni Dr. Endrődi Balázsnak, Dr. Kormányos Attilának, Hursán Dorottyának valamint Takács Bettinának, hogy segítettek munkám során valamint, mindig jó kedvel tudtam betenni a lábam a laborba.

Köszönöm Dr. Lazányi Istvánnak, hogy segített lektorálni a disszertációmat korai szakaszában.

Végül szeretném megköszönni páromnak, Mesterházy Editnek valamint családomnak és barátaimnak, hogy mindvégig bátorítottak még a legnehezebb időszakokban is. 